Prepared in cooperation with the Gary Sanitary District, the Lake Michigan Coastal Program, the U.S. Army Corps of Engineers, and the National Park Service

\title{
Hydrologic Data and Groundwater Flow Simulations in the Vicinity of Long Lake, Indiana Dunes National Lakeshore, Near Gary, Indiana
}

Scientific Investigations Report 2013-5003 


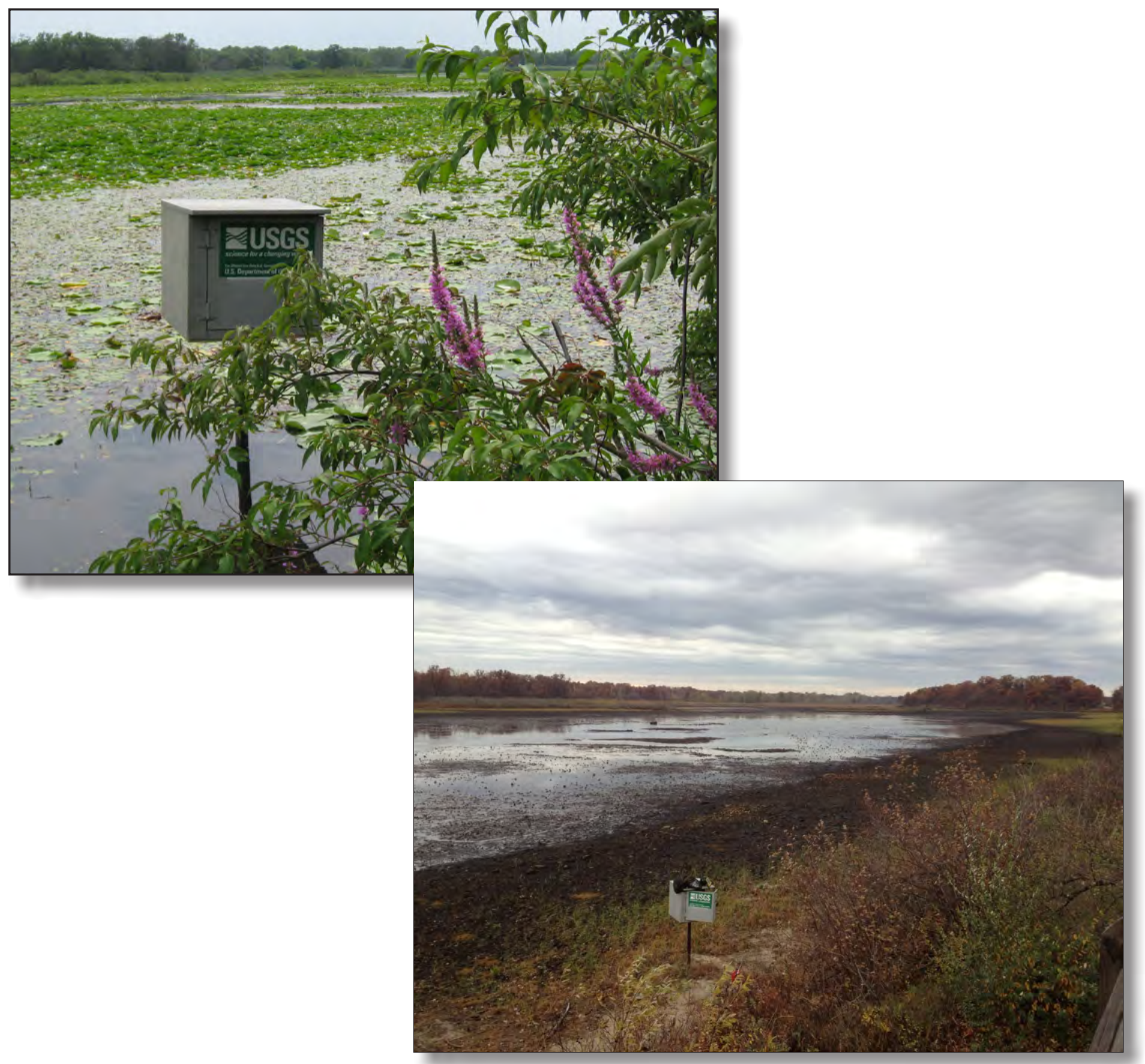

Cover background map modified from U.S. Army Corps of Engineers, 1902, Map showing Calumet River district, III. \& Ind.: 1 sheet.

Photos this page: (top) East Long Lake and USGS well E-3 (USGS 413702087123301) taken on July 19, 2010, by David C. Lampe; (bottom) East Long Lake and USGS well E-3 taken on November 2, 2012, by David C. Lampe. 


\section{Hydrologic Data and Groundwater Flow Simulations in the Vicinity of Long Lake, Indiana Dunes National Lakeshore, Near Gary, Indiana}

By David C. Lampe and E. Randall Bayless

Prepared in cooperation with the Gary Sanitary District, the Lake Michigan Coastal Program, the U.S. Army Corps of Engineers, and the National Park Service

Scientific Investigations Report 2013-5003 


\section{U.S. Department of the Interior \\ KEN SALAZAR, Secretary}

\section{U.S. Geological Survey \\ Suzette M. Kimball, Acting Director}

U.S. Geological Survey, Reston, Virginia: 2013

For more information on the USGS - the Federal source for science about the Earth, its natural and living resources, natural hazards, and the environment, visit http://www.usgs.gov or call 1-888-ASK-USGS.

For an overview of USGS information products, including maps, imagery, and publications, visit http://www.usgs.gov/pubprod

To order this and other USGS information products, visit http://store.usgs.gov

Any use of trade, product, or firm names is for descriptive purposes only and does not imply endorsement by the U.S. Government.

Although this report is in the public domain, permission must be secured from the individual copyright owners to reproduce any copyrighted materials contained within this report.

Suggested citation:

Lampe, D.C., and Bayless, E.R., 2013, Hydrologic data and groundwater flow simulations in the vicinity of Long Lake, Indiana Dunes National Lakeshore, near Gary, Indiana: U.S. Geological Survey Scientific Investigations Report 2012-5003, $96 \mathrm{p}$. 


\section{Acknowledgments}

This project was supported by the Gary Sanitary District, the Indiana Lake Michigan Coastal Grants Program, the National Park Service-U.S. Geological Survey-Water Quality Partnership program, and the U.S. Army Corps of Engineers.

The authors and the U.S. Geological Survey gratefully acknowledge the contributions of many persons to this study. Vernetta White of the Gary Sanitary District, Jennifer Orsburn of the Indiana Department of Natural Resources, Lake Michigan Coastal Program, and Donald Smales of Greeley and Hanson Engineers, LLC, provided valuable administrative and logistical support for the overall project and for several aspects of field work. Several National Park Service (NPS) personnel from the Indiana Dunes National Lakeshore made meaningful contributions to this study: Superintendent Constantine Dillon, Robert Daum, and Brenda Waters made administrative contributions, and Randy Grass and Charles Morris made technical contributions. Dr. Erin Argyilan and Kate Rumisek of Indiana University Northwest shared data and technical observations about the hydrology of the watershed near Ogden Dunes. David Bucaro and Joseph Schulenberg of the U.S. Army Corps of Engineers provided useful resources and feedback for further development of interim model products. Erica Barrow assisted with data collection.

The following current and former USGS personnel also helped with this project: Lee Watson (retired; well installation and data collection), David A. Cohen (retired; well and surface-water site installation, data collection, initial model construction and technical advice), Leslie $D$. Arihood (retired; initial model construction and technical advice), Cheryl Silcox (data collection), and Joseph Sullivan (USGS student employee). The authors would like to thank the following USGS personnel for their review of this report: Jack Eggleston (technical review; USGS Virginia Water Science Center), Martha Nielsen (technical review; USGS Maine Water Science Center), and Mike Eberle (editorial review; USGS Ohio Water Science Center). 



\section{Contents}

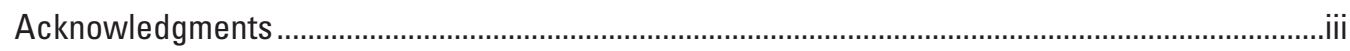

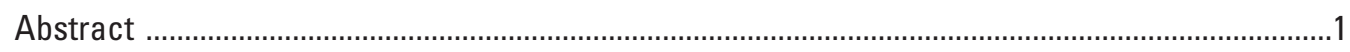

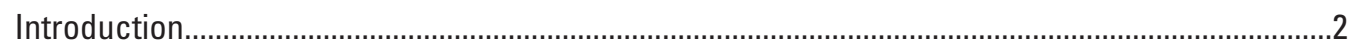

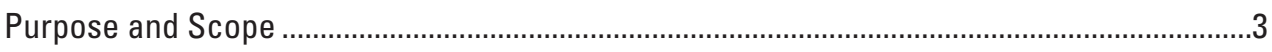

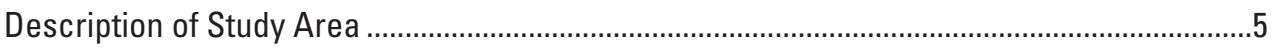

Groundwater and Surface-Water Resources ..........................................................................

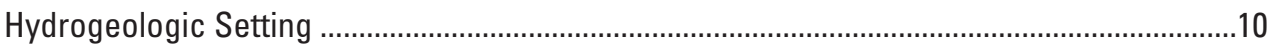

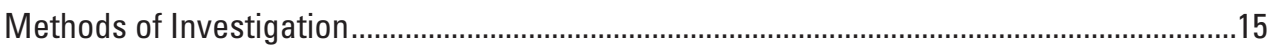

Groundwater Levels and Flow in the Surficial Aquifer ........................................................21

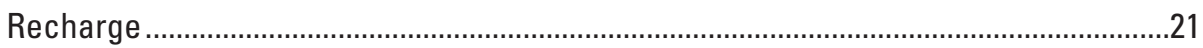

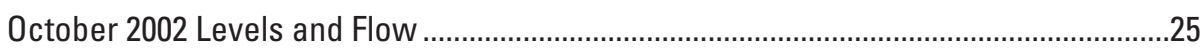

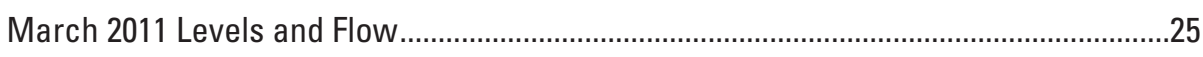

Groundwater/Surface-Water Interaction .................................................................29

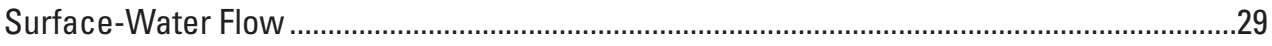

Hydrologic Modeling Parameters from Previous Studies ........................................................30

Simulation of Groundwater Flow and Availability ....................................................................

Simplifying Assumptions of the Conceptual Model ..............................................................

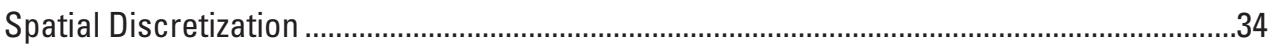

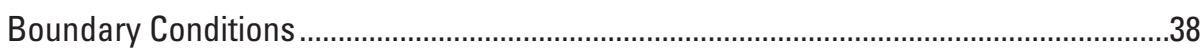

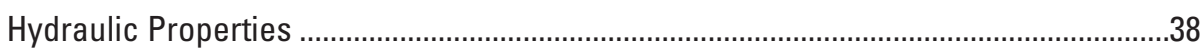

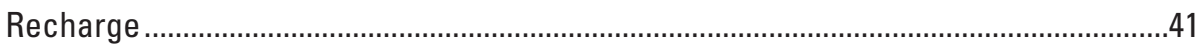

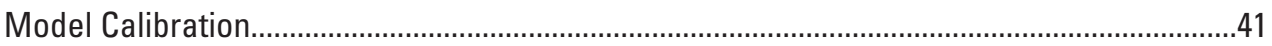

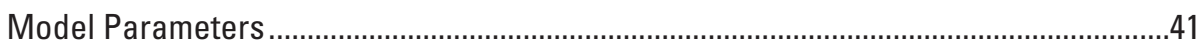

Observations and Observation Weights ....................................................................4

Changes in the Design of the Model During Calibration ..................................................45

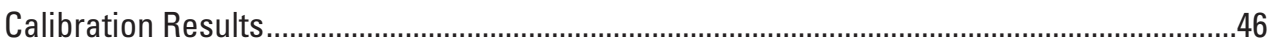

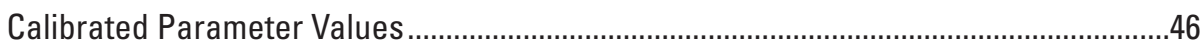

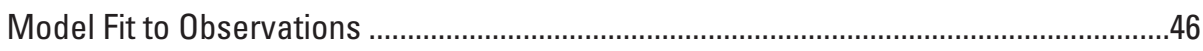

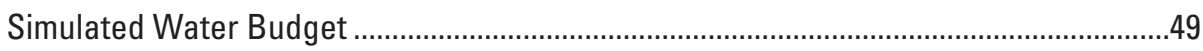

Simulated Water Levels and Groundwater Flow Paths................................................50

Simulated Inundated Areas ............................................................................................54

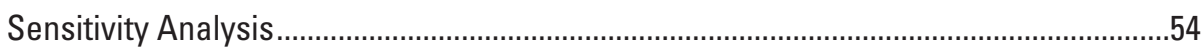

Model Simulations of Climatic Effects and Hydrologic Modifications to
Long Lake Watershed .......................................................................................56

Simulation of the Wet-Weather Hydrologic Condition in March 2011 ............................58

Adjustment of Parameter Values and Hydrologic Conditions ....................................58

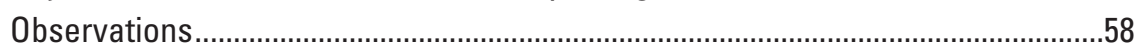

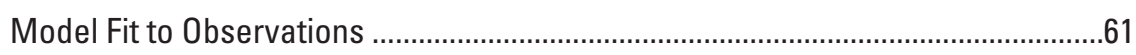

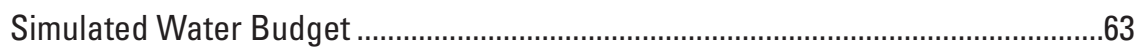

Simulated Water Levels and Groundwater Flow Paths...........................................64

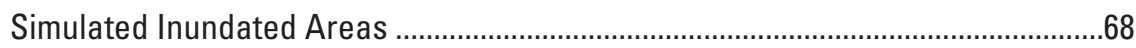


Simulated Removal of Beaver Dams from US-12 Ditch.................................................70

Simulated Discontinued Use of Water Treatment Plant Filtration Pond..........................72

Simulated Discontinuation of Discharge from US-12 Ditch............................................74

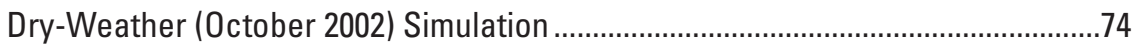

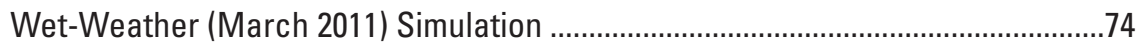

Simulation of Decreased Discharge from Basin by US-12 Ditch......................................77

Dry-Weather (October 2002) Simulation ...................................................................

Wet-Weather (March 2011) Simulation ...................................................................77

Simulation of Hydraulic Connection between East and West Long Lake ........................80

Simulated Deepening of County Line Road Ditch.............................................................82

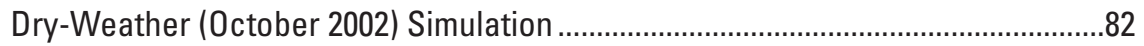

Wet-Weather (March 2011) Simulation ...............................................................82

Simulated Increase in Level of Lake Michigan.................................................................85

Dry-Weather (October 2002) Simulation ................................................................85

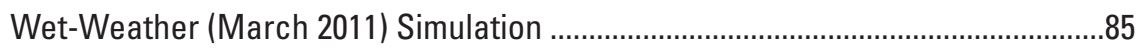

Simulated Decrease in Level of Lake Michigan .............................................................88

Dry-Weather (October 2002) Simulation ..................................................................8

Wet-Weather (March 2011) Simulation ....................................................................88

Discharge From US-12 Ditch as Simulated in All Scenarios ..................................................91

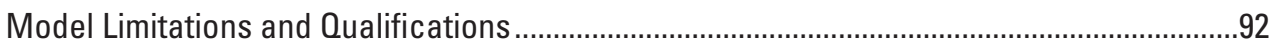

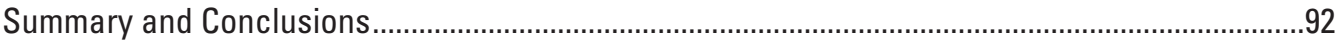

References

\section{Figures}

1-3. Maps showing:

1. Location of Gary, study area, and weather stations near the Indiana Dunes National Lakeshore, northwestern Indiana..............................................................

2. Approximate areal extent of Long Lake in 1902 ...................................................

3. Location of study area and surface-water data-collection sites in the Long Lake area, Indiana Dunes National Lakeshore, near Gary, Indiana..................6

4-5. Diagrams showing:

4. Interactions of precipitation with recharge and groundwater levels in a hypothetical unconfined sand aquifer

5. Generalized groundwater flow. $A$, Under natural conditions. $B$, Affected by tile drain flow. $C$, Affected by surface-water-level change in adjacent discharge ditch

6. Hydrogeologic section $A-A$ 'showing the surficial aquifer, confining unit, and underlying carbonate bedrock.

7-9. Maps showing:

7. Unconsolidated aquifer systems in the Lake Michigan region and the study area, northwestern Indiana.

8. Saturated thickness of the surficial aquifer on October 16,2002 , in the Long Lake area

9. Monitoring wells in the Long Lake area. 
10. Box-and-whisker plots of monthly precipitation statistics for the combined records from the weather stations at Ogden Dunes (1951 through 1989) and Indiana Dunes National Lakeshore, northwestern Indiana (1989 through 2009). A, Precipitation from November 2001 through October 2002. B, Precipitation from August 2010 through May 2011

11. Graph showing snow depth and temperature from records from the weather station at Indiana Dunes National Lakeshore, northwestern Indiana, August 2010 through May 2011

12-13. Maps showing:

12. Altitude of the water table in the surficial aquifer measured during dryweather conditions of October 16, 2002, in the vicinity of Long Lake, Indiana Dunes National Lakeshore, near Gary, Indiana

13. Altitude of the water table in the surficial aquifer measured during wetweather conditions of March 8, 2011, in the vicinity of Long Lake, Indiana Dunes National Lakeshore, near Gary, Indiana

14-15. Hydrographs of:

14. Continuous water-level altitude in six wells, October 2010-June 2011, near Long Lake at Indiana Dunes National Lakeshore.

15. Data for December 1-8, 2010, from streamgage USGS 04095090 on the

Portage-Burns Waterway at Portage, Indiana

16. Graph showing surface-water gradient (measured March 8, 2011) and surveyed streambed elevations of the ditch along County Line Road, near Indiana Dunes National Lakeshore, Indiana

17. Map showing model grid used in the simulation of groundwater flow in the vicinity of Long Lake, near Gary, Indiana

18. Diagram showing layering design for the model in the vicinity of Long Lake, near Gary, Indiana

19-22. Maps showing:

19. Areal distribution of the three sources of land-surface-elevation data used in the simulation of groundwater flow in the area near Long Lake, Indiana Dunes National Lakeshore, Indiana

20. Boundary conditions and types of stream cells used in the simulation of groundwater flow in the study area.

21. Location of zone of low horizontal and vertical hydraulic conductivity in layer 3 of the groundwater flow model.

22. Location of recharge zones in undeveloped, urban, wetland, and open-water zones of the groundwater flow model and point representing seepage of water from the filtration pond

23. Graphical analysis of model fit. $A$, Simulated and observed water levels.

$B$, Weighted simulated and weighted observed water levels. $C$, Normal probability plot of weighted residuals. $D$, Weighted residuals and simulated water levels.

24. Map showing difference between observed and simulated water levels for the calibrated dry-weather (October 2002) groundwater model of the area near Long Lake, Indiana Dunes National Lakeshore, Indiana.

25. Diagram showing flow interchange among the model and East Long Lake, West Long Lake, and the filtration pond for the calibrated dry-weather (October 2002) groundwater flow model 
26-27. Maps showing:

26. Simulated water-table contours from the dry-weather (October 2002) calibrated model

27. Flow lines representing simulated groundwater flow paths in the surficial aquifer under steady-state dry-weather conditions, October 2002

28. Diagrams showing vertical flow paths simulated with the dry-weather (October 2002) calibrated model. $A$, Flow paths along column 93 and through the US-12 ditch. B, Flow paths along column 290 and through East Long Lake.

29-30. Maps showing:

29. Simulated water-table position within the city of Gary and areas near Long Lake, Indiana Dunes National Lakeshore, Indiana, in October 2002 during dry-weather conditions.

30. Differences between observed and simulated water levels for the wetweather (March 2011) simulation of the area near Long Lake, Indiana Dunes National Lakeshore, Indiana

31. Diagram showing flow interchange among the model and East Long Lake, West Long Lake, and the filtration pond for the wet-weather (March 2011) simulation

32-33. Maps showing:

32. Simulated water-table contours from the wet-weather (March 2011) simulation

33. Flow lines representing simulated groundwater flow paths in the surficial aquifer under steady-state wet-weather conditions, March 2011

34. Diagram showing vertical flow paths simulated with the wet-weather (March 2011) simulation. $A$, Flow paths along column 93 and through the US-12 ditch. $B$, Flow paths along column 290 and through East Long Lake

35-48. Maps showing:

35. Simulated water-table position within the city of Gary and areas surrounding Long Lake, Indiana Dunes National Lakeshore, Indiana, in March 2011 during wet-weather conditions

36. Water-table position resulting from a model scenario simulating the removal of beaver dams from US-12 ditch under wet-weather (March 2011) conditions near Long Lake, Indiana Dunes National Lakeshore, Indiana ..

37. Water-table position resulting from a model scenario simulating the discontinued use of the water treatment plant filtration pond under dryweather (October 2002) conditions near Long Lake, Indiana Dunes National Lakeshore, Indiana ...

38. Water-table position resulting from a model scenario simulating the discontinuation of discharge from US-12 ditch to the Gary Sanitary District sewer system under dry-weather (October 2002) conditions near Long Lake, Indiana Dunes National Lakeshore, Indiana

39. Water-table position resulting from a model scenario simulating the discontinuation of discharge from US-12 ditch to the Gary Sanitary District sewer system under wet-weather (March 2011) near Long Lake, Indiana Dunes National Lakeshore, Indiana

40. Water-table position resulting from a model scenario simulating the discontinued use of the water treatment plant filtration pond, the increase of 4 feet in elevation of the weir plate at the terminus of US-12 ditch, and dry-weather (October 2002) conditions near Long Lake, Indiana Dunes National Lakeshore, Indiana. 
41. Water-table position resulting from a model scenario simulating the increase of 2 feet in elevation of the weir plate at the terminus of US-12 ditch under wet-weather (March 2011) conditions near Long Lake, Indiana Dunes National Lakeshore, Indiana.

42. Water-table position resulting from a model scenario simulating a hydraulic connection between East and West Long Lake and the discontinuation of discharge from US-12 ditch to the Gary Sanitary District sewer system under wet-weather (March 2011) conditions near Long Lake, Indiana Dunes National Lakeshore, Indiana

43. Mapped difference in the simulated water-table altitude between the dryweather (October 2002) simulation and a model scenario simulating the deepening of the ditch on the east side of County Line Road near Long Lake, Indiana Dunes National Lakeshore, Indiana.

44. Mapped difference in the simulated water-table altitude between the wetweather (March 2011) simulation and a model scenario simulating the deepening of the ditch on the east side of County Line Road near Long Lake, Indiana Dunes National Lakeshore, Indiana.

45. Water-table position resulting from a model scenario simulating the water level of Lake Michigan at extreme high level and dry-weather (October 2002) conditions near Long Lake, Indiana Dunes National Lakeshore, Indiana.

46. Water-table position resulting from a model scenario simulating the water level of Lake Michigan at extreme high level and wet-weather (March 2011) conditions near Long Lake, Indiana Dunes National Lakeshore, Indiana.

47. Inundated areas resulting from a model scenario simulating the water level of Lake Michigan at extreme low altitudes and dry-weather (October 2002) conditions near Long Lake, Indiana Dunes National Lakeshore, Indiana.

48. Inundated areas resulting from a model scenario simulating the water level of Lake Michigan at extreme low altitudes and wet-weather (March 2011) conditions near Long Lake, Indiana Dunes National Lakeshore, Indiana.

\section{Tables}

1. Lithostratigraphy of the study area in the context of northwestern Indiana hydrogeologic units. .12

2. Characteristics of groundwater monitoring wells in the study area ...16

3. Characteristics of surface-water data-collection sites in the study area .......................19

4. Water-level measurements made on October 16, 2002 ...............................................22

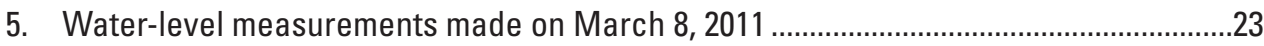

6. Discharge measurements on streams and ditches in the study area .............................29

7. Hydrologic parameters used or estimated from field measurements in previous studies in northwestern Indiana

8. Initial and final parameter values and parameter composite-scaled sensitivities for the dry-weather (October 2002) simulated condition

9. Measured (observed) and model-calculated (simulated) water levels and discharge measurement used as observations and model residuals for the October 2002 calibrated groundwater model

10. Computed statistics based on the water-level residuals for the dry-weather (October 2002) calibrated groundwater model 
12. Details of various simulated scenarios for both the dry-weather (October 2002) and wet-weather (March 2011) conditions

13. Parameters, their original values, and the adjusted values used to match the wetweather water-level data collected in March 2011.

14. Measured and model-calculated water levels and discharge measurements and modeled residuals for the March 2011 simulation

15. Computed statistics based on the unweighted water-level residuals for the wetweather (March 2011) hydrologic condition. 61

16. Water budget associated with the wet-weather (March 2011) simulation

17. Simulated values of discharge and percent difference in discharge from US-12 ditch for the simulations included in this report 
Conversion Factors and Abbreviations

\begin{tabular}{|c|c|c|}
\hline Multiply & By & To obtain \\
\hline \multicolumn{3}{|c|}{ Length } \\
\hline inch (in.) & 2.54 & centimeter $(\mathrm{cm})$ \\
\hline inch (in.) & 25.4 & millimeter (mm) \\
\hline foot (ft) & 0.3048 & meter $(\mathrm{m})$ \\
\hline mile (mi) & 1.609 & kilometer (km) \\
\hline \multicolumn{3}{|c|}{ Area } \\
\hline acre & 4,047 & square meter $\left(\mathrm{m}^{2}\right)$ \\
\hline acre & 0.4047 & hectare (ha) \\
\hline acre & 0.004047 & square kilometer $\left(\mathrm{km}^{2}\right)$ \\
\hline square mile $\left(\mathrm{mi}^{2}\right)$ & 259.0 & hectare (ha) \\
\hline square mile $\left(\mathrm{mi}^{2}\right)$ & 2.590 & square kilometer $\left(\mathrm{km}^{2}\right)$ \\
\hline \multicolumn{3}{|c|}{ Volume } \\
\hline gallon (gal) & 3.785 & liter (L) \\
\hline gallon (gal) & 0.003785 & cubic meter $\left(\mathrm{m}^{3}\right)$ \\
\hline million gallons (Mgal) & 3,785 & cubic meter $\left(\mathrm{m}^{3}\right)$ \\
\hline cubic foot $\left(\mathrm{ft}^{3}\right)$ & 0.02832 & cubic meter $\left(\mathrm{m}^{3}\right)$ \\
\hline \multicolumn{3}{|c|}{ Flow rate } \\
\hline foot per day (ft/d) & 0.3048 & meter per day $(\mathrm{m} / \mathrm{d})$ \\
\hline cubic foot per second $\left(\mathrm{ft}^{3} / \mathrm{s}\right)$ & 0.02832 & cubic meter per second $\left(\mathrm{m}^{3} / \mathrm{s}\right)$ \\
\hline gallon per day (gal/d) & 0.003785 & cubic meter per day $\left(\mathrm{m}^{3} / \mathrm{d}\right)$ \\
\hline million gallons per day (Mgal/d) & 0.04381 & cubic meter per second $\left(\mathrm{m}^{3} / \mathrm{s}\right)$ \\
\hline inch per year (in/yr) & 25.4 & millimeter per year (mm/yr) \\
\hline \multicolumn{3}{|c|}{ Hydraulic conductivity } \\
\hline foot per day (ft/d) & 0.3048 & meter per day $(\mathrm{m} / \mathrm{d})$ \\
\hline \multicolumn{3}{|c|}{ Hydraulic gradient } \\
\hline foot per mile (ft/mi) & 0.1894 & meter per kilometer $(\mathrm{m} / \mathrm{km})$ \\
\hline \multicolumn{3}{|c|}{ Transmissivity* } \\
\hline foot squared per day $\left(\mathrm{ft}^{2} / \mathrm{d}\right)$ & 0.09290 & meter squared per day $\left(\mathrm{m}^{2} / \mathrm{d}\right)$ \\
\hline
\end{tabular}

Temperature in degrees Celsius $\left({ }^{\circ} \mathrm{C}\right)$ may be converted to degrees Fahrenheit $\left({ }^{\circ} \mathrm{F}\right)$ as follows: ${ }^{\circ} \mathrm{F}=\left(1.8 x^{\circ} \mathrm{C}\right)+32$

Temperature in degrees Fahrenheit $\left({ }^{\circ} \mathrm{F}\right)$ may be converted to degrees Celsius $\left({ }^{\circ} \mathrm{C}\right)$ as follows: ${ }^{\circ} \mathrm{C}=\left({ }^{\circ} \mathrm{F}-32\right) / 1.8$

*Transmissivity: The standard unit for transmissivity is cubic foot per day per square foot times foot of aquifer thickness $\left[\left(\mathrm{ft}^{3} / \mathrm{d}\right) / \mathrm{ft}^{2}\right] \mathrm{ft}$. In this report, the mathematically reduced form, foot squared per day $\left(\mathrm{ft}^{2} / \mathrm{d}\right)$, is used for convenience.

Specific conductance is given in microsiemens per centimeter at 25 degrees Celsius $(\mu \mathrm{S} / \mathrm{cm}$ at $\left.25^{\circ} \mathrm{C}\right)$.

Concentrations of chemical constituents in water are given either in milligrams per liter (mg/L) or micrograms per liter $(\mu \mathrm{g} / \mathrm{L})$. 
Temperature in degrees Fahrenheit $\left({ }^{\circ} \mathrm{F}\right)$ may be converted to degrees Celsius $\left({ }^{\circ} \mathrm{C}\right)$ as follows: ${ }^{\circ} \mathrm{C}=\left({ }^{\circ} \mathrm{F}-32\right) / 1.8$

Vertical coordinate information is referenced to the North American Vertical Datum of 1988 (NAVD 88). Selected altitudes include a reference to the National Geodetic Vertical Datum of 1929 (NGVD 29), as specifically described in the report text.

Horizontal coordinate information is referenced to the North American Datum of 1983 (NAD 83).

Altitude, as used in this report, refers to distance above the vertical datum.

Time is referenced to Eastern Standard Time

\title{
Abbreviations and acronyms used in this report:
}

\author{
INDU Indiana Dunes National Lakeshore \\ IUN Indiana University Northwest \\ NAD 83 North American Datum of 1983 \\ NAVD 88 North American Vertical Datum of 1988 \\ NGVD 29 National Geodetic Vertical Datum of 1929 \\ NOAA National Oceanic and Atmospheric Administration \\ NPS National Park Service \\ PVC Polyvinylchloride \\ USGS U.S. Geological Survey \\ yr year \\ s second \\ d day \\ ks hydraulic conductivity of the surficial sand aquifer \\ ks_dirty hydraulic conductivity of the basal sand aquifer
}




\title{
Hydrologic Data and Groundwater Flow Simulations in the Vicinity of Long Lake, Indiana Dunes National Lakeshore, Near Gary, Indiana
}

\author{
By David C. Lampe and E. Randall Bayless
}

\section{Abstract}

The U.S. Geological Survey (USGS) collected data and simulated groundwater flow to increase understanding of the hydrology and the effects of drainage alterations to the water table in the vicinity of Long Lake, near Gary, Indiana. East Long Lake and West Long Lake (collectively known as Long Lake) make up one of the largest interdunal lakes within the Indiana Dunes National Lakeshore. The National Park Service is tasked with preservation and restoration of wetlands in the Indiana Dunes National Lakeshore along the southern shoreline of Lake Michigan. Urban development and engineering have modified drainage and caused changes in the distribution of open water, streams and ditches, and groundwater abundance and flow paths. A better understanding of the effects these modifications have on the hydrologic system in the area will help the National Park Service, the Gary Sanitary District (GSD), and local stakeholders manage and protect the resources within the study area.

This study used hydrologic data and steady-state groundwater simulations to estimate directions of groundwater flow and the effects of various engineering controls and climatic conditions on the hydrology near Long Lake. Periods of relatively high and low groundwater levels were examined and simulated by using MODFLOW and companion software. Simulated hydrologic modifications examined the effects of (1) removing the beaver dams in US-12 ditch, (2) discontinuing seepage of water from the filtration pond east of East Long Lake, (3) discontinuing discharge from US-12 ditch to the GSD sewer system, (4) decreasing discharge from US-12 ditch to the GSD sewer system, (5) connecting East Long Lake and West Long Lake, (6) deepening County Line Road ditch, and (7) raising and lowering the water level of Lake Michigan.

Results from collected hydrologic data indicate that East Long Lake functioned as an area of groundwater recharge during October 2002 and a "flow-through" lake during March 2011, with the groundwater divide south of US-12. Wetlands to the south of West Long Lake act as points of recharge to the surficial aquifer in both dry- and wet-weather conditions.
Among the noteworthy results from a dry-weather groundwater flow model simulation are (1) US-12 ditch does not receive water from East Long Lake or West Long Lake, (2) the filtration pond at the east end of East Long Lake, when active, contributed approximately 10 percent of the total water entering East Long Lake, and (3) County Line Road ditch has little effect on simulated water level.

Among the noteworthy results from a wet-weather groundwater flow simulation are (1) US-12 ditch does not receive water from East Long Lake or West Long Lake, (2) when the seepage from the filtration pond to the surficial aquifer is not active, sources of inflow to East Long Lake are restricted to only precipitation (46 percent of total) and inflow from the surficial aquifer (54 percent of total), and (3) County Line Road ditch bisects the groundwater divide and creates two water-table mounds south of US- 12 .

The results from a series of model scenarios simulating certain engineering controls and changes in Lake Michigan levels include the following: (1) The simulated removal of beaver dams in US-12 ditch during a wet-weather simulation increased discharge from the ditch to the Gary Sanitary system by 13 percent. (2) Discontinuation of seepage from the filtration pond east of East Long Lake decreased discharge from US- 12 ditch to the Gary Sanitary system by 2.3 percent. (3) Simulated discontinuation of discharge from the US-12 ditch to the GSD sewer system increased the area where the water table was estimated to be above the land surface beyond the inundated area in the initial wet-weather simulation. (4) Simulated modifications to the control structure at the discharge point of US-12 ditch to the GSD sewer system can decrease discharge by as much as 61 percent while increasing the simulated inundated area during dry weather and decrease discharge as much as 6 percent while increasing the simulated inundated area during wet weather. (5) Deepening of County Line Road ditch can decrease the discharge from US-12 ditch by 26 percent during dry weather and 24 percent during wet weather, as well as decrease the extent of flooded areas south and east of the filtration pond near Ogden Dunes. (7) The increase of the Lake Michigan water level to match the 
historical maximum can increase the discharge from US-12 ditch by 14 percent during dry weather and by 9.6 percent during wet weather. (8) The decrease of the Lake Michigan water level to match the historical minimum can decrease the discharge from US-12 ditch by 7.4 percent during dry weather and by 3.1 percent during wet weather.

The results of this study can be used by water-resource managers to understand how surrounding ditches affect water levels in East and West Long Lake and in the surrounding wetlands and residential areas. The groundwater model developed in this study can be applied in the future to answer questions about how alterations to the drainage system in the area will affect water levels in East and West Long Lake and surrounding areas. The modeling methods developed in this study provide a template for other studies of groundwater flow and groundwater/surface-water interactions within the shallow surficial aquifer in northern Indiana, and in similar hydrologic settings that include surficial sand aquifers in coastal settings.

\section{Introduction}

The Indiana Dunes National Lakeshore (INDU) was formally established in 1973 as part of a continuing effort to preserve the dunes and wetlands along the southern shore of Lake Michigan in northwestern Indiana (fig. 1). The National Park Service (NPS) is charged with preserving and managing the
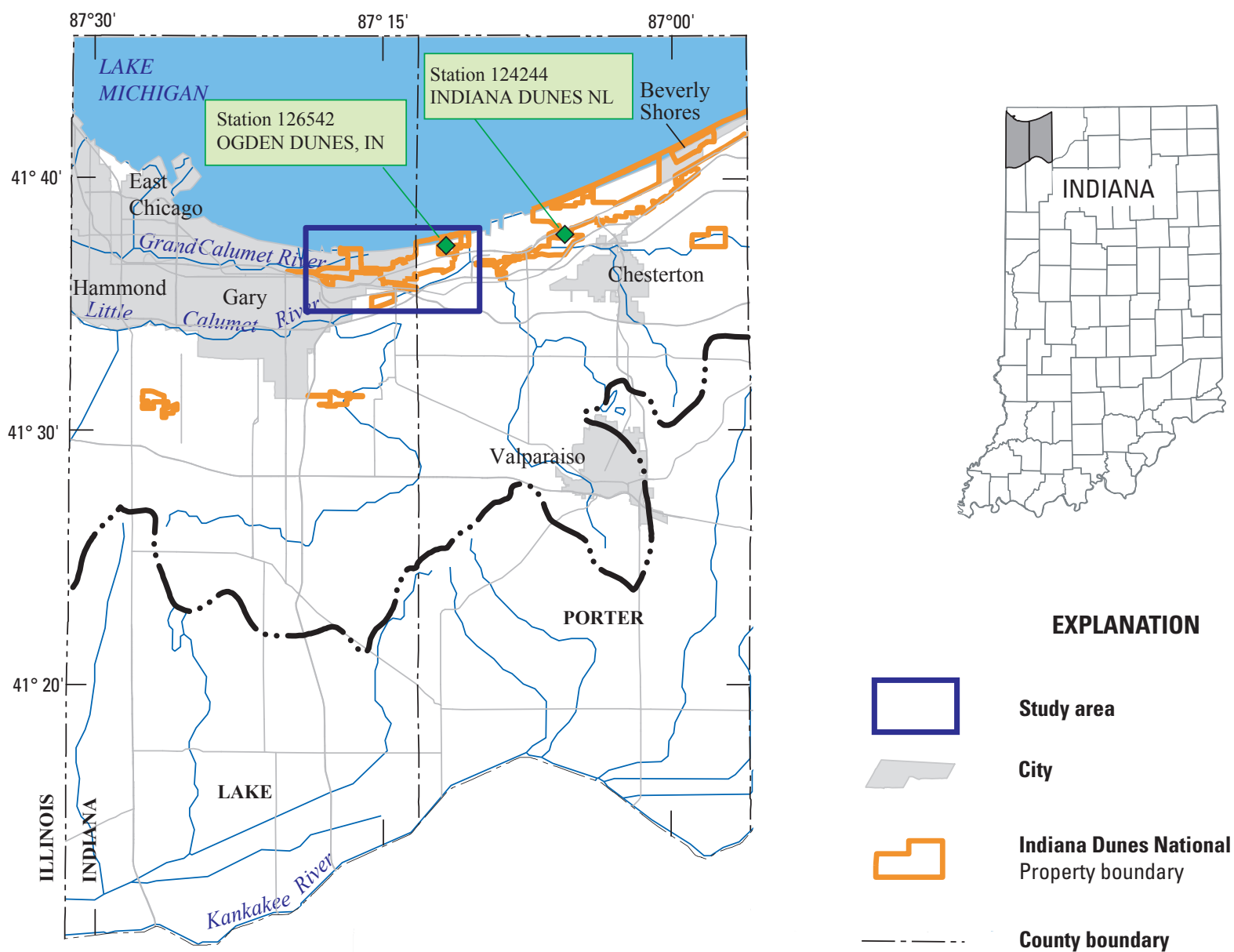

EXPLANATION

Base from U.S. Geological Survey digital data 1983, 1:100,000

Universal Transverse Mercator projection, Zone 16

Standard parallel $0^{\circ}$ (Equator), Central meridian $87^{\circ} \mathrm{W}$

North American Datum 1983

Study area

City

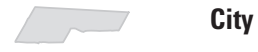

Indiana Dunes National Lakeshore-

Property boundary

- - - County boundary

_... Lake Michigan basin boundary

Precipitation station used for this study

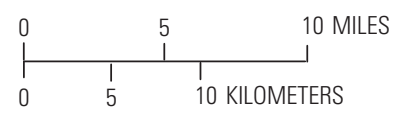

Figure 1. Location of Gary, study area, and weather stations near the Indiana Dunes National Lakeshore, northwestern Indiana. 
aesthetic, scientific, and recreational resources of the INDU. Industrial and urban development during the last century has substantially modified the study area. Changes to the natural drainage system and other cultural disturbances have affected the hydrology of the lake-wetland complex in the vicinity of East Long Lake and West Long Lake (referred to in combination as "Long Lake") (fig. 2). The Gary Sanitary District (GSD), NPS, and other resource managers in the area require an improved understanding of the hydrology in the vicinity of Long Lake in order to understand the effects of drainage alterations to the water levels of East and West Long Lake and to the water table in the surrounding residential areas.

The U.S. Geological Survey (USGS) provides reliable scientific information to describe the interaction of hydrologic systems and assists in understanding their effects on natural lands and property. In most instances, these efforts involve documenting and analyzing the effects of widely recognized phenomena such as surface-water and groundwater flow and quality. On occasion, they involve relatively small-scope studies of previously unrecognized phenomena, such as the use of groundwater flow simulations to understand interactions of changes in groundwater drainage with wetland water levels and the potential for groundwater flooding. The USGS works within its strategic science direction and with its partner organizations, such as the GSD, the U.S. Army Corps of Engineers, and the NPS, to document these emerging hazards and to ensure that scientific methods are applied effectively for better understanding these phenomena at INDU and in similar hydrologic settings that include surficial sand aquifers in coastal settings.

The USGS and the NPS initiated an investigation in October 2000 to evaluate the hydrology in the vicinity of Long Lake that included measurement of surface-water and groundwater levels and development of a steady-state groundwater flow model. The USGS, the U.S. Army Corps of Engineers, the GSD, and the Indiana Lake Michigan Coastal Grants Program joined the effort during 2010, emphasizing an analysis of water-level differences between dry and wet-weather conditions and the importance of cultural modifications to the hydrologic system. An understanding of the hydrologic system was needed to (1) manage and restore Long Lake, (2) understand the effects on the hydrologic system and the surrounding residential and natural areas that result from drainage modifications and other cultural disturbances that have been made, are planned, or are hypothetical, and (3) estimate the effects of climate and Lake Michigan water level on Long Lake and the INDU. This investigation by the USGS and its partners will aid in comprehending how natural and human-affected hydrologic processes affect shallow groundwater levels in an unconfined surficial aquifer surrounding and beneath East and West Long Lake in the INDU on the boundary between Lake and Porter Counties, Indiana (Ind.).

\section{Purpose and Scope}

This report presents data, describes a groundwater flow model that was developed, and discusses the results of the investigation. The groundwater flow model will also be available, if needed, as a tool to help evaluate future management actions.

Water levels were measured to understand flow directions in the surficial aquifer and establish a consistent reference to compare with and quality assure the groundwater flow simulations. Continuous water-level and weather data also are presented and interpreted to determine steady-state "dry-weather" and "wet-weather" water-level periods in the surficial aquifer. These datasets are used to calibrate a steady-state groundwater flow representing dry-weather, average conditions.

The purpose of the calibrated groundwater model is to numerically represent the shallow hydrologic system of the area surrounding East and West Long Lake so that various simulations can be made that represent different drainage modifications and climatic conditions. Nine different scenarios were completed:

- Simulating a wet-weather hydrologic condition.

- Removing the simulation of beaver dams in US-12 ditch.

- Removing the influx of water for the filtration pond east of East Long Lake.

- Ending the discharge of water from the US-12 ditch to the GSD sewer system.

- Decreasing the discharge from the US-12 ditch to the GSD sewer system.

- Connecting East Long Lake to West Long Lake with a simulated culvert to create a continuous basin.

- Deepening the County Line Road ditch.

- Simulating an increase in the water level of Lake Michigan.

- Simulating a decrease in the water level of Lake Michigan.

The study determines the effects of the drainage modifications and climatic conditions on the surrounding residential and natural areas by comparing simulation results for each scenario to baseline conditions or the results of another scenario. Water-table elevations for each simulation are compared with the altitudes of hypothetical subgrade structures (basements, roadbeds, or railbeds) in the model area. 


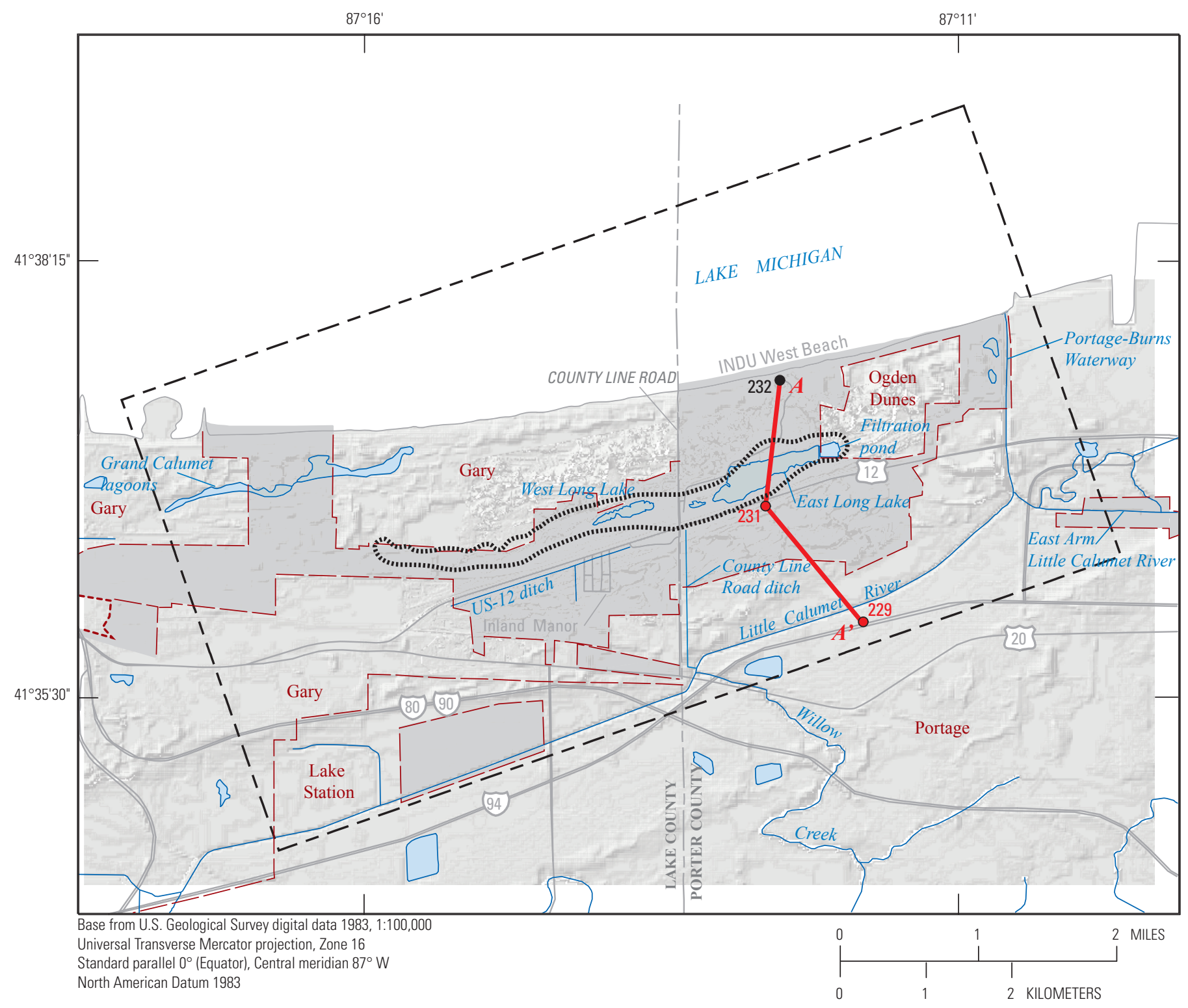

EXPLANATION

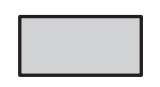

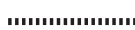

$A=A$, Hydrogeologic section traceSection shown in figure 6

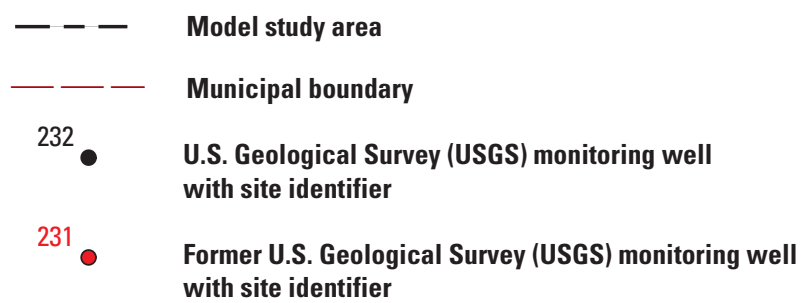

Figure 2. Approximate areal extent of Long Lake in 1902 (areal extent of Long Lake modified from U.S. Army Corps of Engineers, 1902). 


\section{Description of Study Area}

Long Lake is an interdunal lake (between dune ridges) within the Indiana Dunes National Lakeshore (INDU) in northern Lake and Porter Counties in northwestern Indiana (fig. 2) and is one of the largest interdunal lakes within the park. Long Lake is divided into an eastern body and a smaller western body by the north-south trending County Line Road. The lake is bordered by interdunal wetlands that are seasonally saturated. The wetlands that surround East and West Long Lake are bordered by the municipalities of Gary (to the north, west, and southwest), Portage (to the southeast), and Ogden Dunes (to the east).

The climate along the southern shore of Lake Michigan, including the Long Lake study area, is characterized by hot, humid summers and cold winters. The mean precipitation is approximately $36 \mathrm{in} / \mathrm{yr}$, including approximately 30 to $40 \mathrm{in} / \mathrm{yr}$ of snowfall (Midwestern Regional Climate Center, 2010). Monthly mean precipitation is lowest in February (approximately $1.5 \mathrm{in}$.) and highest in June and July (3.8 in.). The mean January temperature is $24^{\circ} \mathrm{F}$, and the mean July temperature is $73^{\circ} \mathrm{F}$ (National Oceanic and Atmospheric Administration, 1982; Greeman, 1995).

Historical maps of northwestern Indiana from 1833, 1889 (Moore, 1959, p. 57 and 179), and 1902 (U.S. Army Corps of Engineers, 1902) show one contiguous body of water, labeled as Long Lake, that straddled the county line between Lake and Porter Counties in the same general location as the two separate water bodies, East Long Lake and West Long Lake, do today (fig. 2). The open-water lake area shown in these older maps is substantially larger than the open-water lake areas today (Brennan, 1923, p. 143-144; Richard Whitman, U.S. Geological Survey, oral commun., 2002). Since that time, industrial and urban development has surrounded the INDU, and natural drainage systems have been altered along transportation corridors and near residential areas, including the shrinking and splitting of Long Lake into two separate areas of open water on the east and west sides of County Line Road (fig. 2). The open-water area of East Long Lake is substantially larger and generally deeper than the open-water area of West Long Lake. Bathymetric data indicate that water depths range from 0.1 to $4.7 \mathrm{ft}$ with a mean of $2.2 \mathrm{ft}$ for East Long Lake and from 0.2 to $4.0 \mathrm{ft}$ with a mean of $1.4 \mathrm{ft}$ for West Long Lake (Lee R. Watson, U.S. Geological Survey (retired), written commun., 2003).

Surface water in most of the study area drains to Lake Michigan (fig. 3). Surface water drains directly to Lake Michigan along a narrow strip of shoreline bordering the lake. In most of the southern two-thirds of the study area, surface water flows directly into the Little Calumet River or into a tributary of the river and discharges to Lake Michigan. In the northwestern quarter of the study area, most of the drainage is to the Grand Calumet lagoons; a buried culvert conveys water from the lagoons to the Grand Calumet River, eventually discharging to Lake Michigan through the Indiana Harbor Canal approximately $11 \mathrm{mi}$ west of the study area. The central third of the Long Lake study area forms a topographically closed basin with drainage to East and West Long Lake and the US-12 ditch. Water is drained from the central part of the study area to the south into the Little Calumet River by County Line Road ditch on the east side of County Line Road (fig. 3).

Specific alterations and development activities in the area surrounding Long Lake (before the establishment of INDU) included the following:

1. Mining of sand along the north shore of Long Lake on the east side of the present County Line Road in the 1890s for use as fill and construction in the Chicago area. Brennan (1923, p. 133-134) and Moore (1959, p. 100-101) reported the entire removal of some of the highest dunes in the area.

2. Development of a centrally located transportation corridor to include two to four railroad tracks and highway US-12. Highway US-12 through the study area was completed in the early 1920s (Moore, 1959, p. 605).

3. Development of the community of Ogden Dunes immediately east of Long Lake. Ogden Dunes, which was incorporated in 1925, had fewer than 30 residents in 1930 (Moore, p. 606-607) but more than 1,100 residents by 2010 (U.S. Census Bureau, 2010).

4. Modifications to the Little Calumet River, completed in 1926, generally reversing flow in the river, causing it to discharge through the Portage-Burns Waterway and into Lake Michigan.

5. Expansion of the Gary residential area eastward to the Lake-Porter County line.

6. Development of the Inland Manor residential area on the south side of US-12 sometime before 1940 (Clement and others, 1940).

7. Building of County Line Road sometime before 1940 (Clement and others, 1940), effectively dividing the open-water area of Long Lake into eastern and western portions. A culvert may have been installed under County Line Road between East and West Long Lake (Richard Whitman, U.S. Geological Survey, oral commun., 2002); however, during this study, no visual evidence of a culvert was found. A ground-penetrating radar survey along County Line Road north of US-12 during 2003 indicated a subsurface feature that could be interpreted as a metal culvert approximately $650 \mathrm{ft}$ north of US- 12 and $1.5 \mathrm{ft}$ below the road surface (Todd Thompson, Indiana Geological Survey, oral commun., 2003).

8. Construction of a 1.4-mi-long ditch on the south side of US-12 with a 0.25 -mi-long north-south oriented arm on the west side of Inland Manor; the ditch is informally referred to in this report as the "US-12 ditch." The ditch was probably constructed to aid development of the 


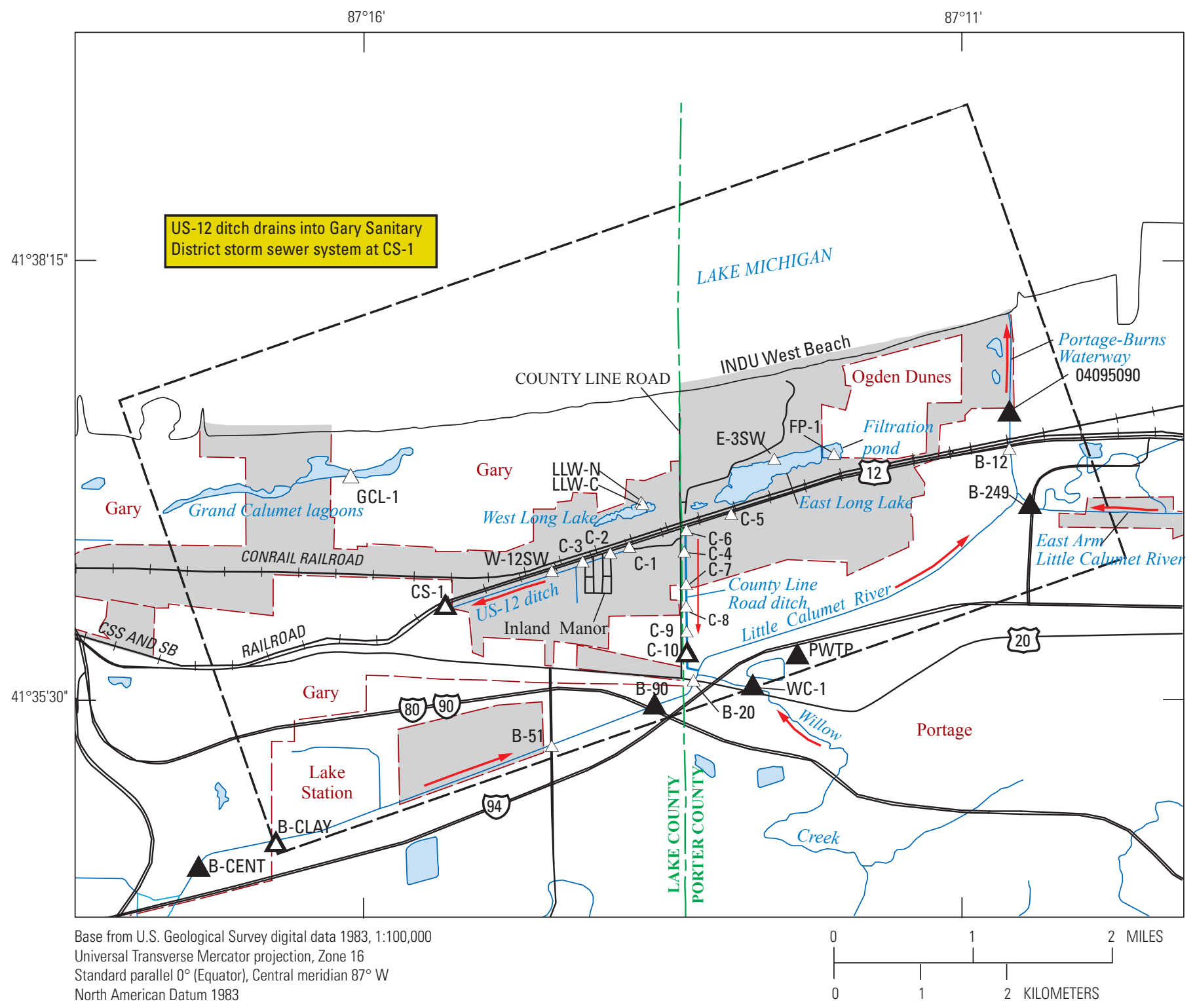

\section{EXPLANATION}

Indiana Dunes National Lakeshore (INDU)

Model boundary

- - Municipal boundary

$\longrightarrow$ Arrow indicating direction of surface-water flow

B-20 $\triangle$

Surface-water stage-measurement with site identifier

CS-1

Surface-water discharge-measurement site with site identifier

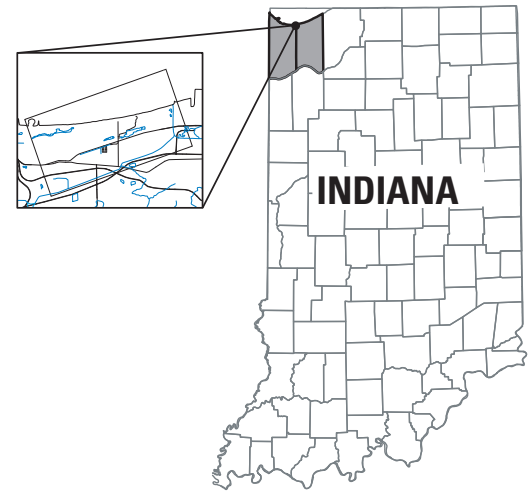

Figure 3. Location of study area and surface-water data-collection sites in the Long Lake area, Indiana Dunes National Lakeshore, near Gary, Indiana. 
Inland Manor area by locally lowering the water table to facilitate home construction. The ditch currently terminates at a concrete drop-structure and weir (site CS-1; fig. 3). Water entering the ditch is conveyed via a buried culvert into the sanitary sewers of the Gary Sanitary District and removed from the Long Lake basin (Don Smales, former superintendent, Gary Sanitary District wastewater treatment plant, oral commun., 2001).

9. Construction of a holding pond of about 8 acres in the mid-1960s at the east end of East Long Lake to retain filter-backwash particulates removed during water treatment at a nearby plant (Ken Buczek, Indiana American Water Company, oral commun., 2002). Use of the holding pond ceased in December of 2009. The dikes that retain the pond and separate it from East Long Lake were constructed of native materials during the mid-1960s and are still in place (Paul Anderson, Indiana American Water Company, oral commun., 2004).

10. Construction of the ditch on the east side of County Line Road south of US-12, draining water south to the Little Calumet River, informally referred to in this report as the "County Line Road ditch."

Possible future modifications to the local hydrologic system may include eliminating or decreasing discharges from the US-12 ditch into the Gary sanitary sewers. A potential side effect of eliminating drainage from US-12 ditch to the sewers could be a rise in water levels in the surficial aquifer and Long Lake; a rise in the water table could result in groundwater flooding of subgrade structures. Eliminating beaver dams and clogged culverts in study-area ditches is another hypothetical management action that could also affect the hydrologic system.

Owing to a relatively shallow water-table in the area surrounding Long Lake, several areas are susceptible to groundwater flooding in response to rapid infiltration of precipitation into the surficial aquifer:

- Inland Manor, a residential community of approximately 50 acres that is immediately south of US-12 in the central part of the study area. It is estimated that only 10 homes remain in Inland Manor. Other residences in the area were previously acquired by the NPS.

- Residential areas in eastern Gary. Low-lying areas immediately west of US-12 ditch are subject to flooding because of the relatively shallow water-table and absence of ditches to convey surface-water discharge away from the area.
- Southwestern parts of Ogden Dunes. Low-lying areas of Ogden Dunes near the filtration pond east of East Long Lake experienced flooding in 2006-8.

Two conceptual diagrams illustrate typical interactions of precipitation and recharge with changes in groundwater levels in a hypothetical unconfined sand aquifer (figs. 4 and 5). Precipitation that falls on the land surface, minus losses from evaporation and plant transpiration (evapotranspiration), can pond at the land surface, run off into surface water, or infiltrate through the unsaturated zone to groundwater as recharge (fig. 4). Other processes that can contribute to recharge is the discharge of water from septic systems, leaky sewers, or irrigation systems. A building and its basement can be vulnerable to infiltration and groundwater flooding of the basement if the water table rises above the basement floor (estimated to occur approximately $7 \mathrm{ft}$ below the land surface) or sump underdrain and the sump pump is unable to withdraw sufficient water to lower the groundwater level below basement floors and maintain dry conditions (fig. 4).

Outflow from the surficial aquifer shown in figure 5 occurs in the form of groundwater seepage directly to ditches, wetlands, and Lake Michigan (fig. 5, diagram $A$ ) and indirectly to those surface-water bodies through ditches or subsurface drains (fig. 5, diagram $B$ ) or to the atmosphere by seasonal processes such as transpiration (fig. 4). Withdrawals from the aquifer occur when water is pumped from shallow wells in the surficial aquifer for domestic supply and lawn irrigation or by sump pumps used for dewatering basements and areas near building foundations (fig. 4, diagram $B$ ). Sump withdrawals of groundwater are typically discharged within the same property, so these withdrawals may be essentially recycled. Withdrawals from sumps would lower groundwater levels near the building and slightly raise groundwater levels where the water is discharged but would produce little overall change in groundwater levels or flow (fig. 4).

The rate and volume of groundwater flow through a porous medium, such as in an unconfined sand aquifer, are directly proportional to the slope of the water-level surface (gradient) and the conductive characteristics of the aquifer to water (hydraulic conductivity). A water-table altitude can rise because of increased amounts of recharge or decreased amounts of groundwater outflow. Recharge can increase when more precipitation falls or when water brought into an area increases infiltration to the water table. Discharge of groundwater from the hypothetical aquifer can decrease if flow to a ditch is reduced by clogging from debris or beaver dams or if water levels rise in a groundwater discharge area, such as a lake, ditch, or wetland (fig. 5, diagram $C$ ). 
A. Conceptual diagram of parts of the water budget under the dune-beach complex, dry-weather (0ctober 2002) conditions

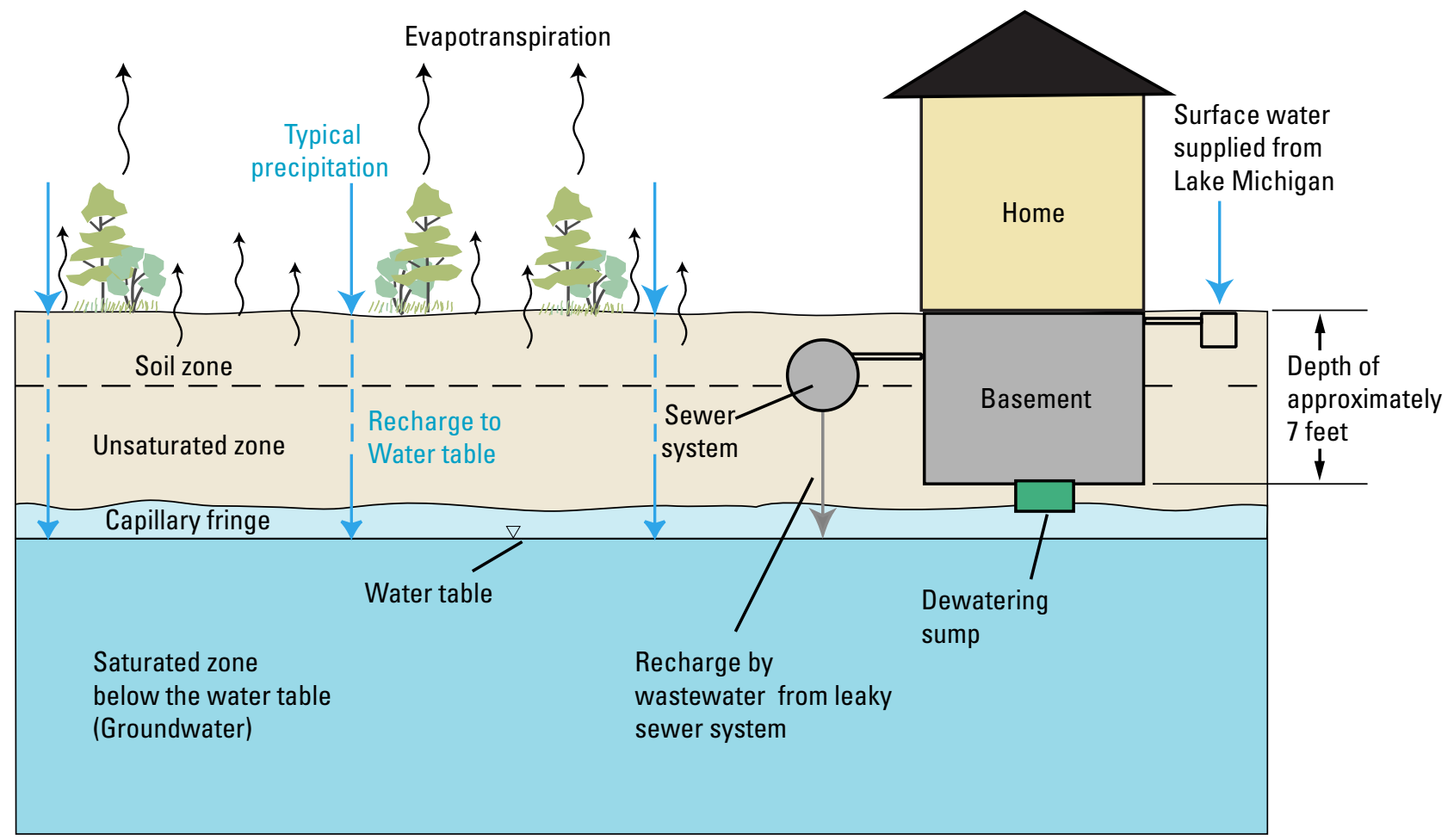

B. Conceptual diagram of parts of the water budget under the dune-beach complex, wet-weather (March 2011) conditions

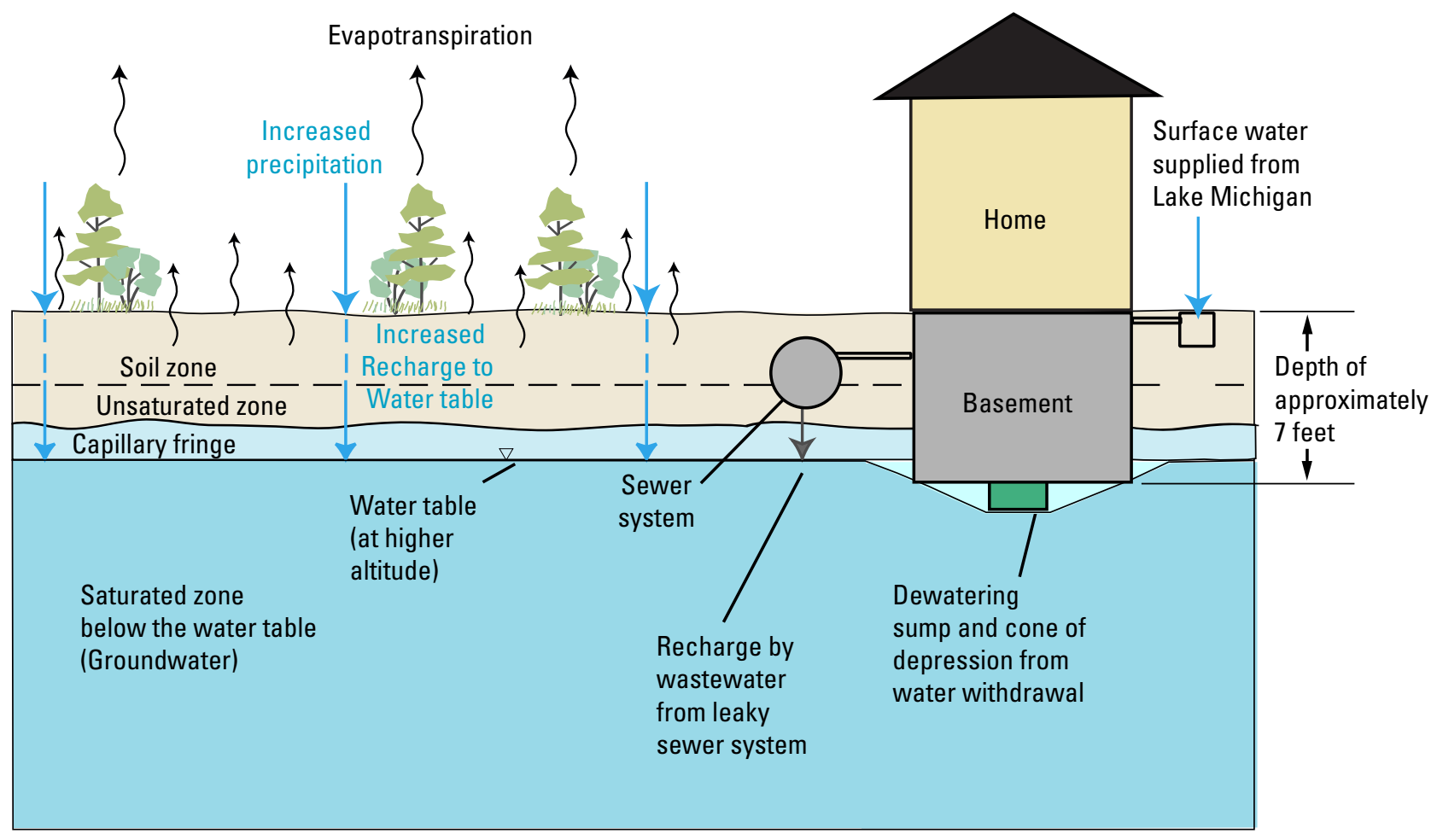

Figure 4. Interactions of precipitation with recharge and groundwater levels in a hypothetical unconfined sand aquifer. (Note that precipitation in $A$ is less than in $B$.) 
A.

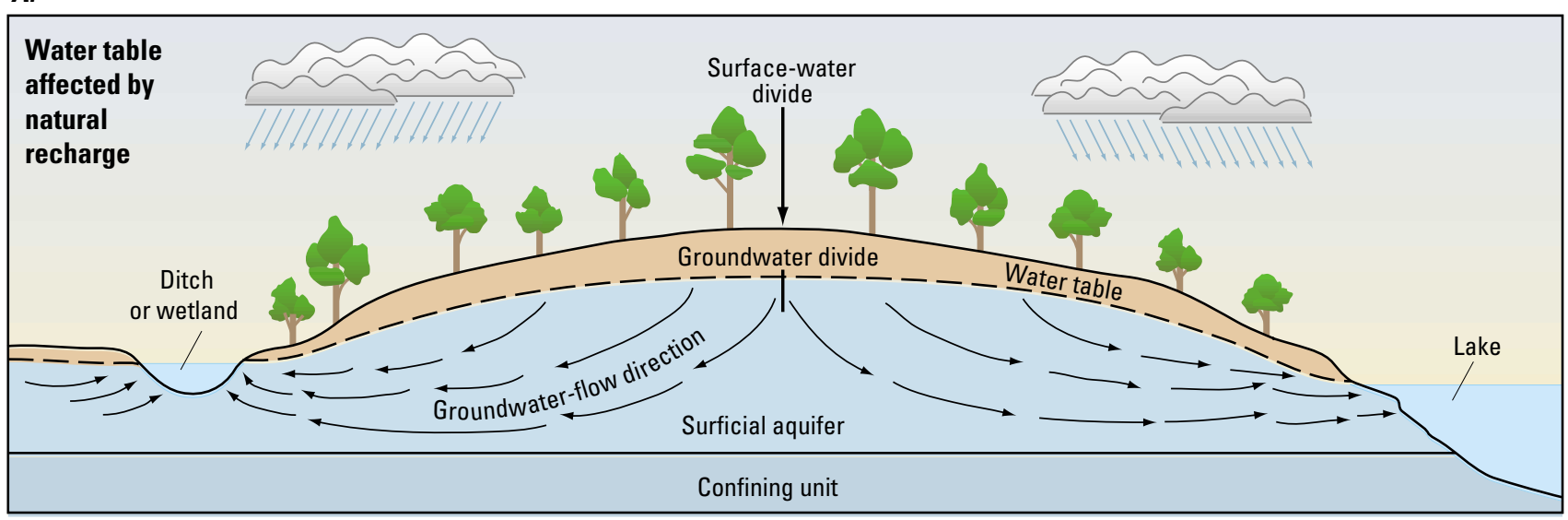

B.

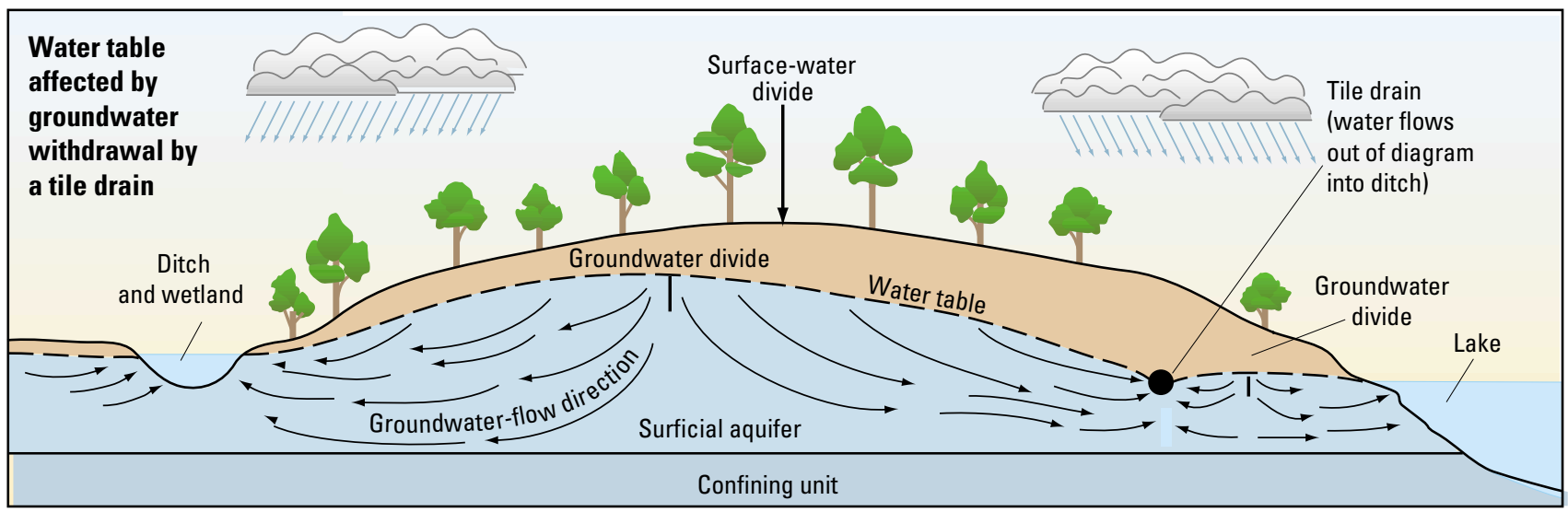

C.

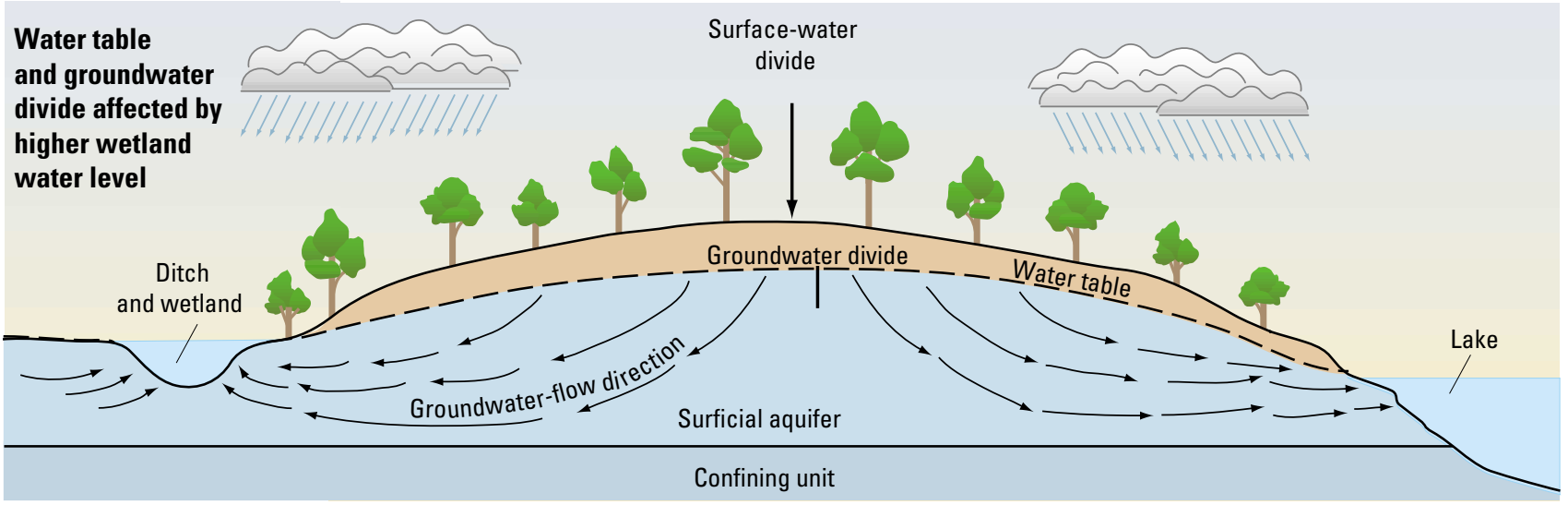

Diagrams reproduced and modified from

Grannemann and others (2000, fig. 5, p. 5).

Figure 5. Generalized groundwater flow. $A$, Under natural conditions. $B$, Affected by tile drain flow. $C$, Affected by surface-waterlevel change in adjacent discharge ditch. (Note that surface-water and groundwater divides coincide in $A$ but not in $B$ or $C$.) 


\section{Groundwater and Surface-Water Resources}

Many factors affect water resources in the study area. Groundwater flow is influenced by the hydraulic properties of the geologic units that constitute the local aquifers, in addition to the timing and quantity of recharge. Topography, streams, ditches, ponds and wetlands, and climate affect surface-water flow. Groundwater- and surface-water flow systems are in close hydraulic connection, especially in the highly permeable surficial geologic materials.

\section{Hydrogeologic Setting}

The study area lies within the Calumet Lacustrine Plain physiographic province (Malott, 1922; Gray, 2000). The province is characterized by dune-beach complexes - areas that contain many individual dunes with total relief of 50-100 ft between the tops and bottoms of adjacent dune lowlands but with water tables that do not follow the dune topography because of the highly permeable dune materials. These dunebeach complexes were deposited over the area formerly occupied by glacial Lake Chicago and formed during the Holocene Epoch and represent relic shorelines from when post-Pleistocene Lake Chicago receded (Hartke and others, 1975). Long Lake and associated interdunal wetlands occupy an elongated lowland between these dune-beach complexes (fig. 6).

Groundwater resources in the study area are made up of the Calumet Aquifer system ${ }^{1}$ and, to a lesser extent, the Lacustrine Plain Aquifer system ${ }^{1}$ (fig. 7) and one underlying bedrock aquifer system (the Silurian-Devonian Carbonate Aquifer system ${ }^{1}$ ).

The hydrogeologic framework of the study area consists of two unconsolidated aquifers - the surficial aquifer and, in the southeasternmost part of the study area, the basal sand aquifer-typically separated by variable thicknesses of glacial till and lacustrine clay and silt (table 1; Shedlock and others, 1994, fig. 10). The aquifer materials beneath the study area are made up of approximately 30-170 ft of unconsolidated glacial, lacustrine, eolian, and paludal sediments that were deposited on a bedrock surface modified by pre-Pleistocene erosion. The unconsolidated material is thinnest in the wetland areas in the southwest part of the study area near the Little Calumet River and in Gary just east of the Grand Calumet lagoons; it is thickest in areas of Ogden Dunes in the eastern part of the study area. The underlying bedrock consists mostly of Devonian limestones and dolomites of the Muscatatuck Group.

The surficial aquifer consists primarily of lacustrine and wind-blown sands and is commonly called the Calumet aquifer (Hartke and others, 1975; Shedlock and others, 1994). The saturated thickness of the surficial aquifer in the study area ranges from approximately 20 to greater than $50 \mathrm{ft}$ (fig. 8). In much of the central part of the study area, lowland areas generally have relatively thin (from less than 1 to about $8 \mathrm{ft}$ ) wetland deposits of muck, peat, calcareous clay, and other organic sediments at the surface. These organic deposits are associated with back-barrier deposits and other former wetland areas associated with higher levels of the post-Pleistocene Lake Chicago (Shedlock and others, 1994; Thompson, 1987). Generally, the surficial aquifer is unconfined throughout most of the study area. In some areas, however, buried organic sediments may function as local confining layers for underlying parts of the surficial aquifer and may also create perched water tables. This condition may prevail in the south-central, southeastern, and eastern parts of the modeled area, as inferred from a $\log$ for a well approximately one-half mile south of monitoring well W-1A (fig. 9) and also from the modeling results.

The basal sand aquifer in the INDU is described as interbedded clay, sand, gravel and till by Shedlock and others (1994, p. 16), who state that its extent is less well known than that of other aquifers in the area and that its presence in the western part of INDU is largely unknown. Buried organic sediments in the south-central, southeastern, and eastern parts of the modeled area may be characteristic of either the transition sediments from the surficial aquifer to the basal sand aquifer or the basal sand aquifer itself.

Little information is available regarding the thickness, areal distribution, and composition of the surficial organic sediments throughout the study area. Probing with a 10-ft-long steel rod in and around East Long Lake and West Long Lake indicated organic-sediment thicknesses that ranged from 0 to greater than $10 \mathrm{ft}$ and were mostly between 2 and $7 \mathrm{ft}$. The pattern in organic thickness is consistent with their formation in wetland environments on the landward side of former beach ridges identified in this area (Todd Thompson, Indiana Geological Survey, written commun., 2003; Thompson, 1992).

${ }^{1}$ Aquifer-system names are local usage; see Beaty (1994). 

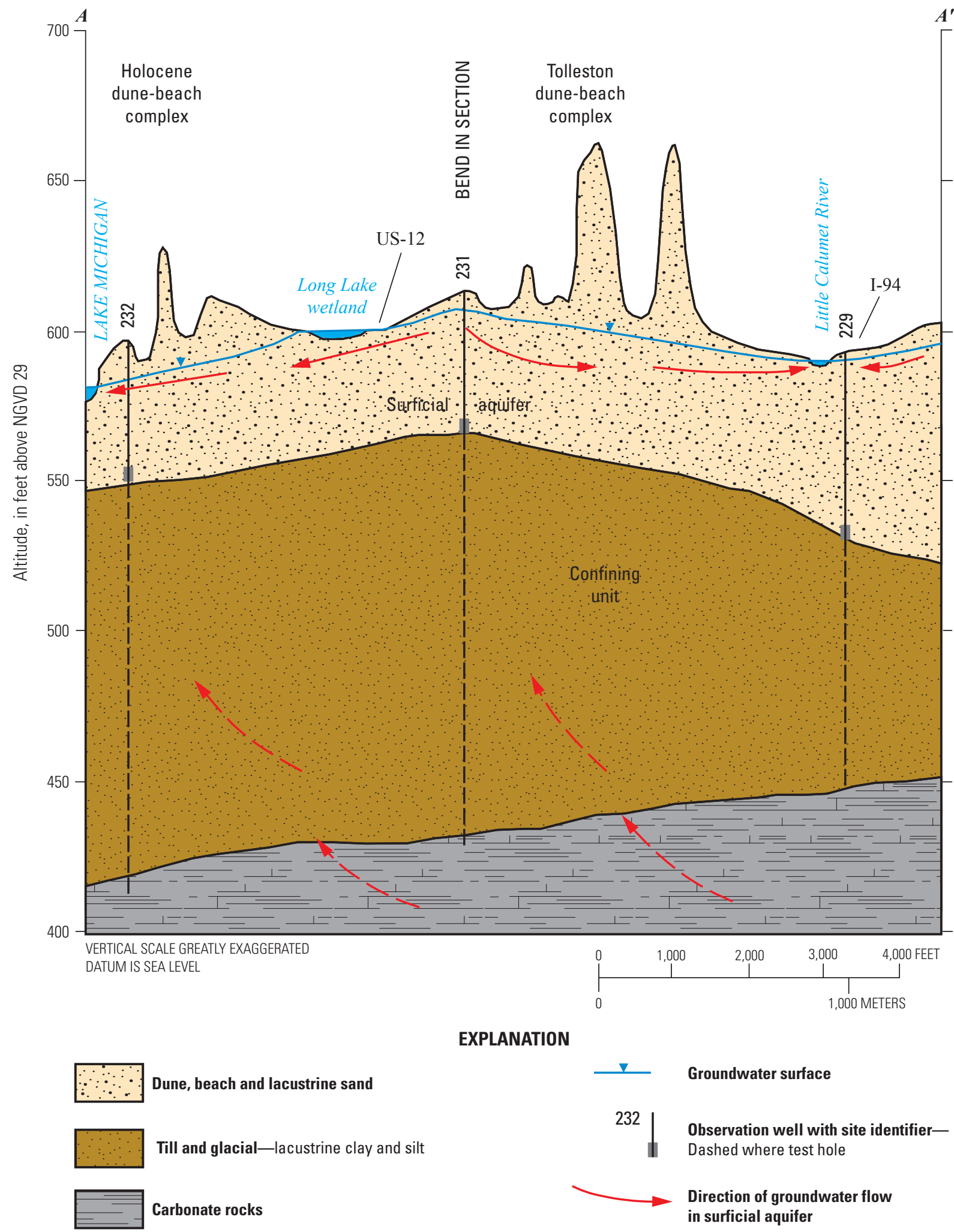

\section{EXPLANATION}

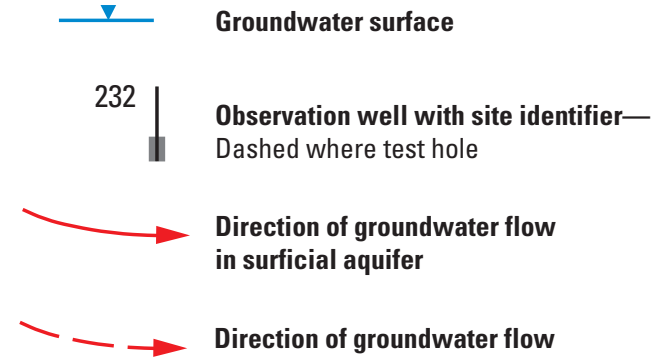

Figure 6. Hydrogeologic section $A-A^{\prime}$ showing the surficial aquifer, confining unit, and underlying carbonate bedrock (modified from Shedlock and others 1994). Section trace is shown in fig. 2. 


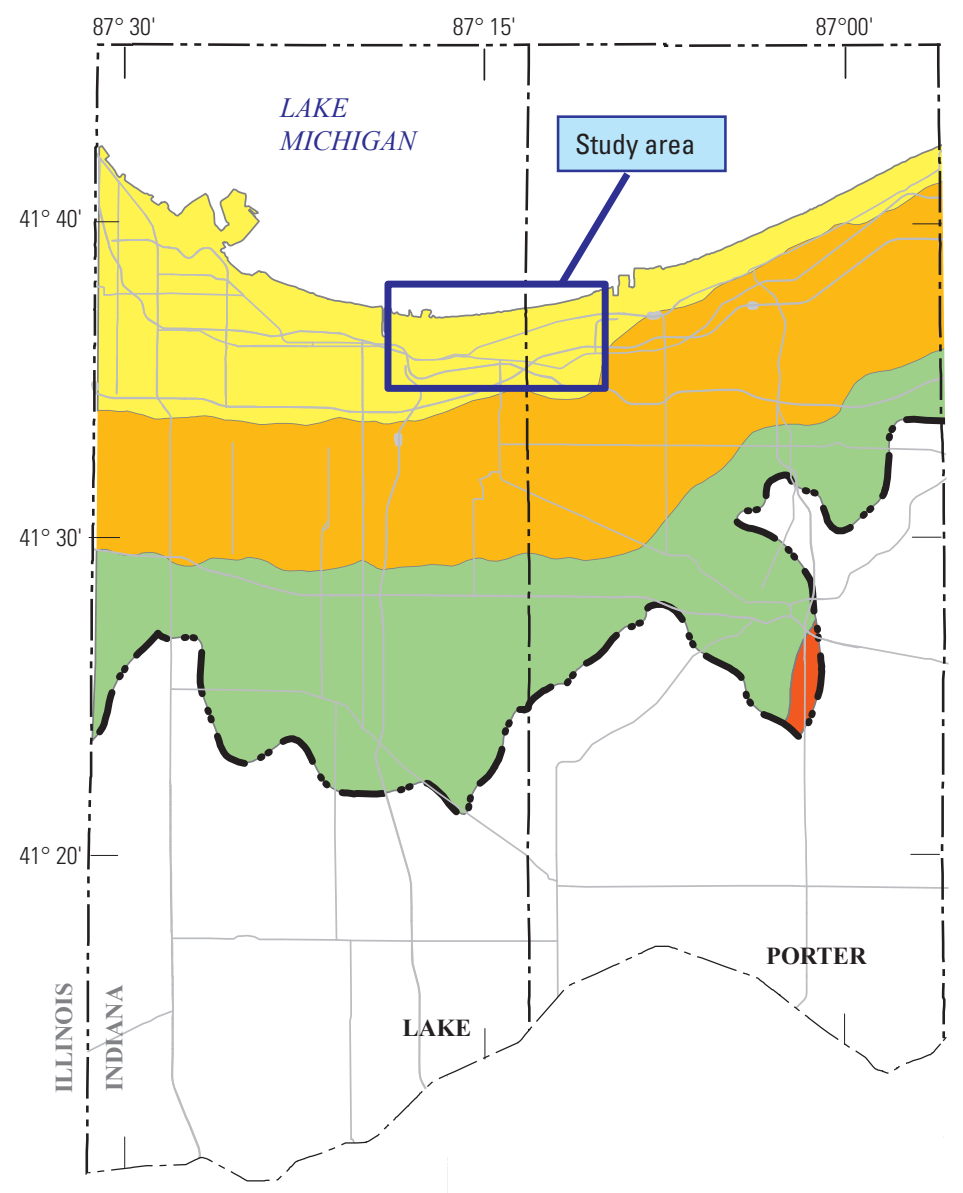

\section{EXPLANATION}

Aquifer systems of the Lake Michigan Basin-

Approximate extent as mapped by Beaty (1994)

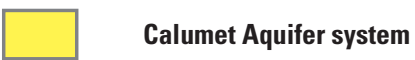

Lacustrine Plain Aquifer system

Valparaiso Moraine Aquifer system

Valparaiso Outwash Apron Aquifer system

- Lake Michigan basin boundary

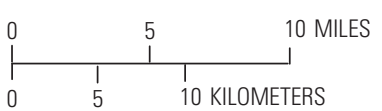

Base from U.S. Geological Survey digital data 1983, 1:100,000

Universal Transverse Mercator projection, Zone 16

Standard parallel $0^{\circ}$ (Equator), Central meridian $87^{\circ} \mathrm{W}$

North American Datum 1983

Figure 7. Unconsolidated aquifer systems in the Lake Michigan region and the study area, northwestern Indiana. Definitions of aquifer-system characteristics can be found in Beaty (1994, pl. 2).

Table 1. Lithostratigraphy of the study area in the context of northwestern Indiana hydrogeologic units.

\begin{tabular}{llc}
\hline \multicolumn{1}{c}{ Lithostratigraphic descriptions } & \multicolumn{1}{c}{ Hydrogeologic-framework designation } \\
\cline { 2 - 3 } $\begin{array}{l}\text { Fine- to medium-grained dune, beach, and lacustrine sands and gravels } \\
\text { (of Holocene and Pleistocene age) }\end{array}$ & $\begin{array}{c}\text { Surficial aquifer } \\
\text { others (1994) }\end{array}$ & Calumet Aquifer system. \\
$\begin{array}{l}\text { Glacial and lacustrine sands of Pleistocene age, with interbedded clays } \\
\text { and silts, including tills of the Lake Border Moraine }\end{array}$ & $\begin{array}{l}\text { Confining units } \\
\text { Subtill aquifer }\end{array}$ & Lacustrine Plain Aquifer system. \\
& $\begin{array}{l}\text { Confining units } \\
\text { Shale and carbonate rocks of Devonian and Silurian age }\end{array}$ & $\begin{array}{l}\text { Basal sand aquifer } \\
\text { Bedrock aquifer }\end{array}$ \\
\hline
\end{tabular}




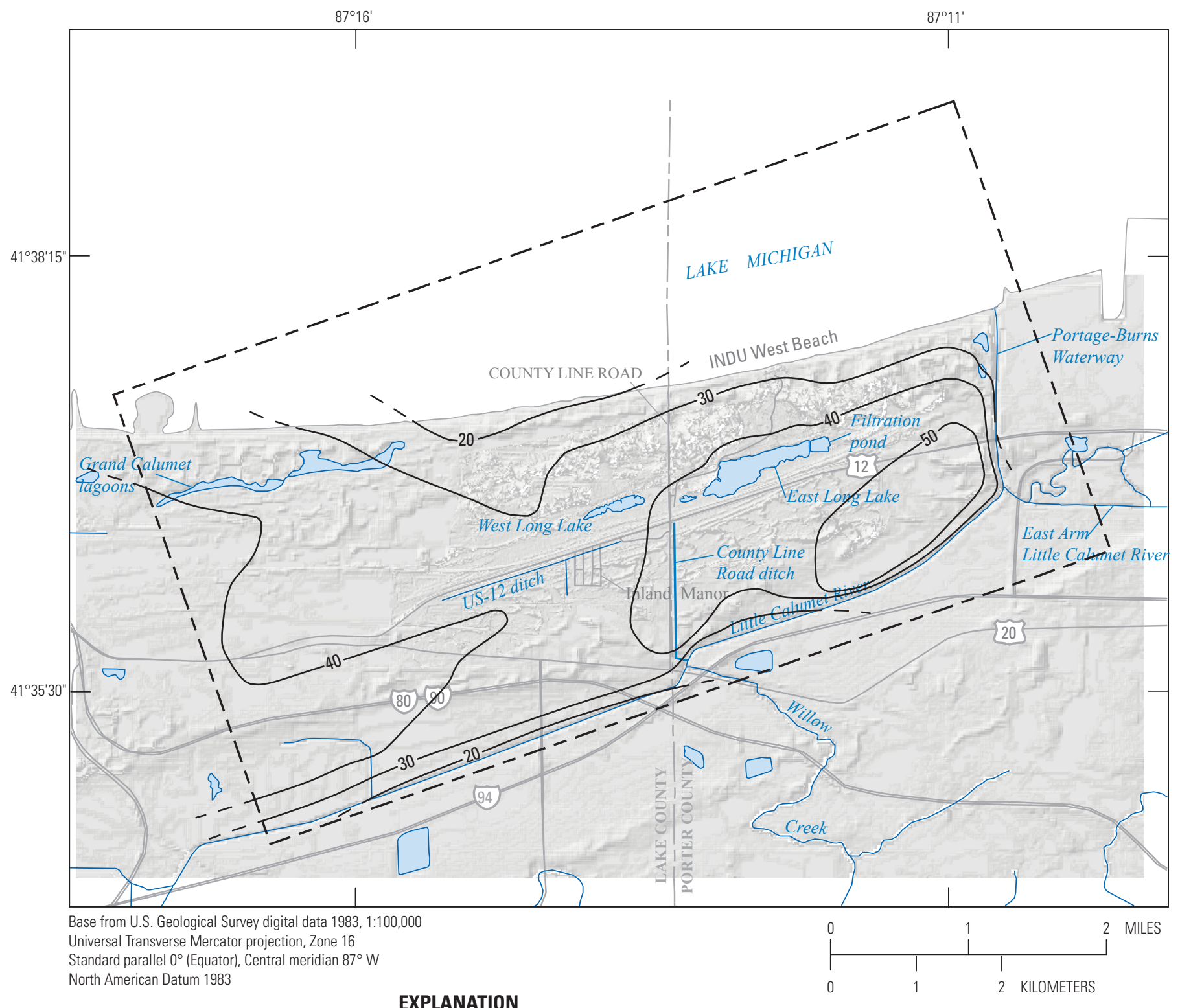

\section{EXPLANATION}

$--50-\begin{aligned} & \text { Saturated-thickness contour - Shows approximate saturated thickness of the } \\ & \text { surficial aquifer on October 16, 2002. Contour interval } 20 \text { feet. Dashed where approximately located }\end{aligned}$

- - Model study area

Figure 8. Saturated thickness of the surficial aquifer on October 16, 2002, in the Long Lake area. 


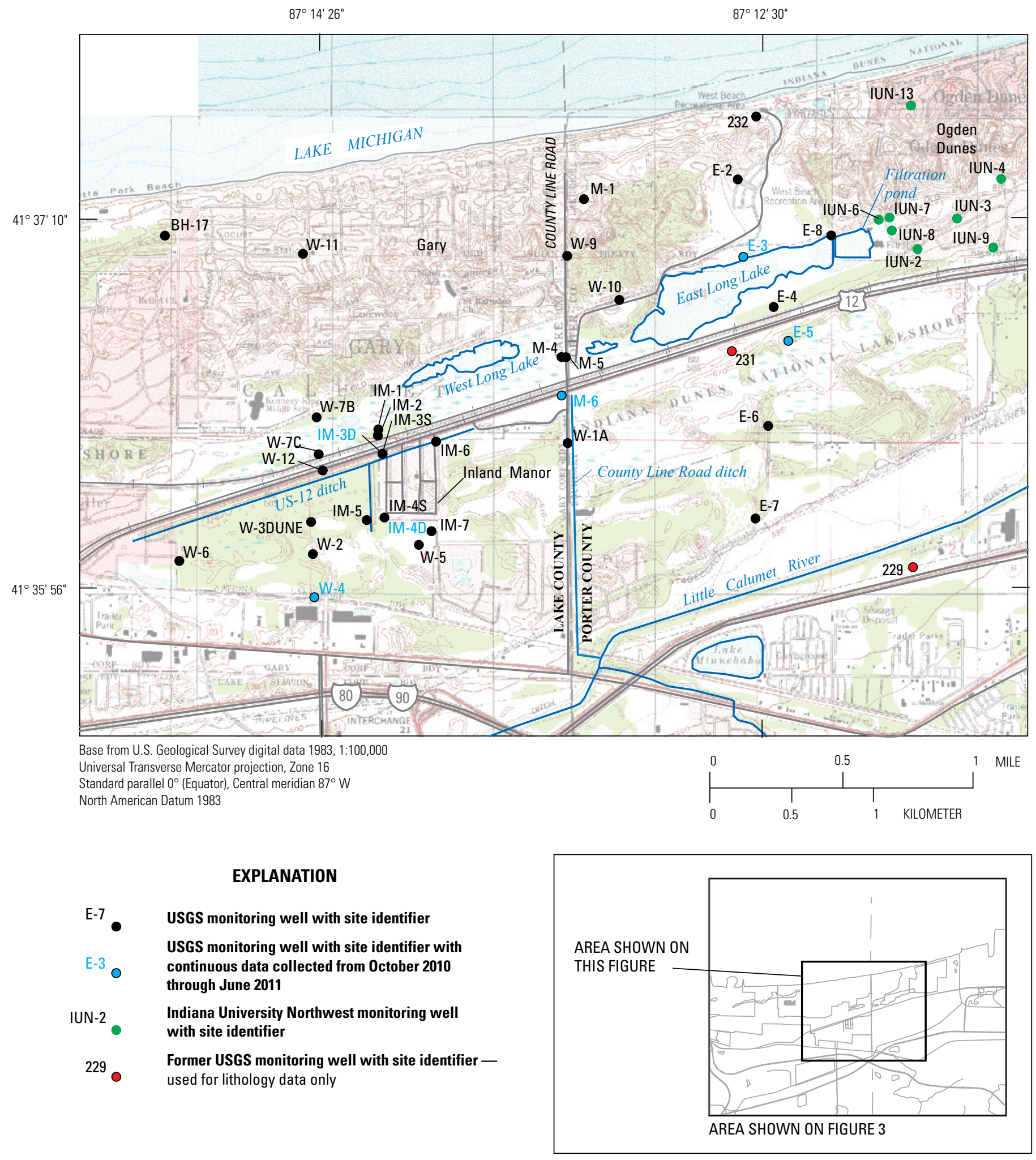

Figure 9. Monitoring wells in the Long Lake area. 


\section{Methods of Investigation}

A data-collection network was installed in the study area to measure both discrete and continuous groundwater and surface-water altitudes and streamflow. Groundwater flow modeling relied on these data and hydrogeologic data from previous investigations. Most of the hydrogeologic interpretations in this report are based on data collected from sites shown in figures 3 and 9, particularly the following:

- Lithologic or discrete water-level data collected from 23 monitoring wells installed for this study between June 2001 and December 2002 and between October 2010 and September 2011 (table 2).

- Lithologic or water-level data collected from 14 monitoring wells installed before 1997 for previous studies in the area (table 2).

- Continuous record water-level data collected from 6 monitoring wells from October 2010 through June 2011.

- Discrete water-level data from 8 monitoring wells previously installed and operated in Ogden Dunes by Indiana University Northwest between October 2010 and March 2011 (Erin Argyilan, Indiana University Northwest, written commun., 2010).

- Surface-water stage (water level) or discharge obtained from 26 surface-water monitoring sites established for this study between June 2001 and December 2010 and at 1 USGS streamgage (table 3 ).

Lithology as referred to in this report is defined by the relative grain size or texture of geologic materials encountered during drilling. "Continuous record" indicates data collected hourly or more frequently. "Discrete data" indicates measurements made occasionally and not on a set time period.

These data were augmented by lithologic information from approximately 100 records from the Water Well Record Database maintained by the Indiana Department of Natural Resources, Division of Water (Indiana Department of Natural Resources, 2002).

All methods used for drilling, finishing, and developing monitoring wells installed for this study were consistent with USGS procedures and techniques as described in Holmes and others (2001). Power-augered wells were installed with a rotary-type drilling rig using 4-1/4-in. hollow-stem continuous-flight augers. Hand-driven wells were installed by using a 85-lb fencepost-type driver. All monitoring wells were composed of 2-in.-inside-diameter PVC plastic or stainless steel casings and screens (table 2). Wells in the Ogden Dunes network (fig. 9) are hand-driven wells that were established and measured by faculty and students of Indiana University Northwest (Dr. Erin Argyilan, Indiana University Northwest, written commun., 2010).
Measuring points for most surface-water-stage measurement sites (table 3 ) consisted of painted or lightly chiseled marks on bridge guardrails or culvert tops that facilitated consistent tape measurements down to the water surface. In several locations where no bridge or culvert was available, a 1/2-in.-diameter, 8-ft-long steel rod or 6-ft-long fencepost was driven into the surficial sediments to a depth of about 5 to $6 \mathrm{ft}$. The top of the exposed steel rod served as the measuring point.

Vertical control on measuring-point altitudes was established with an automatic (pendulum) level and leveling rod by using standard methods and procedures (U.S. Geological Survey, 1966). Measuring-point altitudes for all monitoring wells and most surface-water stage-measurement sites in the study area (tables 2 and 3) were tied to a single first-order benchmark by using a starting altitude referenced to NAVD 88. Measuring-point altitudes derived by using this benchmark are considered accurate to $\pm 0.01 \mathrm{ft}$. The measuring-point altitude for surface-water stage-measurement site B-20 (fig. 3, table 3) was tied to an Indiana Department of Transportation benchmark on the wing wall of the US-20 bridge across the Little Calumet River and was referenced to NGVD 29. The measuring-point altitude for this site was converted from the NGVD 29 to NAVD 1988 by using the National Geodetic Survey VERTCON tool (Mulcare, 2004). Well-construction information and measuring-point altitudes for wells in the Ogden Dunes network were adjusted by using the relative difference in altitude between USGS Well E-8 and well IUN-6 to establish the difference in vertical datums used to survey each network (fig. 9). This difference was then applied to each well in the Ogden Dunes network to calculate measuring-point altitudes referenced to the same datum across the study area.

Water levels in monitoring wells and at surface-water stage-measurement sites were measured with either a graduated steel or electric tape. All water-level measurements are considered accurate to $\pm 0.01 \mathrm{ft}$ and were made by using standard methods and procedures (Holmes and others, 2001). The stage values for the level of Lake Michigan in this report were obtained at a National Oceanic and Atmospheric Administration (NOAA) monitoring site at Calumet Harbor, Illinois (Ill.) (National Oceanic and Atmospheric Administration, 2011), approximately $18 \mathrm{mi}$ northwest of the study area.

Continuous record water-level data were measured at 15-minute increments from October 2010 through June 2011 at six sites within the study area (fig. 9). Transducers were installed in wells E-3, E-5, M-6, IM-3D, W-4, and IM-4D. Accuracy of the transducer measurements of water levels was approximately $\pm 0.01 \mathrm{ft}$. Transducer measurements of water levels were adjusted for mechanical drift by linearly averaging the difference between the transducer and electric tape measurements over the period between electric tape measurements. 


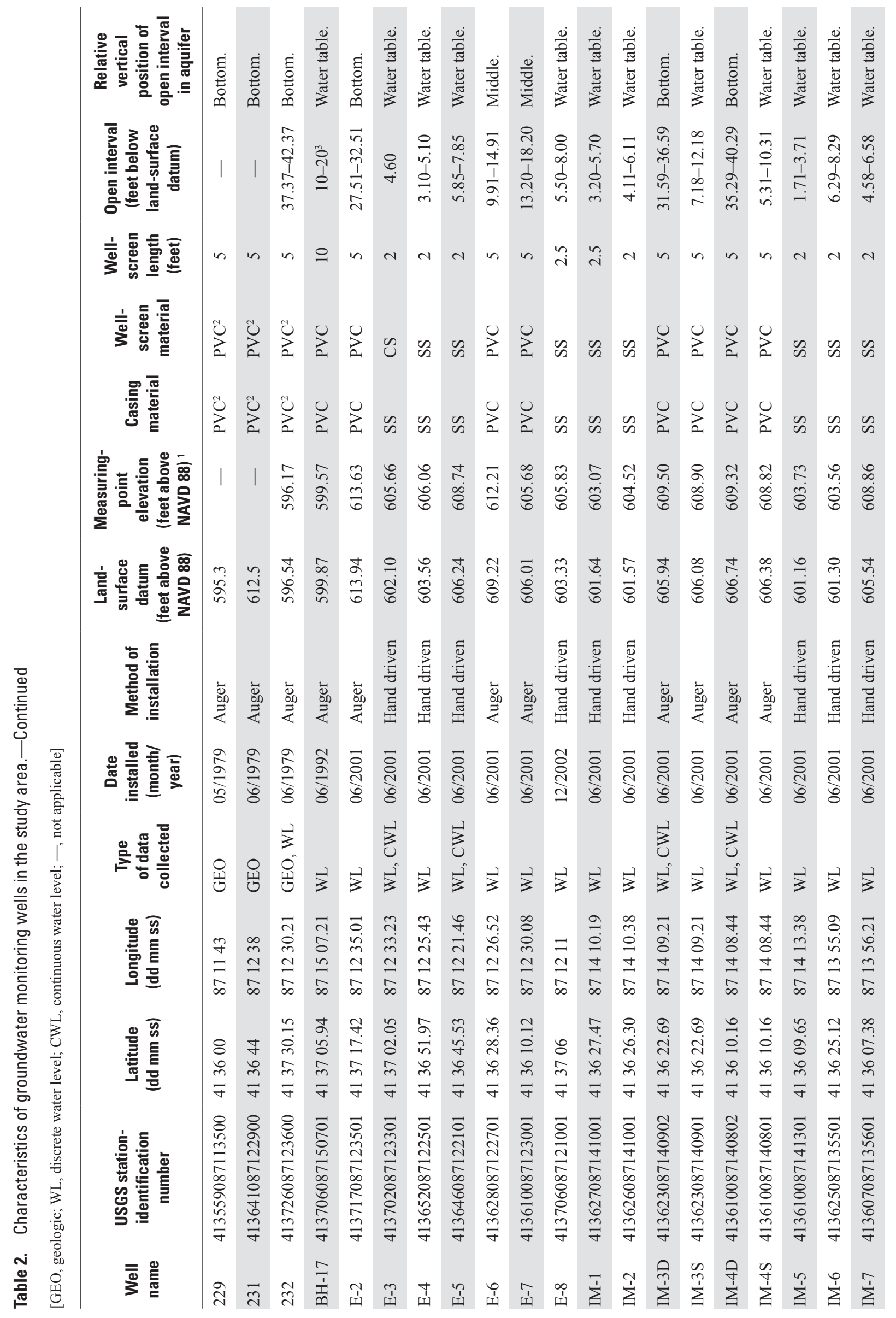




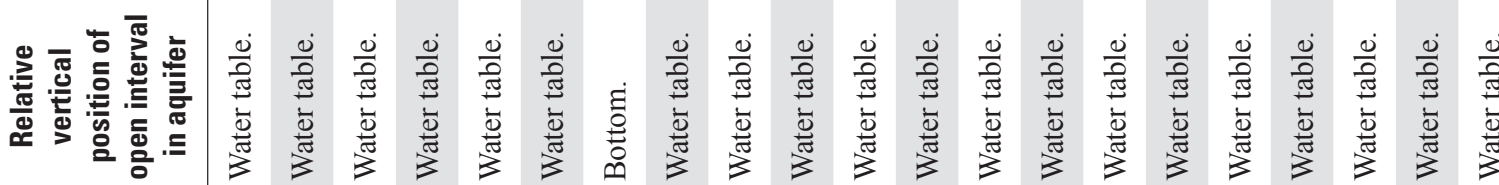

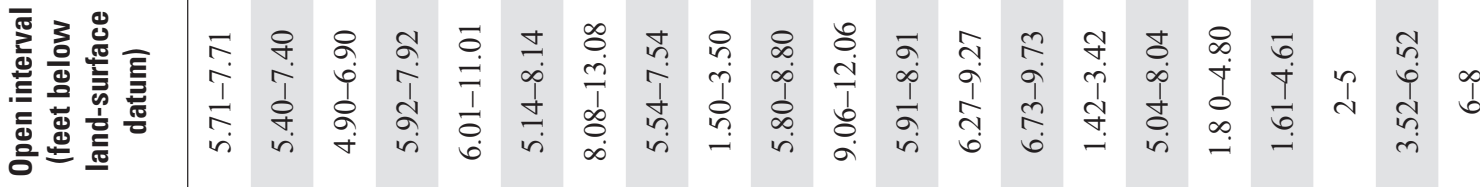

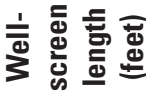
言离

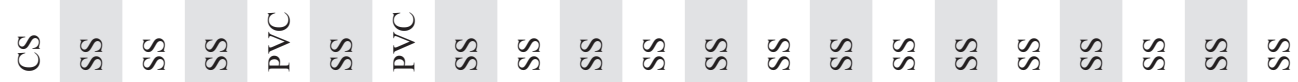
产带

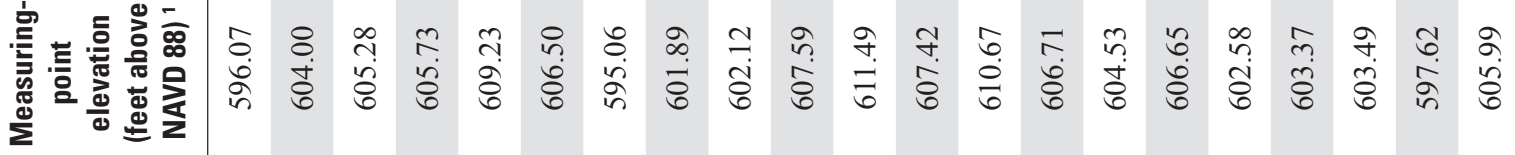

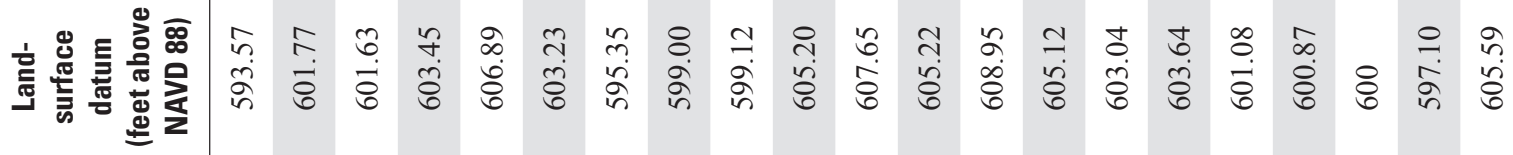

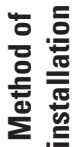

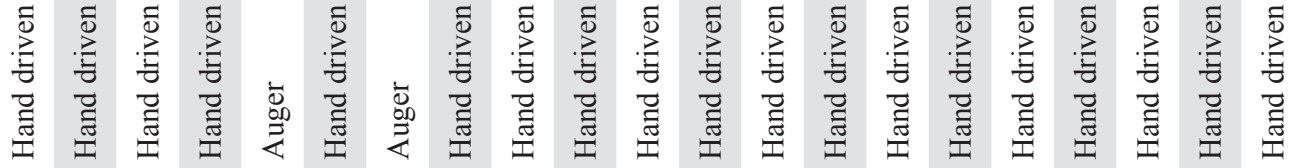

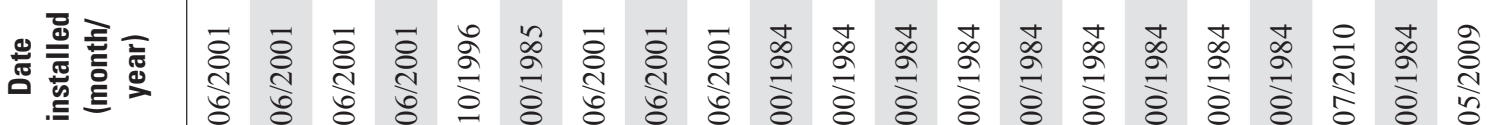
焉焉焉

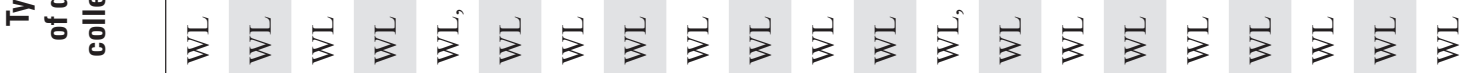

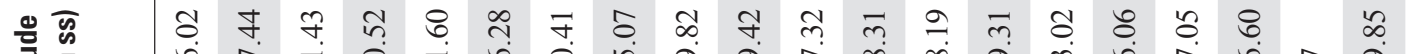

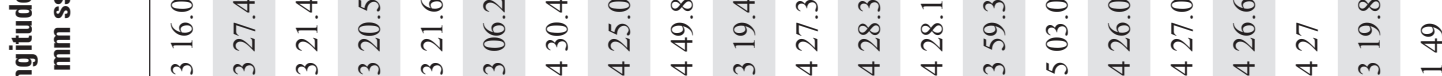

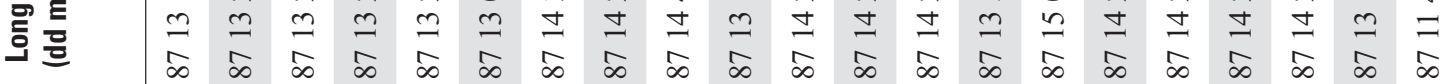
@

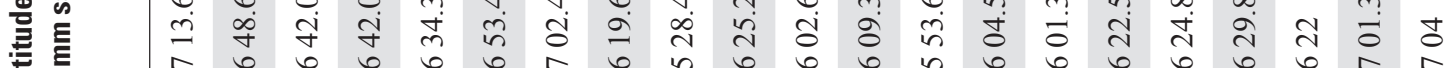

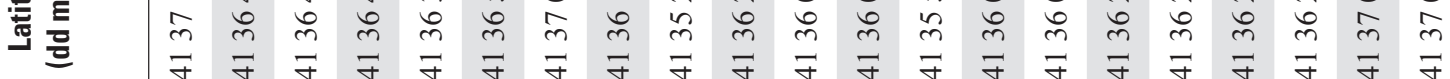

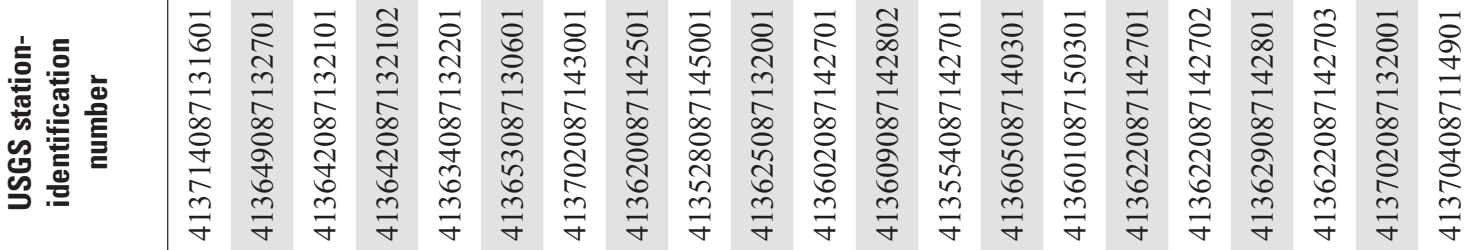

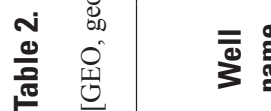

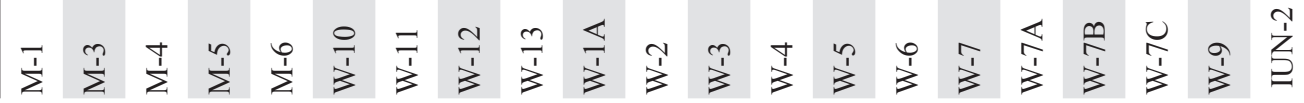




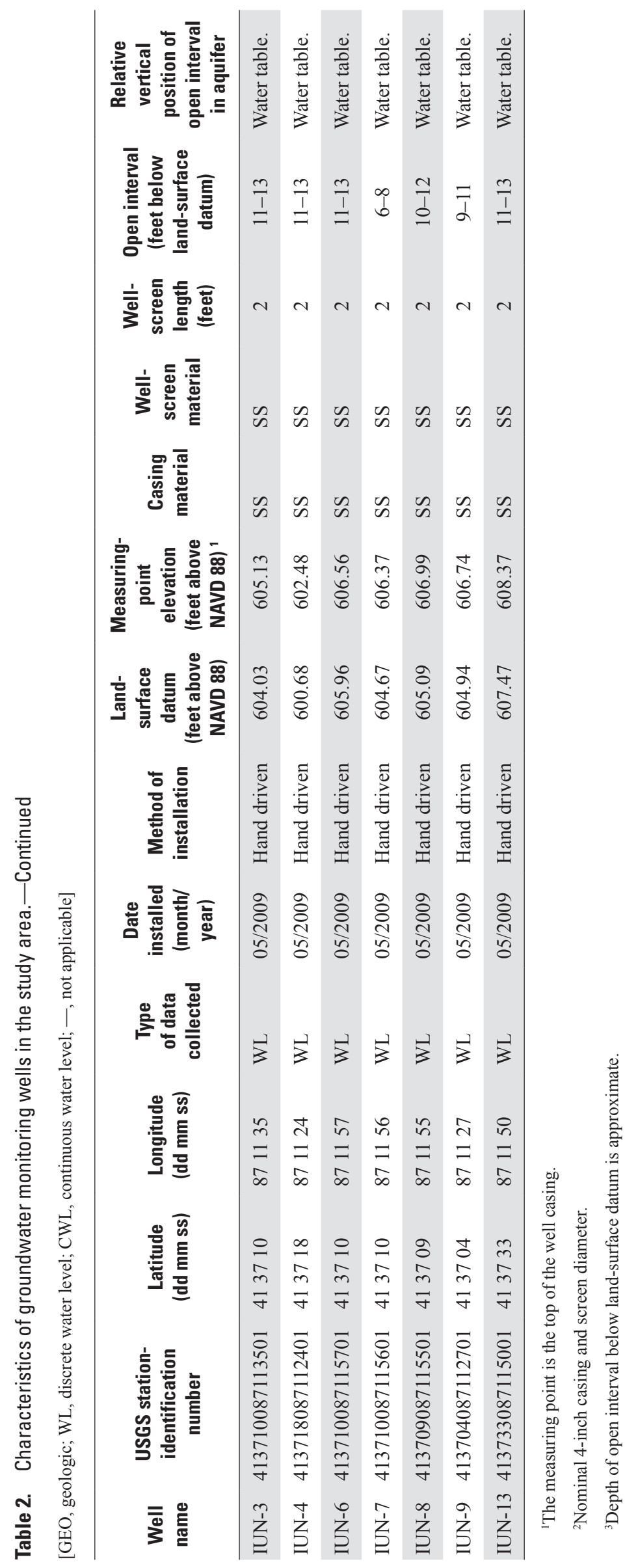




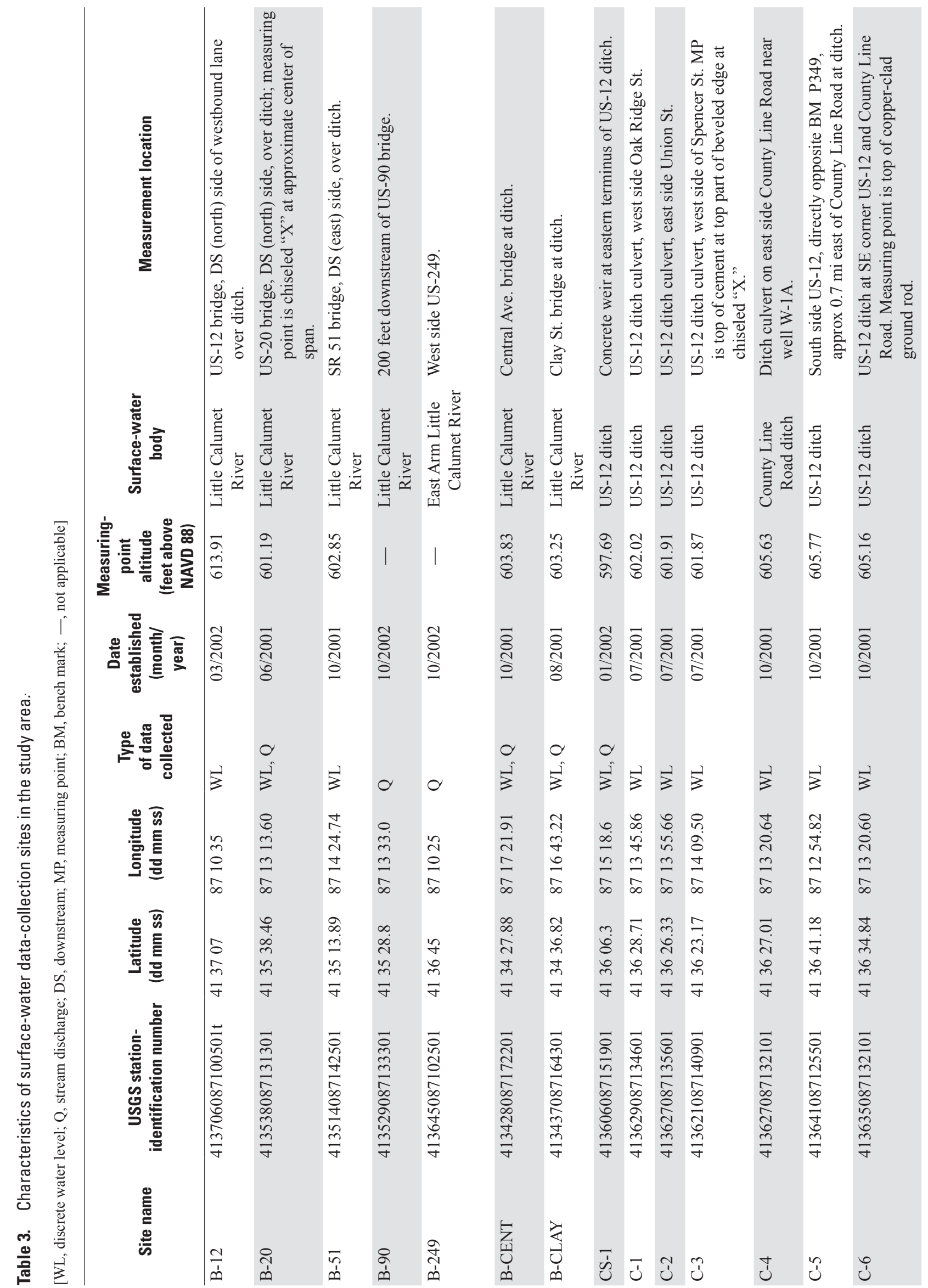




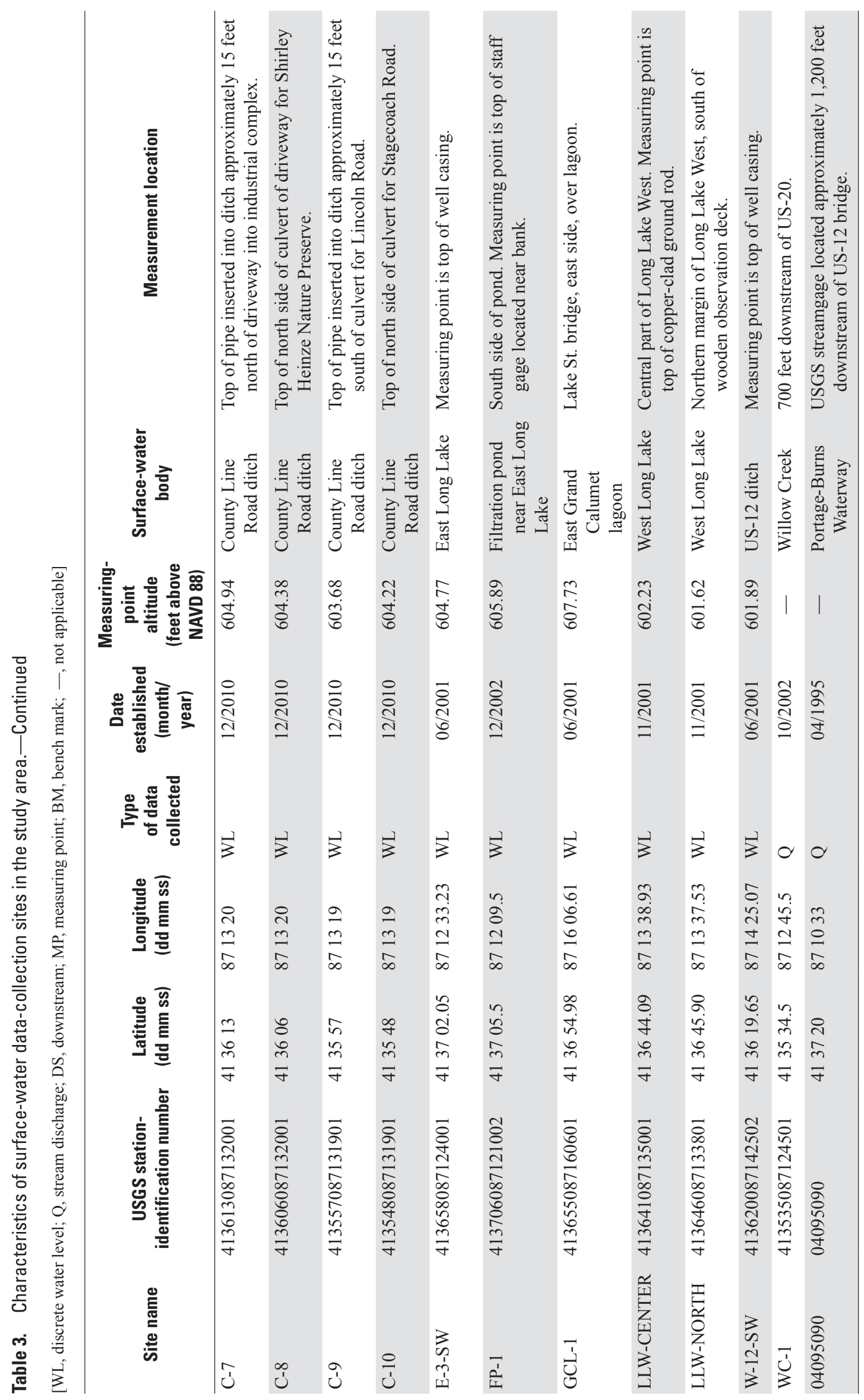


Stream discharge was measured at three sites on the Little Calumet River, one site on the East Arm Little Calumet River, and one site on Willow Creek in 2002 and two sites on the Little Calumet River in 2010 and was calculated from stream stage data at the USGS streamgage on the PortageBurns Waterway, station number 04095090 (fig. 3). Discharge data collected in 2002 and the methods and procedures used to obtain them are published in Morlock and others (2004). Discharge data from the Portage Wastewater Treatment Plant (PWTP) (fig. 3) in 2002 were compiled from reported records for the data-collection period (Ricki Dodd, Plant Manager, Portage Wastewater Treatment Plant, written commun., 2002). Discharge was measured in 2002 and 2011 from US-12 ditch by using a V-notch weir at the western terminus of the ditch (CS-1, fig. 3) in accordance with procedures described by Holmes and others (2001) and in County Line Road ditch in 2011 by using an acoustic Doppler velocimeter approximately $150 \mathrm{ft}$ downstream from site C-10 (fig. 3).

The finite-difference groundwater model code MODFLOW-NWT (Niswonger, 2011) was used to simulate threedimensional groundwater flow in the surficial aquifer. The parameter estimation code UCODE_2005 (Poeter and others, 2005) was used to improve model calibration. Methods used during model construction and calibration are discussed in detail in the section "Simulation of Groundwater Flow and Availability." A particle-tracking post-processing package for MODFLOW was used to generate three-dimensional flow paths with different scenarios of the model for this report. MODPATH computes paths for imaginary particles of water moving through the simulated groundwater system. MODPATH also keeps track of traveltime (although it was not used in this report) by assignment of porosity to cells.

\section{Groundwater Levels and Flow in the Surficial Aquifer}

Generally, the groundwater flow system in the surficial aquifer has east-west-trending water-table mounds that function as groundwater divides underlying the central lowland areas. Groundwater flows laterally away from these divides and generally discharges to the US-12 ditch, East Long Lake, West Long Lake, Lake Michigan to the north, and the Little Calumet River to the south. The hydraulic gradient toward Lake Michigan north of East Long Lake and West Long Lake is relatively steep $(25 \mathrm{ft} / \mathrm{mi}$ ) compared to hydraulic gradients elsewhere in the study area.

Synoptic measurements ${ }^{2}$ of water-level elevation on October 16, 2002 (table 4), during a dry-weather period and on March 8, 2011 (table 5), during a wet-weather period were used to map the water table within the study area and serve as reference periods for the groundwater modeling.

\section{Recharge}

Historical precipitation data are available from two stations near the study area: Ogden Dunes for 1951 through 1989 data and INDU headquarters for 1989 through 2011 (fig. 10) (Midwestern Regional Climate Center, 2010). The Ogden Dunes station was discontinued on May 21, 1989, and relocated to the present INDU site, where data collection resumed on June 1, 1989. Precipitation totals in three of four summer months prior to the October 2002 data collection were lower than typical. Except for August 2002, they were below the median monthly value for the period of record of 57 years and ranged from 0.97 in. in July 2002 to 3.58 in. in August 2002 (fig. 10A). Precipitation totals for January (1.81 in.) and February 2011 (2.92 in.) were greater than the median monthly values for the previous 57 years (fig. 10B). Much of the precipitation during these months fell as snow, and snowpack depths were as great as $20 \mathrm{in}$. Increased temperatures in late February and early March led to the melting of the snow in the weeks prior to the 2011 water-level data collection (fig. 11).

\footnotetext{
${ }^{2}$ Synoptic measurements involve data collection at multiple sites in an area over a short period (often a single day) to characterize a selected seasonal or hydrologic condition.
} 
Table 4. Water-level measurements made on October 16, 2002.

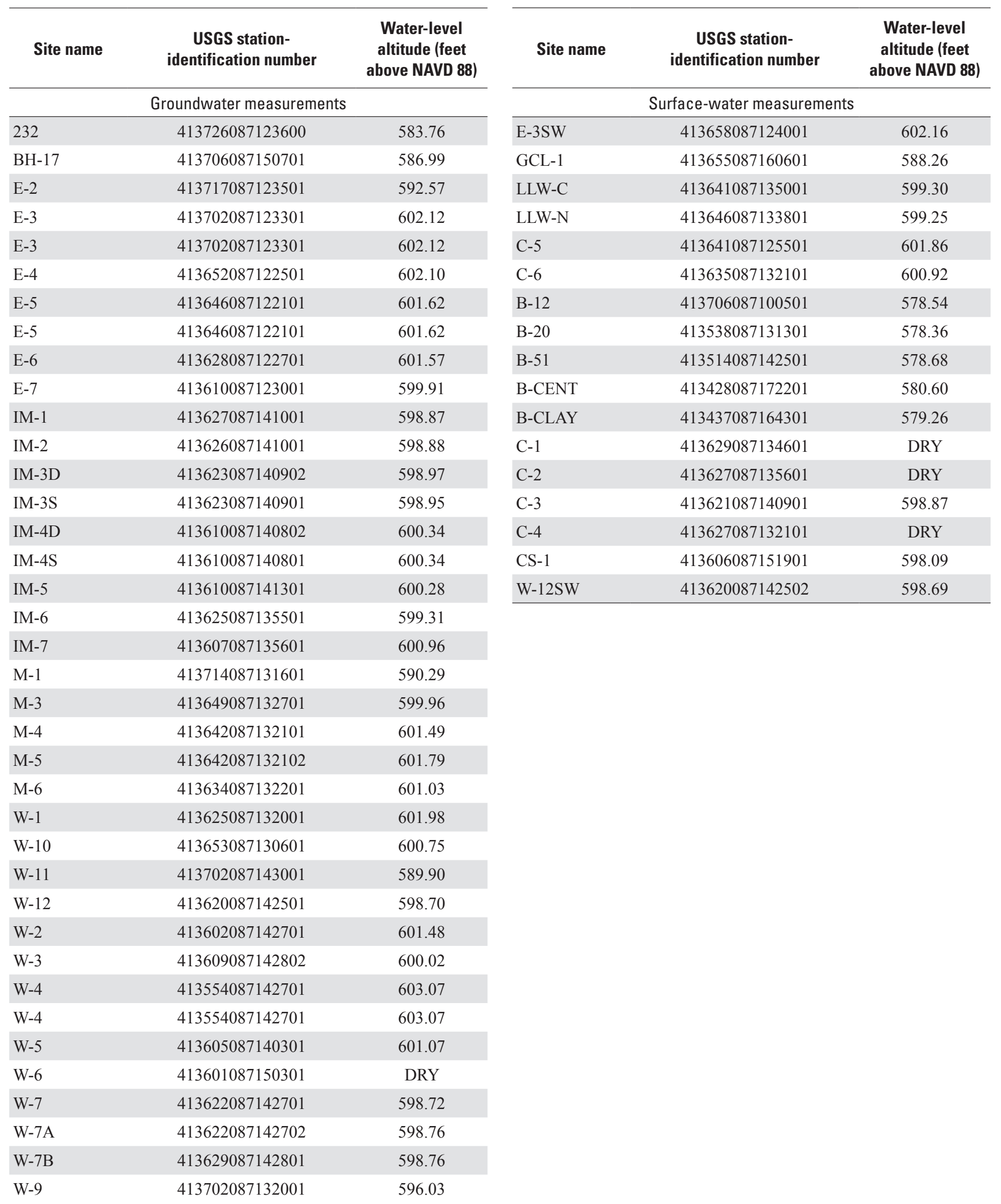


Table 5. Water-level measurements made on March 8, 2011.

\begin{tabular}{|c|c|c|c|c|c|}
\hline Site name & $\begin{array}{c}\text { USGS station-identification } \\
\text { number }\end{array}$ & $\begin{array}{c}\text { Water-level } \\
\text { altitude (feet } \\
\text { above NAVD 88) }\end{array}$ & Site name & $\begin{array}{c}\text { USGS station-identification } \\
\text { number }\end{array}$ & $\begin{array}{c}\text { Water-level } \\
\text { altitude (feet } \\
\text { above NAVD 88) }\end{array}$ \\
\hline \multicolumn{3}{|c|}{ Groundwater measurements } & \multicolumn{3}{|c|}{ Surface-water measurements } \\
\hline 232 & 413726087123600 & 584.14 & FP-1 & 413706087121002 & 602.71 \\
\hline BH-17 & 413706087150701 & 587.58 & GCL-1 & 413655087160601 & 589.33 \\
\hline E-2 & 413717087123501 & 593.45 & C-5 & 413641087125501 & 604.34 \\
\hline E-6 & 413628087122701 & 603.78 & C-6 & 413635087132101 & 604.38 \\
\hline E-7 & 413610087123001 & 599.90 & B-12 & 413706087100501 & 577.16 \\
\hline E-8 & 413706087121001 & 602.50 & B-20 & 413538087131301 & 580.20 \\
\hline IM-2 & 413626087141001 & 602.43 & B-51 & 413514087142501 & 581.10 \\
\hline IM-3S & 413623087140901 & 602.35 & B-CLAY & 413437087164301 & 583.10 \\
\hline IM-4S & 413610087140801 & 604.62 & $\mathrm{C}-1$ & 413629087134601 & 603.73 \\
\hline IM-5 & 413610087141301 & 604.00 & $\mathrm{C}-10$ & 413548087131901 & 602.05 \\
\hline IM-6 & 413625087135501 & 604.00 & $\mathrm{C}-2$ & 413627087135601 & 603.77 \\
\hline IM-7 & 413607087135601 & 603.31 & $\mathrm{C}-3$ & 413621087140901 & 602.17 \\
\hline IUN-13 & 413733087115001 & 601.41 & $\mathrm{C}-4$ & 413627087132101 & 604.13 \\
\hline IUN-2 & 413704087114901 & 600.53 & C-7 & 413613087132001 & 604.09 \\
\hline IUN-3 & 413710087113501 & 597.04 & C- 8 & 413606087132001 & 603.02 \\
\hline IUN-4 & 413718087112401 & 593.24 & C-9 & 413557087131901 & 602.52 \\
\hline IUN-6 & 413710087115701 & 600.77 & CS-1 & 413606087151901 & 598.35 \\
\hline IUN-7 & 413710087115601 & 598.66 & & & \\
\hline IUN-8 & 413709087115501 & 596.49 & & & \\
\hline IUN-9 & 413704087112701 & 595.56 & & & \\
\hline M-1 & 413714087131601 & 591.25 & & & \\
\hline M-4 & 413642087132101 & 602.42 & & & \\
\hline M-5 & 413642087132102 & 602.76 & & & \\
\hline W-1 & 413625087132001 & 604.25 & & & \\
\hline W-10 & 413653087130601 & 602.39 & & & \\
\hline W-11 & 413702087143001 & 591.57 & & & \\
\hline W-12 & 413620087142501 & 601.76 & & & \\
\hline W-2 & 413602087142701 & 605.19 & & & \\
\hline W-3 & 413609087142802 & 603.73 & & & \\
\hline W-4 & 413554087142701 & 607.77 & & & \\
\hline W-4 & 413554087142701 & 607.77 & & & \\
\hline W-5 & 413605087140301 & 604.28 & & & \\
\hline W-6 & 413601087150301 & 602.30 & & & \\
\hline $\mathrm{W}-7 \mathrm{C}$ & 413622087142703 & 602.35 & & & \\
\hline W-9 & 413702087132001 & 597.14 & & & \\
\hline
\end{tabular}



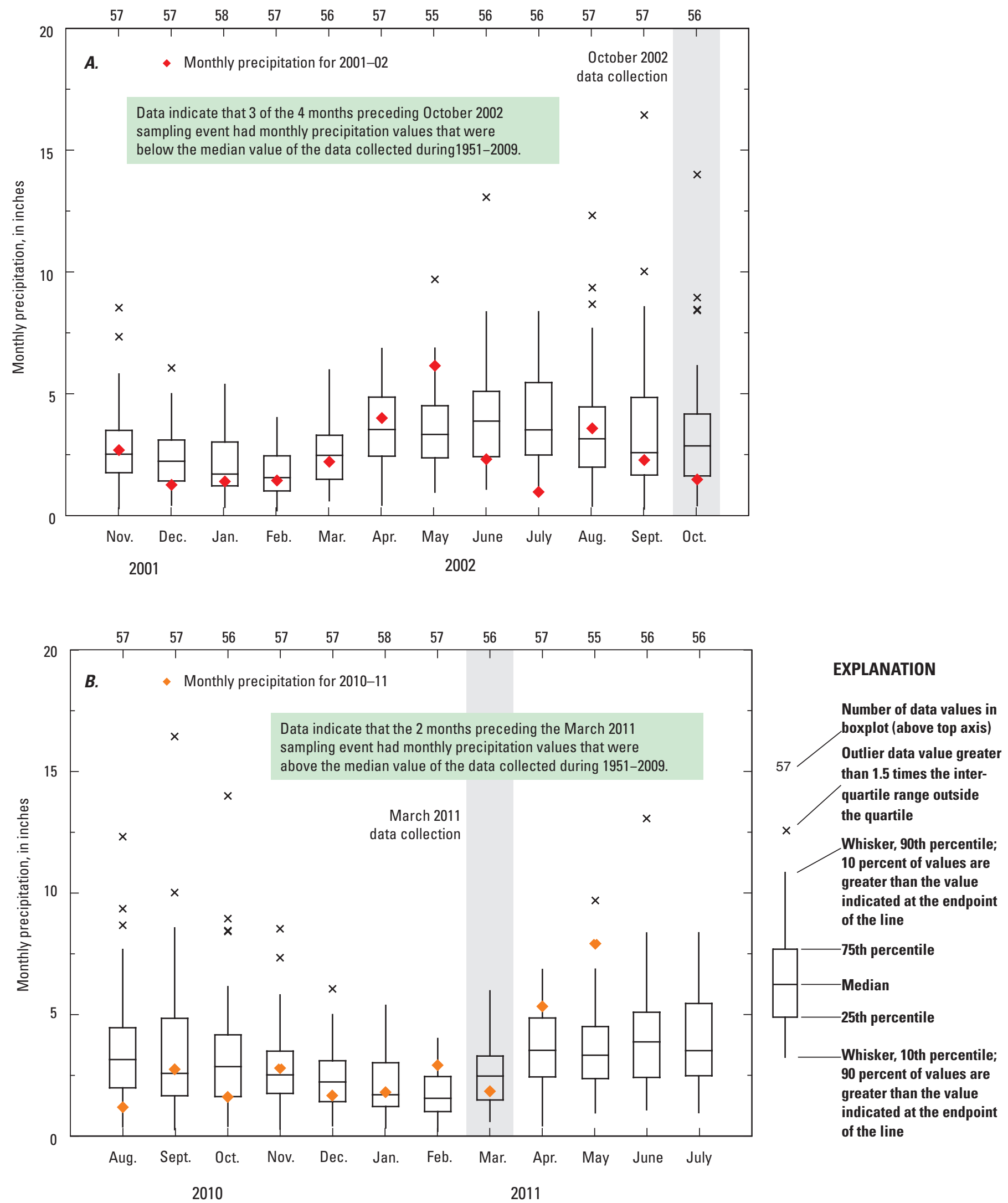

Figure 10. Monthly precipitation statistics for the combined records from the weather stations at Ogden Dunes (1951 through 1989) and Indiana Dunes National Lakeshore, northwestern Indiana (1989 through 2009). A, Precipitation from November 2001 through 0 ctober 2002. B, Precipitation from August 2010 through May 2011. Station locations are shown in fig. 1. 


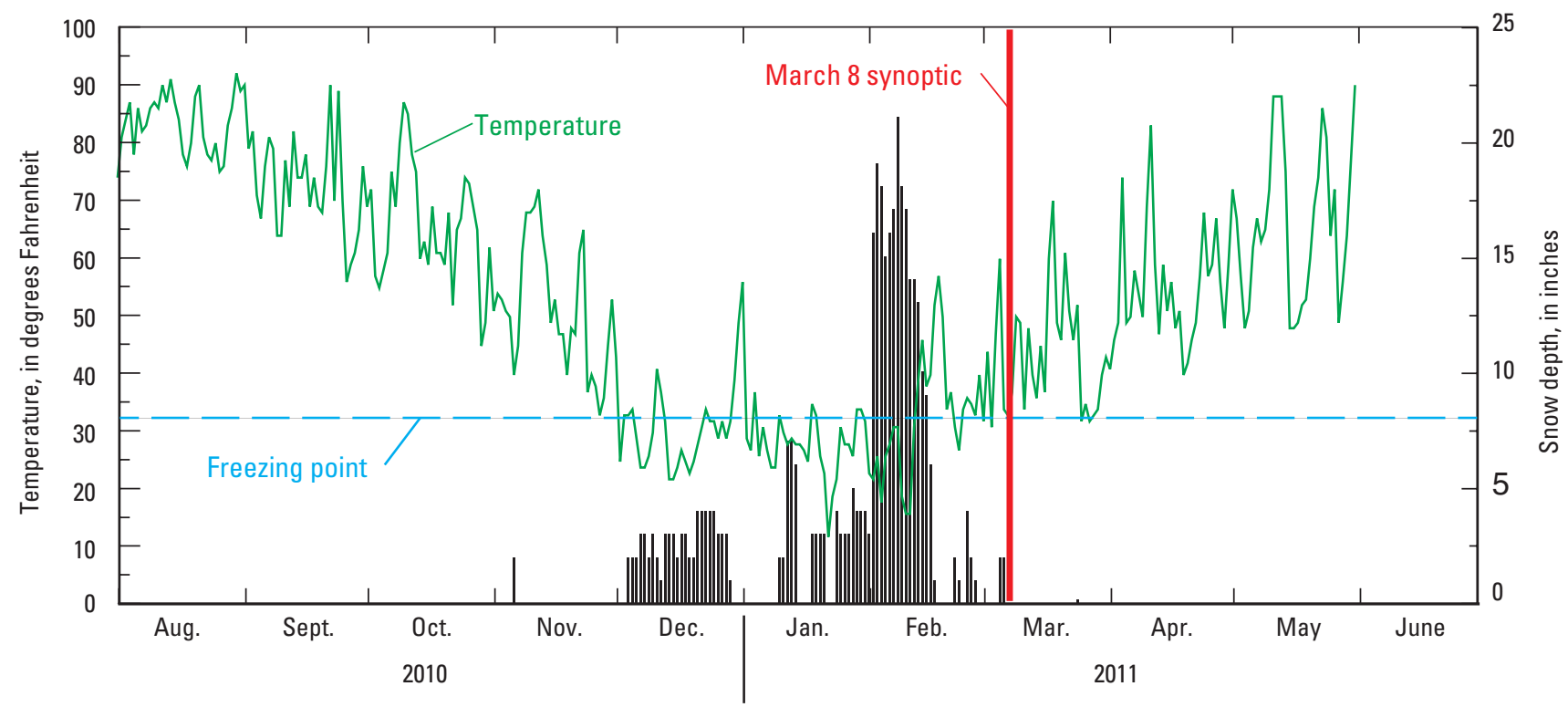

Figure 11. Snow depth and temperature from records from the weather station at Indiana Dunes National Lakeshore, northwestern Indiana, August 2010 through May 2011.

\section{October 2002 Levels and Flow}

During the dry-weather conditions of October 2002, the groundwater divides (fig. 12) generally coincided with interdunal wetland areas in the central part of the study area along the south side of US-12. On the east side of County Line Road, the groundwater divide generally underlay East Long Lake. On the basis of the collected water-level data, water discharged from East Long Lake to the surficial aquifer, and, because it is the highest point in the system, seepage from the backflow pond was an important source of recharge to the surficial aquifer. On the west side of County Line Road, groundwater discharge into US-12 ditch (measured to be $0.26 \mathrm{ft}^{3} / \mathrm{s}$ on October 15, 2002) created a localized depression in the water table predominantly in the area immediately west of West Long Lake. Groundwater flowed north from the divide and discharged to US-12 ditch. Secondary groundwater flow paths were south from a relatively small groundwater divide beneath West Long Lake where groundwater discharged into US-12 ditch, indicating that the US-12 ditch intercepts groundwater that may otherwise discharge into West Long Lake. Groundwater flow paths in the area near eastern parts of West Long Lake tracked north from the divide and into West Long Lake along its southern boundary. Water discharged from the northern boundary of West Long Lake and flowed north toward Lake Michigan.

\section{March 2011 Levels and Flow}

During the wet-weather conditions of March 2011, the groundwater divides generally coincided with wetland areas south of US-12 (fig. 13). On the east side of County Line Road, the groundwater divide was to the south of US-12 and East Long Lake. Groundwater flowed north to the southern margin of East Long Lake and discharged back to the groundwater system along the northern margin of East Long Lake. This differs from the mapped water table from October 2002 and may relate to the discontinued use in 2009 of the filtration pond on the east end of East Long Lake. During this time, surface water also discharged to the groundwater system from the eastern margin of East Long Lake and the filtration pond and flowed east toward Ogden Dunes and the Portage-Burns Waterway. Groundwater flowed north from the divide on the west side of County Line Road and discharged to US-12 ditch. Secondary flow paths may also have tracked south from a relatively small groundwater divide beneath West Long Lake and into US-12 ditch. The hydraulic gradient on County Line Road ditch was relatively flat north of site C-7 (fig. 3) but steepened to the south toward the Little Calumet River. A small watertable high mapped at the northeastern corner of the study area may represent a perched water table associated with a small, isolated wetland. A detailed discussion of the hydraulic gradient along and near the County Line Road ditch is presented later in this report. 


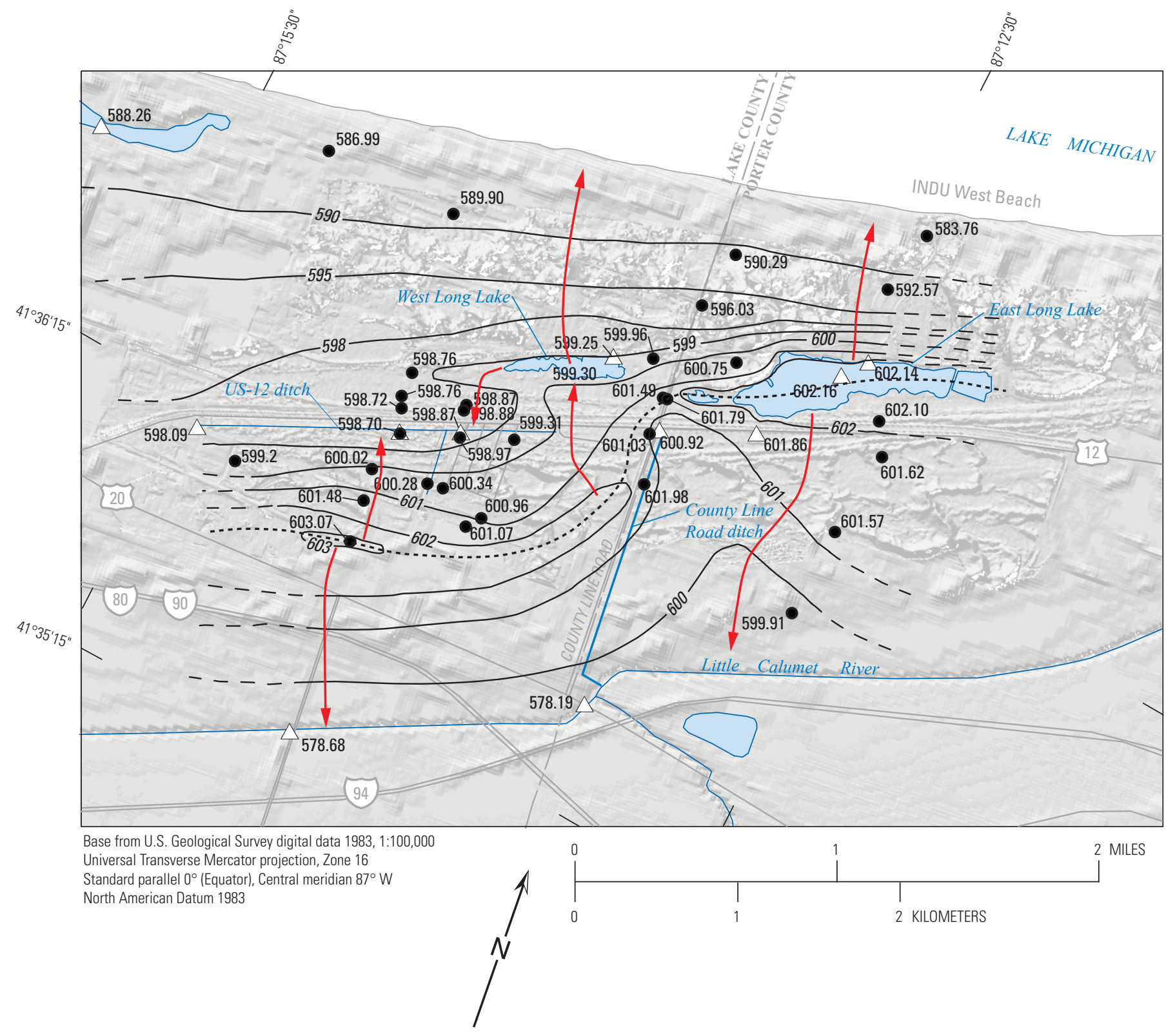

EXPLANATION

\footnotetext{
603.07 Observation well, with water-level altitude on October 16, 2002, in feet above NAVD 88

598.09 Surface-water-level monitoring site, with water-level altitude on October 16, 2002, $\triangle^{598.09} \quad$ in feet above NAVD 88

Water-table contour-Shows approximate altitude of the water table in the surficial aquifer system on October 16, 2002. Contour interval is in feet above NAVD 88. Contour interval variable. Dashed where approximately located

\section{Arrow indicating direction of groundwater flow inferred from water-table contours}

Groundwater divide—Approximate divide in surficial aquifer, October 16, 2002
}

Figure 12. Altitude of the water table in the surficial aquifer measured during dry-weather conditions of 0ctober 16, 2002, in the vicinity of Long Lake, Indiana Dunes National Lakeshore, near Gary, Indiana. 


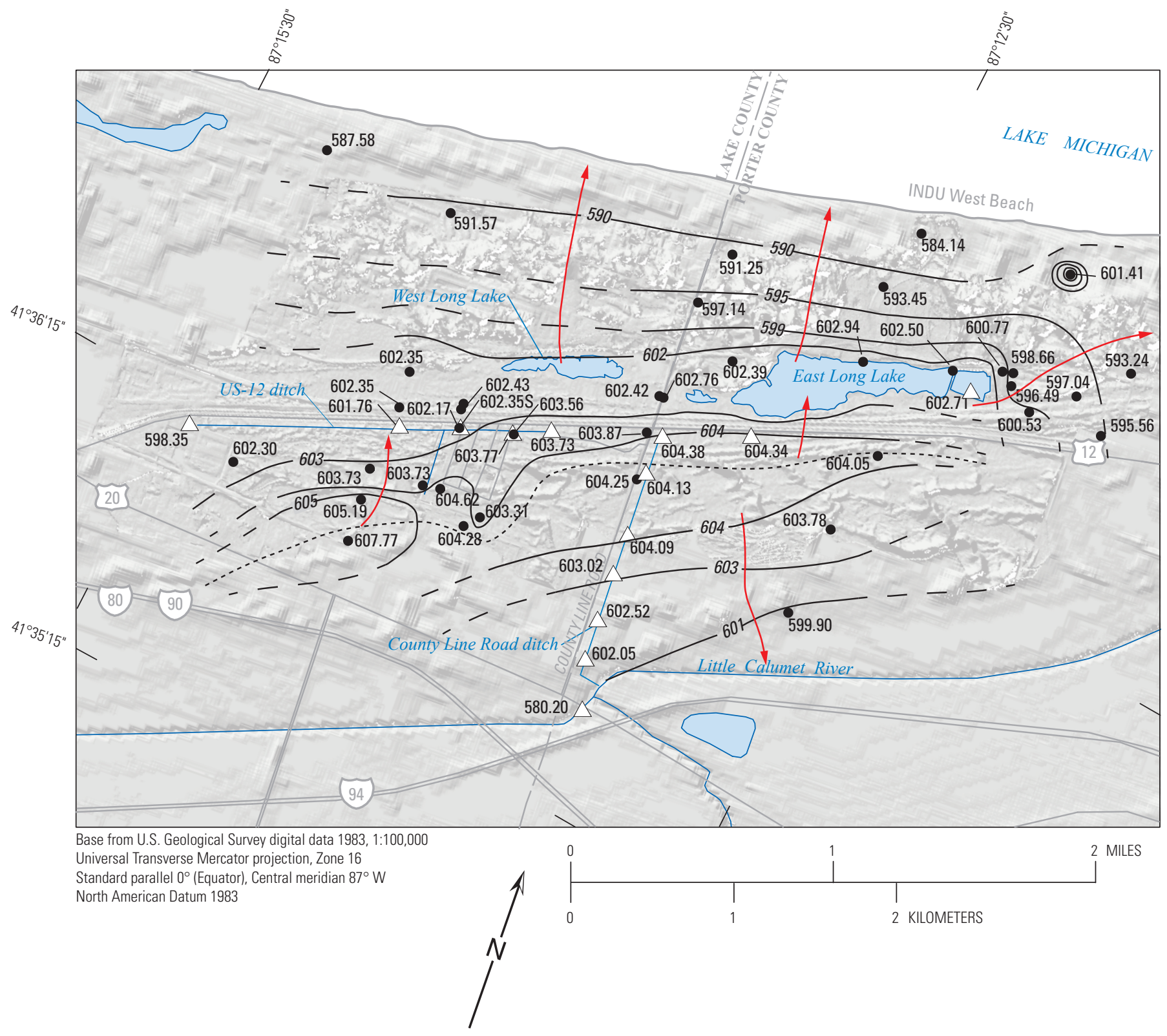

EXPLANATION

602.52 Surface-water-level monitoring site, with water-level altitude on March 8, 2011,

$\triangle$ in feet above NAVD 88

Water-table contour-Shows approximate altitude of the water table in the surficial aquifer system on March 8, 2011. Contour

- - 602- interval is in feet above NAVD 88. Contour interval variable. Dashed where approximately located

\section{Arrow indicating direction of groundwater flow inferred from water-table contours}

Groundwater divide-Approximate divide in surficial aquifer, March 8, 2011

Figure 13. Altitude of the water table in the surficial aquifer measured during wet-weather conditions of March 8, 2011, in the vicinity of Long Lake, Indiana Dunes National Lakeshore, near Gary, Indiana. 
Continuous groundwater-level data indicated recharge to the surficial aquifer in February 2011 from melting and infiltration of the winter snowpack. Continuous groundwater-level data were collected at six of the observation wells (fig. 9) from October 2010 through June 2011. Hydrographs for wells W-4, IM-4D, M-6, E-3, and E-5 (fig. 14) show that water levels gradually increase from the beginning of the period of record through February 2011. Continuous groundwater-level data indicated recharge to the surficial aquifer in February 2011 from melting of the winter snowpack and the infiltration of the meltwater into the surficial aquifer. The gradual increase is followed by a period of relatively stable water levels from the beginning of March to mid-April 2011, followed by another period of water-level increase through the end of the period of record.

The hydrograph for well IM-3D (fig. 14) shows water levels similar to those of well IM-4D, approximately $0.25 \mathrm{mi}$
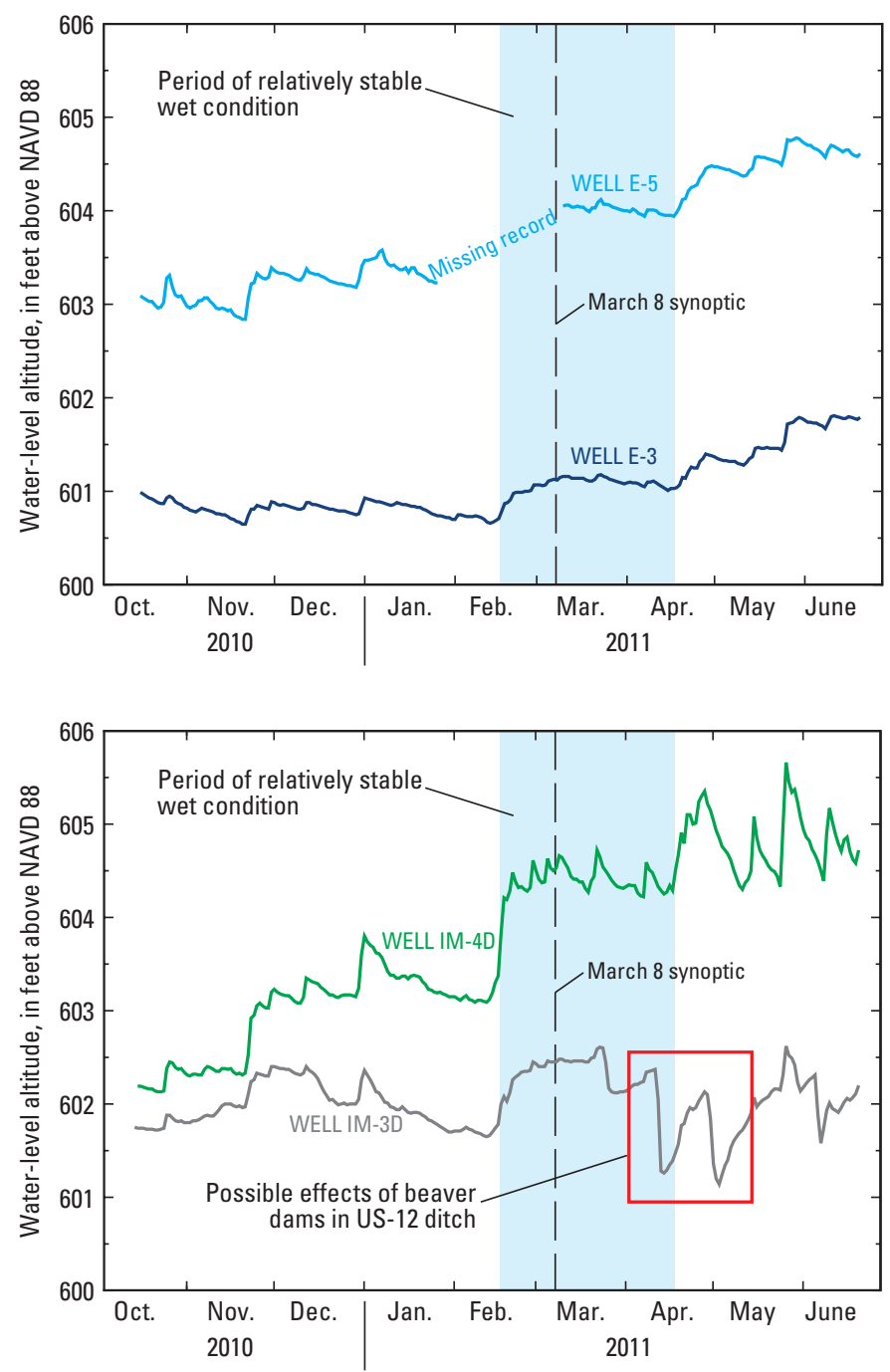

to the south through March 2011. At the beginning of April, the hydrograph for well IM-3D shows two periods of rapid decrease in water level (red box, approximately $1 \mathrm{ft}$ ) and the hydrograph for well IM-4D shows a corresponding gradual increase in water level. These rapid decreases correspond to the failure or overtopping of beaver dams built in the US-12 ditch and indicates the effect these dams can have on the water table surrounding the ditch. Failure of beaver dams allowed water to flow downstream and caused water to drain away from the area surrounding well IM-3D. The location and status of beaver dams built in US-12 ditch was documented by visual surveys during trips to the area from December 2010 through March 2011. Water-level differences between the upstream and downstream side of four beaver dams in US-12 ditch were visually estimated to range from near zero to 2 feet; the differences were included as a feature of the simulation of US-12 ditch in the groundwater model.
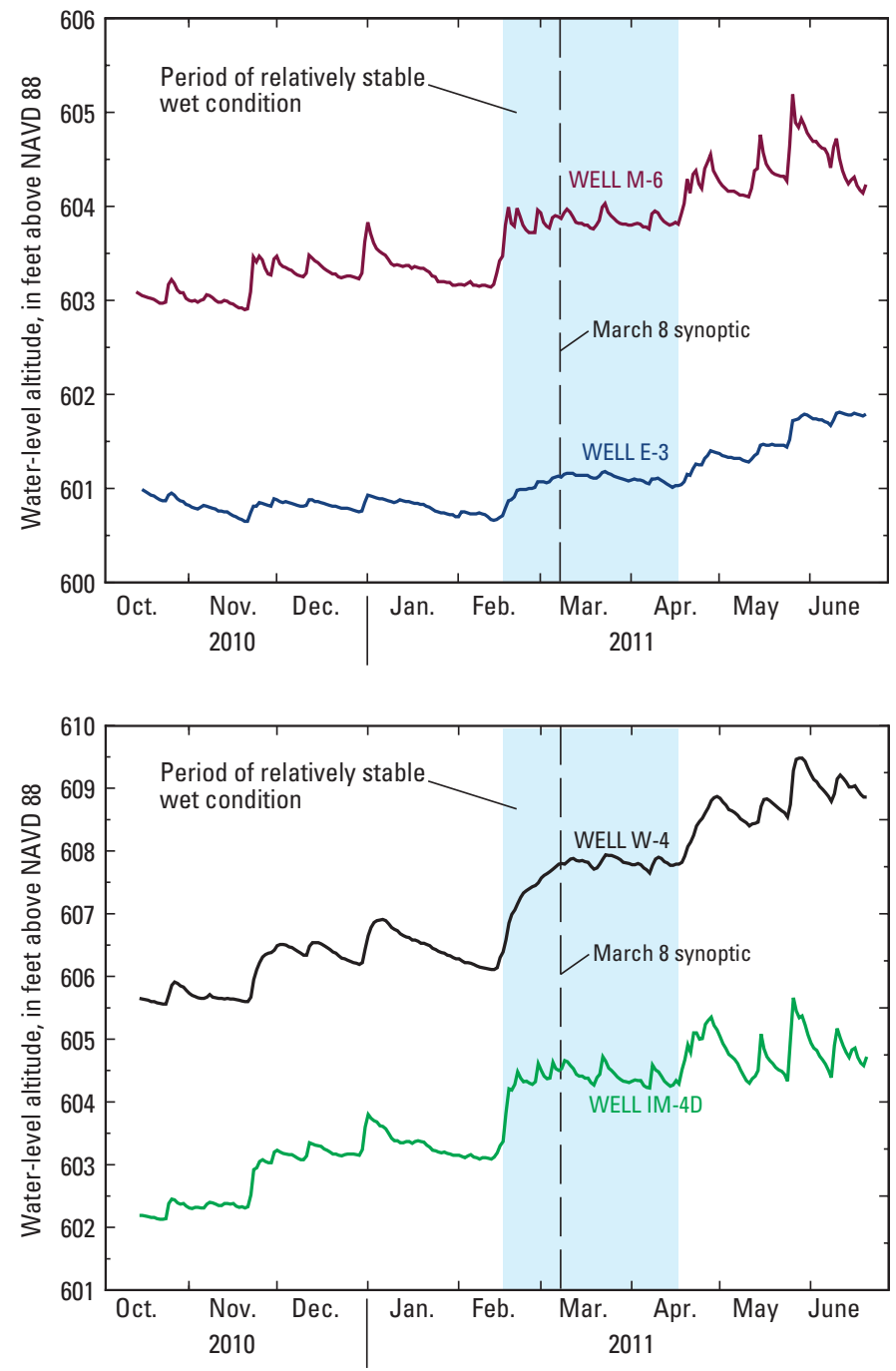

Figure 14. Continuous water-level altitude in six wells, October 2010-June 2011, near Long Lake at Indiana Dunes National Lakeshore. 


\section{Groundwater/Surface-Water Interaction}

Isiorho and others (1996) describe East Long Lake as an area of groundwater recharge to the surficial aquifer, whereas Shedlock and others (1994) describe East Long Lake as a "flow-through" lake, meaning water leaves the groundwater system and discharges into the lake at one point, then reenters the groundwater system through seepage at another. Differences between the water levels measured during the dry weather (October 2002) and wet weather (March 2011) periods indicate that East Long Lake functioned as an area of groundwater recharge during October 2002 and a "flowthrough" lake during March 2011, when the groundwater divide was south of US-12. These differences most likely relate to the discontinued use of the filtration pond, which is believed to have acted as an important source of recharge to East Long Lake when it was actively being used. Wetlands to the south of West Long lake act as points of recharge to the surficial aquifer in both dry weather (October 2002) and wet weather (March 2011).

\section{Surface-Water Flow}

Discharges from US-12 ditch were measured on October 16, 2002, and March 8, 2010, by means of a V-notch weir at the western terminus of the ditch (CS-1, fig. 3), in accordance with procedures described by Holmes and others (2001) (table 6). Calculated groundwater inflow based on discharge measurements made on the US-12 ditch in October 2002 (dry weather) was $0.257 \mathrm{ft}^{3} / \mathrm{s}$; in March 2011 (wet weather), groundwater inflow based on discharge measurements was calculated to be $0.878 \mathrm{ft}^{3} / \mathrm{s}$. Streamflow in the US-12 ditch at site CS-1 enters the GSD sewer system and leaves the Long Lake watershed. These instantaneous discharge values, when converted to a daily volume, suggest that flow from the US-12 ditch into the GSD sewer system accounted for about 166,100 gal/d during the dry weather of October 2002 and about 567,500 gal/d during the wet weather of March 2011.

Table 6. Discharge measurements on streams and ditches in the study area.

$\left[\mathrm{ft}^{3} / \mathrm{s}\right.$, cubic feet per second; - , not applicable]

\begin{tabular}{|c|c|c|c|c|c|}
\hline $\begin{array}{c}\text { USGS station-identification } \\
\text { number }\end{array}$ & Site name & Water body & Date & $\begin{array}{c}\text { Measured } \\
\text { discharge } \\
\left(f^{3} / s\right)\end{array}$ & $\begin{array}{l}\text { Measurement error } \\
\text { (percent) }\end{array}$ \\
\hline \multicolumn{6}{|c|}{ Dry weather } \\
\hline 413606087151901 & CS-1 & US-12 ditch & $10 / 16 / 2002$ & 0.257 & - \\
\hline 413428087172201 & B-CENT & Little Calumet River & $10 / 16 / 2002$ & 22.7 & 5 \\
\hline 413529087133301 & B-90 & Little Calumet River & $10 / 16 / 2002$ & 36.4 & 8 \\
\hline 04095090 & 04095090 & Portage-Burns Waterway & $10 / 16 / 2002$ & 322 & 12 \\
\hline 413645087102501 & B-249 & East Arm Little Calumet River & $10 / 16 / 2002$ & 240 & 8 \\
\hline 413535087124501 & WC-1 & Willow Creek & $10 / 16 / 2002$ & 1.6 & 10 \\
\hline - & PWTP & - & $10 / 16 / 2002$ & 4.7 & - \\
\hline \multicolumn{6}{|c|}{ Wet weather } \\
\hline 413606087151901 & CS-1 & US-12 ditch & 03/08/2011 & 0.878 & - \\
\hline- & - & County Line Road ditch & 03/17/2011 & 0.15 & 8 \\
\hline 413437087164301 & B-CLAY & Little Calumet River & $12 / 03 / 2010$ & 133 & 8 \\
\hline 413538087131301 & B-20 & Little Calumet River & $12 / 03 / 2010$ & 137 & 5 \\
\hline
\end{tabular}


Results of discharge measurements made October 16, 2002, on the Little Calumet River indicate groundwater inflows to several reaches of the ditch during the dry weather of October 2002 (fig. 3). Streamflow was measured where the Little Calumet River is crossed by Central Avenue (B-CENT) and Interstate 90 (B-90) and at a USGS streamgage north of US-12 (USGS 04095090). Discharge was also measured on East Arm Little Calumet River where it is crossed by Indiana route 249 (B-249) and on Willow Creek approximately $1,000 \mathrm{ft}$ downstream of US-20 (WC-1). Discharge from the Portage Wastewater Treatment Plant (PWTP) into the Little Calumet River was also compiled from reported records (Ricki Dodd, Plant Manager, Portage Wastewater Treatment Plant, written commun., 2002).

Groundwater seepage to the Little Calumet River was calculated from the discharge measurements. Because B-CENT is outside of the study area, estimated groundwater seepage to the Little Calumet River was evenly distributed between B-CENT and B-90 by calculating the difference between the discharge measurements and dividing by the length of the stream channel between the measurement sites. This allowed for a calculation of an estimated groundwater seepage of $11.4 \mathrm{ft}^{3} / \mathrm{s}$ along the Little Calumet River between Clay Street (B-Clay) and Interstate 90. Between Interstate 90 and the USGS streamgage, groundwater seepage to the Little Calumet River was estimated by subtracting the measured discharge from B-90, WC-1, B-249, and PWTP from the discharge measured at USGS 04095090, and the Little Calumet River is estimated to have gained $39.3 \mathrm{ft}^{3} / \mathrm{s}$ from groundwater seepage. The groundwater seepage between B-90 and the USGS streamgage divided by the length of stream channel was used to estimate the groundwater seepage between the USGS streamgage and Lake Michigan, and the stream is estimated to have gained $7.5 \mathrm{ft}^{3} / \mathrm{s}$ from groundwater seepage.

Estimates of groundwater seepage between Interstate 90 and Lake Michigan are complicated by the fact that flows in the Little Calumet River and the Portage-Burns Waterway are historically highly variable and sometimes reverse direction in response to the water level in Lake Michigan and inflow from East Arm Little Calumet River (fig. 15). Similar conditions were documented by Crawford and Wangsness (1987) in parts of the East and West Branch Grand Calumet River near the Indiana Harbor Ship Canal approximately $12 \mathrm{mi}$ west of the study area. Daily mean discharge calculated for the USGS streamgage on the Portage-Burns Waterway on October 16, 2002, was $303 \mathrm{ft}^{3} / \mathrm{s}$ (U.S. Geological Survey, 2011).

Discharge measurements were made on the Little Calumet River on December 3, 2010, during wetter weather to estimate the amount of groundwater entering the stream from the surficial aquifer (fig. 3). Streamflow was measured where the Little Calumet River is crossed by Clay Street (B-CLAY) and US-20 (B-20). Between Clay Street and US-20, the stream is estimated to have gained $2.0 \mathrm{ft}^{3} / \mathrm{s}$ from groundwater seepage. Daily mean discharge calculated for the USGS streamgage on the Portage-Burns Waterway on December 3, 2010, was $495 \mathrm{ft}^{3} / \mathrm{s}$ (U.S. Geological Survey, 2011). Because the daily mean discharge calculated for the same streamgage on March 8,2011 - the same day as the synoptic water-level measurements $\left(506 \mathrm{ft}^{3} / \mathrm{s}\right)$ - is similar to the discharge the day the other discharge measurements were made, it is believed that the hydrologic conditions resemble each other.

Visual inspections of the areas south of US-12 along County Line Road during winter 2010 and spring 2011 revealed a partially inundated land surface. In March 2011, the County Line Road ditch held relatively stagnant water near the intersection of these two roads, but flowing water was observed at sites about $0.4 \mathrm{mi}$ to the south; water in the ditch flowed south from that point toward where it discharged into the Little Calumet River. A detailed examination of the water levels and bottom of the County Line Road ditch reveals a point near surface-water-level measurement site C-7 (fig. 3), the approximate southern side of the groundwater divide, where water ponds upstream because of accumulated vegetation and debris or the possible collapse of the culvert over the ditch (fig. 16). During data collection in March 2011, flow in the ditch was relatively stagnant upstream of site C-7, and the surface-water-level gradient was relatively flat upstream from that point north to US-12. The surface-water gradient in the County Line Road ditch south of site C-7 slopes much more steeply to the south along the direction of surface-water flow toward the Little Calumet River. Discharge measurements made on the County Line Road ditch on March 17, 2011, approximately 1 week after the synoptic surface-water and groundwater measurements, indicated a streamflow gain from groundwater discharge of about $0.1 \mathrm{ft}^{3} / \mathrm{s}$. The gain was measured about $150 \mathrm{ft}$ downstream of site C-10.

\section{Hydrologic Modeling Parameters from Previous Studies}

Results from several hydrologic investigations in or near the Long Lake watershed and the Indiana Dunes National Lakeshore yielded information about local hydrogeology, groundwater, surface-water levels, and flows that affected the design of this study (table 7). These studies relate to the Long Lake study area because of similarities in hydrogeologic setting and climatic conditions. Some characteristics of the Long Lake groundwater model developed for this study are based on conceptual elements and hydrologic properties determined or derived by these previous investigations.

Marie (1976) examined a 3.36- $\mathrm{mi}^{2}$ area about 4 mi east of the Long Lake watershed that was considered for dewatering as part of the construction of a power generation facility. Numerical simulations of that groundwater flow system indicated that an extensive cone of depression would be created by sustained pumping and that interdunal ponds about $0.15 \mathrm{mi}$ away on INDU property could become dry.

Meyer and Tucci (1979) examined the effects of seepage to the surficial aquifer from fly-ash settling ponds and construction-related dewatering on groundwater levels in the Cowles Unit at the Indiana Dunes National Lakeshore, 


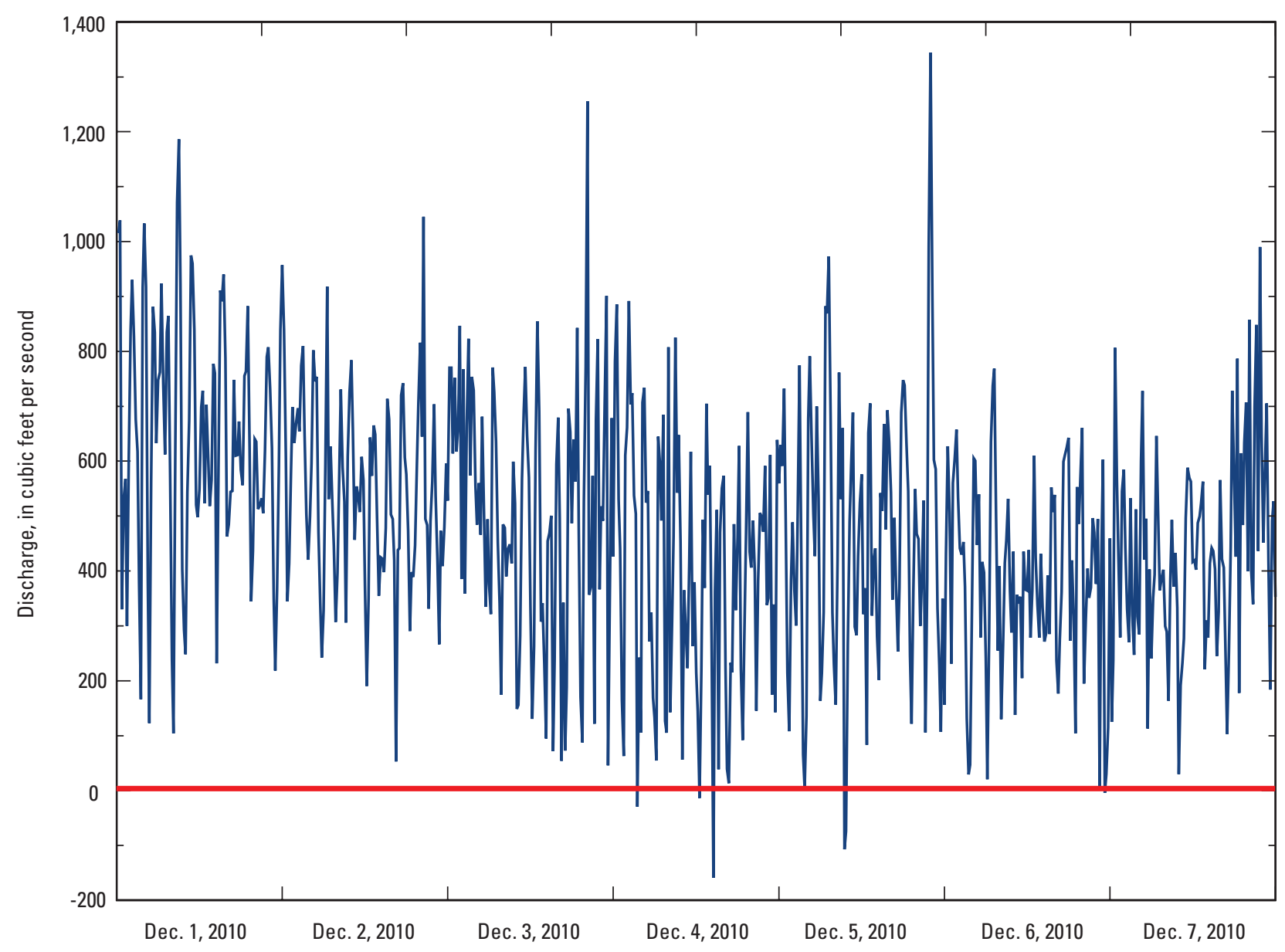

Discharge values falling below red line illustrate periods of time where flow in the Portage-Burns Waterway reverses direction.

Figure 15. Data for December 1-8, 2010, from streamgage USGS 04095090 on the Portage-Burns Waterway at Portage, Indiana.

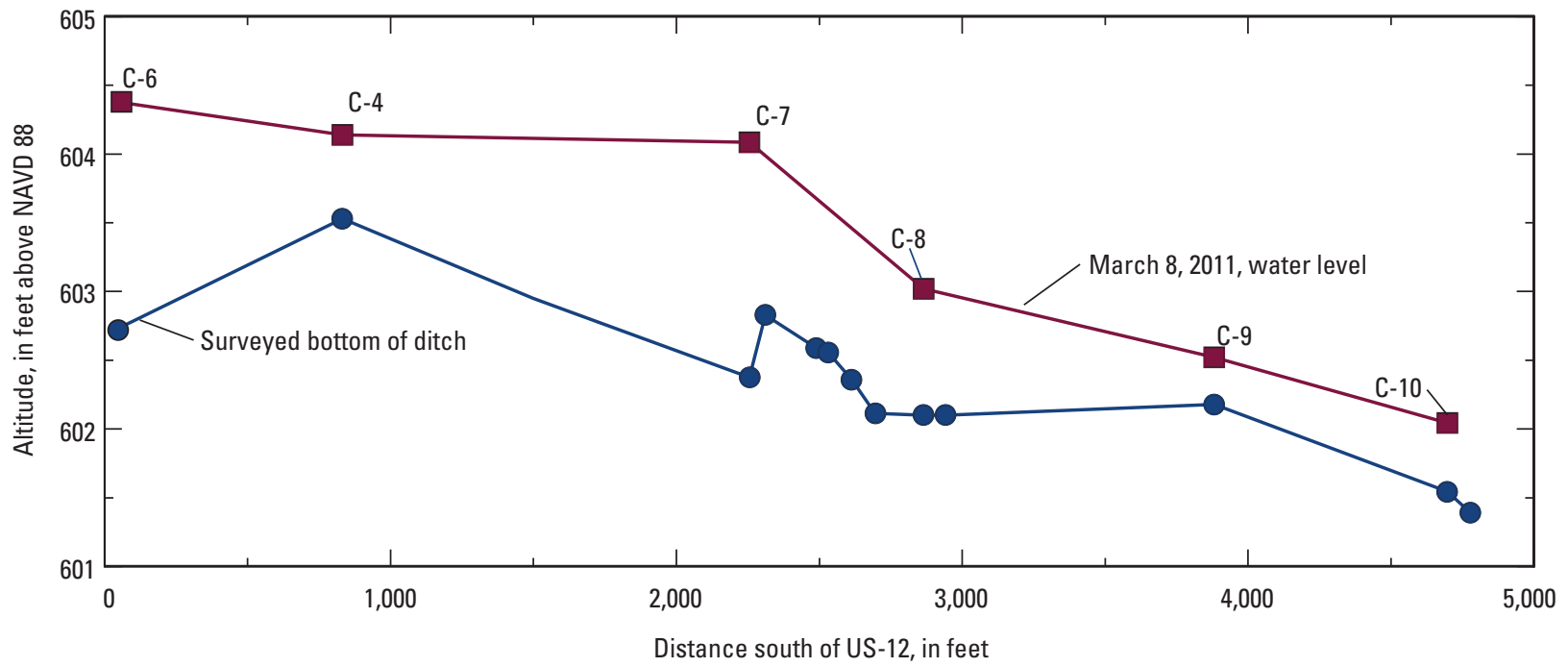

Figure 16. Surface-water gradient (measured March 8, 2011) and surveyed streambed elevations of the ditch along County Line Road, near Indiana Dunes National Lakeshore, Indiana. 


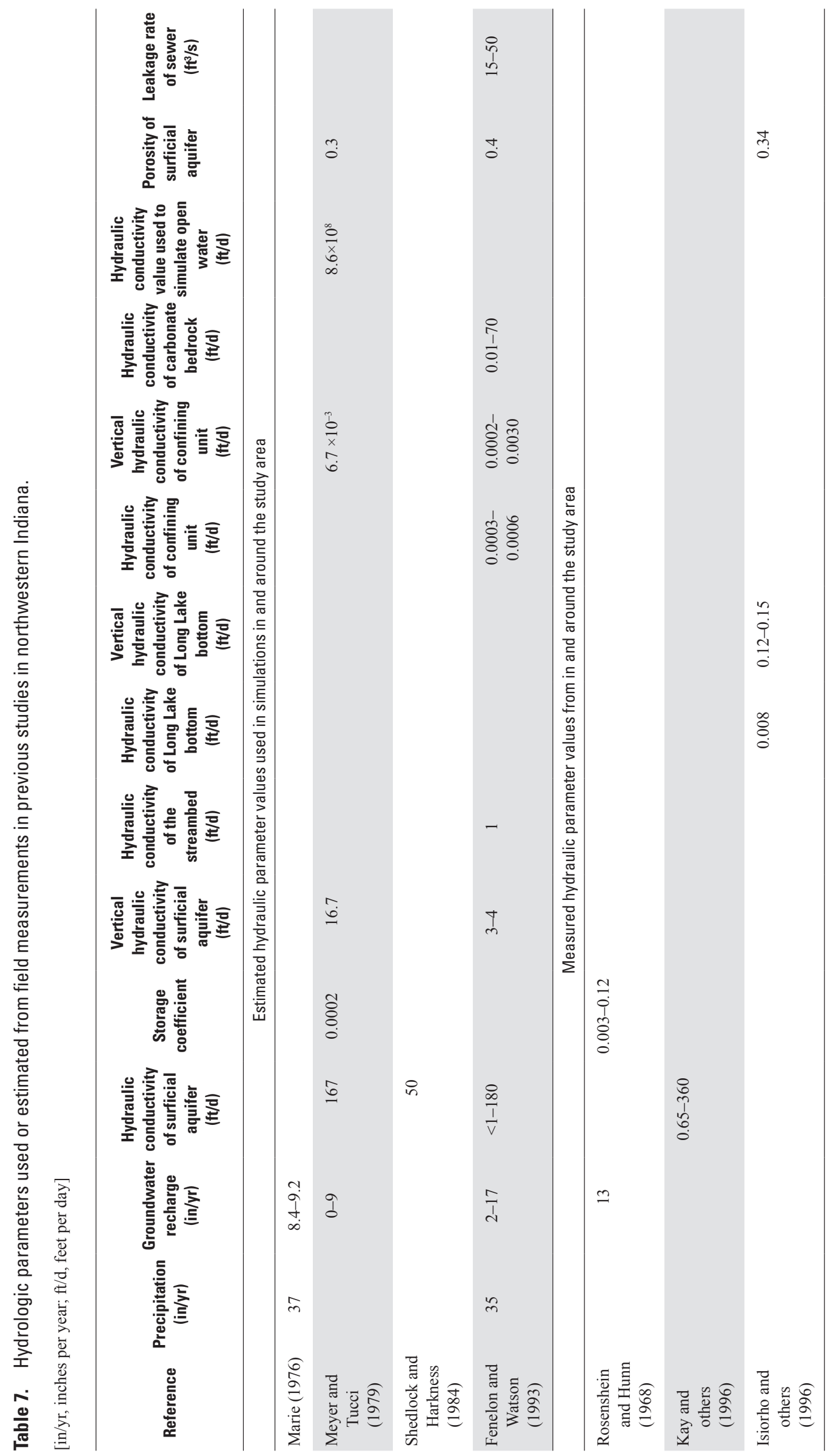


approximately 6 mi east of Long Lake. The study area was similar to that described in Marie (1976). Results of numerical simulations of steady-state conditions characteristic of those in October 1976 indicated that observed groundwater-level rises in the park (as much as $10 \mathrm{ft}$ ) were likely a result of water seeping from nearby fly-ash settling ponds; seepage of as much as 2 million gallons per day was estimated by the simulation. The same groundwater flow model was used to explore the hydrology at a proposed construction site. The construction site was surrounded by a slurry wall and was being dewatered to facilitate construction. Results of the simulations indicated that water levels were being lowered at INDU, outside of the slurry containment, by groundwater seepage through or under the wall. Notably, field data indicated that groundwater flow was generally in the vertical direction from below. Gillies and Lapham (1980) reconfigured the numerical model by Meyer and Tucci (1979) in response to updated data and a new configuration of simulated water withdrawals from the aquifer. The water levels simulated by Gillies and Lapham (1980) did not substantially differ from those documented in Meyer and Tucci (1979).

Shedlock and Harkness (1984) used numerical simulations to examine the potential obstruction of surface-water flow in Brown ditch in eastern parts of INDU and to compute the effects of ditch dredging on the water table. The study was prompted by groundwater flooding in basements in a nearby residential area during springtime and a desire to generally lower the water table. Simulated water-table declines in response to simulated ditch dredging ranged from 0.2 to $2.0 \mathrm{ft}$ depending on the ditch configuration.

Kay and others (1996) used slug-test results from wells completed in the surficial sand aquifer to describe the hydrogeology and determine the horizontal hydraulic conductivity of the surficial aquifer near the Grand Calumet River and the Indiana Harbor Canal, approximately $8 \mathrm{mi}$ west of the Long Lake watershed. Hydraulic conductivities ranged from 0.65 to $360 \mathrm{ft} / \mathrm{d}$, with most values between 2.1 and $30 \mathrm{ft} / \mathrm{d}$. These slugtest-derived values were also in fair agreement with hydraulic conductivities estimated from nearby specific-capacity tests, which ranged from 8.0 to $130 \mathrm{ft} / \mathrm{d}$ and had a mean value of $60 \mathrm{ft} / \mathrm{d}$. The mean hydraulic conductivity computed from specific-capacity-test data is about double the values calculated from the slug-test data. Differences in the values can relate to differences in the method of analysis, the volume of aquifer tested, and the location of testing.

Fenelon and Watson (1993) examined the hydrology near the Grand Calumet River and the Indiana Harbor Canal, approximately $8 \mathrm{mi}$ west of the area examined in this investigation, using measured field data and numerical simulations. A contour map of water-level altitudes indicated a groundwater divide that paralleled the shoreline and separated groundwater flowing south to the Grand Calumet River from that flowing north to Lake Michigan. Results of the numerical simulations indicated that groundwater discharged about $15 \mathrm{ft}^{3} / \mathrm{s}$ to leaky sewers, $10 \mathrm{ft}^{3} / \mathrm{s}$ to the Grand Calumet River, $4 \mathrm{ft}^{3} / \mathrm{s}$ to Lake Michigan, and 0 to $10 \mathrm{ft}^{3} / \mathrm{s}$ to the underlying bedrock. Groundwater leakage into the sewers varied from 15 to $50 \mathrm{ft}^{3} / \mathrm{s}$, but these estimates were based on generalized locations of sewer lines and their elevations relative to the water table. Fenelon and Watson (1993) stated,

The recharge rate of the Calumet aquifer is virtually unknown; values of 4 to $23 \mathrm{in} / \mathrm{yr}$ were used by investigators in several modeling studies of the aquifer. Estimating recharge rates in a given area is complicated by urban and industrial development, which increases surface-water runoff and lowers recharge rates.

Precipitation and recharge rates mentioned in Fenelon and Watson (1993) include a precipitation rate of $35 \mathrm{in} / \mathrm{yr}$ (National Oceanic and Atmospheric Administration, 1987) and recharge rates of $13 \mathrm{in} / \mathrm{yr}$ (Rosenshein and Hunn, 1968) and 4-23 in/yr (Meyer and Tucci, 1979; Warzyn Engineering, Inc. 1987; Watson and others, 1989). In Fenelon and Watson (1993), the recharge was varied between 2 and $17 \mathrm{in} / \mathrm{yr}$. Shedlock and others (1994) indicated that the bedrock in the eastern part of their study area probably discharges some water up through the clay unit.

Greeman (1995) examined surface-water and groundwater levels at 96 sites measured in Lake County between August 1985 and September 1992; part of that study area approximately coincides with the western boundary of the Long Lake study area in this report. Groundwater levels were annually highest in June and July and lowest in September and October; a short-duration peak was usually observed in February or March and was related to the spring snowmelt. Daily effects of evapotranspiration were clearly observed, affecting daily groundwater levels during the growing season by more than $0.2 \mathrm{ft}$. A major drought (1988) did not substantially lower groundwater levels but did reverse vertical gradients in some paired wells. Wells near streams responded quickly to increasing streamflow and rising surface-water levels.

Isiorho and others (1996) used seepage meters and minipiezometers to measure seepage rate and direction in bed sediments of Long Lake. Results of that study indicated that water was seeping from Long Lake into the surficial aquifer. The volume seeping out of Long Lake was about 22 percent of the annual lake recharge and was a relatively large amount $\left(8.8 \times 10^{6} \mathrm{ft}^{3} / \mathrm{yr}\right)$ compared to the annual recharge to the drainage basin $\left(1.7 \times 10^{7} \mathrm{ft}^{3} / \mathrm{yr}\right)$. The horizontal hydraulic conductivity of the Long Lake lakebed material was estimated by slug tests as $0.0079 \mathrm{ft} / \mathrm{d}$, and the vertical hydraulic conductivity of the lakebed was 0.12 to $0.15 \mathrm{ft} / \mathrm{d}$. 


\section{Simulation of Groundwater Flow and Availability}

A groundwater model was used to simulate the groundwater flow system in the vicinity of Long Lake, Indiana Dunes National Lakeshore. The groundwater model will establish a better understanding of the effects proposed drainage modifications can have on the hydrologic system in the area and will help the GSD, the NPS, and other local stakeholders manage and protect the resources within the study area. A specific objective in developing the model was to understand the interaction of water levels in East and West Long Lake, the US-12 ditch, and the County Line Road ditch with groundwater levels in nearby areas. This section describes

- the conceptual model of the hydrogeology used to guide model construction and the simplifying assumptions made,

- discretization of the groundwater flow system, boundary conditions, stresses, and hydraulic properties,

- calibration of the model to measured conditions,

- the sensitivity of model results to model input,

- the presentation of model results in the form of simulated water-table contours and flow paths,

- the results of scenarios that illustrate the effects of different engineering controls and climatic conditions on the hydrology near Long Lake, and

- the limitations and qualifications associated with the results.

The groundwater flow system was modeled by using the MODFLOW-NWT computer code for simulating groundwater flow of uniform density (Niswonger and others, 2011).

MODFLOW-NWT was used because of numerical stability problems (primarily with wetting and drying of model cells) with initial model runs with MODFLOW-2000 (Harbaugh and others, 2000). MODFLOW-NWT is a stand-alone program intended to solve computational problems involving nonlinear parts of the unconfined groundwater flow equation used in the model and to enable cells in simulated unconfined parts of the model to dry and rewet as the computer calculations converge to a solution (Niswonger and others, 2011). After the conversion to MODFLOW-NWT, the stability problems did not occur.

\section{Simplifying Assumptions of the Conceptual Model}

Several simplifying assumptions were used to develop the groundwater model. The following assumptions were made to represent the geometry, hydraulic properties, and other characteristics of the groundwater flow system under the study area:

1. The geologic deposits of the surficial aquifer are generalized as an unconfined sand aquifer.

2. Horizontal and vertical hydraulic conductivity within the surficial aquifer are assumed to be uniform throughout the model except in southern and eastern parts of the study area, where a lower zone of the surficial aquifer with lower horizontal and vertical hydraulic conductivity is represented.

3. The surficial aquifer in the model is underlain by a silt and clay confining unit. The surficial aquifer is assumed to be considerably more permeable than the underlying confining unit. Flow rates are determined by the thickness and vertical hydraulic conductivity of the silt and clay unit and by the water-level difference between the surficial sand aquifer and the bedrock.

4. The thickness of all simulated streambeds is assumed to be $1 \mathrm{ft}$. The calibrated value of vertical hydraulic conductivity of the streambed is based on this 1-ft streambed thickness.

5. The groundwater flow system is assumed to be in dynamic equilibrium. Dynamic equilibrium is defined as a water-level fluctuation above and below a longterm mean water level. The starting water levels are assumed to be at steady-state and not in any longterm rise or fall.

\section{Spatial Discretization}

The digital model is based on a rectangular blockcentered finite-difference grid network that extends $6.5 \mathrm{mi}$ in length and $3.5 \mathrm{mi}$ in width (fig. 17). The active grid generally extends to natural boundaries: Lake Michigan on the north and the Little Calumet River on the south and the PortageBurns Waterway to the east. Areas outside of these boundaries are represented by inactive cells and are not simulated by the groundwater model. The western model boundary is defined approximately along a flow line and sufficiently to the west so as to not affect simulated flow patterns near Long Lake. The model grid contains 114 rows and 409 columns for a total of 46,626 cells, ranging in size from 50 by $50 \mathrm{ft}$ at the center of the model to 500 by $500 \mathrm{ft}$ at the corners of the model. A cell size of $50 \mathrm{ft}$ by $50 \mathrm{ft}$ was the most common in the model grid and provides sufficient water-level and flow detail within the area of Long Lake and the US-12 ditch.

Groundwater flow is simulated by three model layers that represent Long Lake and the surficial aquifer (fig. 18). Layer 1 represents open-water areas of the model that include East and West Long Lake, as well as a filtration backwash pond 


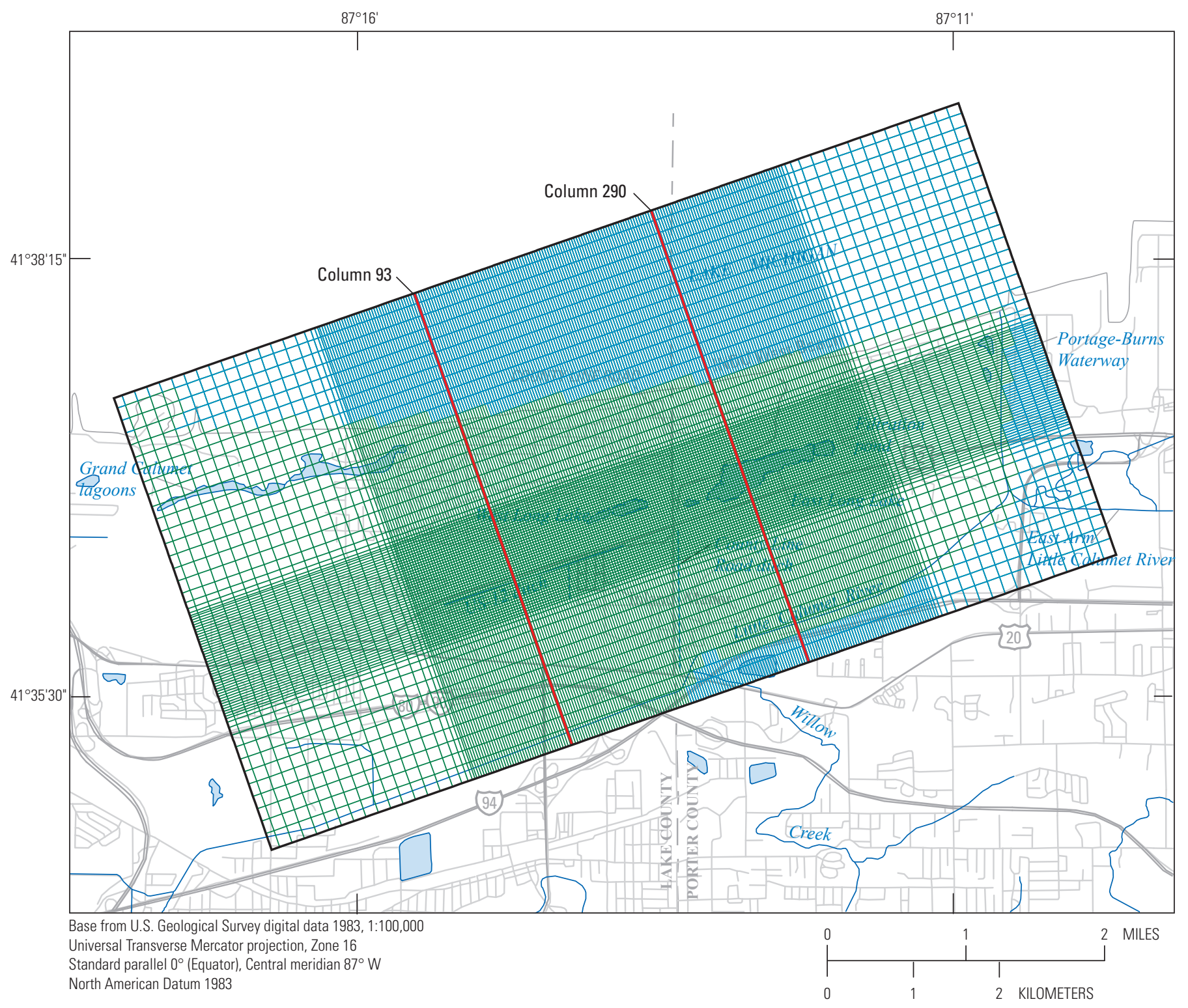

\section{EXPLANATION}

Active grid cells within the model boundary

Inactive grid cells within the model boundary

Figure 17. Model grid used in the simulation of groundwater flow in the vicinity of Long Lake, near Gary, Indiana. 


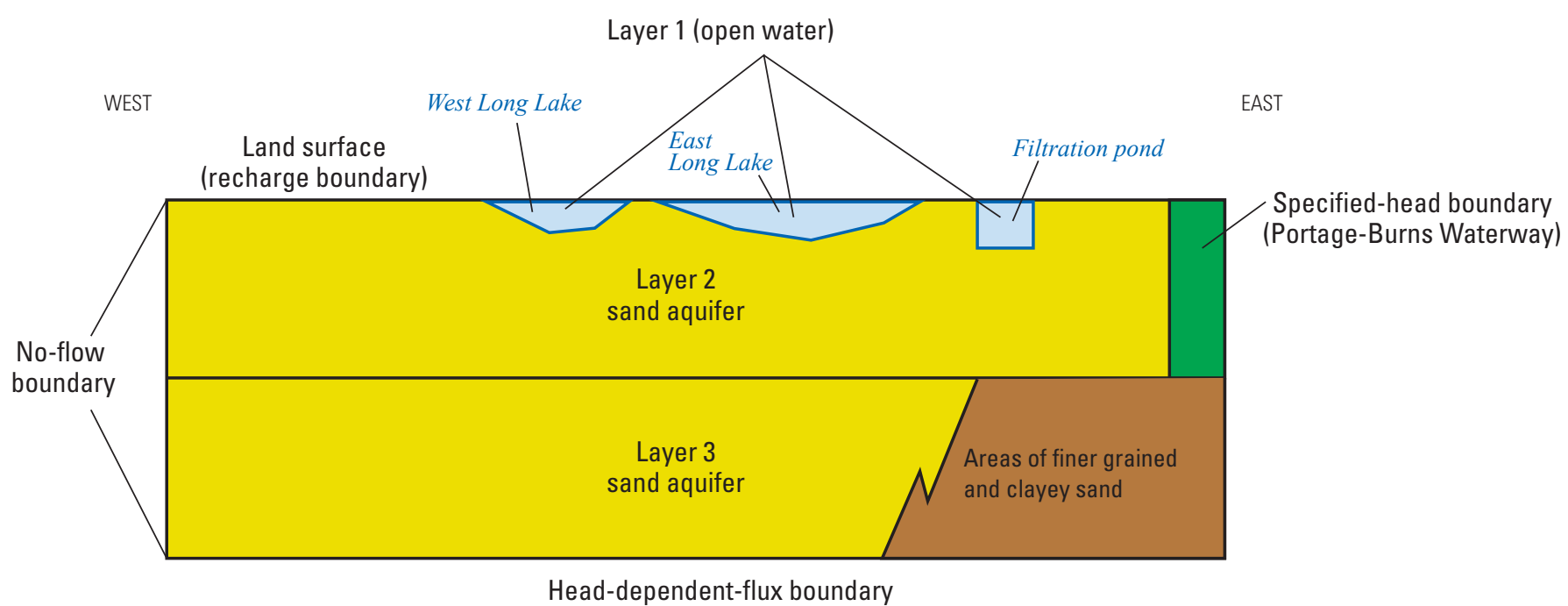

Figure 18. Layering design for the model in the vicinity of Long Lake, near Gary, Indiana.

at the far east side of East Long Lake. Layer 1 is allowed to be wet in response to the simulated conditions of the model. All active areas of layer 1 have the same hydraulic properties of the open-water areas of East and West Long Lake. Layers 2 and 3 represent the surficial aquifer. The surficial aquifer is divided into two layers to represent potential vertical flow. Layers 1 and 2 were simulated as potentially confined or unconfined, and layer 3 was everywhere confined. The bottom of layer 3 represents the top of a till and glacial-lacustrine clay and silt confining unit found throughout the study area (Shedlock and others, 1994).
The bottom of layer 1 represents the land surface of the modeled area. Three data sources were used to compile the land-surface layer within the model (fig. 19). Land-surface data from a digital elevation model with a resolution of $98.4 \mathrm{ft}$ (30 m) (Brown and others, 2004) was supplemented with bathymetric data collected in February 2004 in areas of East Long Lake and West where water depth was greater than $1 \mathrm{ft}$ (Lee R. Watson, U.S. Geological Survey, written commun., 2003), and a 9.84-ft (3-m) digital elevation model available only in the immediate vicinity of Long Lake (David Bucaro, U.S. Army Corps of Engineers, written commun., 2005). 


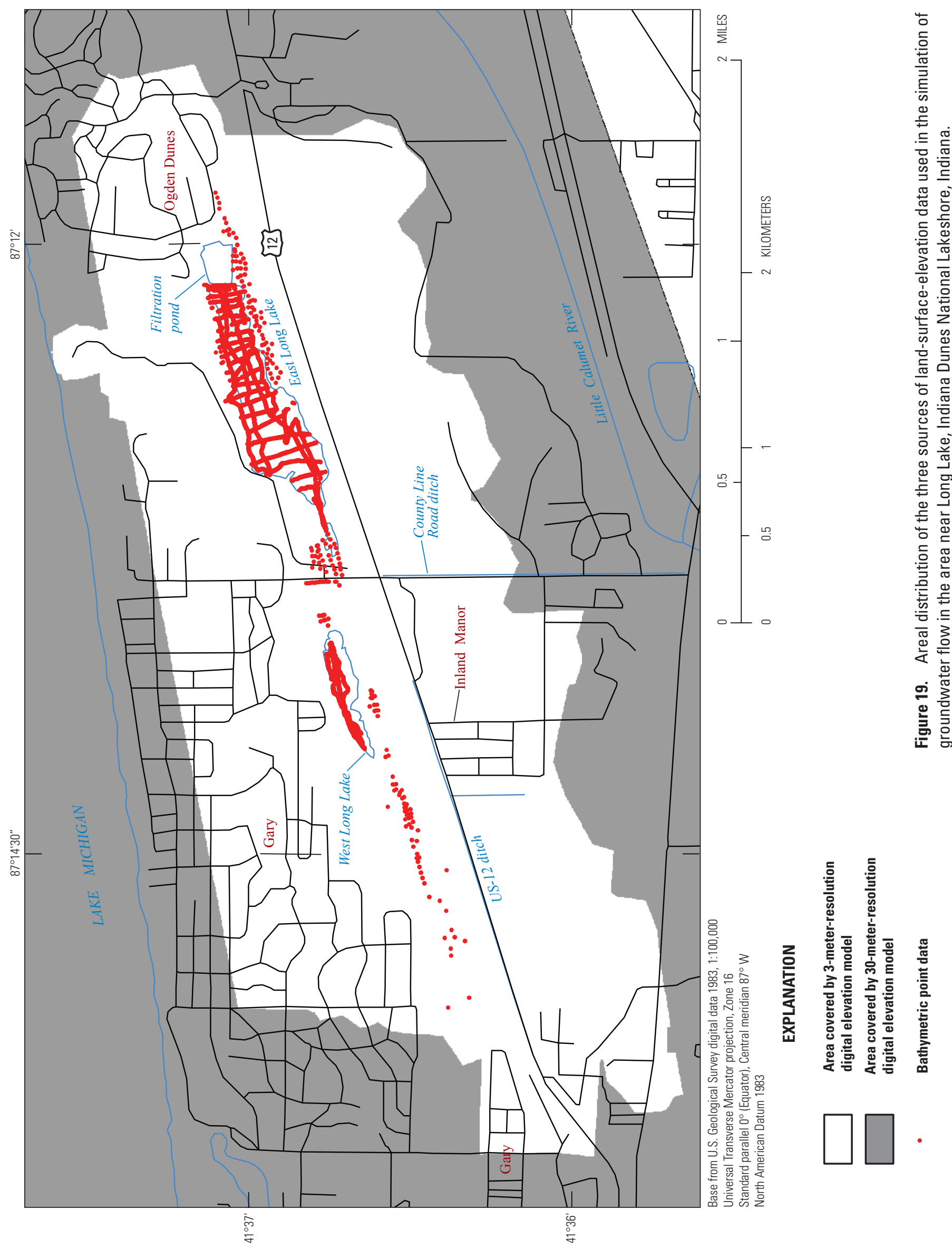




\section{Boundary Conditions}

River and drain cells (McDonald and Harbaugh, 1988) were used in layer 2 to represent the streams shown in figure 20. A total of 501 river cells were used to simulate the Little Calumet River and the Portage-Burns Waterway. River cells represent large streams that can supply appreciable water to the groundwater flow system if the water table declines below the bottom of the stream. A total of 175 drain cells were used to simulate the US-12 ditch (fig. 20). A total of 71 drain cells were used to simulate the County Line Road ditch. A total of 13 drain cells were used to simulate an unnamed ditch that drains to the Little Calumet River in the southwest part of the modeled area. Drain cells receive groundwater discharge but do not recharge the groundwater system whenever the water table falls below the bottom of the drain. A streambed hydraulic conductivity of $30 \mathrm{ft} / \mathrm{d}$ for the Little Calumet River was initially chosen on the basis of the physical observation that the streambed was composed mostly of clean sand. A smaller streambed hydraulic conductivity of $0.5 \mathrm{ft} / \mathrm{d}$ was initially chosen for the ditches along US-12 and County Line Road and the unnamed ditch that drains to the Little Calumet River because both streambeds were observed to contain sand, peat, muck, and organic material. Bottom elevations for all of the stream and drain cells were based on field observations made at data collection sites along the channel (fig. 3) and interpolated between.

Boundary conditions in the groundwater model were selected so that the type and location of the boundary would have minimal effect on simulated flow in the modeled area. A constant-flux boundary was used at the top of the model to represent recharge as a spatially variable, fixed value for each cell. A head-dependent-flux boundary was used at the bottom of the model to simulate exchange of vertical flow through the silt and clay confining unit separating the surficial aquifer from the confined basal sand and bedrock aquifer. As inferred from available water levels from the Water Well Record Database maintained by the Indiana Department of Natural Resources, Division of Water, the flow direction is downward from the surficial aquifer into units below the on the west side of the model and upward on the east (Indiana Department of Natural Resources, 2002). Flow rates are determined by the thickness and vertical hydraulic conductivity of the silt and clay unit and by the water-level difference between the surficial sand aquifer and the confined sand and bedrock. A no-flow boundary condition was used on the west side of the model where groundwater flow is assumed to be parallel to the boundary, as shown in Kay and others (1996, pl. 1).
Because of its size, the Little Calumet River is assumed to be a hydrologic boundary to the flow system of the model. A specified-head boundary (consisting of river cells) was placed along the southern and eastern boundaries of the model along the Little Calumet River (fig. 20). The head values were based on the elevation of the water surface measured in the stream. A constant-head boundary was placed along the northern edge of the model to represent Lake Michigan and the Grand Calumet lagoons (fig. 20).

Initial water levels for all model layers were set at an altitude of $595 \mathrm{ft}$, which ensured that all model cells would contain water at the beginning of the simulation. Water levels range generally less than $20 \mathrm{ft}$ throughout the modeled area; therefore, simulated water levels did not need to change substantially to final values during the first simulation. In subsequent model simulations, final water levels calculated by the model were substituted into the starting water levels so that time required for calculations associated with a simulation was minimized.

\section{Hydraulic Properties}

Initial values for the horizontal hydraulic conductivity (referred to as "hydraulic conductivities" in the remainder of the report) were based on previous reported values (table 7) and on other published values for similar materials (Freeze and Cherry, 1979; Fetter, 1994). The one component of the model thought to have a substantial influence on flow is the surficial sand aquifer. Hydraulic conductivity of the surficial aquifer was based on aquifer-test information from previous studies reported by Kay and others (1996, p. 30). According to Kay and others, values of hydraulic conductivity commonly range from 2 to $30 \mathrm{ft} / \mathrm{d}$. The upper-end value $(30 \mathrm{ft} / \mathrm{d}$ ) was chosen as the initial value on the basis of observed aquifer sediment characteristics in the study area. Hydraulic conductivity of open water in layer 1 was set at 7,000 ft/d to represent the low resistance of flow through open water. The value of $7,000 \mathrm{ft} / \mathrm{d}$ was the highest value that did not cause instability during model iterations. Hydraulic conductivity of the berm material surrounding the filtration pond was given the same value as for the surficial sand aquifer because the dikes around the pond were made of local sands. Areas thought to contain localized finer grained deposits and possible locally confined aquifer conditions on the basis of previous studies were simulated with substantially lower horizontal and vertical hydraulic conductivities in layer $3\left(4 \mathrm{ft} / \mathrm{d}\right.$ and $2 \times 10^{-3} \mathrm{ft} / \mathrm{d}$, respectively; fig. 21). 


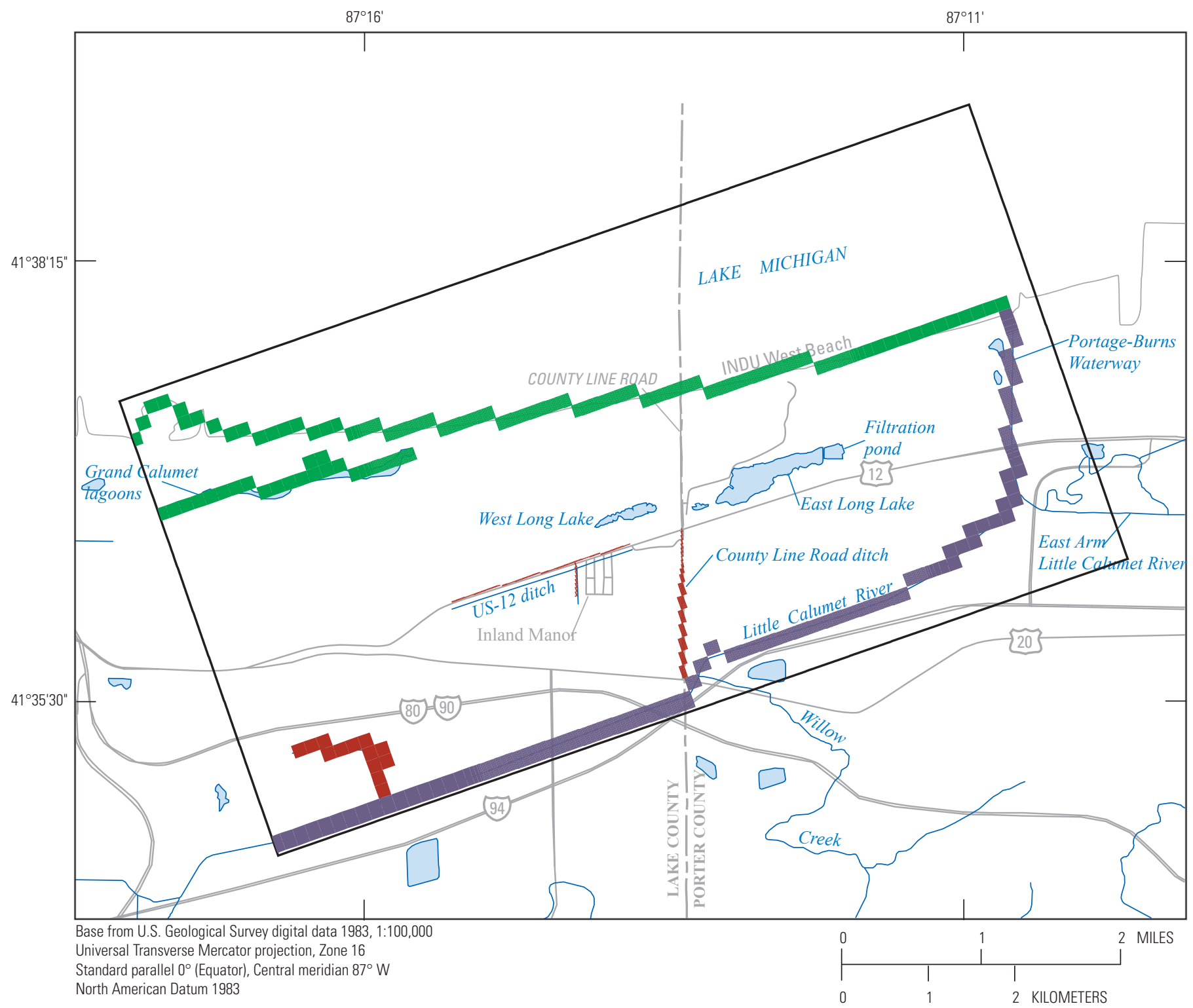

\section{EXPLANATION}

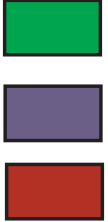

Constant-head cells

River cells

Drain cells

Figure 20. Boundary conditions and types of stream cells used in the simulation of groundwater flow in the study area. 


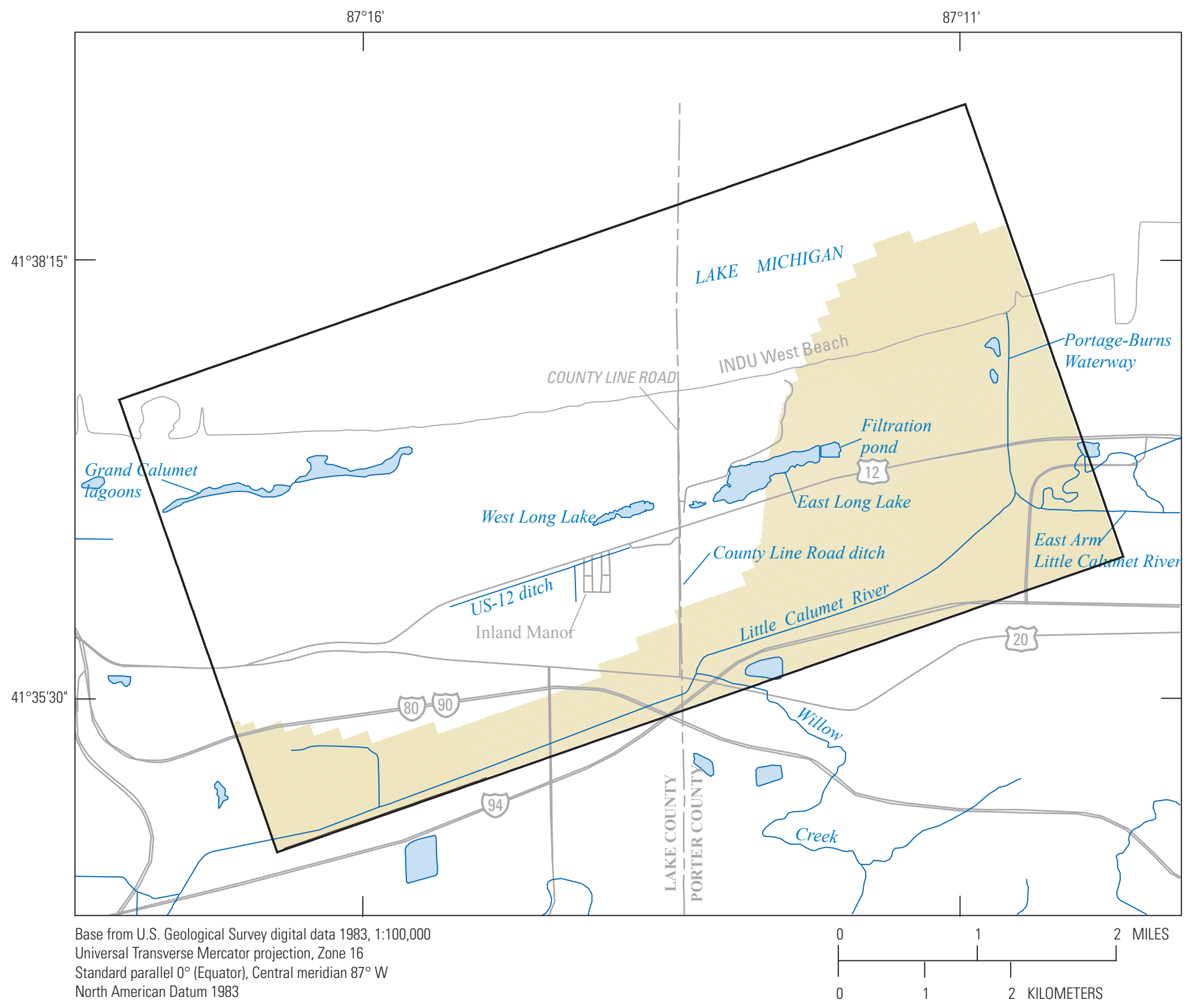

(Equator) Central meridian $87^{\circ} \mathrm{W}$

EXPLANATION

Cells representing the zone of low horizontal and vertical conductivity in layer 3

Figure 21. Location of zone of low horizontal and vertical hydraulic conductivity in layer 3 of the groundwater flow model. 


\section{Recharge}

Initial values of recharge rate were based on previous values used for similar environments in other models, such those of as Meyer and Tucci (1979), Arihood and Cohen (1998), and Duwelius and others (2001). Initial individual recharge rates for four areas were defined as follows: undeveloped, 15 in/yr; urban, 7 in/yr; wetland, 3 in/yr; and deep open water, $1 \mathrm{in} / \mathrm{yr}$ (fig. 22). Undeveloped area includes some areas of low-density development. Recharge was applied to the top of the model.

A recharge value applied to a single model cell in the middle of the filtration pond within layer 1 was used to simulate the infiltration of water to the surficial aquifer from the filtration pond (fig. 22). A value of $3.03 \times 10^{4}$ in/yr was assigned to the cell, which simulates the discharge of approximately $130,000 \mathrm{gal} / \mathrm{d}$ of water to the surficial aquifer.

Water-withdrawal data were not needed to construct the model. Large-scale withdrawals from the aquifer (greater than $100,000 \mathrm{gal} / \mathrm{d}$ ) do not occur in the modeled area, and most homes receive their water from municipal supplies that derive water from Lake Michigan.

\section{Model Calibration}

Calibration is the process of adjusting the model input variables, also called parameters, to produce the best match between simulated and observed hydraulic heads and flows. In this report, the term "head" is used interchangeably with water-level altitude (Lohman and others, 1972). Many of the model parameters were treated as parameters to be automatically adjusted during parameter estimation. During calibration of the dry-weather October 2002 hydrologic condition, parameters were adjusted manually at first and then by use of automatic parameter-estimation techniques to match hydraulic heads from observation wells and streamflow fluxes. ("Streamflow flux" in this case is the change in discharge along a reach attributed to groundwater inflow).

Parameter estimation in MODFLOW-NWT is accomplished with the UCODE_2005 program (Harbaugh, 2005; Poeter and others, 2005), which uses a nonlinear least-squares regression method to aid in estimating parameters that represent hydrologic properties and to further evaluate the model. The parameters estimated during calibration represent the hydrologic properties distributed as constant values over broad areas or parameter zones, as well as over extended linear features such as rivers. Because parameters represent hydraulic conditions over broad areas, calibrated parameter values are not necessarily expected to equal or agree with specific values of field tests within a given zone.

Parameter-estimation techniques were used to estimate values of hydrologic properties for the groundwater flow simulations; some of those values were then adjusted manually to the final parameter values used in the model. This method is explained in great detail in Hill (1998) and Hill and Tiedeman (2007). Nonlinear least-squares regression is an automated parameter-estimation technique that was used to compute final parameter values. The regression method is a more efficient and objective process compared to trial-and-error calibration because all parameter values are adjusted automatically and concurrently to obtain the best possible fit between observed and simulated values. The numerical difference between observed and simulated values is called a residual. During the parameter-estimation process, parameter values are estimated by minimizing the sum of the squared weighted residuals, called the objective function. Parameter estimation was manually constrained by the authors so that parameter values used for the groundwater simulations would be reasonable and plausible. In some cases, parameter estimation resulted in the final reported value; but in others, a slight manual trial-anderror adjustment of the estimated parameter value resulted in new values that achieved lower total root mean square (RMS) error values for both head and flow observations. If manual adjustment of a parameter from the estimated value did not achieve lower RMS error values, the original parameter estimated value was adopted and is reported herein as the final value. The model was considered calibrated once the overall fit of the groundwater flow model was within $1 \mathrm{ft}$ (a further discussion is available in the "Model Fit to Observations" section).

\section{Model Parameters}

In the model, grid cells assumed to have similar hydrologic properties were grouped together as a parameter zone and assigned a single parameter value that was adjusted during the calibration process. In all, 29 different parameters were evaluated for inclusion in the model, and 16 parameters were used in the final model design. Names of the parameters ultimately used in the model and the model component that each parameter represents are listed in table 8 .

The sensitivity of simulated water levels to changes in model parameters was measured to evaluate which parameters could be estimated by means of automated parameter-estimation techniques. The sensitivity of hydraulic heads with respect to various model parameters was calculated by using the sensitivity equation method (Hill and others, 2000). Composite scaled sensitivities (CSS) and significant correlations between parameters were calculated for each parameter (table 8). CSS values aid in determining whether there is adequate information in the calibration data to estimate a particular parameter; generally, parameters that are highly correlated with other estimated parameters cannot themselves be estimated. CSS values less than approximately 0.01 times the largest CSS of the parameters indicate that the regression may not be able to estimate the parameter (Hill, 1998, p. 38; Hill and Tiedeman, 2007, p. 50). 


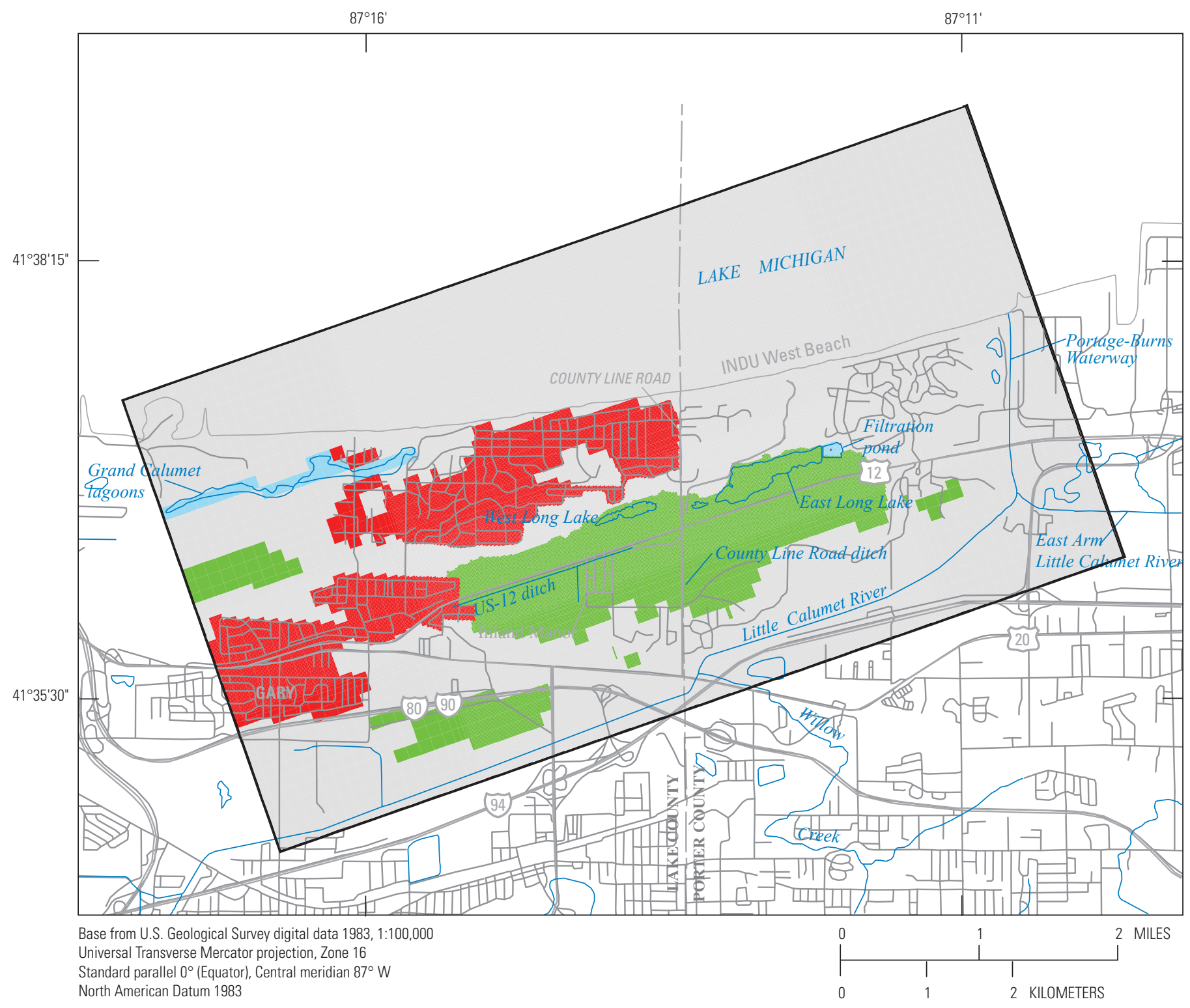

\section{EXPLANATION}

Model cells with recharge values representing undeveloped areas

Model cells with recharge values representing urban areas

Model cells with recharge values representing wetland areas

Model cells with recharge values representing open-water areas

Model cell with recharge values representing seepage from filtration pond (Model cell is in the center of the filtration pond)

Figure 22. Location of recharge zones in undeveloped, urban, wetland, and open-water zones of the groundwater flow model and point representing seepage of water from the filtration pond. 


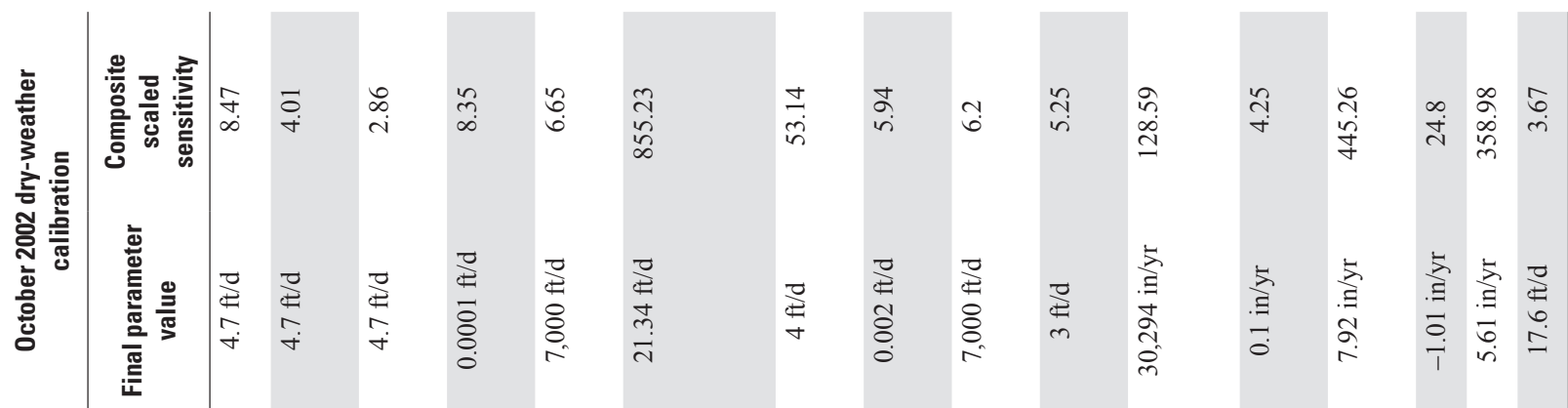

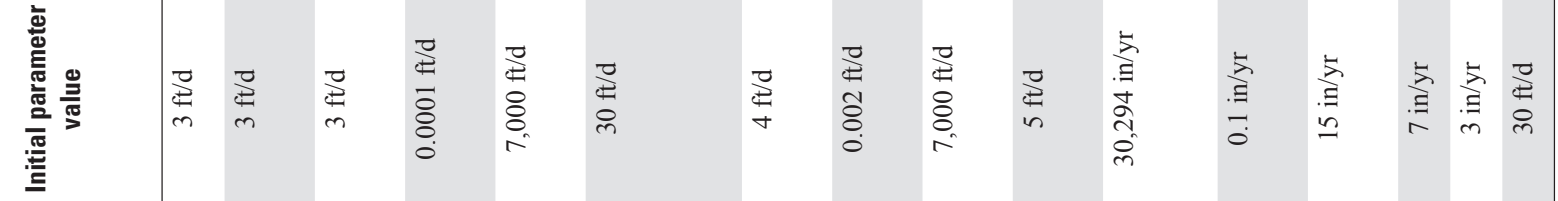

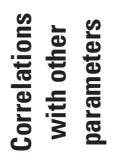




\section{Observations and Observation Weights}

The observations used for model calibration consisted of 29 water-level measurements and 1 streamflow gain/loss measurement made in October 2002 (table 9). Both sets of measurements were made October 16, 2002. Most of the water-level measurements were in the vicinity of East and West Long Lakes and the ditch along US-12. One discharge measurement was made at site CS-1 at the end of the ditch along US-12 before water in the ditch flows into an inlet to the Gary Sanitary District sewer system and was used as a streamflow observation (fig. 3). Owing to the uncertainties of

Table 9. Measured (observed) and model-calculated (simulated) water levels and discharge measurement used as observations and model residuals for the 0ctober 2002 calibrated groundwater model.

\begin{tabular}{|c|c|c|c|c|}
\hline Observation name & Model layer & Observed value & Simulated value & Residual \\
\hline \multicolumn{5}{|c|}{ Water level, in feet above NAVD 88} \\
\hline IM-7 & 2 & 600.96 & 600.937 & $2.26 \mathrm{E}-02$ \\
\hline IM-4S & 2 & 600.34 & 600.952 & -0.611755 \\
\hline IM-4D & 3 & 600.34 & 600.948 & -0.608093 \\
\hline IM-6 & 2 & 599.31 & 600.022 & -0.712158 \\
\hline IM-2 & 2 & 598.88 & 599.235 & -0.354614 \\
\hline M-5 & 2 & 601.79 & 601.173 & 0.617188 \\
\hline E-5 & 2 & 601.62 & 601.912 & -0.291931 \\
\hline M-3 & 2 & 599.96 & 599.654 & 0.306152 \\
\hline E-4 & 2 & 602.1 & 602.366 & -0.265869 \\
\hline $\mathrm{W}-10$ & 2 & 600.75 & 600.55 & 0.200317 \\
\hline E-3 & 2 & 602.12 & 601.748 & 0.371948 \\
\hline W-11 & 2 & 589.9 & 588.631 & 1.26904 \\
\hline M-1 & 2 & 590.29 & 590.728 & -0.437561 \\
\hline E-2 & 2 & 592.57 & 594.025 & -1.45453 \\
\hline W-7B & 2 & 598.76 & 598.841 & $-8.11 \mathrm{E}-02$ \\
\hline W-9 & 2 & 596.03 & 596.085 & $-5.54 \mathrm{E}-02$ \\
\hline 232 & 2 & 583.76 & 584.772 & -1.01208 \\
\hline $\mathrm{W}-7$ & 2 & 598.72 & 598.942 & -0.22168 \\
\hline BH-17 & 2 & 586.99 & 585.338 & 1.65204 \\
\hline $\mathrm{W}-1 \mathrm{~A}$ & 2 & 601.98 & 601.174 & 0.805847 \\
\hline W-5 & 2 & 601.07 & 600.99 & $8.03 \mathrm{E}-02$ \\
\hline $\mathrm{W}-2$ & 2 & 601.48 & 601.545 & $-6.55 \mathrm{E}-02$ \\
\hline W-3DUNE & 2 & 600.02 & 600.786 & -0.766357 \\
\hline $\mathrm{W}-4$ & 2 & 603.07 & 601.828 & 1.24176 \\
\hline M-6 & 2 & 601.03 & 601.535 & -0.505127 \\
\hline LLW-NORTH & 2 & 599.25 & 599.436 & -0.185608 \\
\hline LLE-CENTER & 2 & 602.16 & 601.737 & 0.423218 \\
\hline IM-3S & 2 & 598.95 & 599.205 & -0.2547 \\
\hline IM-3D & 3 & 598.97 & 599.211 & -0.240845 \\
\hline \multicolumn{5}{|c|}{ Discharge, in cubic feet per second } \\
\hline US-12 ditch & (Not applicable) & -0.257 & -0.310 & $5.35 \mathrm{E}-02$ \\
\hline
\end{tabular}


estimating groundwater seepage to the Little Calumet River, the collected data were not used as a streamflow observation in the groundwater model.

Water-level and streamflow gain/loss observations were weighted before they were used in model calibration to reduce the influence of observations that are less accurate and to increase the influence of observations that are more accurate. Residuals of water-level observations are reported in units of feet, and residuals of streamflow are in reported in units of cubic feet per second $\left(\mathrm{ft}^{3} / \mathrm{s}\right)$. The weighting process produces "weighted residuals" (a measure of the difference between an observation and its corresponding simulated value) that have the same measurement units, whether the residual is for water levels or streamflow gain/loss. Model calibration that uses water-level and streamflow gain/loss residuals in the same measurement units allows both types of residuals to be included in the sum of squared errors that the automated parameter-estimation process attempts to minimize. Weights on observation data account for measurement error associated with the accuracy of the sampling device, method of determining land surface, effects of recent water withdrawals, uncertainties in the actual screened intervals of some wells, and other factors. In theory, weights on the observations used in the regression procedure can be calculated from estimates of the variance or standard deviation of measurement error (Hill, 1998, p. 45-47). The weights are proportional to 1 divided by the variance of the measurement errors for the observation. To estimate these variances, the UCODE_2005 program applies statistics on measurement error from which the variances of the observation errors are calculated. The standard deviation of the measurement error was used as the statistic to estimate the weights for water-level observations, and the coefficient of variation was used for the streamflow gain/loss measurements. The calculations of the statistics are described in Hill (1998, p. 46-47).

Weights for the water-level observations were based on the assumption that 95 percent of the measurements were within the measurement error, which was considered to be $0.01 \mathrm{ft}$. Statistical theory for normally distributed populations states that for the 95-percent confidence interval, the measurement error should be 1.96 times the standard deviation of the measurement error (Cooley and Naff, 1990, p. 44). The standard deviation of the measurement error is, therefore, equal to 0.0153 (0.01 divided by 1.96); the standard deviation of the measurement error is used as an input to UCODE_2005 for calculating water-level weights. The weight for the streamflow observation at CS-1 was calculated by using an estimated coefficient of variation value of 0.2 ; this assumes a standard deviation of 20 percent of the measurement made at the site.

\section{Changes in the Design of the Model During Calibration}

The calibration process resulted in the following changes to the model design, which produced more reasonable model output and reduced model complexity.

1. The extent of recharge zones was generalized. At first, the extent of specific recharge zones was derived from a land-use grid. The resulting recharge distribution consisted of many areas of abrupt changes in recharge rates, and different recharge parameters were assigned to basically the same area. It was later decided that a given area dominated by one land use should have the recharge rate associated with the dominant land use. The change in the design of recharge rate distribution led to improved parameter estimation of recharge rates.

2. Hydraulic-conductivity parameters for fill materials in different parts of the model area were not included in the final model. Hydraulic-conductivity parameters were created for several fill materials associated with roads and the filtration pond boundary. The model was insensitive to changes in hydraulic-conductivity parameters for fill materials. In the final design, the fill materials were described as having the same hydraulic conductivity as the surficial sand aquifer.

3. A layer of the model that simulated the organic sediments associated with wetlands in the modeled areas and that lie at the bottom of Long Lake was not included in the final model. It was concluded through the parameter-estimation process that the organic sediments represented by these parameters do not extend vertically over a sufficient extent of the surficial aquifer to affect overall groundwater flow. Simulation results from the model were insensitive to changes in parameters assigned to the organic sediments; in the final design, the organic sediments were described as having the same hydraulic conductivity as the surficial sand aquifer.

4. Layers of the model originally intended to simulate a confining unit and confined aquifer within the study area were replaced with zones of decreased hydraulic conductivity. The extent of the confining unit is unknown. Removing the layers that simulate the confining unit simplified the model. 


\section{Calibration Results}

This section provides the final calibrated values for model parameters for the dry-weather (October 2002) simulated condition, indicates how the model simulates observed values of water level and streamflow with its calibrated parameter values, and presents a simulation of the groundwater flow system as represented by the model.

\section{Calibrated Parameter Values}

The initial and calibrated values for all parameters are listed in table 8 . The final parameter value for the hydraulic conductivity of the surficial sand aquifer (ks) was $21.34 \mathrm{ft} / \mathrm{d}$, whereas the value of the parameter that represents the hydraulic conductivity of the less permeable basal sand aquifer (ks_dirty) is $4.00 \mathrm{ft} / \mathrm{d}$. The final parameter value that represents the recharge to the aquifer system in the undeveloped areas of the model domain is $7.92 \mathrm{in} / \mathrm{yr}$, the recharge to the aquifer system in wetland areas of the model domain is $5.61 \mathrm{in} / \mathrm{yr}$, and the recharge to the aquifer system in urban areas of the model domain is $-1.01 \mathrm{in} / \mathrm{yr}$. The negative recharge value simulates leakage from the aquifer system to the sewer system in urban areas within the surficial aquifer. Leaky sanitary and storm sewers were indicated within the city of Gary by a prior groundwater flow simulation west of the study area (Fenelon and Watson, 1993).

\section{Model Fit to Observations}

The calibrated groundwater flow model accurately simulated water levels and streamflow gain/loss in the actual flow system during low-flow conditions, as measured by a correlation coefficient of nearly 1.0 between weighted observations of water levels and streamflow gain/loss and weighted simulated equivalents computed by the model. The degree of fit between field-observed values and model-simulated values is an indication of how well the model simulates the observed conditions of the groundwater flow system. Model fit is measured in multiple ways, including correlation coefficients of weighted simulated values with weighted observed hydrologic measurements; for example, water levels and streamflow gain/ loss and plots of simulated with observed hydrologic measurements and their residuals. Residuals in this case are the difference between the observed dry-weather conditions of October 2002 and the model-simulated values. Ideally, model values should be close to observed values such that when weighted observations are plotted against weighted simulated values, the points should fall close to a line with slope equal to 1 and intercept of 0 . The correlation coefficient between weighted observations and weighted simulated equivalents reflects how close the points plot along the line. A value greater than 0.90 is desirable and the model calibration to the dry-weather data resulted in a value of nearly 1.00. A plot of both unweighted simulated values with unweighted observed values and weighted simulated values with weighted observed values is shown in figures $23 A$ and $23 B$.
The calibrated groundwater flow model also met two other criteria that are required of valid models. The weighted residuals or difference of weighted simulated water levels and streamflow gain/loss and their weighted observed values were determined to plot along a straight line with a correlation coefficient of 0.980 , close to the desired 1:1 relation. Two types of weighted-residual plots that illustrate these model characteristics are shown in figure 23. In part $C$ of the figure, the weighted residuals are plotted according to their position in an assumed normal distribution. If the weighted residuals are normally distributed (a requirement for valid parameter estimation), then they should plot along a straight line. The statistic that measures the linearity of the plot, as well as the independence of one residual from another, is called the correlation between ordered weighted residuals and normal order statistics. This correlation coefficient also should be near 1 , and the value associated with the calibration is 0.953 ; the weighted residuals plot generally along a straight line. In part $D$ of figure 23, weighted residuals are plotted with their simulated values. Ideally, the weighted residuals should be evenly distributed around 0 (no difference between weighted simulated and weighted residual values) and the size of the weighted residuals should not relate to the magnitude of the simulated values (for example, large residuals should not be associated with lower simulated values). These requirements are generally satisfied.

To display the more important error associated with the simulated water levels, the axes on the residual plots on figures $23 C$ and $23 D$ were chosen to show only the weighted residuals that represent water levels. The residual plots do not show the residual associated with measured streamflow gain/ loss because the streamflow gain/loss residual plots near the origin of the axis, whereas the water-level residuals plot farther from the origin. Showing all residuals on figures $23 C$ and $23 D$ would result in clumped data points, and details of the distribution of the water-level residuals would be obscured. The streamflow gain/loss residuals plotted near the 1:1 line for the figure $23 C$ plot and near the zero line for the figure $23 D$ plot indicating its small contribution to model error.

Small overpredictions and underpredictions of water levels by the model are relatively scattered in their geographic distribution across the model area (fig. 24). Unweighted residuals can be analyzed by their areal distribution, range, and magnitude; unweighted water-level residuals are the actual difference between measured and simulated water levels with no weighting factor applied. The unweighted water-level residuals are shown in figure 24 for the dry-weather simulation to depict the mixed nature of positive and negative residuals in different parts of the model area, which is characteristic of an adequately calibrated model. Residuals in the areas surrounding East and West Long Lake near the center of the model are mostly negative but are close to zero, indicating that the model is simulating observed conditions much more closely in these areas of greater interest than in areas further away from the center of the model.

Simulated water levels and streamflow gain/loss data are very similar to the observed data, as indicated by several 
statistics that compare them. Computed statistics based on the unweighted water-level residuals are presented in table 10. The range of unweighted water-level residuals can be expressed by their standard deviation, and the standard deviation of the residuals for the calibration is $0.69 \mathrm{ft}$. Almost 75 percent of the residuals are within 1 standard deviation of the mean residual, and more than 90 percent are within 2 standard deviations. The magnitude of water-level residuals can be represented by the mean absolute error, or the mean of the magnitudes of the water-level residuals, which is $0.52 \mathrm{ft}$. The relative accuracy of the model calibration can be measured by the percent mean absolute error, which is the mean absolute error divided by the overall range in water levels. The percent mean absolute error for the model was 2.96 percent. The measured flow from US-12 ditch was $0.257 \mathrm{ft}^{3} / \mathrm{s}$, and the simulated flow was $0.310 \mathrm{ft}^{3} / \mathrm{s}$. Although no discharge was measured in 2002 from County Line Road ditch, simulated discharge from
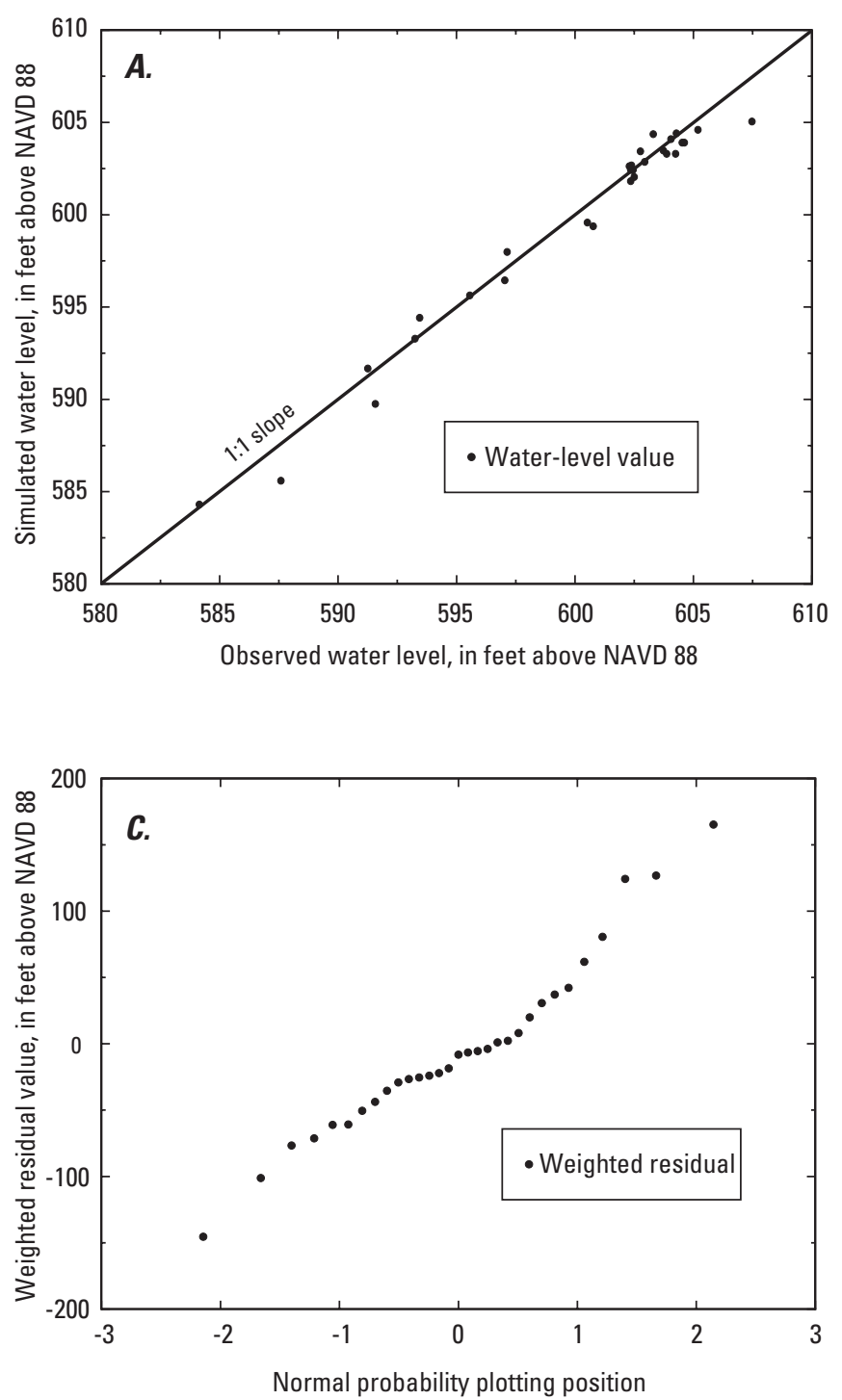

the ditch was $0.175 \mathrm{ft}^{3} / \mathrm{s}$, which is reasonable considering the size of the stream.

Weighted residuals were used to determine that the overall fit of the groundwater flow model was within $1 \mathrm{ft}$. Weighted residuals can be used to determine a measure of model fit for water levels and streamflow gain/loss that includes error in the measurement of the observations. The weighted residuals are used to calculate the standard error of the regression. The standard error of the regression for the model is dimensionless, so it is multiplied by the standard deviation of waterlevel measurement error to obtain a measure of overall model fit for water levels. The standard error for the model for the dry-weather simulation is 94.16 , and the standard deviation of measurement error for water levels is 0.01 ; therefore, the overall model fit is $\pm 0.94 \mathrm{ft}$. An estimate of model fit to flow observations is not possible because only one flow observation was considered useful for calibration, and a single value is insufficient for this method.
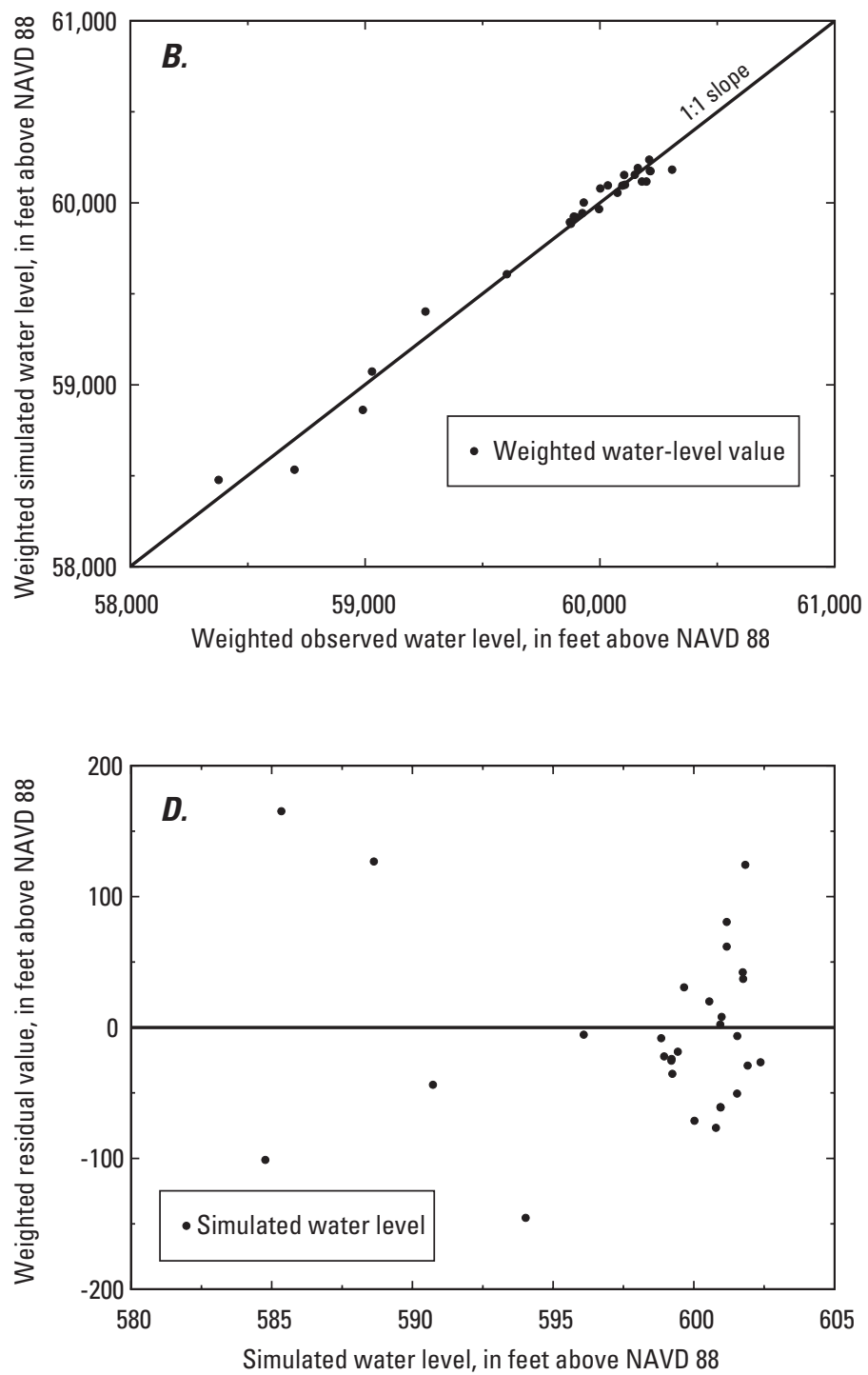

Figure 23. Graphical analysis of model fit. $A$, Simulated and observed water levels. $B$, Weighted simulated and weighted observed water levels. $C$, Normal probability plot of weighted residuals. $D$, Weighted residuals and simulated water levels. 


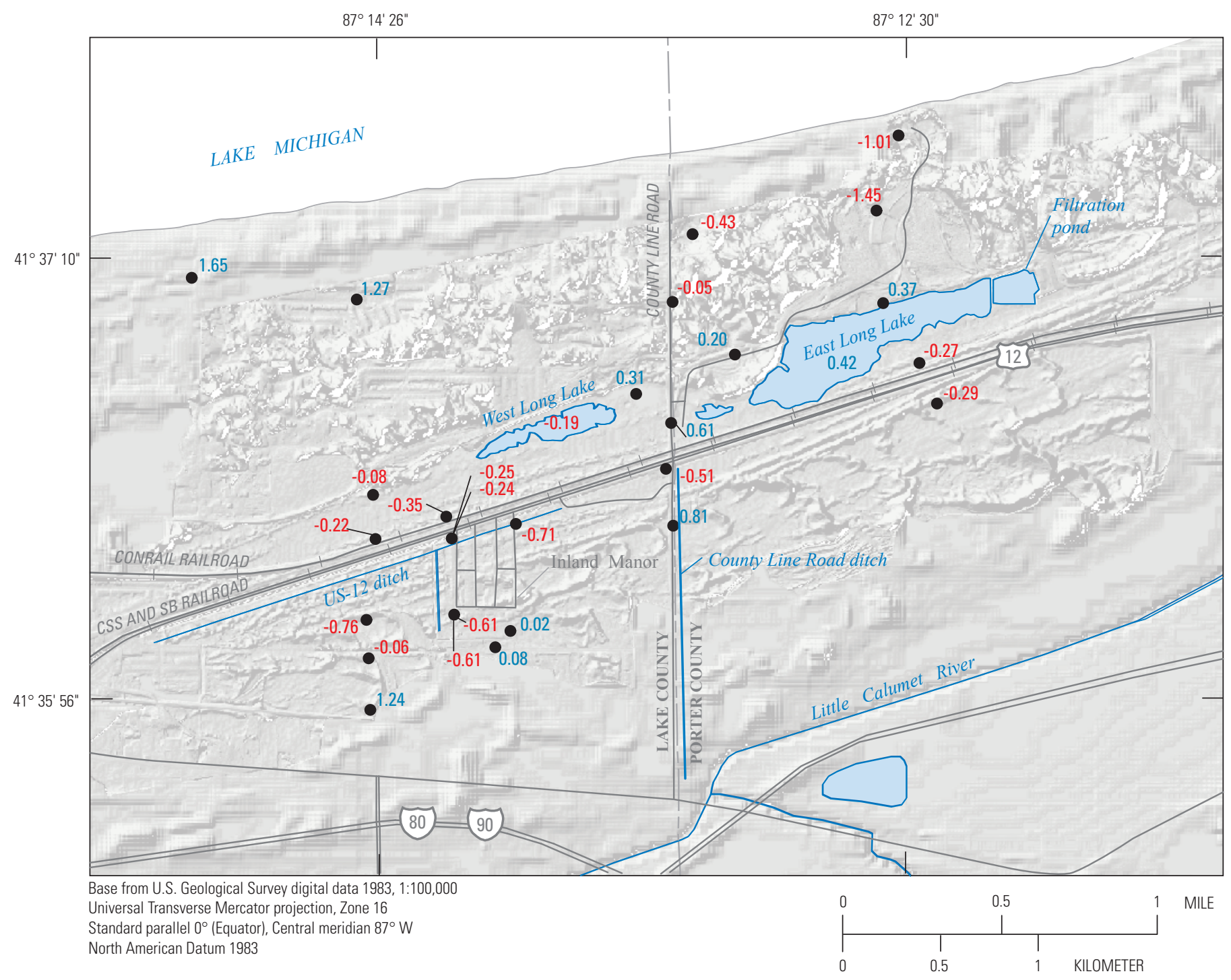

\section{EXPLANATION}
1.65 Location of an observation well with a positive residual; at these locations,
- 1.65 the groundwater flow model underestimated the water level in the observation well

-1.45 Location of an observation well with a negative residual; at these locations, well

Figure 24. Difference between observed and simulated water levels for the calibrated dry-weather (0ctober 2002) groundwater model of the area near Long Lake, Indiana Dunes National Lakeshore, Indiana. 
Table 10. Computed statistics based on the water-level residuals for the dry-weather (October 2002) calibrated groundwater model.

[ft, feet; $\mathrm{ft}^{3} / \mathrm{s}$, cubic feet per second]

\begin{tabular}{|c|c|c|c|c|c|c|c|}
\hline \multirow[b]{2}{*}{$\begin{array}{l}\text { Type of } \\
\text { residual }\end{array}$} & \multicolumn{7}{|c|}{ Statistics based on unweighted model residuals } \\
\hline & $\begin{array}{l}\text { Minimum } \\
\text { residual } \\
\text { (ft) }\end{array}$ & $\begin{array}{l}\text { Mean } \\
\text { residual } \\
\text { (ft) }\end{array}$ & $\begin{array}{l}\text { Maximum } \\
\text { residual } \\
\text { (ft) }\end{array}$ & $\begin{array}{c}\text { Standard } \\
\text { deviation of } \\
\text { the residuals } \\
\text { (ft) }\end{array}$ & $\begin{array}{c}\text { Bias } \\
(\mathrm{ft})\end{array}$ & $\begin{array}{l}\text { Mean } \\
\text { absolute } \\
\text { error } \\
\text { (ft) }\end{array}$ & $\begin{array}{c}\text { Percent } \\
\text { mean } \\
\text { absolute } \\
\text { error }\end{array}$ \\
\hline Water level & -1.45 & -0.04 & 1.65 & 0.69 & -1.13 & 0.52 & 2.96 \\
\hline $\begin{array}{l}\text { Type of } \\
\text { residual }\end{array}$ & $\begin{array}{c}\text { Drainage } \\
\text { feature name }\end{array}$ & $\begin{array}{c}\text { Observed } \\
\left(\mathrm{ft}^{3} / \mathrm{s}\right)\end{array}$ & $\begin{array}{l}\text { Simulated } \\
\left.\left(\mathrm{ft}^{3} / \mathrm{s}\right)\right)\end{array}$ & $\begin{array}{c}\text { Residual } \\
\left(\mathrm{ft}^{3} / \mathbf{s}\right)\end{array}$ & & & \\
\hline Streamflow & US-12 ditch & -0.26 & -0.31 & 0.05 & & & \\
\hline
\end{tabular}

\section{Simulated Water Budget}

The resulting calibrated model can be quantified and analyzed by an overall water budget and by a budget for individual parts of the flow system. Table 11 lists the overall budget for the dry-weather simulation. The influx of water into the model comes predominantly from aerial recharge values assigned during the calibration process across the extent of the model to simulate precipitation and simulated infiltration from the filtration pond. To a lesser extent, water also enters the model from the bedrock aquifer below across the head-dependent boundary and the constant-head boundary that simulates Lake Michigan. A large portion (49 percent) of the discharge from the model goes to the Little Calumet River rather than to Lake Michigan (40 percent). If flow to the lagoons were included with streamflow, then the percentage of flow to streams would increase. A small portion ( 7.5 percent) of the discharge from the model goes to the ditches (drains) simulated in the model.

The budget between the model and the three water bodies-East Long Lake, West Long Lake, and the filtration pond-was analyzed, and the results are shown in figure 25 . Less than 6 percent of the water entering the aquifer is from the water bodies, and most of that water is from the filtration pond. Of greater significance is that 10 percent of all the water entering East Long Lake is from the filtration pond and 90 percent is from recharge by precipitation and from groundwater discharge to the lake. Also, flow from the filtration pond to East Long Lake is nearly one-fifth the flow from the surficial aquifer to the lake. The filtration pond represented a substantial source of water to the lake.

Table 11. Water budget associated with the dry-weather (October 2002) calibrated model.

$\left[\mathrm{ft}^{3} / \mathrm{s}\right.$, cubic feet per second; $\%$, percent]

\begin{tabular}{|c|c|c|c|c|c|}
\hline \multirow{2}{*}{$\begin{array}{c}\text { Inflow to model } \\
\text { Lake Michigan and Grand Calumet } \\
\text { lagoons (Constant-head boundaries) }\end{array}$} & \multicolumn{2}{|c|}{$\begin{array}{c}\text { Inflow rate }\left(\mathrm{ft}^{3} / \mathrm{s}\right) \text { and } \\
\text { percent of total }\end{array}$} & \multirow{2}{*}{$\begin{array}{c}\text { Outflow from model } \\
\text { Lake Michigan and Grand Calumet } \\
\text { lagoons (Constant-head boundaries) }\end{array}$} & \multicolumn{2}{|c|}{$\begin{array}{c}\text { Outflow rate }\left(\mathrm{ft}^{3} / \mathrm{s}\right) \text { and } \\
\text { percent of total }\end{array}$} \\
\hline & 0.31 & $(4.76 \%)$ & & 2.59 & $(39.89 \%)$ \\
\hline & & & $\begin{array}{l}\text { Leakage into US-12 ditch, County Line } \\
\text { Road ditch, Unnamed Tributary to } \\
\text { Little Calumet River (Model drains) }\end{array}$ & 0.49 & $(7.49 \%)$ \\
\hline Bedrock (Head-dependent boundary) & 0.03 & $(0.46 \%)$ & Bedrock (Head-dependent boundary) & 0.03 & $(0.46 \%)$ \\
\hline Precipitation (Recharge) & 6.15 & $(94.73 \%)$ & Leakage to sewers (Recharge) & 0.18 & $(2.78 \%)$ \\
\hline Total inflow & 6.49 & & Total outflow & 6.49 & \\
\hline
\end{tabular}




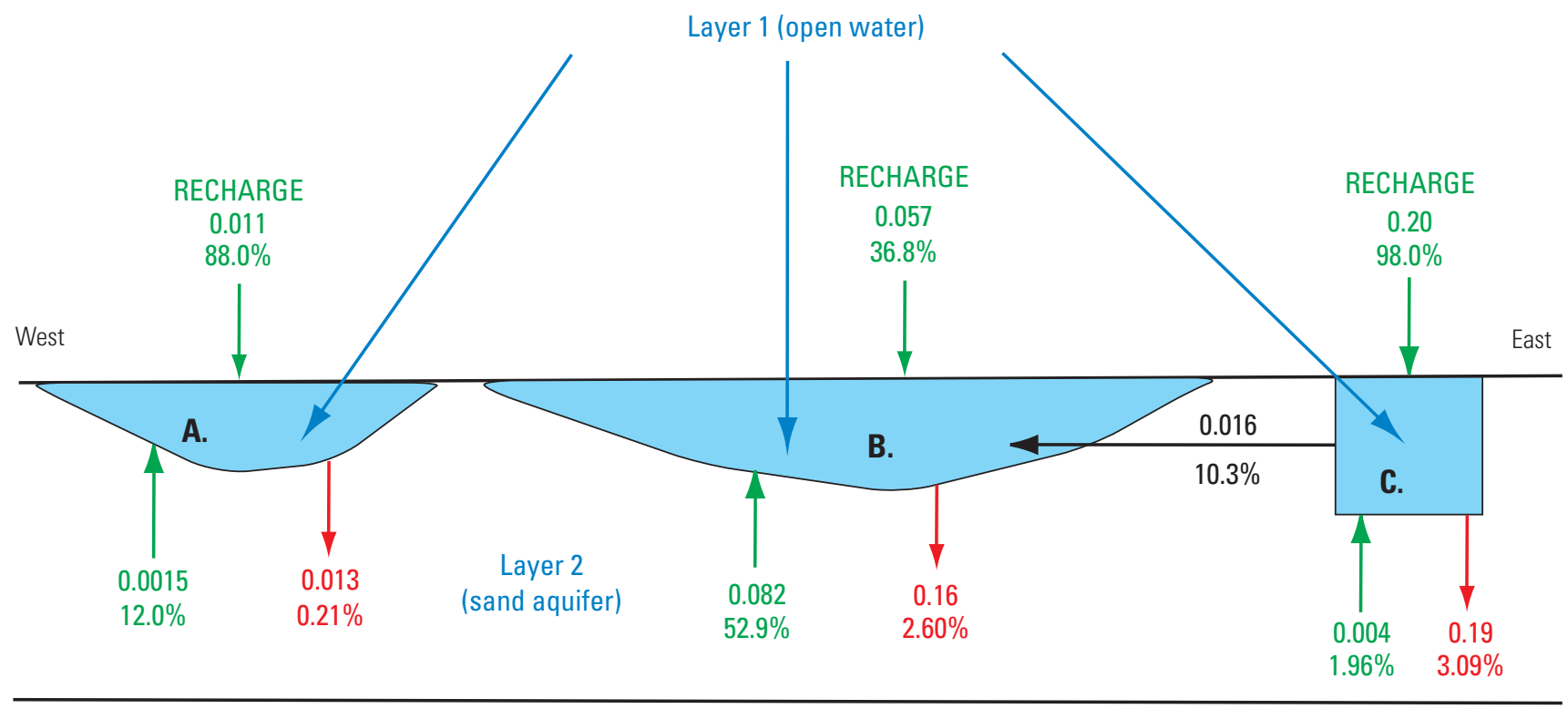

\section{EXPLANATION}

\section{A. West Long Lake \\ B. East Long Lake \\ C. Filtration pond}

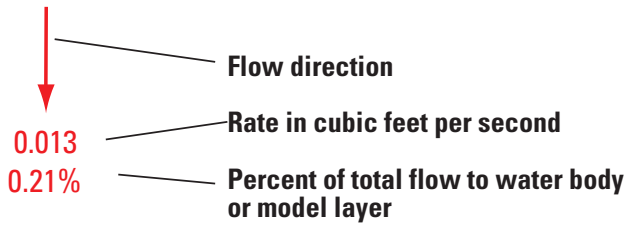

Figure 25. Flow interchange among the model and East Long Lake, West Long Lake, and the filtration pond for the calibrated dryweather (October 2002) groundwater flow model.

\section{Simulated Water Levels and Groundwater Flow Paths}

The results of the groundwater flow model show that the filtration pond is a major source of recharge to the surficial aquifer under dry-weather (October 2002) conditions and that the US-12 ditch is a major discharge zone for the groundwater system. The groundwater flow system can be illustrated by water-level contours from which direction of flow can be inferred. Simulated water-level contours are presented in figure 26 for the dry-weather (October 2002) calibrated model. The major flow paths in the vicinity of East Long Lake trend mostly north to Lake Michigan and to the south to the Little Calumet River. The groundwater divide between the two paths is south of West Long Lake and US-12 ditch, south of East Long Lake, and through the middle of the filtration pond- the area of highest groundwater levels is at the filtration pond on the eastern side of East Long Lake. The ditch along US-12 represents a localized zone of discharge as evidenced by the area of low water levels surrounding the ditch. The other discharge zone is north to Lake Michigan from the north side of US-12 ditch. County Line Road ditch has little to no effect on water-level contours and does not affect water levels much in the dry-weather simulation.
Groundwater flow paths, which are perpendicular to the water-level contours, provide useful information about the source, distribution, and discharge of groundwater. Backtracking flow paths were generated in every node ${ }^{3}$ around the model perimeter and for nodes representing the US-12 ditch using MODPATH (Pollock, 2012); results are shown in figure 27. MODPATH, a particle-tracking post-processing package for MODFLOW, computes paths for imaginary particles of water moving through the simulated groundwater system. To create backtracking flow paths, the model, for each node specified, calculates a starting point for groundwater that ultimately ends up at the specified node. This allows for the calculation of the areas contributing flow to features of interest. For example, by specifying each node assigned to simulate the US-12 ditch, an area can by delineated that supplies water to the ditch. The resulting flow paths generally extend north and south, just as would be interpreted from the contours in figure 26, but additional details in flow can be seen. The area contributing water to the US-12 ditch does not include either East or West Long Lake. The majority of the contributing area to the US-12 ditch is south and southwest of the ditch. Some flow from areas immediately to the north of the ditch may contribute to

\footnotetext{
${ }^{3} \mathrm{~A}$ node is the point within a model cell at which head is calculated.
} 


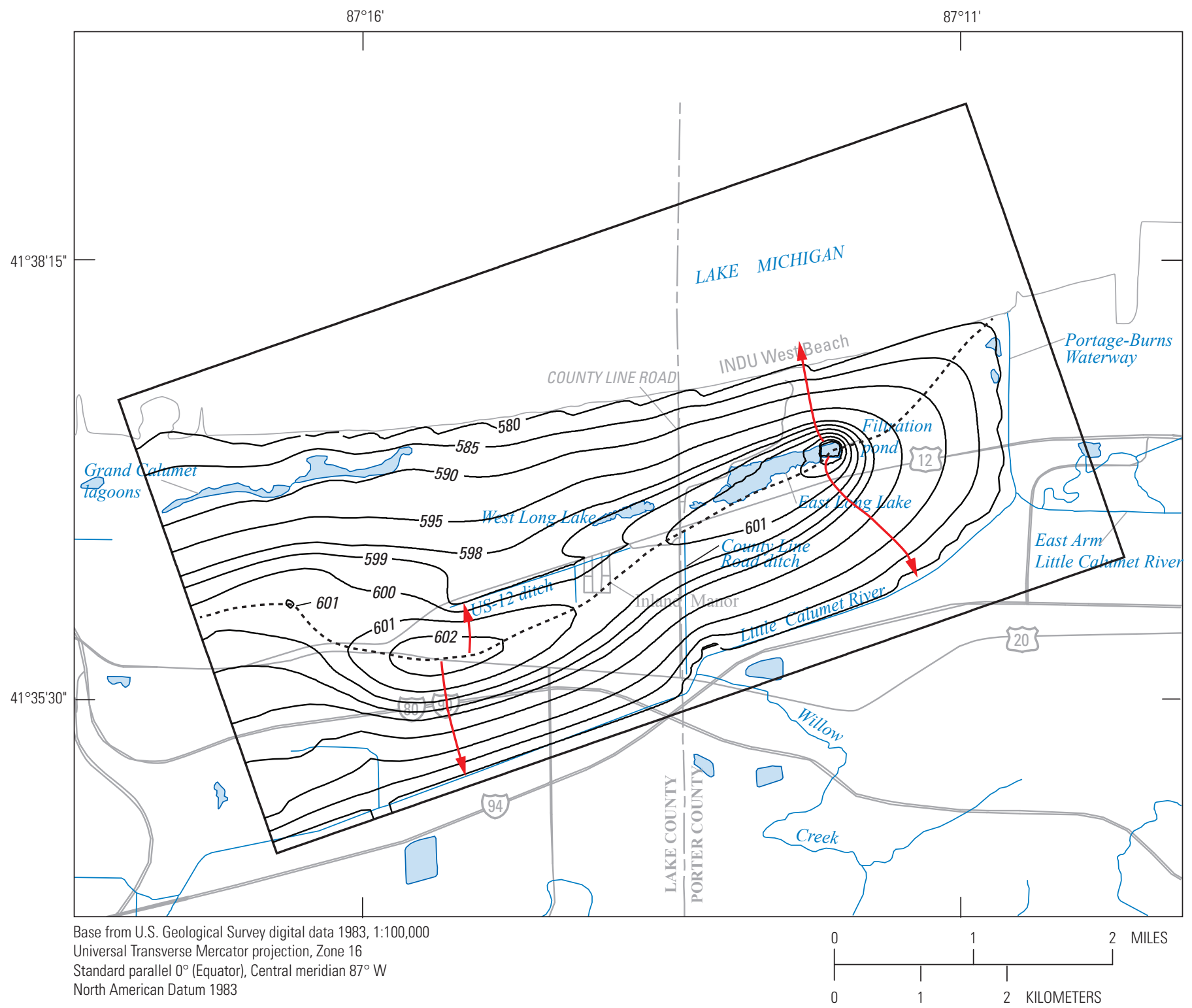

EXPLANATION

Simulated water-table contour-Shows the altitude of the water

-601_ table in feet above NAVD 88 simulated by the groundwater flow model in the surficial aquifer. Contour interval variable

\section{Arrow indicating direction of groundwater flow inferred from simulated} water-table contours

Groundwater divide-Approximate simulated divide in surficial aquifer, October 16, 2002

Figure 26. Simulated water-table contours from the dry-weather (October 2002) calibrated model. 


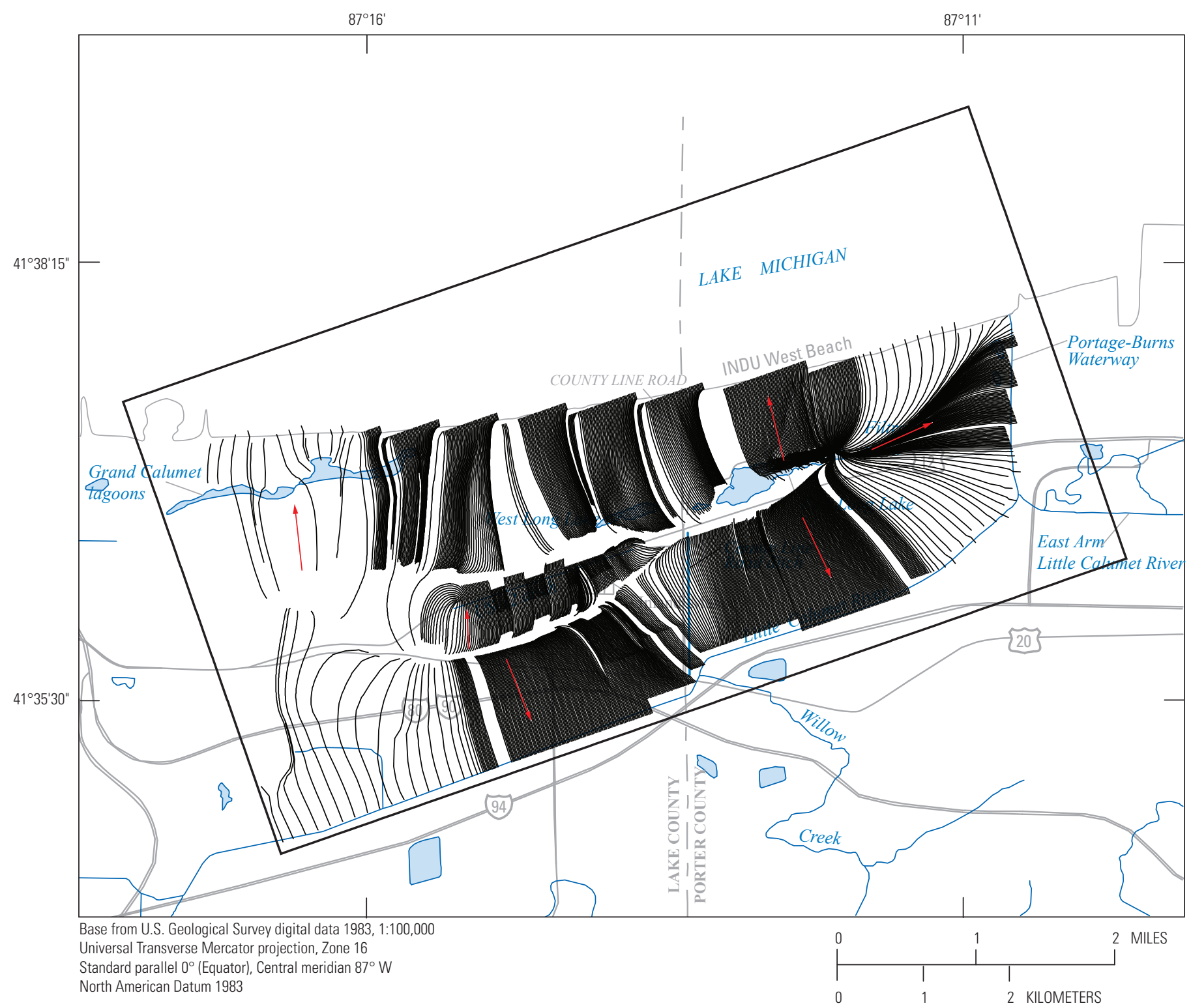

\section{EXPLANATION}

Horizontal groundwater flow path within the surficial sand aquifer.

Arrow indicating general direction of groundwater flow simulated by the dry-weather groundwater flow model

Figure 27. Flow lines representing simulated groundwater flow paths in the surficial aquifer under steady-state dry-weather conditions, 0ctober 2002. Arrows represent general directions of simulated groundwater flow. 
flow within US-12. Some flow paths travel westward from the filtration pond to East Long Lake, northward to Lake Michigan, and to the south toward the Little Calumet River.

In figure 28 , the vertical distribution of the flow lines just discussed is shown at two north-south cross sections, one along model column 93 beneath US-12 ditch and the other along column 290 beneath East Long Lake (locations shown in fig. 17). Both sets of flow lines show the same pattern of mostly downward-directed vertical flow near groundwater divides and mostly horizontal flow away from the divides.

Simulation results indicate that the majority of water discharging from US-12 ditch originates from wetland areas to the south of the ditch and that East Long Lake functions as a "flow-through" lake during the dry-weather (October 2002) simulation. In figure $28 \mathrm{~A}$, flow from a large area to the south of US-12 ditch and smaller areas to the north of the ditch discharges horizontally and vertically upward into the ditch. Flow lines on the south side of the southern groundwater divide flow to the Little Calumet River to the south and north of the northern groundwater divide flow to the north to Lake Michigan. In figure $28 \mathrm{~B}$, flow lines near the groundwater divide discharge to East Long Lake, but some continue beneath and eventually discharge to Lake Michigan. East Long Lake and West Long Lake do not appear to capture water from as great an area as the ditch, probably because the lakes are not as entrenched into the groundwater flow system as is the ditch.

\section{A. Column 93}

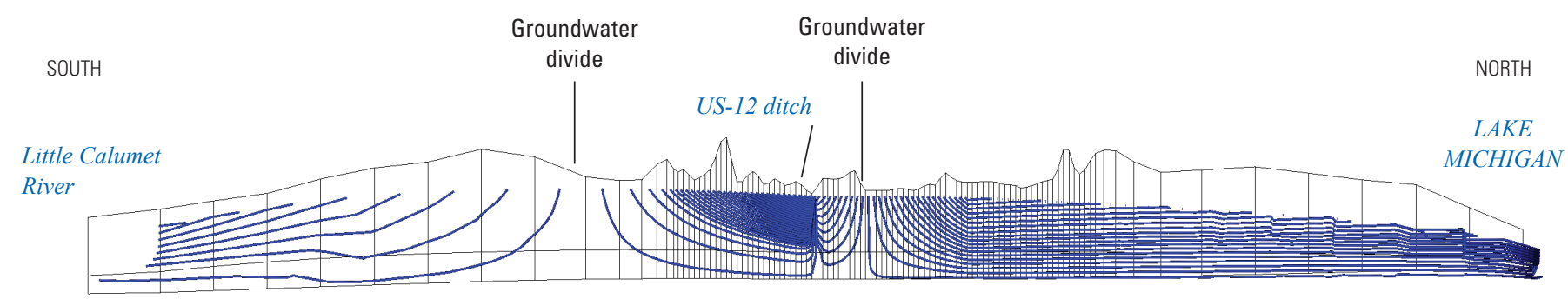

EXPLANATION

Groundwater flow path
B. Column 290
Groundwater
divide

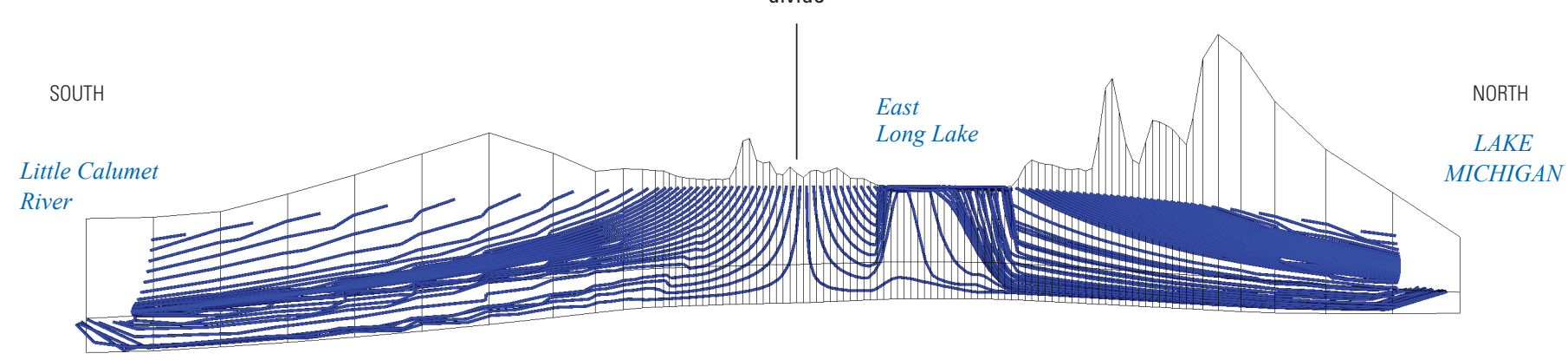

\section{EXPLANATION}

Groundwater flow path

Figure 28. Vertical flow paths simulated with the dry-weather (October 2002) calibrated model. A, Flow paths along column 93 and through the US-12 ditch. B, Flow paths along column 290 and through East Long Lake. 


\section{Simulated Inundated Areas}

Inundated areas (areas where the water table is simulated to be above the land surface) and areas where the water table is simulated to be within $7 \mathrm{ft}$ of the land surface (the estimated altitude of typical basements or other below grade structures) are displayed in figure 29 to help describe the differences in the simulated extent of East and West Long Lake between the simulated dry-weather condition and other simulated scenarios. Inundated areas were calculated by using the altitude of the simulated, steady-state water table and land-surface elevation as complied from datasets with resolution of 98.4 $\mathrm{ft}(30 \mathrm{~m})$ and $9.8 \mathrm{ft}(3 \mathrm{~m})$ (fig. 19). The digital land-surface altitude was subtracted from the water-table altitude to calculate the depth of the water table above the land surface. At the point where the water table rises above land surface, surface runoff should be generated. Because of this, the actual area where water levels rise above ground surface may be smaller than the area shown in figure 29, even though the amount of surface runoff is estimated to be small because of the high permeability of the materials at land surface. Imprecision in land-surface altitude in some of the areas represented also adds to the uncertainty of the estimated area of inundation for parts of the model.

Water levels in most areas west of County Line Road except along the US-12 ditch are simulated to be below the land surface. The areas with ponded water are in and surrounding the filtration pond west of Ogden Dunes and east of East Long Lake, plus areas immediately south of the filtration pond. Several developed areas are within parts of the model with areas of simulated water levels between 0 and $7 \mathrm{ft}$ below land surface during the dry-weather simulated condition. These include areas near the southwestern corner of Ogden Dunes and parts of Gary that extend about $0.25 \mathrm{mi}$ west of the western end of the US- 12 ditch and about 0.2 mi north and south of US-12.

\section{Sensitivity Analysis}

The purpose of a sensitivity analysis is to determine the parameters that are more important to water levels and streamflow gain/loss predictions within the model. If certain parameters substantially affect simulated water levels, then these parameters are important to accurate model predictions. The process of automated parameter estimation provides three types of sensitivity-related data: dimensionless scaled sensitivity, one-percent scaled sensitivities, and composite scaled sensitivities (Hill, 1998, p. 14-16; Hill and Tiedeman, 2007, p. 46-56).

The three types of sensitivity data reflect the degree of change in water levels for a given change in a parameter value. The dimensionless scaled sensitivity numbers can be used to compare the importance of different observations to the estimation of each of the parameters, a comparison that is useful during calibration. One-percent scaled sensitivities measure the variation in sensitivity of observations to a parameter throughout the model. One-percent scaled sensitivities are calculated for each node of the model, and the sensitivities can be mapped. The areas of larger sensitivity for a parameter are good locations for obtaining additional observations to improve the estimate of the parameter. The composite scaled sensitivities (CSS) measure the sensitivity of model output to variations in a given model parameter on the basis of the available set of observations. Larger values of CSS associated with a specific parameter mean that the available observations are more useful in estimating those parameters.

The CSS values for the calibrated model parameters are listed in table 8 . A high CSS value indicates that the observations used in the model are providing enough information to estimate a particular parameter and therefore can be estimated by automated methods. Hydraulic conductivity of the surficial aquifer (ks) and parameters for recharge rates to the aquifer for areas with undeveloped (non-wetland/non-urban), wetland, and urban land covers (rsimp_s, rsimp_w, and rsimp_u) are the major parameters controlling water-level surfaces. All these parameters except rsimp_u have relatively high CSS values, indicating that sufficient observations were available to estimate those parameters. If the major parameters are adequately estimated, then the simulated water-level surfaces have a higher probability of reflecting actual conditions. The CSS value for the parameter used to estimate recharge in urban areas is low, most likely because of the small number of observation wells in that particular recharge zone. Although the CSS value was small, the parameter estimation process was used to calculate an initial parameter that was then finalized by using manual techniques, including trial-and-error adjustment of the estimated parameter value. If the adjustment of any parameter resulted in new values that achieved lower total root mean square (RMS) error values for both head and flow observations, the adjusted parameter value was assigned as the final value.

Significant correlations between parameters are also listed in table 8 . The parameter representing the hydraulic conductivity of the surficial aquifer $(\mathrm{ks})$ is correlated to parameters for recharge rates to the aquifer for areas with undeveloped (non-wetland/non-urban), wetland, and urban land covers (rsimp_s, rsimp_w and rsimp_u). Even though the use of parameter estimation techniques is not recommended on parameters that are correlated with each other, these techniques were used on these parameters to assist in model calibration. Once final parameter values were determined, the parameter estimation process was repeated with different starting values for these parameters which resulted in values equal to the previously determined final parameter values.

The sensitivity of the model to features of the model design, such as boundary conditions or the extent of the model grid, was not tested. The part of the model area that is active is bounded by major hydrologic features, with Lake Michigan to the north and the Little Calumet River to the south and east. Changing the extent of the model grid or the boundary conditions that represent these features would likely not affect the results of the simulation. 


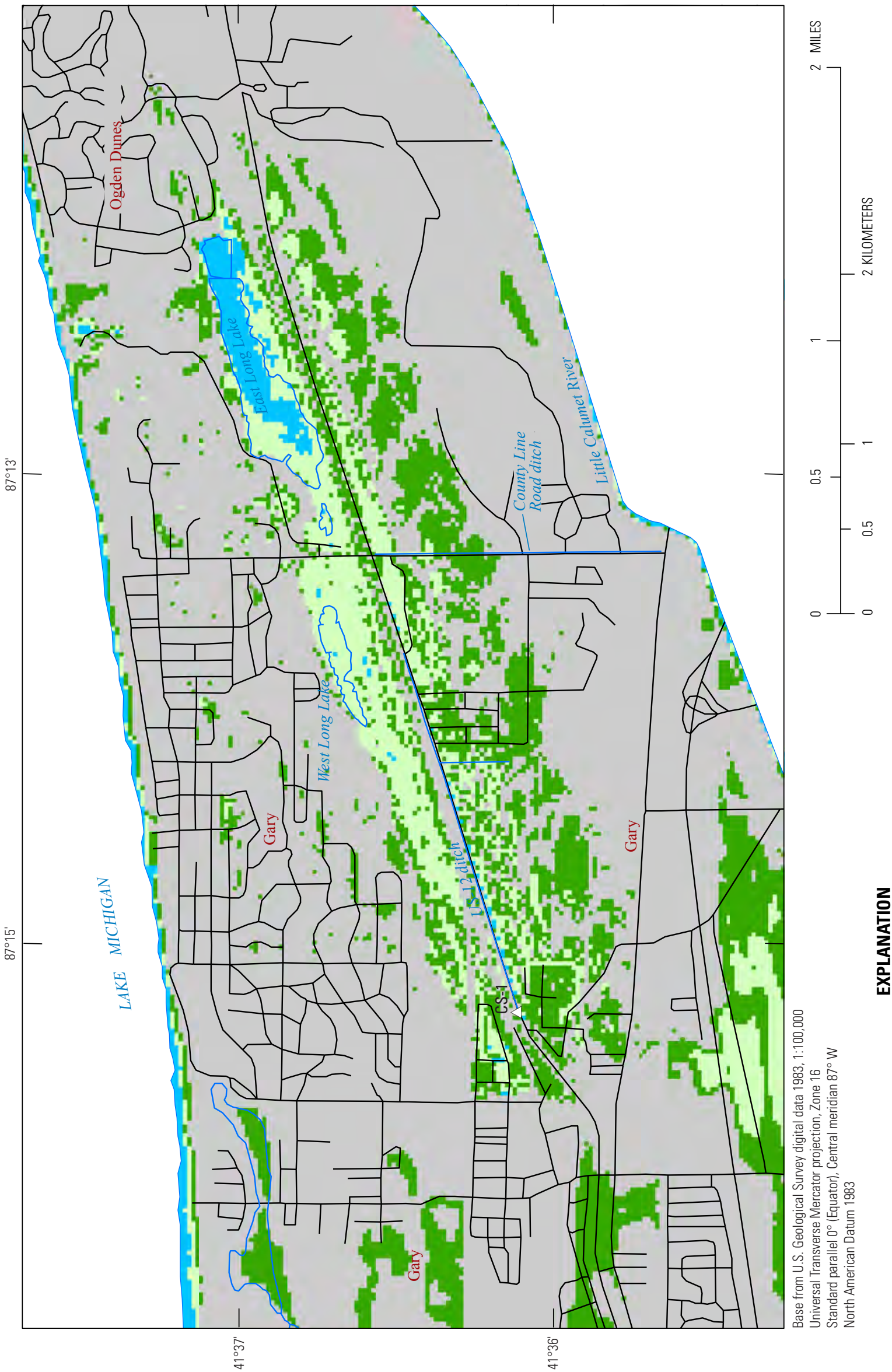

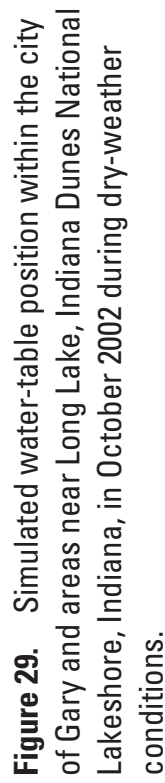

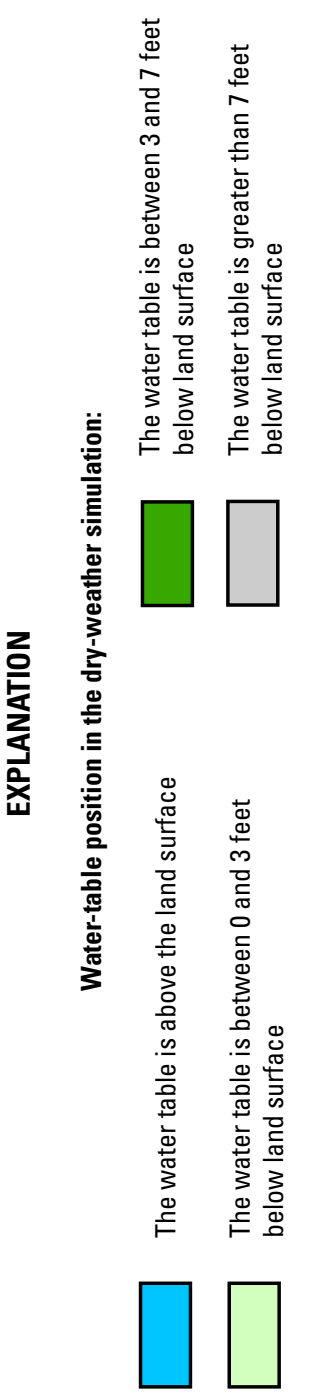




\section{Model Simulations of Climatic Effects and Hydrologic Modifications to Long Lake Watershed}

As described earlier in this report, the hydrologic condition of the study area can be described as dry weather in October 2002 and wet weather in March 2011. In addition to the groundwater flow model of the dry-weather (October) 2002 hydraulic condition, an additional simulation was created by using water levels measured during the wet-weather (March 2011) condition. Several other scenarios also were run with the groundwater flow model to simulate the effects of various drainage modifications and climatic conditions on the simulated hydrology in the modeled area. In most cases, these scenarios were simulated under both the dry-weather (October 2002) and the wet-weather (March 2011) conditions.

Simulated drainage modifications and engineering controls were the following:

1. Removing the beaver dams in US-12 ditch from the wetweather (March 2011) simulation. The simulated conditions of this scenario would allow increased amounts of flow through the ditch and into the GSD sewer system but would also make water levels lower in the areas upstream of the beaver dams where water ponds, affecting basements and other subgrade structures.

2. Removing the influx of water from the filtration pond on the east side of East Long Lake. The conditions tested in this scenario were applied only to the results from the dryweather (October 2002) simulation where the elimination of seepage from the filtration pond during dry conditions could affect the extent of East and West Long Lake and surrounding wetlands.

3. Discontinuing the discharge of water from the US-12 ditch to the GSD sewer system. This is simulated by removing the drain cells that represent US-12 ditch from the groundwater flow model. Discontinuing this flow would eliminate water entering the GSD sewer system but could also make water levels rise in the areas surrounding the ditch and affect basements and other subgrade structures. This scenario was run under both dry-weather (October 2002) and wet-weather (March 2011) conditions.

4. Decreasing the discharge from the US-12 ditch to the GSD sewer system. This was simulated by increasing the elevation of the drain cells that represent the US-12 ditch, effectively increasing the amount of water allowed to pool behind the concrete drop structure at the western terminus of the ditch. Reducing this flow would also reduce the amount of water flowing into the GSD sewer system from the current condition, but it may also increase the water levels in the areas surrounding the ditch. This scenario was run under both dry-weather (October 2002) and wetweather (March 2011) conditions.
5. Connecting East Long Lake to West Long Lake by a culvert underneath County Line Road to create a continuous basin while discontinuing discharge from the US-12 ditch to the GSD sewer system. This scenario was run by using only the wet-weather (March 2011) simulation because the effect on water levels was expected to be greatest during wet conditions; the scenario was simulated by including a single drain cell on the west side of County Line Road that captures water and returns the water to a cell on the east side of County Line Road because, under the originally simulated conditions of this scenario, the water table is at a higher elevation on the west side of County Line Road than the east. Connecting East and West Long Lake would effectively create one body of water with equal elevations of water surface on either side of County Line Road and potentially affect the levels of the water table surrounding both lakes.

6. Deepening the County Line Road ditch. This is simulated by creating a constant slope from the northernmost cell representing the ditch near the intersection of US-12 and County Line Road to the southernmost cell representing the ditch near the Little Calumet River. The conditions of this scenario would effectively move the surface-water divide of the ditch north and would potentially capture groundwater from areas near US-12 and the surrounding wetlands. This scenario was run under both dry-weather (October 2002) and wet-weather (March 2011) conditions.

Two climate-related conditions were simulated:

1. An increase in the water level of Lake Michigan, represented by setting the value of the northern boundary condition of the groundwater flow model equal to the extreme high level of $583.86 \mathrm{ft}$ NAVD 88 recorded on May 31, 1998, at the NOAA Lake Michigan monitoring site at Calumet Harbor, Ill. (period of record March 12, 1905, through September 8, 2011; National Oceanic and Atmospheric Administration, 2011). The conditions of this scenario would simulate the effects of higher Lake Michigan water levels on the water table within the study area during both dry- and wet-weather conditions, using the October 2002 model and March 2011 simulation.

2. A decrease in the water level of Lake Michigan, represented by setting the value of the northern boundary condition of the groundwater flow model equal to the extreme low level of $575.14 \mathrm{ft}$ above NAVD 88 recorded on December 23, 2007, at the NOAA Lake Michigan monitoring site at Calumet Harbor, Ill. (period of record March 12, 1905, through September 8, 2011; National Oceanic and Atmospheric Administration, 2011). The conditions of this scenario would simulate the effects of lower Lake Michigan water levels on the water table within the study area during both dry- and wet-weather conditions, using the October 2002 model and March 2011 simulation. 
Results of these simulated scenarios are presented and compared to the results of other scenarios and, in some cases, with respect to the dry-weather (October 2002) and wetweather (March 2011) simulations. Details of the scenarios that were tested are listed in table 12.

Figures are presented that display (1) areas where the water table is simulated to be at or above the land surface, or equal to a water bodies surface (like Long Lake), (2) areas where the water table is within $7 \mathrm{ft}$ of the land surface, and (3) comparisons of the simulated water table from the various scenarios with the water table from the calibrated, dry-weather (October 2002) model, the wet-weather (March 2011) simulation, or another modeled scenario.

Table 12. Details of various simulated scenarios for both the dry-weather (October 2002) and wet-weather (March 2011) conditions.

\begin{tabular}{|c|c|c|c|}
\hline Scenario & Modification description & $\begin{array}{l}\text { Simulated using dry- } \\
\text { weather (October 2002) } \\
\text { model }\end{array}$ & $\begin{array}{l}\text { Simulated using wet- } \\
\text { weather (March 2011) } \\
\text { simulation }\end{array}$ \\
\hline $\begin{array}{l}\text { Discontinue discharge from US-12 ditch } \\
\text { into sanitary sewer system }\end{array}$ & $\begin{array}{l}\text { Simulated by removing the drain cells that } \\
\text { represent US- } 12 \text { ditch in the groundwater } \\
\text { flow model }\end{array}$ & Yes & Yes \\
\hline Deepen County Line Road ditch & $\begin{array}{l}\text { Simulated by creating a constant slope from } \\
\text { the northernmost cell representing the } \\
\text { ditch to the southernmost cell representing } \\
\text { the ditch }\end{array}$ & Yes & Yes \\
\hline $\begin{array}{l}\text { Increase Lake Michigan level to historical } \\
\text { high water level }\end{array}$ & $\begin{array}{l}\text { Simulated by setting the value of the northern } \\
\text { boundary condition of the groundwater flow } \\
\text { model equal to the historical high value for } \\
\text { Lake Michigan }\end{array}$ & Yes & Yes \\
\hline
\end{tabular}




\section{Simulation of the Wet-Weather Hydrologic Condition in March 2011}

The groundwater flow model built to simulate the October 2002 dry-weather condition was adjusted in two ways to simulate the March 2011 wet-weather conditions:

1. Recharge parameters values were increased from the original values to represent increased precipitation and were decreased at the filtration pond to represent the end of its operation.

2. The elevations of the bottom of the drain cells that represent US-12 ditch were adjusted to account for the locations and relative altitude of four beaver dams in the ditch during the period of data collection.

\section{Adjustment of Parameter Values and Hydrologic Conditions}

Parameters that simulate groundwater recharge in wetland (rsimp_w) and non-wetland/non-urban areas (rsimp_s) were adjusted by using a combination of parameter estimation and manual adjustment from the original values used in the dry-weather (October 2002) simulation (table 13). The value of leakage of water from the filtration pond to the surficial aquifer (rsimp_fp) was set equal to zero because the use of the filtration pond was discontinued in 2009. The value of the parameter representing wetland recharge (rsimp_w) increased $4.31 \mathrm{in} / \mathrm{yr}$, from 5.61 to 9.92 , whereas the value of the parameter representing recharge in non-urban and wetland areas (rsimp_s) increased $0.8 \mathrm{in} / \mathrm{yr}$, from 7.9 to 8.7 . Both values
(9.92 and $8.7 \mathrm{in} / \mathrm{yr}$, respectively) are relatively close and may represent the gradual melting of the snow pack that was evenly distributed across the modeled area previous to the data-collection efforts.

The location and visual estimates of the water-level differences between the upstream and downstream side of four beaver dams in the US-12 ditch were made during the March 2011 data-collection activities. Beaver dams were simulated by adjusting the bottom elevation of drain cells that represent the US-12 ditch to the estimated elevation of the top of the nearest downstream beaver dam. This adjustment limits the amount of water available to pool in the cell to the altitude of the downstream dam. Any water that would potentially pool above this altitude will flow downstream.

\section{Observations}

The observations used for model calibration consisted of 30 water-level measurements and 2 streamflow gain/loss measurements made in March 2011 (table 14). Most water-level observations were in the vicinity of East Long Lake and West Long Lake and the ditch along US-12, but five of the water levels were measured at observation wells in Ogden Dunes. One streamflow gain/loss measurement was made at the end of the ditch along US-12 before water enters the Gary Sanitary District sewer system, two measurements were made along the Little Calumet River, and a single measurement was made in County Line Road ditch (fig. 3). The same techniques for weighting the observations from the calibrated, dry-weather (October 2002) model were used for the wet-weather (March 2011) simulation. 
Table 13. Parameters, their original values, and the adjusted values used to match the wet-weather water-level data collected in March 2011.

[ft/d, feet per day; in/yr, inches per year; ft/s, feet per second; - , parameter not considered for parameter estimation]

\begin{tabular}{|c|c|c|c|c|c|}
\hline Parameter & Parameter description & Parameter type & $\begin{array}{c}\begin{array}{c}\text { October } 2002 \\
\text { dry-weather } \\
\text { calibration }\end{array} \\
\begin{array}{c}\text { Final parameter } \\
\text { value }\end{array}\end{array}$ & $\begin{array}{l}\text { Parameter } \\
\text { estimated using } \\
\text { parameter } \\
\text { estimation for } \\
\text { March } 2011 \\
\text { simulation }\end{array}$ & $\begin{array}{c}\text { March } 2011 \\
\text { wet-weather } \\
\text { simulation }\end{array}$ \\
\hline $\mathrm{kdrn}$ & $\begin{array}{l}\text { Vertical hydraulic conductivity of the } \\
\text { streambed for the ditch along US-12 }\end{array}$ & Drain & $4.7 \mathrm{ft} / \mathrm{d}$ & - & No change \\
\hline kdrn2 & $\begin{array}{l}\text { Vertical hydraulic conductivity of the } \\
\text { streambed for the unnamed tributary to } \\
\text { Little Calumet River }\end{array}$ & Drain & $4.7 \mathrm{ft} / \mathrm{d}$ & - & No change \\
\hline kdrn3 & $\begin{array}{l}\text { Vertical hydraulic conductivity of the } \\
\text { streambed for the ditch along County } \\
\text { Line Road }\end{array}$ & Drain & $4.7 \mathrm{ft} / \mathrm{d}$ & - & No change \\
\hline ks & $\begin{array}{l}\text { Hydraulic conductivity of the surficial } \\
\text { sand aquifer }\end{array}$ & Hydraulic conductivity & $21.34 \mathrm{ft} / \mathrm{d}$ & - & No change \\
\hline ks_dirty & $\begin{array}{l}\text { Hydraulic conductivity of areas simulating } \\
\text { the finer grained basal sand of the aquifer }\end{array}$ & Hydraulic conductivity & $4 \mathrm{ft} / \mathrm{d}$ & - & No change \\
\hline kvl3_dirty & $\begin{array}{l}\text { Vertical hydraulic conductivity of areas } \\
\text { simulating the finer grained basal sand of } \\
\text { the aquifer }\end{array}$ & $\begin{array}{l}\text { Vertical hydraulic } \\
\text { conductivity }\end{array}$ & $0.002 \mathrm{ft} / \mathrm{d}$ & - & No change \\
\hline rsimp_fp & $\begin{array}{l}\text { Recharge rate to the surficial sand aquifer } \\
\text { caused by the filtration pond }\end{array}$ & Recharge & $30,294 \mathrm{in} / \mathrm{yr}$ & No & $0 \mathrm{in} / \mathrm{yr}$ \\
\hline rsimp_gcl & $\begin{array}{l}\text { Recharge rate to the surficial sand aquifer } \\
\text { from the Grand Calumet lagoons }\end{array}$ & Recharge & $0.1 \mathrm{in} / \mathrm{yr}$ & - & No change \\
\hline rsimp_s & $\begin{array}{l}\text { Recharge rate to the surficial sand aquifer in } \\
\text { non-urban and non-wetland areas }\end{array}$ & Recharge & $7.92 \mathrm{in} / \mathrm{yr}$ & Yes & $8.7 \mathrm{in} / \mathrm{yr}$. \\
\hline rsimp_u & $\begin{array}{l}\text { Recharge rate to the surficial sand aquifer in } \\
\text { urban areas }\end{array}$ & Recharge & $-1.01 \mathrm{in} / \mathrm{yr}$ & - & No change \\
\hline rsimp_w & $\begin{array}{l}\text { Recharge rate to the surficial sand aquifer in } \\
\text { wetland areas }\end{array}$ & Recharge & $5.61 \mathrm{in} / \mathrm{yr}$ & Yes & $9.923 \mathrm{in} / \mathrm{yr}$. \\
\hline kriv & $\begin{array}{l}\text { Vertical hydraulic conductivity of the } \\
\text { streambed for Little Calumet River }\end{array}$ & River & $17.6 \mathrm{ft} / \mathrm{d}$ & - & No change \\
\hline
\end{tabular}


Table 14. Measured and model-calculated water levels and discharge measurements and modeled residuals for the March 2011 simulation.

\begin{tabular}{|c|c|c|c|c|}
\hline Observation name & Model layer & Observed value & Simulated value & Residual \\
\hline \multicolumn{5}{|c|}{ Water level, in feet above NAVD 88} \\
\hline IM-7 & 2 & 603.31 & 604.37 & -1.06006 \\
\hline IM-4S & 2 & 604.62 & 603.909 & 0.710876 \\
\hline IM-4D & 3 & 604.53 & 603.903 & 0.627136 \\
\hline IM-2 & 2 & 602.43 & 602.417 & $1.31 \mathrm{E}-02$ \\
\hline M-5 & 2 & 602.76 & 603.438 & -0.677795 \\
\hline $\mathrm{W}-10$ & 2 & 602.39 & 602.677 & -0.287231 \\
\hline E-3 & 2 & 602.94 & 602.858 & $8.18 \mathrm{E}-02$ \\
\hline W-11 & 2 & 591.57 & 589.754 & 1.81561 \\
\hline M-1 & 2 & 591.25 & 591.666 & -0.41571 \\
\hline E-2 & 2 & 593.45 & 594.418 & -0.968018 \\
\hline W-9 & 2 & 597.14 & 597.995 & -0.854675 \\
\hline 232 & 2 & 584.14 & 584.309 & -0.169189 \\
\hline BH-17 & 2 & 587.58 & 585.599 & 1.98059 \\
\hline $\mathrm{W}-1 \mathrm{~A}$ & 2 & 604.25 & 603.298 & 0.951904 \\
\hline W-5 & 2 & 604.28 & 604.413 & -0.133057 \\
\hline W-2 & 2 & 605.19 & 604.599 & 0.591125 \\
\hline W-3DUNE & 2 & 603.73 & 603.474 & 0.256348 \\
\hline W-4 & 2 & 607.48 & 605.039 & 2.44086 \\
\hline M-6 & 2 & 603.87 & 603.294 & 0.5755 \\
\hline IM-3S & 2 & 602.35 & 602.433 & $-8.35 \mathrm{E}-02$ \\
\hline IM-3D & 3 & 602.45 & 602.435 & $1.53 \mathrm{E}-02$ \\
\hline IUN-2 & 2 & 600.53 & 599.584 & 0.945679 \\
\hline IUN-3 & 2 & 597.04 & 596.45 & 0.590393 \\
\hline IUN-4 & 2 & 593.24 & 593.292 & $-5.20 \mathrm{E}-02$ \\
\hline IUN-6 & 2 & 600.77 & 599.374 & 1.39612 \\
\hline IUN-9 & 2 & 595.56 & 595.635 & $-7.48 \mathrm{E}-02$ \\
\hline W-7C & 2 & 602.35 & 601.817 & 0.533203 \\
\hline E-8 & 2 & 602.5 & 602.047 & 0.453003 \\
\hline W-6 & 2 & 602.3 & 602.619 & -0.319214 \\
\hline E-5 & 2 & 604.05 & 604.093 & $-4.35 \mathrm{E}-02$ \\
\hline \multicolumn{5}{|c|}{ Discharge, in cubic feet per second } \\
\hline US-12 ditch & (Not applicable) & -0.878 & -0.585369 & -0.292631 \\
\hline $\begin{array}{l}\text { County Line } \\
\text { Road ditch }\end{array}$ & (Not applicable) & -0.1 & $-8.61 \mathrm{E}-02$ & $-1.39 \mathrm{E}-02$ \\
\hline
\end{tabular}




\section{Model Fit to Observations}

The unweighted water-level residuals are shown aerially in figure 30 for the wet-weather simulation. The mix of positive and negative residuals in different parts of the model area is a characteristic of an adequately calibrated model.

Computed statistics based on the unweighted water-level residuals are presented in table 15. The range of unweighted water-level residuals can be expressed by their standard deviation, which is $0.84 \mathrm{ft}$. Seventy percent of the residuals are within 1 standard deviation of the mean residual, and 90 percent are within 2 standard deviations. The magnitude of water-level residuals can be represented by the mean absolute error, which is $0.64 \mathrm{ft}$. The relative accuracy of the model calibration can be measured by the percent mean absolute error, which is the mean absolute error divided by the overall range in water levels. The percent mean absolute error for the model is 3.07 percent. Two flow observations were considered appropriate to be used in this simulation: one is flow in the ditch along US-12 and the other is flow in County Line Road ditch. The measured flow from US-12 ditch in March 2011 was $0.878 \mathrm{ft}^{3} / \mathrm{s}$, and the simulated flow was $0.585 \mathrm{ft}^{3} / \mathrm{s}$. The measured flow along County Line Road ditch in March 2011 was $0.1 \mathrm{ft}^{3} / \mathrm{s}$, and the simulated flow was $0.09 \mathrm{ft}^{3} / \mathrm{s}$.

Because this is a scenario simulating a wetter hydrologic condition based on the calibrated October 2002 model, a weighted residual analysis was deemed unnecessary. Unweighted residuals of observations collected in March 2011 were used in the adjustment of recharge parameters and to calculate statistics that are presented in table 15. On the basis of higher, but relatively similar unweighted residual statistics such as the percent mean absolute error (2.96 percent for dry weather, 3.07 percent for wet weather), the wet-weather simulation adequately represents the observed conditions.

Table 15. Computed statistics based on the unweighted water-level residuals for the wet-weather (March 2011) hydrologic condition.

[ft, feet; $\mathrm{ft}^{3} / \mathrm{s}$, cubic feet per second]

\begin{tabular}{|c|c|c|c|c|c|c|c|}
\hline \multirow[b]{2}{*}{$\begin{array}{l}\text { Type of } \\
\text { residual }\end{array}$} & \multicolumn{7}{|c|}{ Statistics based on unweighted model residuals } \\
\hline & $\begin{array}{l}\text { Minimum } \\
\text { residual } \\
\text { (ft) }\end{array}$ & $\begin{array}{l}\text { Mean } \\
\text { residual } \\
\text { (ft) }\end{array}$ & $\begin{array}{l}\text { Maximum } \\
\text { residual } \\
\text { (ft) }\end{array}$ & $\begin{array}{c}\text { Standard } \\
\text { deviation of } \\
\text { the residuals } \\
\text { (ft) }\end{array}$ & $\begin{array}{c}\text { Bias } \\
\text { (ft) }\end{array}$ & $\begin{array}{l}\text { Mean } \\
\text { absolute } \\
\text { error } \\
\text { (ft) }\end{array}$ & $\begin{array}{c}\text { Percent } \\
\text { mean } \\
\text { absolute } \\
\text { error }\end{array}$ \\
\hline Water level & -1.06 & 0.29 & 2.44 & 0.84 & 8.84 & 0.64 & 3.07 \\
\hline $\begin{array}{l}\text { Type of } \\
\text { residual }\end{array}$ & $\begin{array}{c}\text { Drainage } \\
\text { feature name }\end{array}$ & $\begin{array}{c}\text { Observed } \\
\left(\mathrm{ft}^{3} / \mathrm{s}\right)\end{array}$ & $\begin{array}{c}\text { Simulated } \\
\left(\mathrm{ft}^{3} / \mathrm{s}\right)\end{array}$ & $\begin{array}{c}\text { Residual } \\
\left(\mathrm{ft}^{3} / \mathrm{s}\right)\end{array}$ & & & \\
\hline Streamflow & US-12 ditch & -0.88 & -0.59 & -0.29 & & & \\
\hline Streamflow & $\begin{array}{l}\text { County Line } \\
\text { Road ditch }\end{array}$ & -0.10 & -0.09 & -0.01 & & & \\
\hline
\end{tabular}




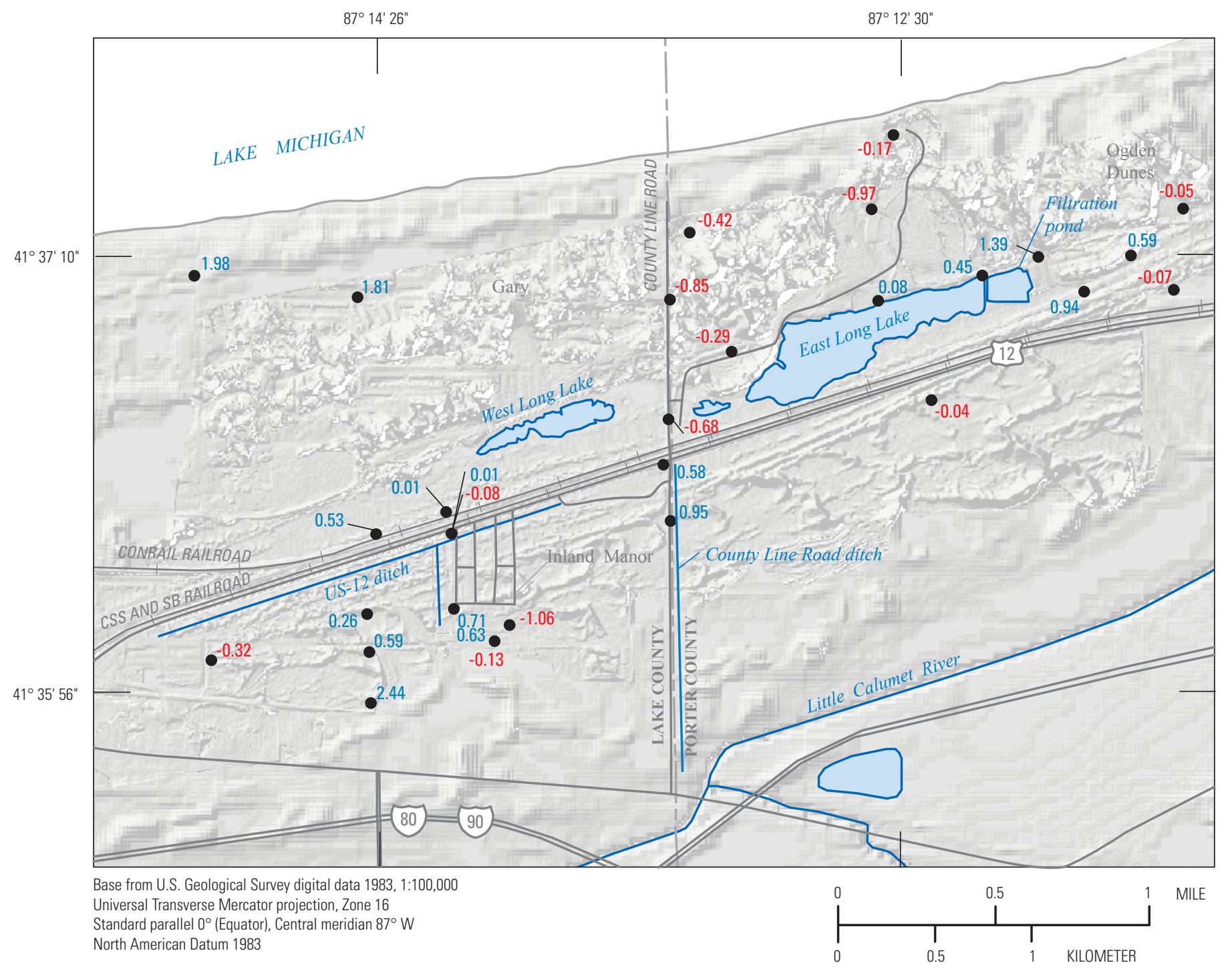

EXPLANATION

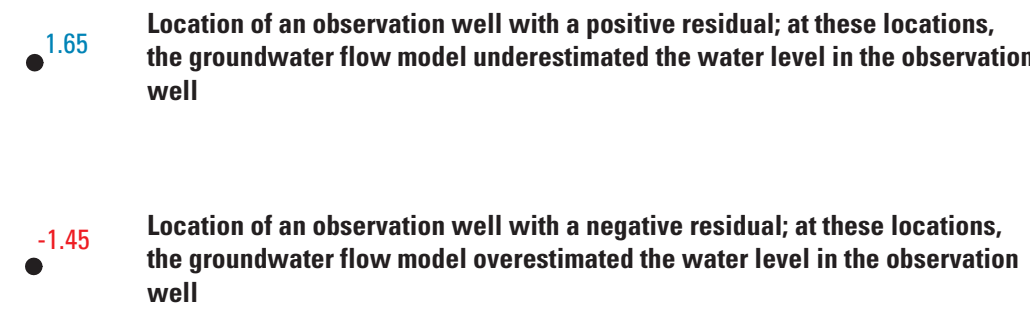

Figure 30. Differences between observed and simulated water levels for the wet-weather (March 2011) simulation of the area near Long Lake, Indiana Dunes National Lakeshore, Indiana. 


\section{Simulated Water Budget}

The results of the calibrated model can be quantified and analyzed by an overall water budget and by a budget for individual parts of the flow system. Table 16 lists the overall budget for the model simulating the wet-weather conditions of March 2011. A large proportion of the discharge from the model (46 percent) goes to the Little Calumet River rather than to Lake Michigan, similar to results from the October 2002 calibrated model. If flow to the Grand Calumet lagoons were included with streamflow, then the percentage of flow to streams would increase. Twelve percent of the discharge from the model goes to the ditches (drains) simulated in the model.

The budget between the model and the three water bodies - East Long Lake, West Long Lake, and the filtration pond - was analyzed, and the results are shown in figure 31 . Less than 5 percent of the water entering the aquifer is directly from these water bodies, and as opposed to the calibrated October 2002 model results, most of that water is from East Long Lake and not the filtration pond. Another difference between the calibrated dry-weather model and the simulated wet-weather condition is the flow interaction between East Long Lake and the filtration pond. In the dry-weather simulation, water enters East Long Lake from the filtration pond. The opposite occurs in the wet-weather (March 2011) simulation: a small amount of water (approximately 4 percent of all water leaving East Long Lake, but 21 percent of all water entering the filtration pond) is flowing from East Long Lake to the filtration pond. Both of these conditions are likely due to the discontinued use of the filtration pond in 2009. The major sources of water to East Long Lake in the wet-weather simulation are precipitation ( 46 percent of total) and inflow from the surficial aquifer (54 percent of total).

Table 16. Water budget associated with the wet-weather (March 2011) simulation.

$\left[\mathrm{ft}^{3} / \mathrm{s}\right.$, cubic feet per second; \%, percent]

\begin{tabular}{|c|c|c|c|c|c|}
\hline \multirow{2}{*}{$\begin{array}{l}\text { Inflow to model } \\
\text { Lake Michigan and Grand Calumet } \\
\text { Lagoons (Constant-head boundaries) }\end{array}$} & \multicolumn{2}{|c|}{$\begin{array}{c}\text { Inflow rate }\left(\mathrm{ft}^{3} / \mathrm{s}\right) \text { and } \\
\text { percent of total }\end{array}$} & \multirow{2}{*}{$\begin{array}{c}\text { Outflow from model } \\
\text { Lake Michigan and Grand Calumet } \\
\text { Lagoons (Constant-head boundaries) }\end{array}$} & \multicolumn{2}{|c|}{$\begin{array}{c}\text { Outflow rate }\left(\mathrm{ft}^{3} / \mathrm{s}\right) \text { and } \\
\text { percent of total }\end{array}$} \\
\hline & 0.40 & $(5.21 \%)$ & & 2.98 & $(38.52 \%)$ \\
\hline & & & $\begin{array}{l}\text { Leakage into US-12 ditch, County Line } \\
\text { Road ditch, Unnamed Tributary to } \\
\text { Little Calumet River (Model drains) }\end{array}$ & 0.96 & $(12.43 \%)$ \\
\hline Bedrock (Head-dependent boundary) & 0.03 & $(0.38 \%)$ & Bedrock (Head-dependent boundary) & 0.04 & $(0.49 \%)$ \\
\hline Precipitation (Recharge) & 7.31 & $(94.40 \%)$ & Leakage to sewers (Recharge) & 0.18 & $(2.33 \%)$ \\
\hline Total inflow & 7.74 & & Total outflow & 7.74 & \\
\hline
\end{tabular}




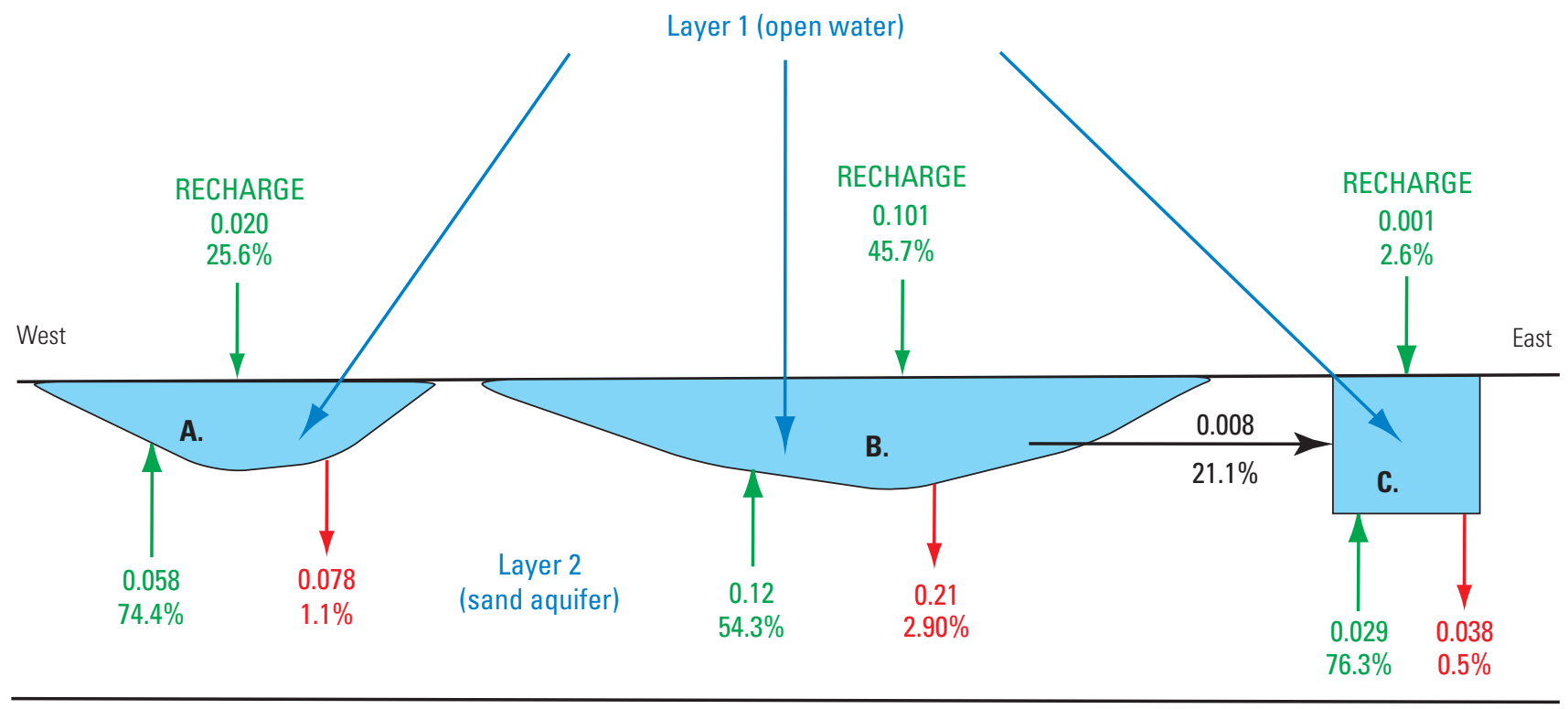

\section{EXPLANATION}

\section{A. West Long Lake \\ B. East Long Lake \\ C. Filtration pond}

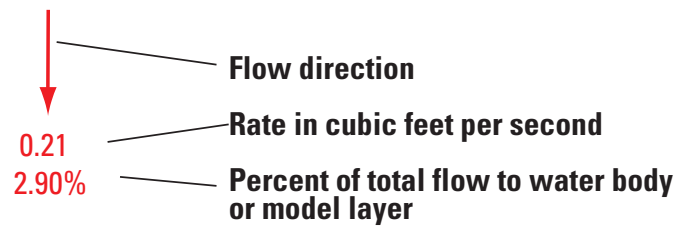

Figure 31. Flow interchange among the model and East Long Lake, West Long Lake, and the filtration pond for the wet-weather (March 2011) simulation.

\section{Simulated Water Levels and Groundwater Flow Paths}

Simulated water-level contours for the March 2011 simulation are shown in figure 32. As in the October 2002 simulated conditions, the major flow paths are a northern path to Lake Michigan and a southern path to the Little Calumet River. The groundwater divide that separates the two paths differs from that in the calibrated dry-weather model in that, east of County Line Road, the divide is simulated to be south of US-12. This agrees with the measured water-level contour map (fig. 13). Both the ditch along US-12 and County Line Road ditch affect the surface of the water table by draining water to the west toward the GSD sewer system and the Little Calumet River, respectively. County Line Road ditch bisects the groundwater divide and creates two water-table mounds south of US-12. The area of highest groundwater levels is to the south of US-12 ditch in a largely undeveloped area.

Backtracking flow paths were generated for the wetweather simulation in every node around the model perimeter and for nodes representing the US-12 ditch using MODPATH (Pollock, 2012); results are shown in figure 33. Flow paths are similar to those for the dry-weather calibrated model, extending north and south from the groundwater divides to Lake Michigan and the Little Calumet River, respectively. The area contributing water to US-12 ditch still does not include either East or West Long Lake. The majority of groundwater discharge to US-12 ditch comes from areas to the south and southwest of the ditch. Because the filtration pond is no longer active, groundwater flow paths that flow into the Little Calumet River to the east now originate further to the south and west of the filtration pond and East Long Lake. Much of the groundwater contribution to both East and West Long Lake originates from the areas near or south of US-12.

In figure 34, the vertical distribution of the flow lines is shown at two north-south cross sections, one along column 93 beneath US-12 ditch and the other along column 290 beneath East Long Lake (locations shown in fig. 17). For the cross section through US-12 (fig. 34A), flow lines are similar to those for the dry-weather calibrated model, showing the same pattern of mostly vertical flow near groundwater divides and discharging into the ditch. Some flow also discharges to the Little Calumet River to the south and Lake Michigan to the north. In figure $34 B$, the position of the groundwater divide has shifted further to the south compared to its position in the dry-weather calibrated model (fig. 28). More flow lines appear to discharge into East Long Lake, and flow beneath to ultimately discharge into Lake Michigan, than in the 2002 simulation. East and West Long Lakes still do not appear to capture water from as great an area as the ditch, but more so in the wetter 2011 condition than the 2002 drier condition. 


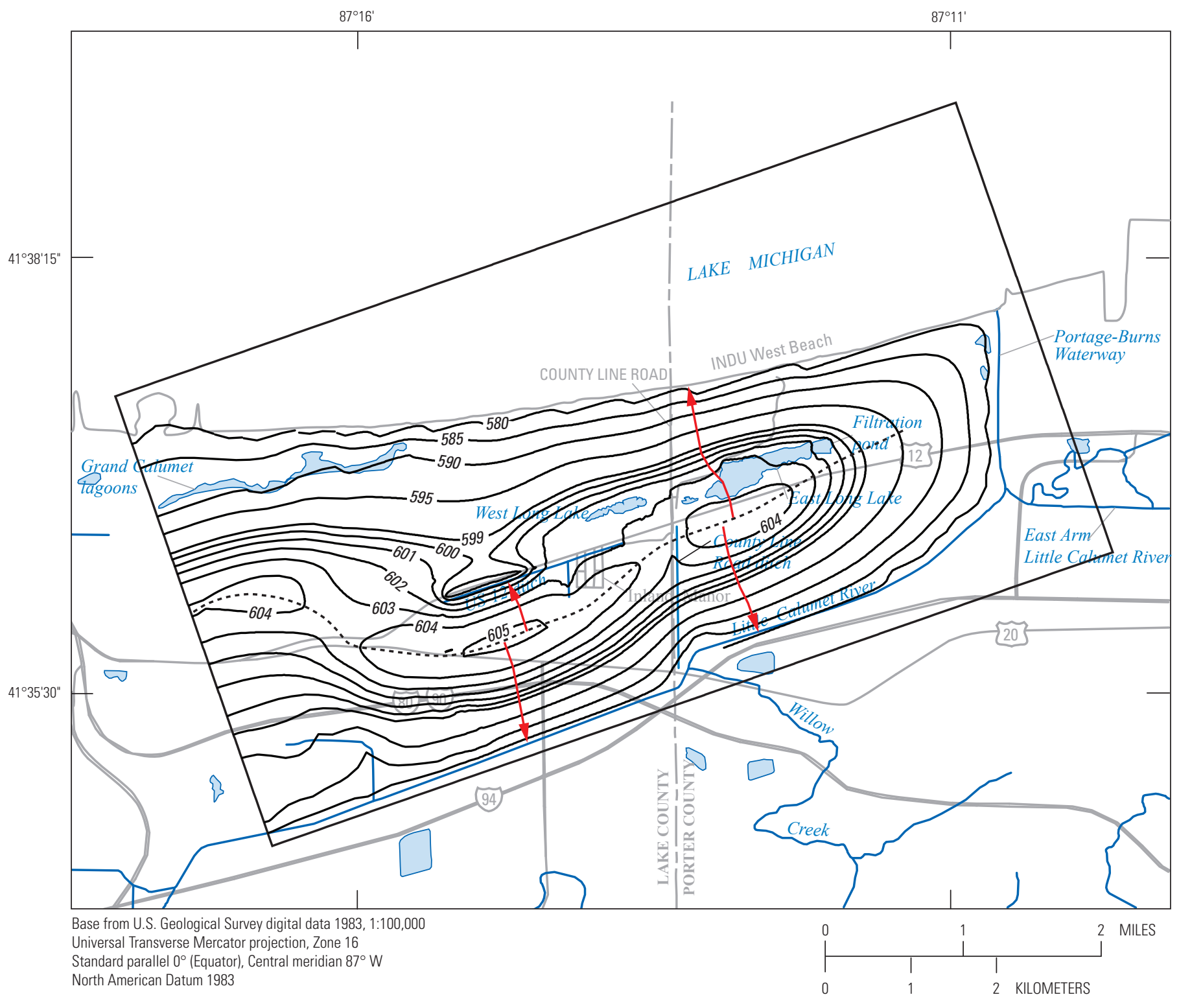

\section{EXPLANATION}

Simulated water-table contour-Shows the altitude of the water

$-601-$ table in feet above NAVD 88 simulated by the groundwater flow model in the surficial aquifer. Contour interval variable

\section{Arrow indicating direction of groundwater flow inferred from simulated} water-table contours

Groundwater divide—Approximate simulated divide in surficial aquifer, March 8, 2011

Figure 32. Simulated water-table contours from the wet-weather (March 2011) simulation. 


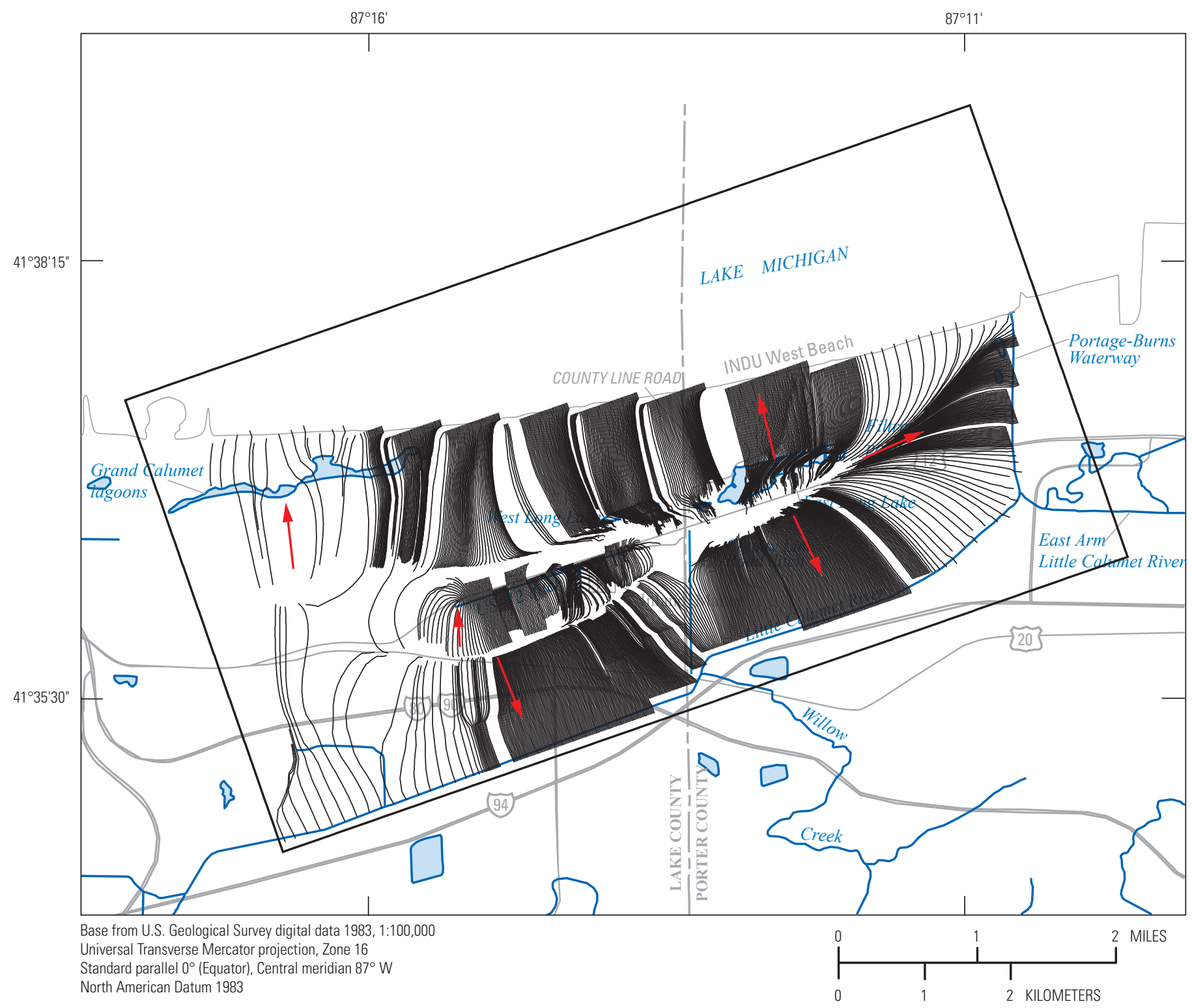

\section{EXPLANATION}

Horizontal groundwater flow path within the surficial sand aquifer.

Arrow indicating general direction of groundwater flow simulated by the wet-weather groundwater flow model

Figure 33. Flow lines representing simulated groundwater flow paths in the surficial aquifer under steady-state wet-weather conditions, March 2011. Arrows represent general directions of simulated groundwater flow. 


\section{A. Column 93}

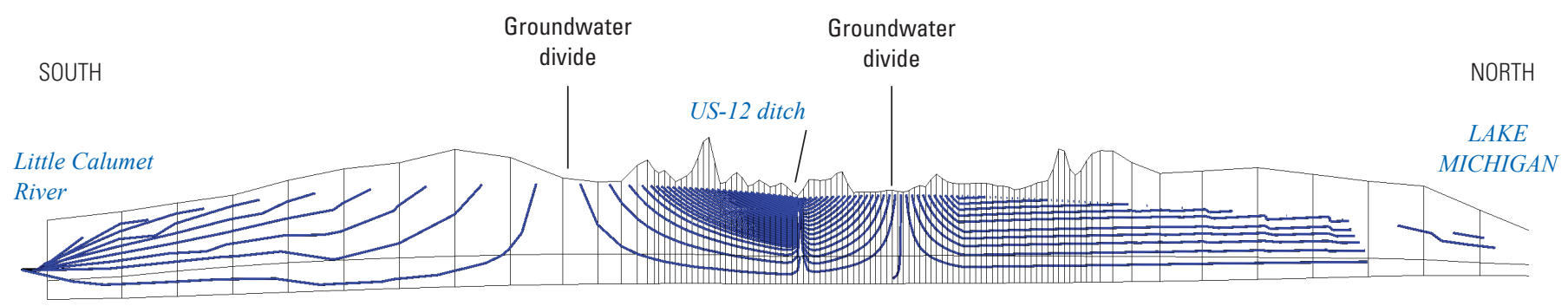

EXPLANATION

Groundwater flow path

B. Column 290

Groundwater

divide

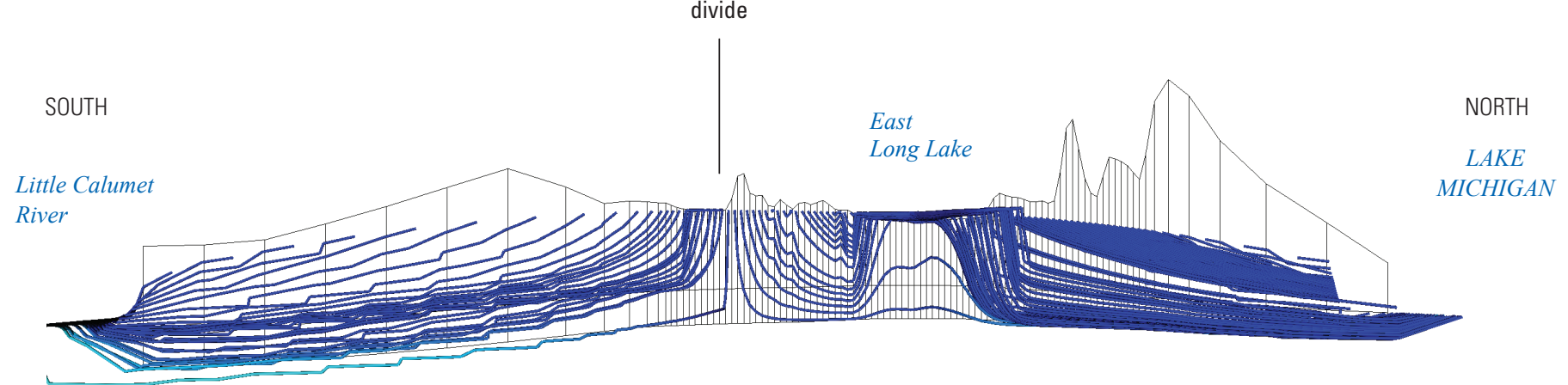

EXPLANATION

Groundwater flow path

Figure 34. Vertical flow paths simulated with the wet-weather (March 2011) simulation. $A$, Flow paths along column 93 and through the US-12 ditch. B, Flow paths along column 290 and through East Long Lake. 


\section{Simulated Inundated Areas}

Areas where the water table is simulated to be at or above the land surface are displayed in figure 35. Inundated areas were calculated by using the altitude of the simulated, steadystate water table and land-surface elevation as compiled from datasets with resolution of $98.4 \mathrm{ft}(30 \mathrm{~m})$ and $9.8 \mathrm{ft}(3 \mathrm{~m})$

(fig. 19). The digital land-surface altitude was subtracted from the water-table altitude to calculate the depth of the water table above the land surface. At the point where the water table rises above ground surface, surface runoff should be generated. Because of this, the actual area where water levels rise above land surface may be smaller than shown in figure 35, even though the amount of surface runoff is estimated to be small because of the high permeability of the materials at land surface. Inaccuracy in land-surface altitudes also adds to the uncertainty of the estimated area of inundation.
The distribution of inundated areas shown in figure 35 (compare with fig. 29) correlates with the observed field conditions during data collection on March 8, 2011. The water table in most areas to the north of US- 12 and surrounding West Long Lake is simulated to be above land surface. Some areas south of US-12 and west of County Line Road are simulated to be under water, but most flooded land surrounds US-12 ditch, Inland Manor, and wetlands just to the south of US-12. To the east of County Line Road, most flooded areas are north of US-12 in the areas including and surrounding East Long Lake. Minor areas of ponded water are also south of US-12 and East Long Lake. To the west of West Long Lake, the water table is simulated above the land surface in some small urban areas of Gary. The total area where the water table is above the land surface is much greater than the area from the calibrated dry-weather model. 


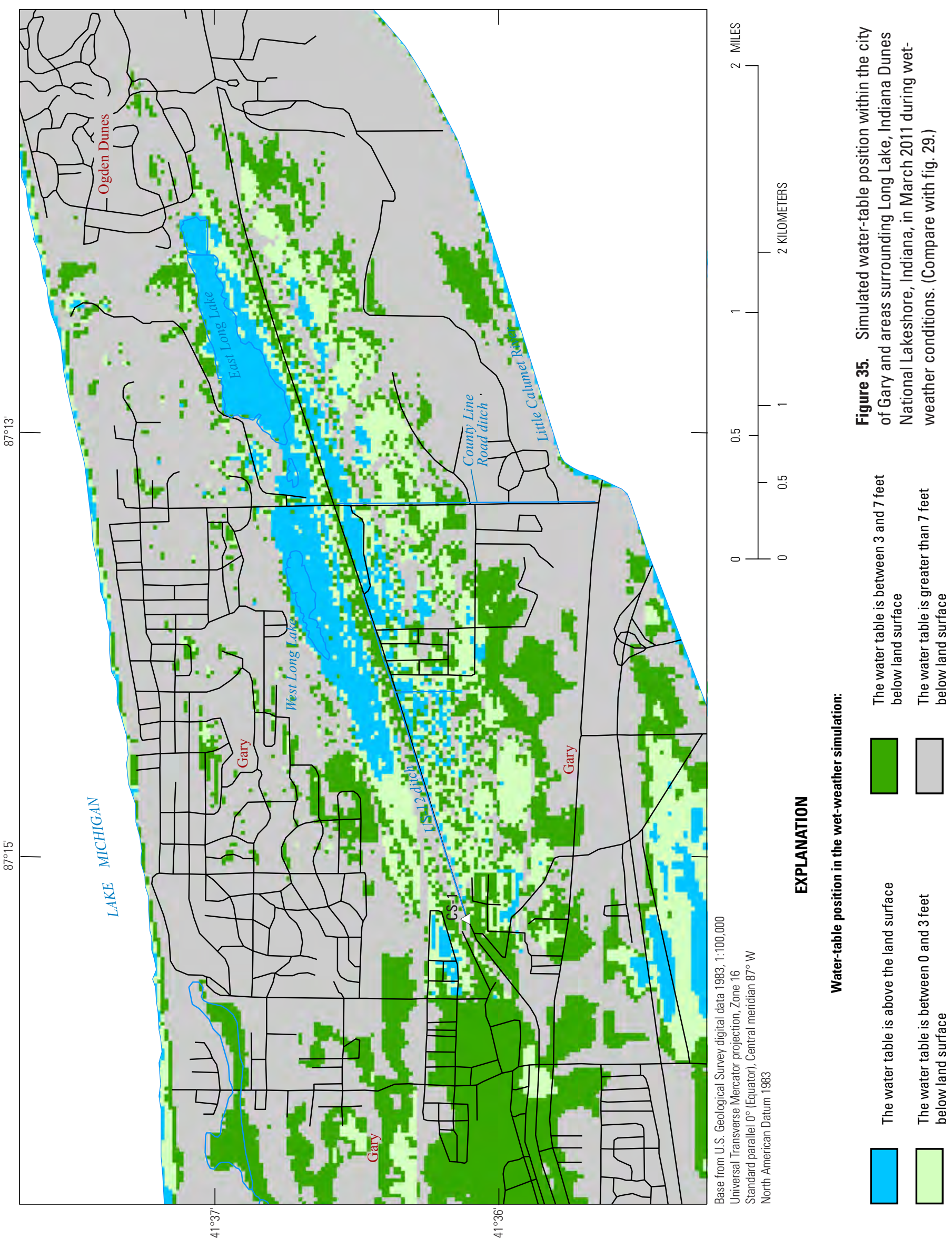




\section{Simulated Removal of Beaver Dams from US-12 Ditch}

Simulated removal of beaver dams from the US-12 ditch in the March 2011 simulation decreased the extent of inundated area near West Long Lake and the Inland Manor (fig. 36) and increased discharge to the US-12 ditch. Anecdotal accounts by former USGS staff relate that removal of beaver dams was a strategy employed by area residents in the early 21 st century to decrease water levels in the US-12 ditch and surrounding areas. During the March 2011 data-collection efforts, four beaver dams were located, and visual estimates of water-level differences between the upstream and downstream sides of the dams were made. Those estimates were included in the wet-weather groundwater flow simulation scenario. In order to estimate the impacts of the beaver dams on the wetweather condition observed in March 2011, a dam-removal scenario was simulated that uses the observed hydrologic conditions but with no dam effects applied to the US-12 ditch. The bottom elevation of the ditch in the dam scenario simulation was set to the elevation used in the calibrated dry-weather model. (No beaver dams were included in the dry-weather model.)

The simulated decrease in water level from the removal of the beaver dams affects the simulated inundated area in West Long Lake and west of County Line Road (fig. 36; compare with fig. 35). Compared to the wet-weather (March 2011) simulation (fig. 35), much less of the area west of County Line Road is estimated to be inundated in this scenario. Little to no effect of the dam removal on the water-table position can be seen in eastern parts of Gary or areas east of County Line Road. Simulated discharge from US-12 ditch increased 13 percent (about 50,000 gal/d) from the values simulated in the wet-weather (March 2011) simulation. 

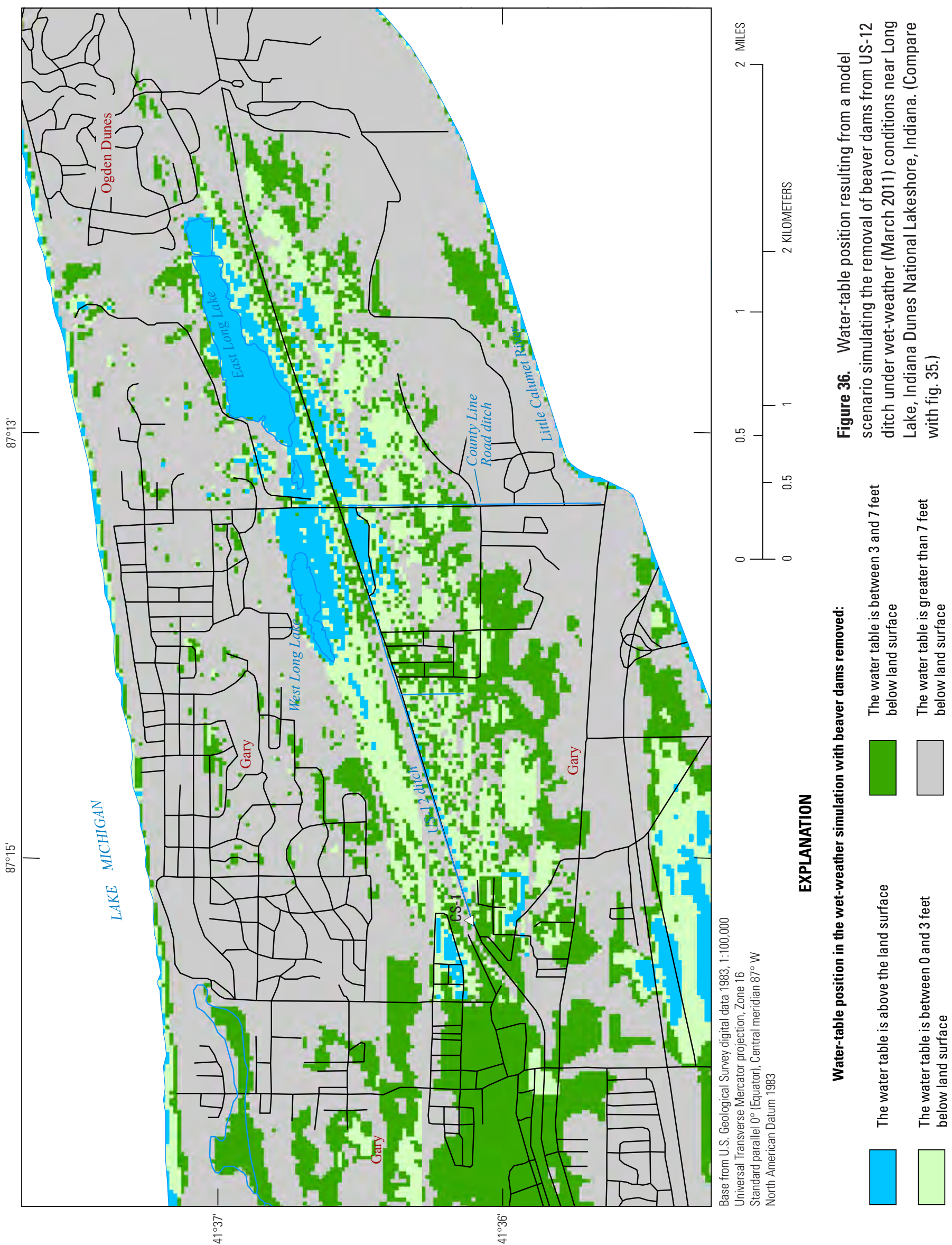


\section{Hydrologic Data and Groundwater Flow Simulations in the Vicinity of Long Lake, Indiana Dunes National Lakeshore}

\section{Simulated Discontinued Use of Water Treatment Plant Filtration Pond}

A simulated scenario with the October 2002 model in which use of the filtration pond was discontinued resulted in the transition of East Long Lake from a shallow lake to a wetland condition, with shallower water depths and a smaller overall inundated area. Because the filtration pond east of East Long Lake and west of Ogden Dunes was determined to contribute a large volume of water to the groundwater system and its use was discontinued in December 2009, a simulation was run to estimate potential effects of the discontinued use of the filtration pond on the calibrated dry-weather model (October 2002). Modifications to the model were made by setting the recharge parameter that represents the influx of water from the pond equal to zero. No other modifications were made to the groundwater model.

The removal of the influx of water from the filtration pond reduced areas simulated to be inundated by water in the dry-weather model, including areas near the filtration plant and much of East Long Lake (fig. 37; compare with fig. 29). The water table was estimated to be above the land surface in only very small areas of the filtration pond and localized areas of East Long Lake, the wetlands surrounding West Long Lake, and eastern Gary. Simulated discharge from US-12 ditch into the GSD sewer system decreased 2.4 percent (about $4,000 \mathrm{gal} / \mathrm{d}$ ) from the values simulated with the calibrated dryweather model. The prediction of East Long Lake's evolution toward a wetland condition during dry weather without inflow from the filtration pond may be an artifact of the "steady-state simulation" conditions of the model. Steady-state conditions require the assumption that recharge from precipitation and losses from evapotranspiration are constant; however, precipitation and snowmelt vary daily and seasonally, and evapotranspiration is lowest in the fall and winter months. East Long Lake is most likely to be inundated during dry-weather conditions after periods of snowmelt and precipitation, when evapotranspiration is least (that is, during late fall, winter, and early spring). The wetland condition is most likely during summer months as evapotranspiration depletes surface water and shallow groundwater.

The development of a wetland condition in East Long Lake without infiltration pond inflows is more likely during drier years with less precipitation, such as in 1952, 1956, 1958, 1962, and 2005 (Buszka and others, 2011, fig. 10). In those years, precipitation amounts were less than that in 2002. In addition, 1962-64 were three consecutive years with precipitation less than 30 in., the minimum for any set of three consecutive years in the 1952-2009 record.

Removal of the filtration-pond seepage did not affect the predicted extent of inundated area in West Long Lake or near Gary (fig. 37). Even though very few areas surrounding East and West Long Lake were estimated to be inundated by water, areas where water was estimated to be within $7 \mathrm{ft}$ of the land surface included parts of Gary, mostly low-lying areas south of the Grand Calumet lagoons and north of US-12, and wetland areas surrounding East and West Long Lake and south of US-12. 

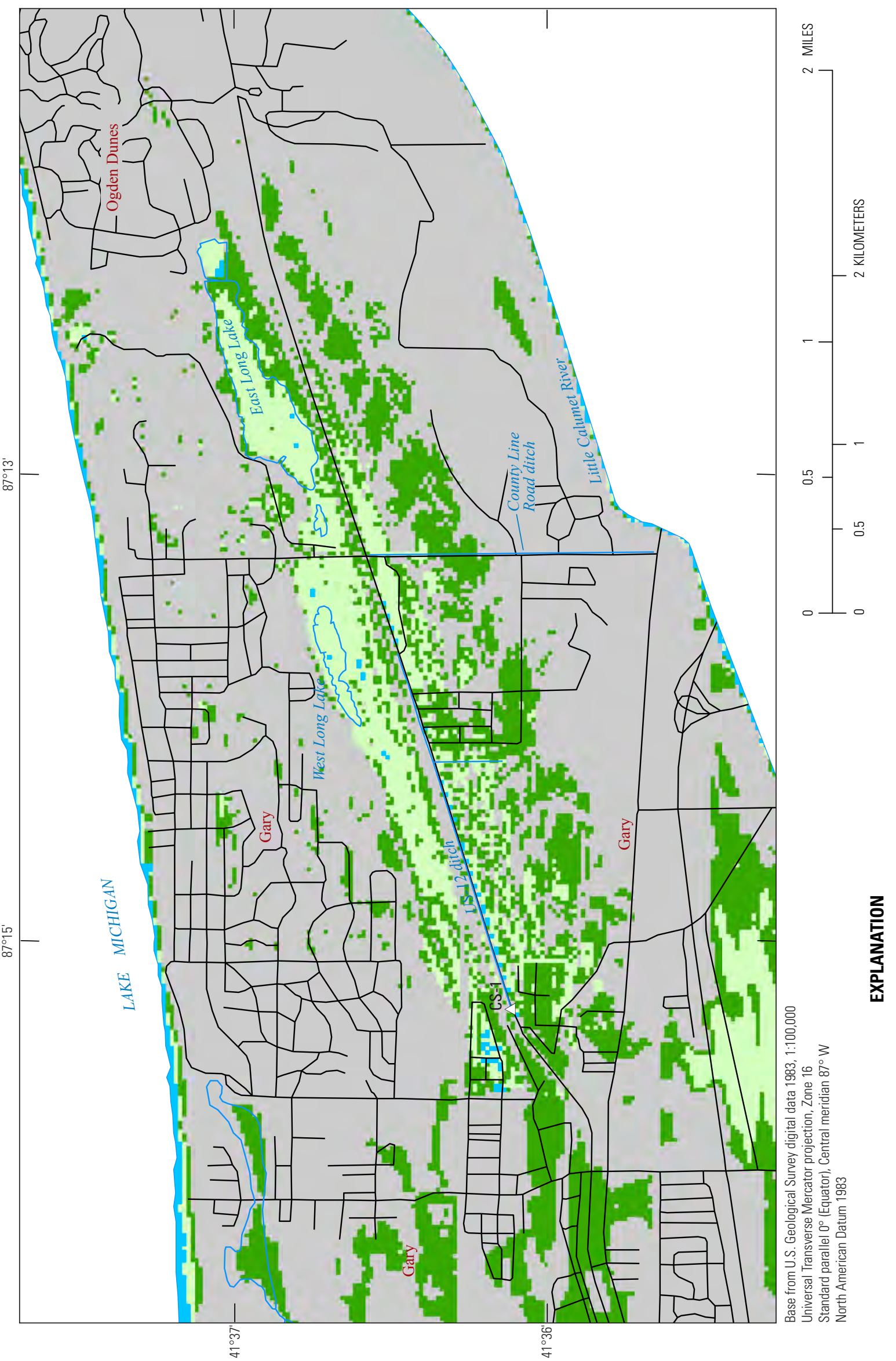

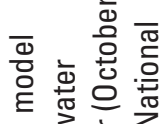

ช

돈 要

일

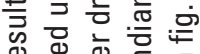

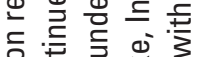

은 든

음 응 을 을

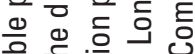

开

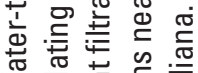

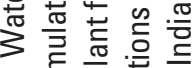

敦 응

ก่ 은 䒕

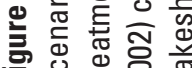

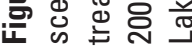

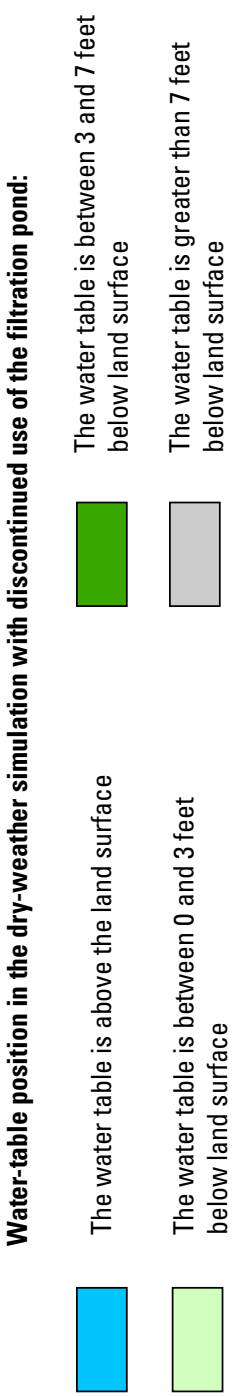




\section{Simulated Discontinuation of Discharge from US-12 Ditch}

Discontinuation of flow from the US-12 ditch to the GSD sewer system has been proposed to decrease the volume of untreated groundwater that enters the sewer and contributes to combined sewer overflows. Both the calibrated dry-weather (October 2002) groundwater flow model and wet-weather (March 2011) simulation were used to estimate the rise in the water-table surface caused by discontinuation of ditch discharge.

\section{Dry-Weather (October 2002) Simulation}

The removal of US-12 ditch from the dry-weather (October 2002) groundwater flow model greatly increased the area where the water table was estimated to be above the land surface beyond the inundated area simulated in the wetweather (March 2011) scenario (fig. 38; compare with figs. 29 and 35$)$. The increase in inundation predicted by the model is confined primarily to the west of County Line Road, where the total area estimated to be inundated by water is much greater than that presented in the dry-weather calibrated model. Much of the low-lying area north of US-12 and surrounding West
Long Lake, including residential areas in eastern Gary, was estimated to be inundated. To the south of US-12, the water table was estimated to be above the land surface in areas immediately surrounding US-12 ditch and in the interdunal areas south of the ditch.

\section{Wet-Weather (March 2011) Simulation}

The removal of US-12 ditch from the wet-weather simulation increased the amount of inundated area where the water table reaches the land surface throughout much of the modeled area (fig. 39; compare with fig. 35). To the east of County Line Road, the inundated area includes East Long Lake and the immediately surrounding wetland areas north of US-12, as well as low-lying interdunal areas south of US-12. Wetland areas immediately to the south of the filtration pond and East Long Lake also were estimated to be inundated. To the west of County Line Road, the water table is estimated to reach the land surface in extensive areas including West Long Lake, the surrounding wetlands, and residential areas of Gary. Large areas of Gary south of the Grand Calumet lagoons and north of US-12 are estimated to have groundwater levels within at least $7 \mathrm{ft}$ of the land surface - the approximate altitude of basements and other below-grade structures. 


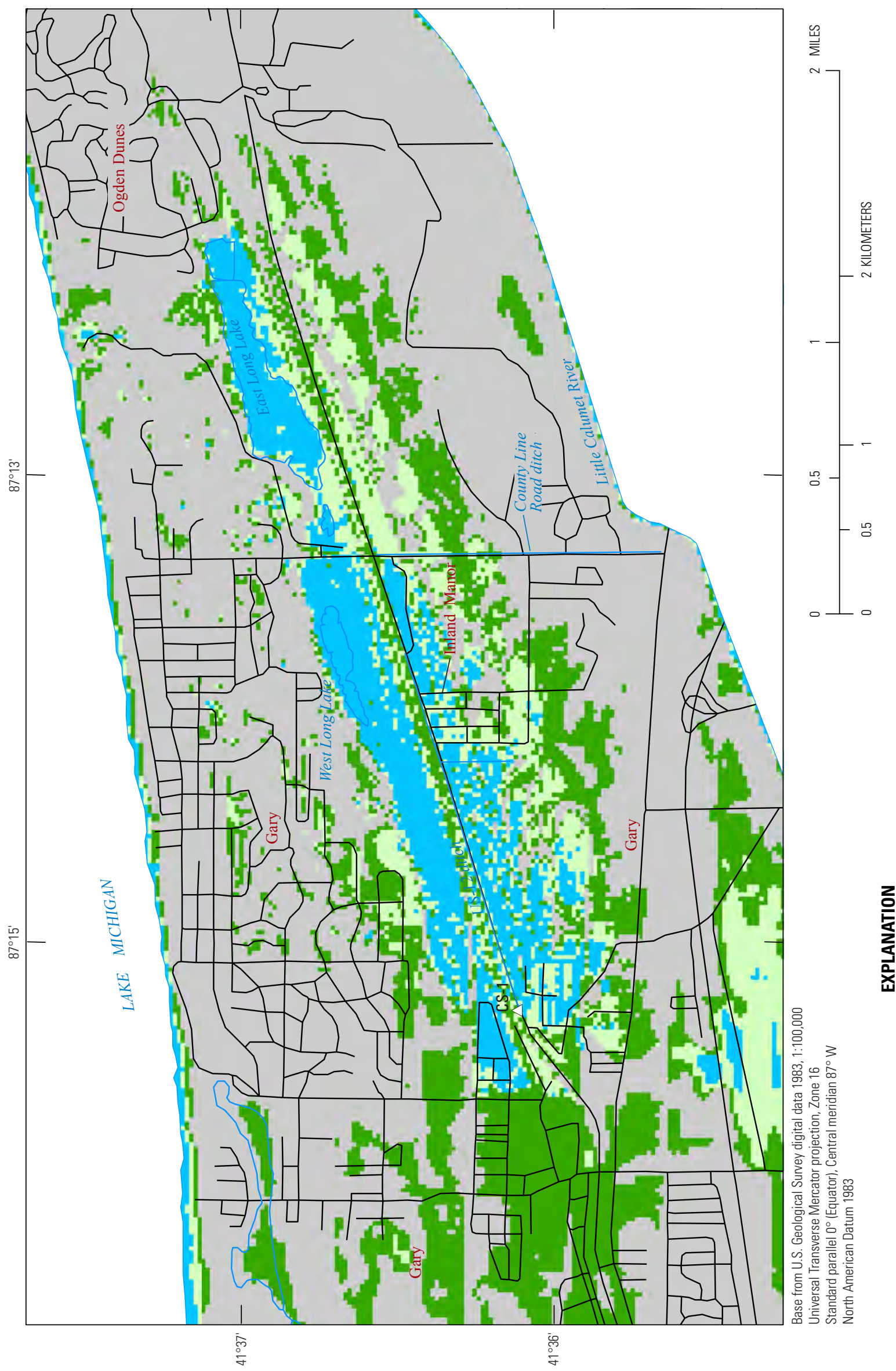

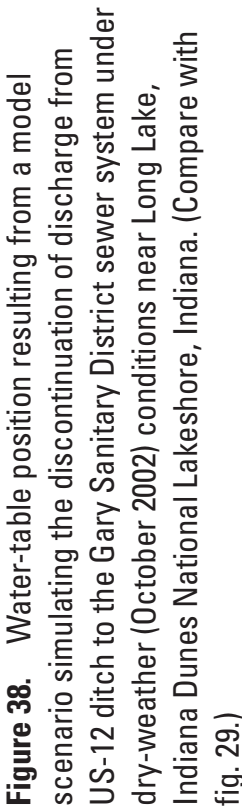

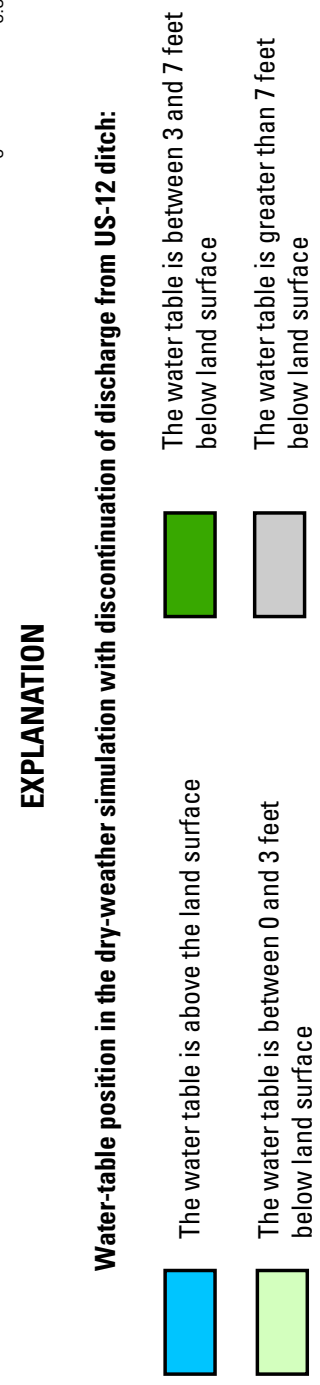



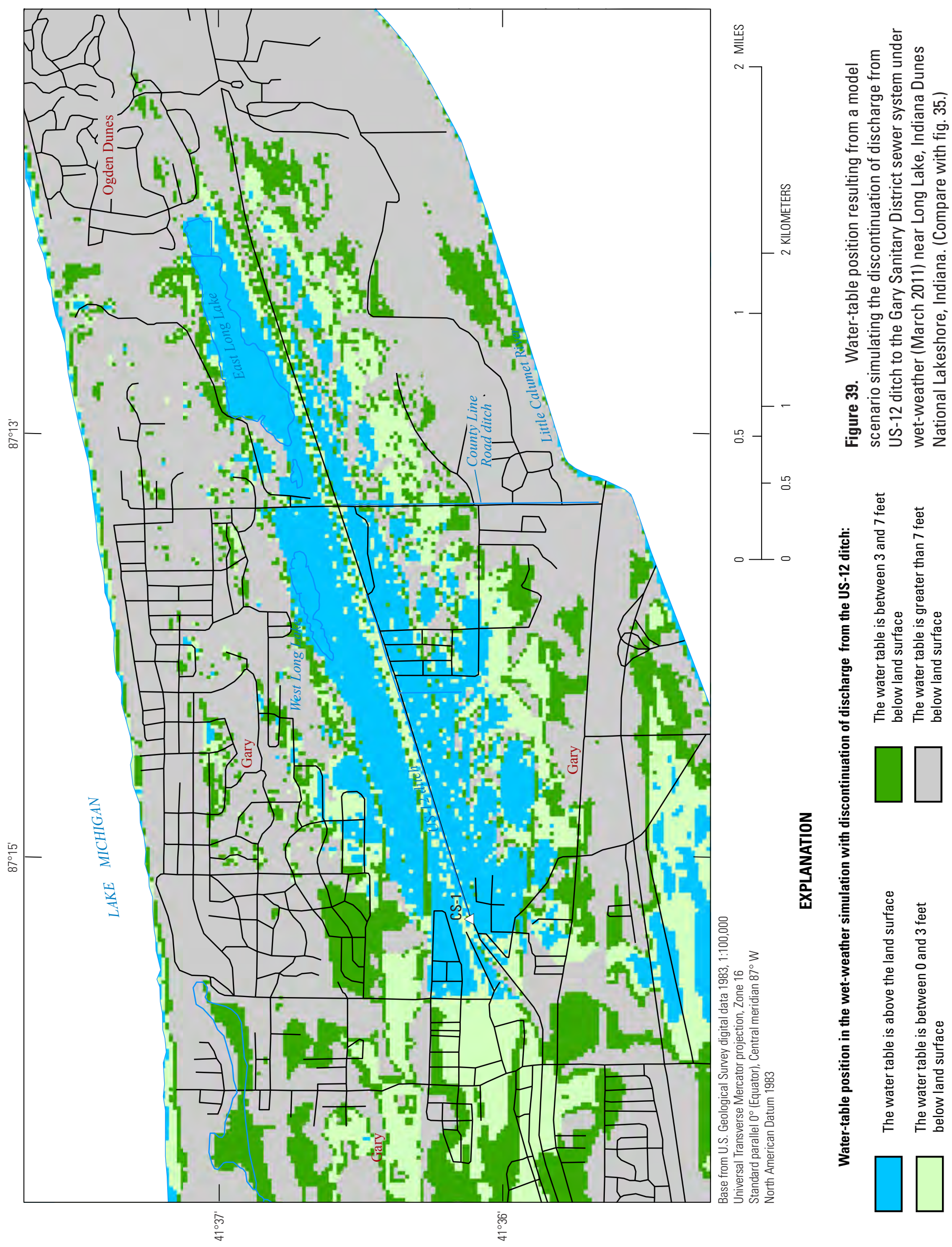


\section{Simulation of Decreased Discharge from Basin by US-12 Ditch}

As an alternative to closing the US-12 ditch, four different simulations that reduced flow out of the watershed from the ditch and into the GSD sewer system were completed. Two simulations used the results from the October 2002 model, but without the filtration pond, and two used results from the March 2011 simulation. Reductions in discharge were evaluated by simulating the increase in elevation of a weir plate at the control structure where discharge from the US-12 ditch enters the GSD sewer. These changes would effectively decrease the amount of water entering the sanitary sewer system but increase the amount of water pooling in US-12 ditch and retained in the adjacent surficial aquifer. The elevation of the model drain cells that represent the US-12 ditch were increased by $2 \mathrm{ft}$ and $4 \mathrm{ft}$ in simulations using the dry-weather model and were increased by $1 \mathrm{ft}$ and $2 \mathrm{ft}$ in simulations using the wet-weather simulation.

\section{Dry-Weather (October 2002) Simulation}

For the scenarios simulating a 2- and 4-ft increase of the weir plate elevation, simulated discharge from US-12 ditch decreased by approximately 29 percent (about $0.08 \mathrm{ft}^{3} / \mathrm{s}$ or $52,000 \mathrm{gal} / \mathrm{d}$ ) and 62 percent (about $0.19 \mathrm{ft}^{3} / \mathrm{s}$ or $124,000 \mathrm{gal} / \mathrm{d}$ ), respectively. The areas where the water table is estimated to be above the land surface for the scenario simulating a 4-ft increase of the weir plate elevation, along with discontinued use of the filtration pond, are displayed in figure 40 (compare with fig. 37). Flooded areas are limited to areas of West Long Lake and surrounding wetlands, parts of Gary to the west of the West Long Lake area, localized areas in East Long Lake and the filtration pond, and interdunal areas in the southwest part of the modeled area. These areas make up a much larger total inundated area than those resulting from the scenario simulating the discontinued use of the filtration pond using the calibrated, dry-weather model. Parts of Gary, mostly in low-lying areas south of the Grand Calumet lagoons and north of US-12, and wetland areas surrounding East and West Long Lake and south of US-12 could have groundwater levels within at least $7 \mathrm{ft}$ of the land surface.

\section{Wet-Weather (March 2011) Simulation}

For the scenarios simulating a 1- and 2-ft increase of the weir plate elevation, simulated discharge from US-12 ditch was decreased by approximately 3 percent (about $0.02 \mathrm{ft}^{3} / \mathrm{s}$ or $12,000 \mathrm{gal} / \mathrm{d}$ ) and 6 percent (about $0.04 \mathrm{ft}^{3} / \mathrm{s}$ or $23,000 \mathrm{gal} / \mathrm{d}$ ), respectively. The areas where the water table is estimated to be above the land surface for the scenario simulating a $2-\mathrm{ft}$ increase of the weir plate elevation under wet-weather (March 2011) conditions are displayed figure 41 (compare with fig. 35). Inundated areas west of County Line Road include West Long Lake, the wetlands surrounding West Long Lake, wetlands south of US-12, parts of Gary west of the terminus of US-12 ditch at its entry to the GSD sewer, and interdunal wetlands in the southwest part of the modeled area. To the east of County Line Road, flooded areas include East Long Lake and the surrounding wetlands, and some smaller wetlands south of US-12. These areas are similar to those resulting from the wetweather simulation except near the western terminus of US-12 ditch. Portions of Gary, mostly in low-lying areas south of the Grand Calumet lagoons and north of US-12, and wetland areas surrounding East Long Lake and West Long Lake and south of US-12 are estimated to have groundwater levels within at least $7 \mathrm{ft}$ of the land surface. 

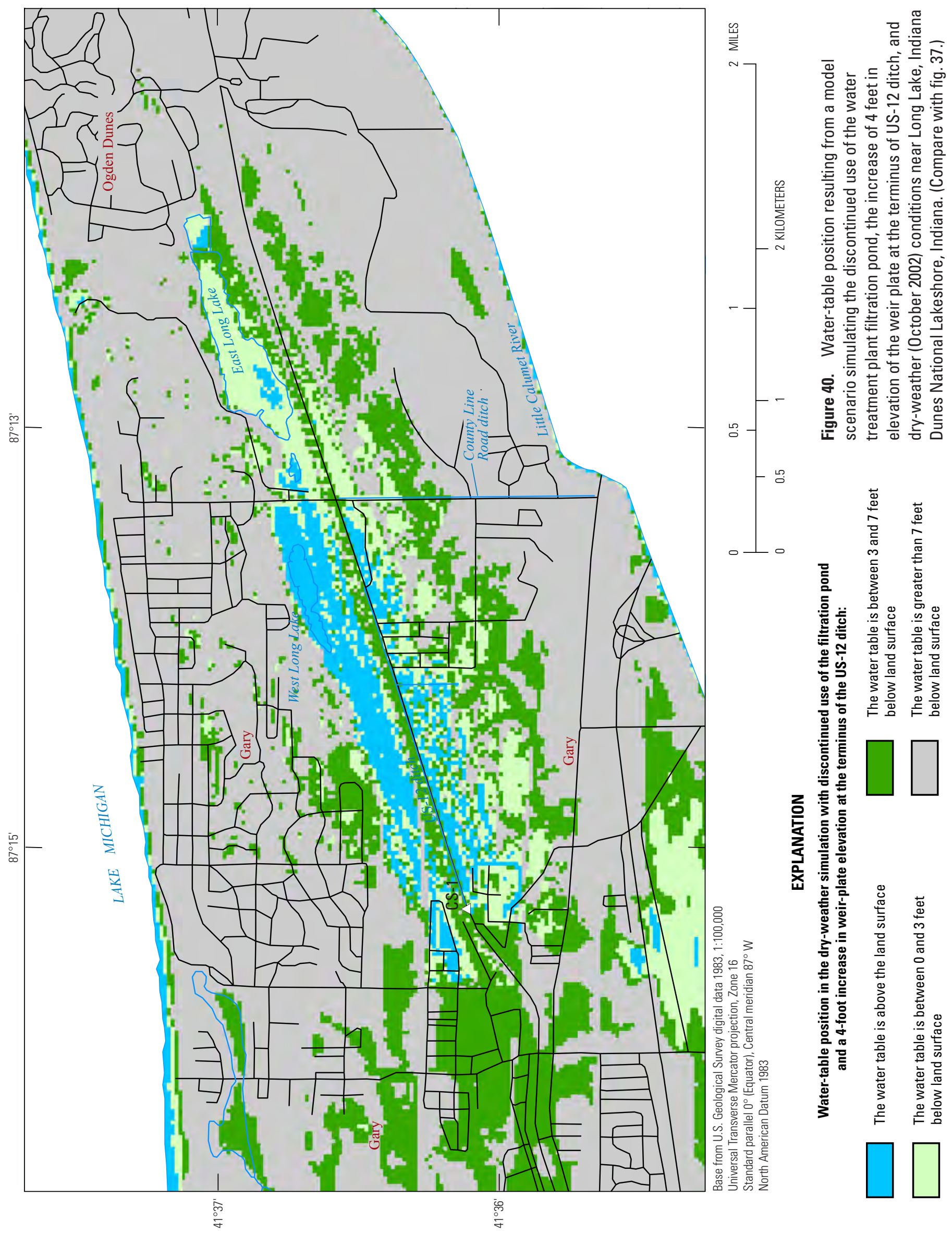


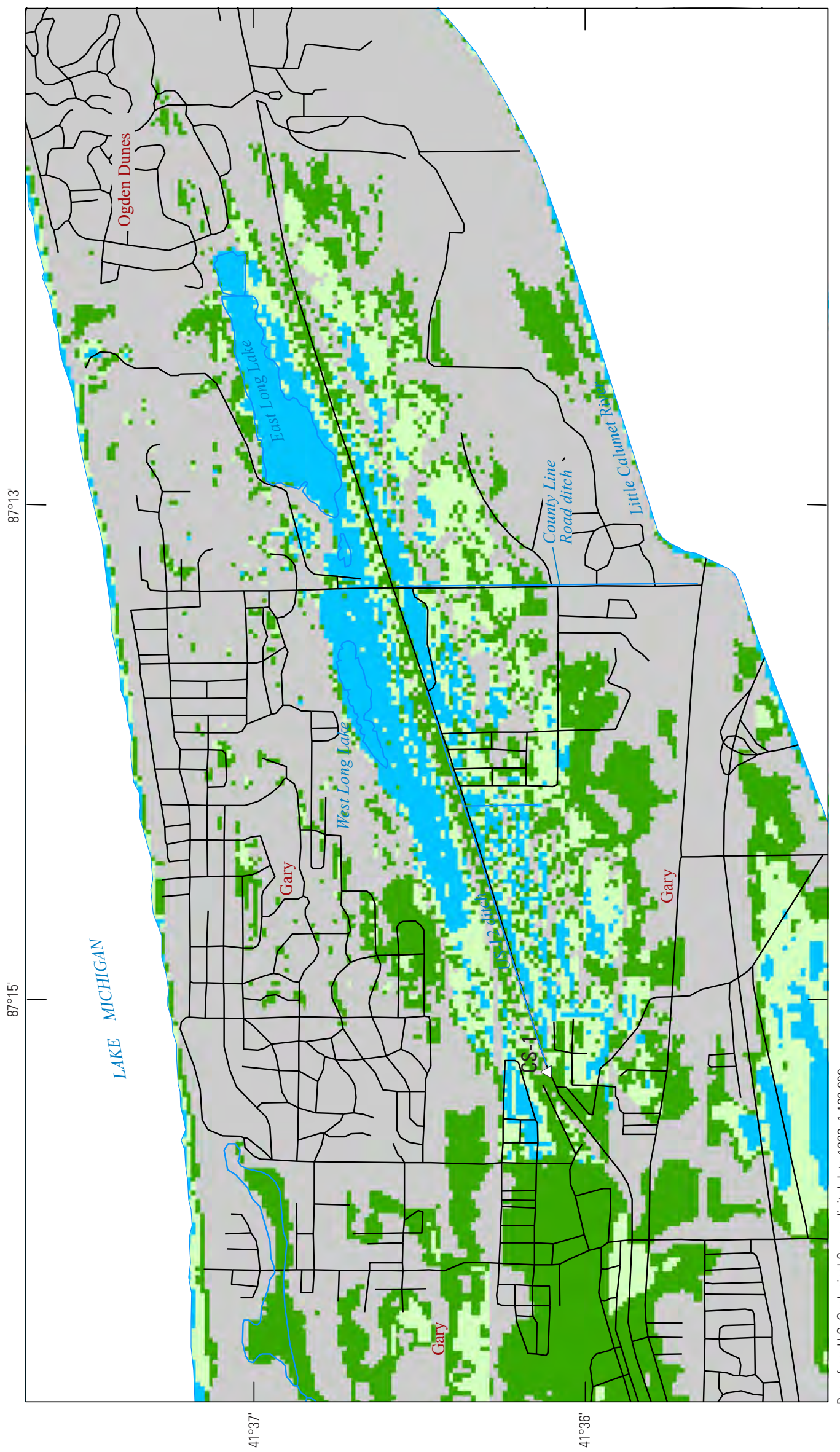




\section{Simulation of Hydraulic Connection between East and West Long Lake}

A hydraulic connection between East Long Lake and West Long Lake was simulated to understand how inundated areas would become distributed if a culvert under County Line Road were installed that directly connected East Long Lake to West Long Lake during a combination of wet-weather conditions and cessation of discharge from the US-12 ditch outside the watershed. To simulate the placement of a culvert between the open-water bodies of East Long Lake and West Long Lake, a hydrologic connection was estimated by activating the drain return package within MODFLOW-NWT (Banta, 2000). A single drain return cell was placed on the west side of County Line Road near West Long Lake and assigned a drain elevation of $0.1 \mathrm{ft}$ above the land surface within model layer 1 to ensure that the drain would only capture simulated surface water. The drain return package permits the return of captured water to the model in a user-specified model cell. Surface water captured by the drain on the west side of County Line Road was returned to approximately 1,500 ft east on the east side of County Line Road. This scenario was applied to the wet-weather condition simulation with US-12 ditch removed, the results of which generated small differences in the areas where the water table was above the land surface (fig. 42; compare with fig. 39). Local areas in Gary to the north and west of West Long Lake are simulated to no longer have the water table above the land surface because of the somewhat lower water table on the west side of County Line Road. Although the areas simulated to be flooded are similar to flooded areas in the wet-weather scenario simulating the cessation of discharge from US-12, it is expected that the depths of water west of County Line Road would be less in the simulation with the hydrologic connection between East Long Lake and West Long Lake. 

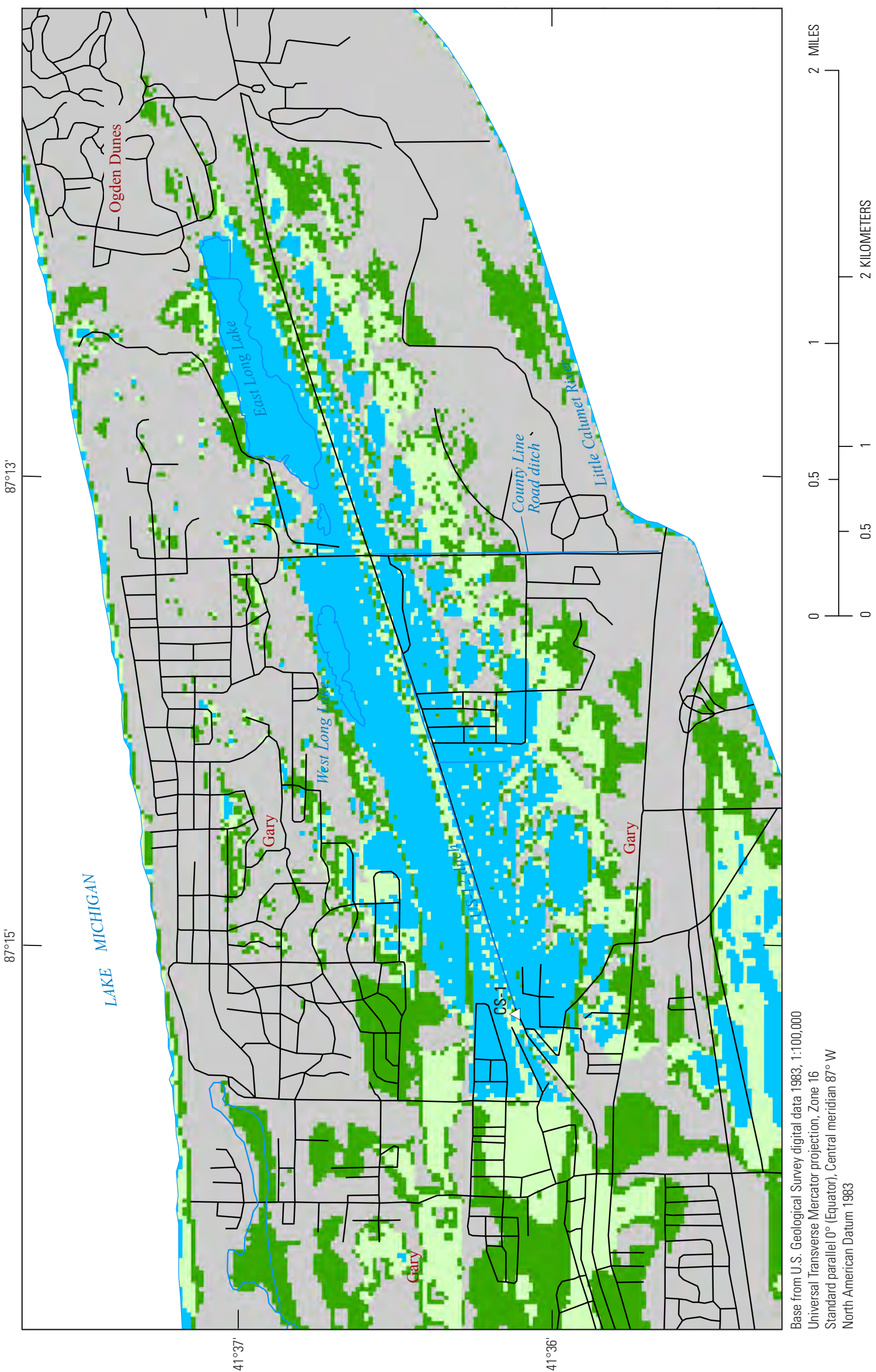

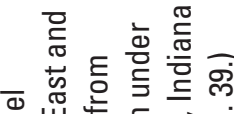

음 யँ

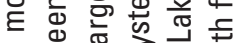

उ ट के ठำ

ธิ

든

.

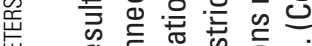

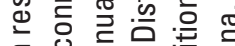

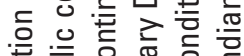

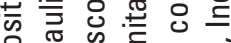
은 능 증

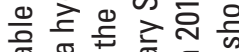
준 可

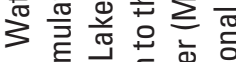

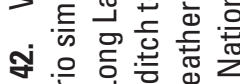

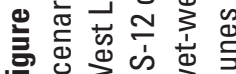

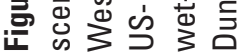

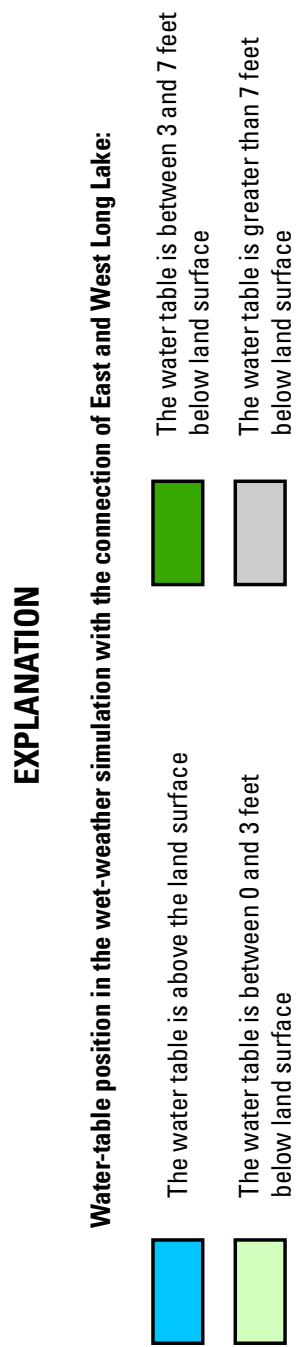




\section{Simulated Deepening of County Line Road Ditch}

The ditch on the east side of County Line Road extends from US-12 south and ultimately discharges to the Little Calumet River (fig. 3). The ditch routes surface water, plus groundwater that has seeped into the ditch, out of the basin. During the course of this investigation, it was determined that the gradient of the bottom of the ditch is not consistently toward the Little Calumet River (fig. 16), and the ditch can become obstructed by organic debris and discarded refuse that can hamper its ability to move water. A scenario was simulated that estimates the effects of applying a constant slope along County Line Road ditch from its northernmost point near US-12 to its discharge point at the Little Calumet River as opposed to the condition originally simulated that used the surveyed elevations in figure 16 . The bottom elevation of the ditch was estimated by using a constant slope between each of these points. The scenario was run for both the calibrated dryweather model and the wet-weather simulation.

\section{Dry-Weather (October 2002) Simulation}

Although the simulation of deepening of the County Line Road ditch did not affect the size of the areas where the water table was estimated to reach the land surface, the areas where the water table is within $7 \mathrm{ft}$ of the land surface were decreased in the area immediately surrounding the ditch just south of US-12 (fig. 43). Simulated discharge from US-12 ditch decreased 26 percent (about $0.08 \mathrm{ft}^{3} / \mathrm{s}$ or $52,000 \mathrm{gal} / \mathrm{d}$ ) from the values simulated in the calibrated dry-weather model. Simulated discharge from County Line Road ditch during the scenario was $0.320 \mathrm{ft}^{3} / \mathrm{s}(206,821 \mathrm{gal} / \mathrm{d})$, an increase of 100 percent from the values simulated in the calibrated October 2002 model.

\section{Wet-Weather (March 2011) Simulation}

Similar to the dry-weather simulation, the deepening of the ditch did not affect the size of the areas where the water table was estimated to reach the land surface; however, the places where the water table is within $7 \mathrm{ft}$ of the land surface were decreased in an area surrounding the ditch just south of US-12 (fig. 44). Unlike the dry-weather simulation results, the affected area includes parts of the wetland area surrounding East Long Lake, as well as a large part of the wetlands surrounding West Long Lake. This result indicates that the deepening of the ditch would likely remove water from them. Deepening of the County Line Road ditch also decreases the extent of flooded areas south and east of the filtration pond near Ogden Dunes when compared to the results that do not simulate a deepened ditch (fig. 35). Simulated discharge from US-12 ditch decreased 24 percent (about $0.14 \mathrm{ft}^{3} / \mathrm{s}$ or $92,000 \mathrm{gal} / \mathrm{d}$ ) from the values simulated in the wetweather (March 2011) simulation. Simulated discharge from County Line Road ditch during the scenario was $0.564 \mathrm{ft}^{3} / \mathrm{s}$ $(364,522 \mathrm{gal} / \mathrm{d})$, an increase of more than 500 percent from the values simulated without deepening the ditch. 

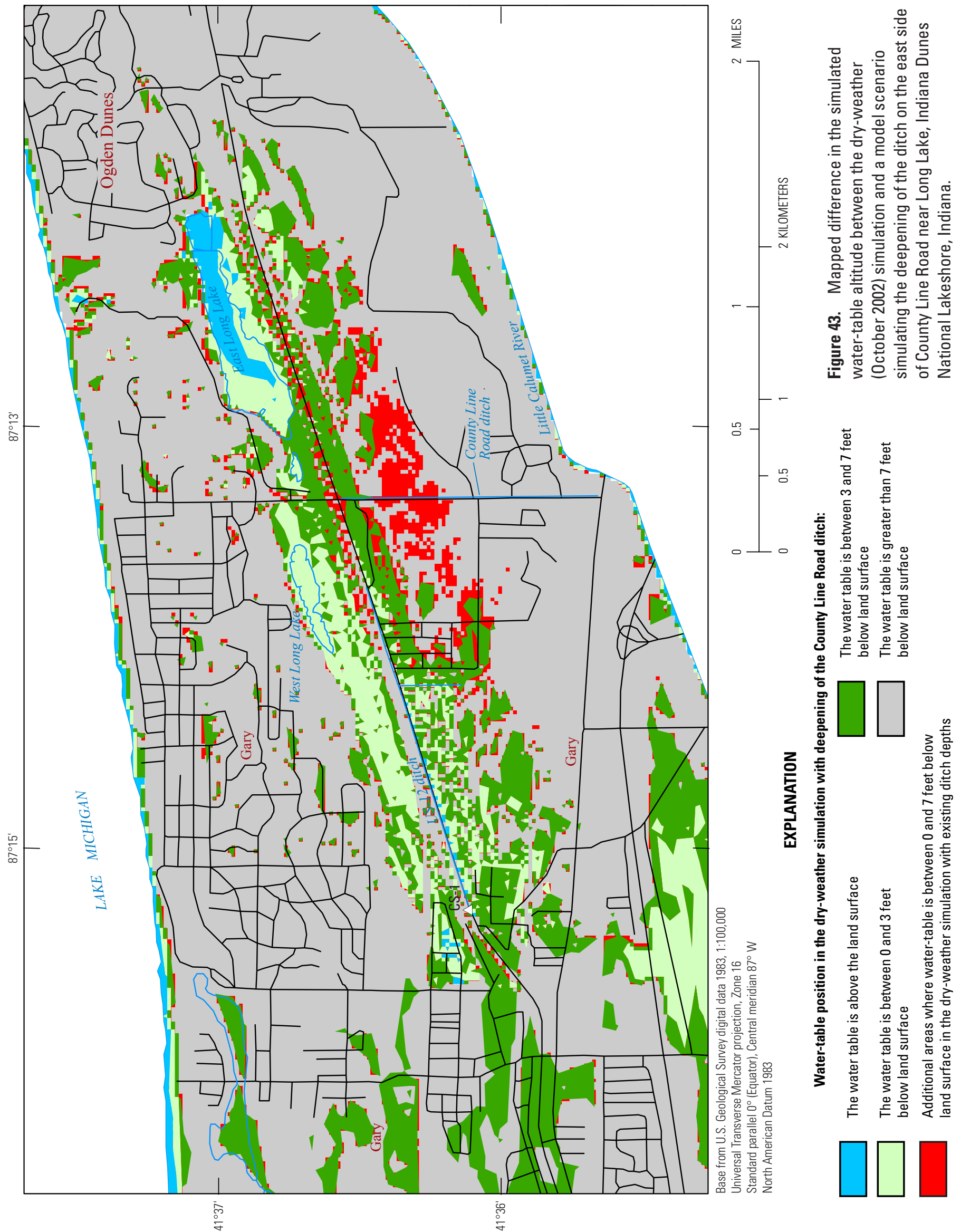

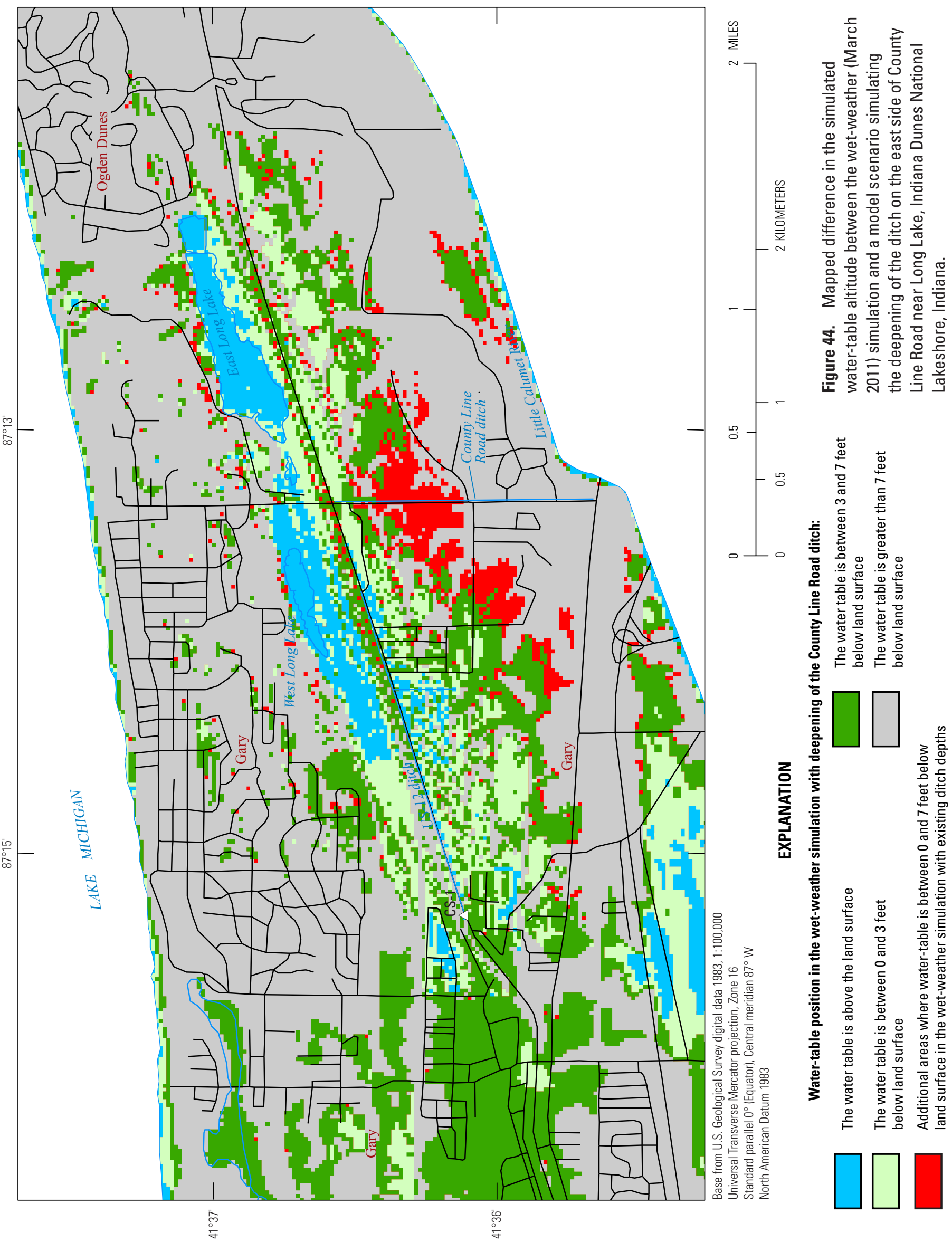

เ
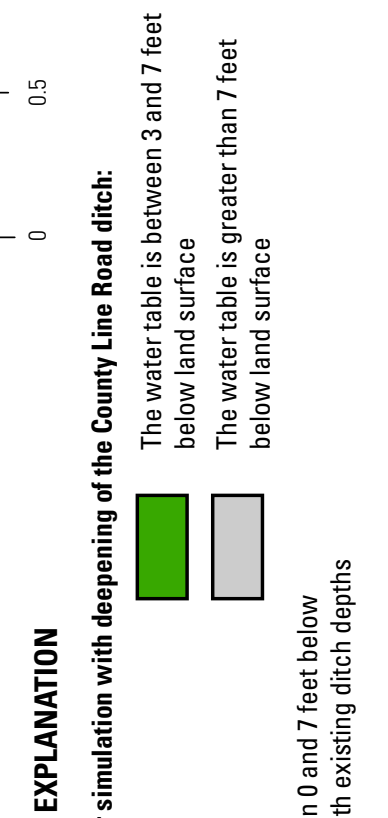


\section{Simulated Increase in Level of Lake Michigan}

A scenario simulating the increase in the level of Lake Michigan was run with both the calibrated dry-weather (October 2002) model and the wet-weather (March 2011) simulation to estimate the effects on simulated hydrology in the modeled area. In order to perform the simulation, the constant-head boundary condition that represents Lake Michigan along the northern part of the model (fig. 20) was set equal to the extreme high level of $583.86 \mathrm{ft}$ above NAVD 88 recorded on May 31, 1998, at the NOAA Lake Michigan monitoring site at Calumet Harbor, Ill. (period of record March 12, 1905, through September 8, 2011), an increase of $5.20 \mathrm{ft}$ for the October 2002 model and $6.16 \mathrm{ft}$ for the March 2011 simulation. No other parameter values or model input values were changed from those presented earlier in the report.

\section{Dry-Weather (October 2002) Simulation}

The increase of the level of Lake Michigan increased the size of the area where the water table is simulated to be above land surface (fig. 45; compare with fig. 29). Inundated areas east of County Line Road include East Long Lake, the filtration pond, the wetlands south of East Long Lake and North of US-12, and areas south of the filtration pond near Ogden Dunes. To the west of County Line Road, parts of West Long Lake and the wetlands to the east and south of West Long Lake are simulated to be flooded. Some residential areas in eastern Gary are also affected by the increase in Lake Michigan water level. The increase in water-table altitude in the western quarter of the model area that includes parts of Gary south of the Grand Calumet lagoons are most likely underestimated. This underestimation is due to the value of the constant-head boundary condition in the model that represents the Grand Calumet lagoons being set equal to the dry-weather observed conditions in October 2002, which are most likely lower than the lake level for May 31, 1998. No water-level data are available for the lagoons on May 31, 1998. Simulated discharge from US-12 ditch increased 14.2 percent (about $0.04 \mathrm{ft}^{3} / \mathrm{s}$ or $28,000 \mathrm{gal} / \mathrm{d}$ ) from the values simulated in the calibrated dry-weather (October 2002) model.

\section{Wet-Weather (March 2011) Simulation}

The increase of the level of Lake Michigan does not greatly increase the size of the area where the water table is simulated to be above land surface from the wet-weather (March 2011) simulation (fig. 46; compare with fig. 35). Some increase occurs in the northernmost parts of the active model area closest to Lake Michigan and in the wetland areas south of US-12 on the east side of County Line Road. The increase in water-table altitude in the western quarter of the model area that includes parts of Gary south of the Grand Calumet lagoons are most likely underestimated. This underestimation is due to the value of the constant-head boundary condition in the model that represents the Grand Calumet lagoons being set equal to the observed wet-weather hydraulic conditions in March 2011, which are most likely lower than the lake level for May 31, 1998. No water-level data are available for the lagoons on May 31, 1998. Simulated discharge from US-12 ditch increased 9.6 percent (about $0.06 \mathrm{ft}^{3} / \mathrm{s}$ or $36,000 \mathrm{gal} / \mathrm{d}$ ) from the values simulated in the wet-weather simulation. 


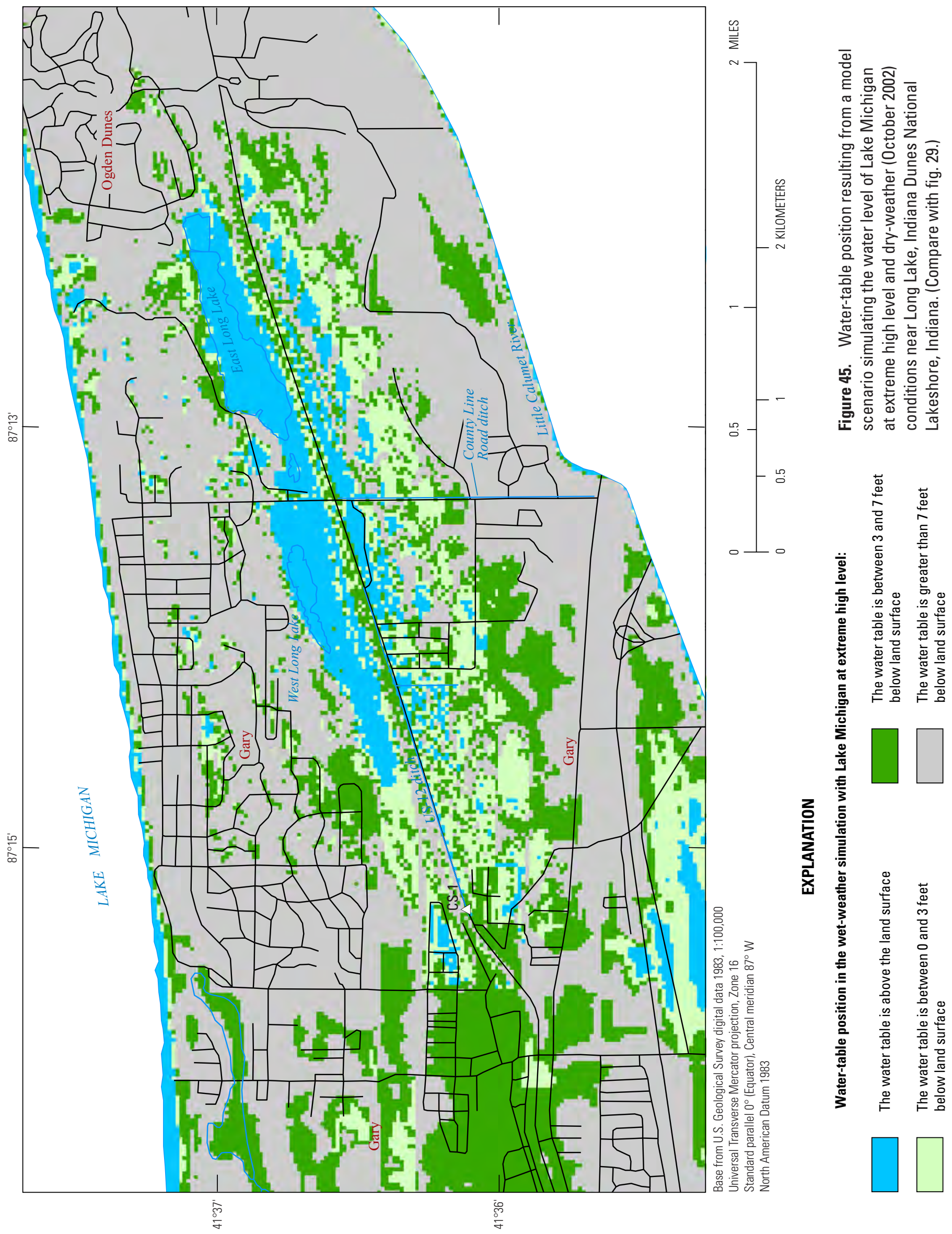



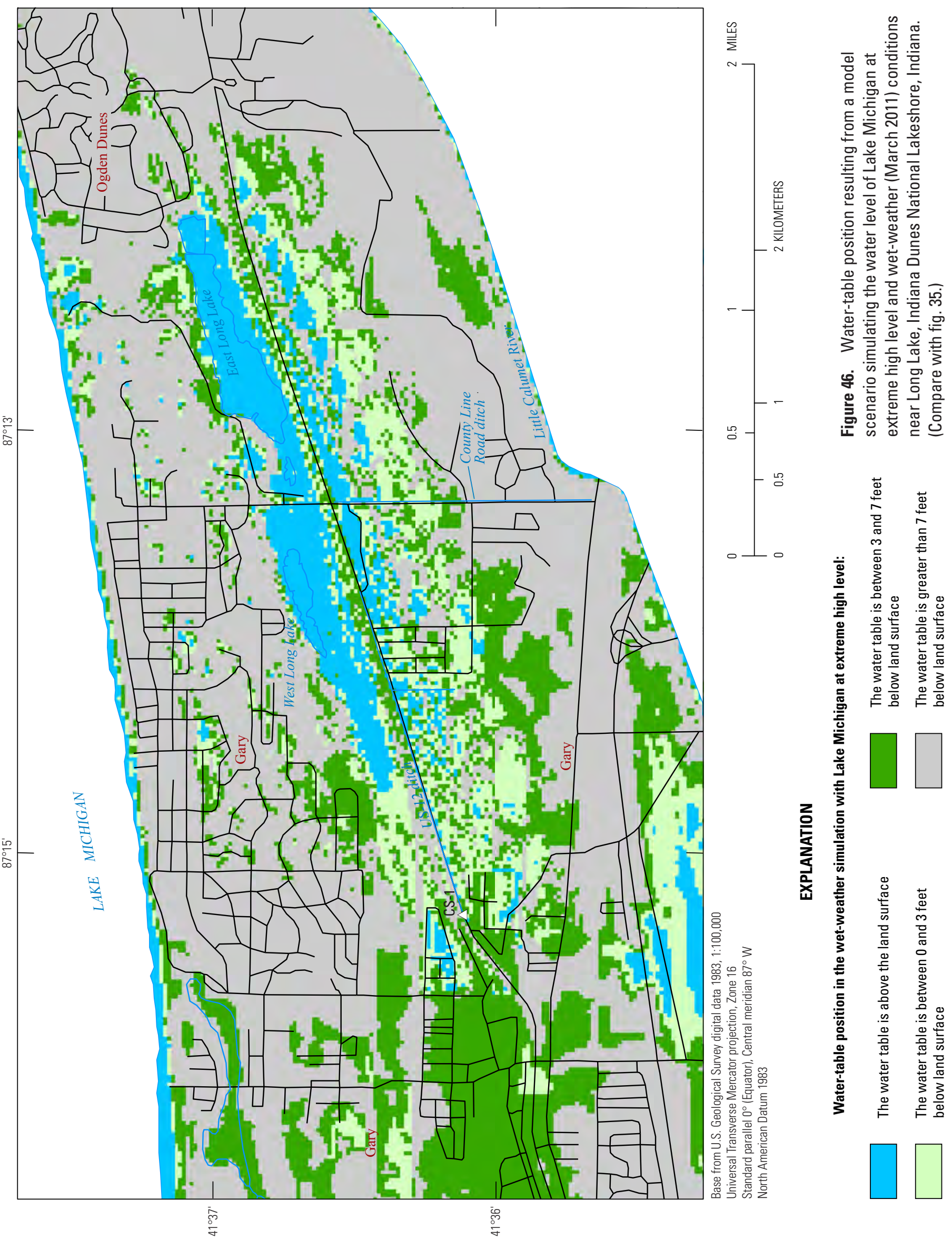


\section{Simulated Decrease in Level of Lake Michigan}

A scenario simulating the decrease in the level of Lake Michigan was run on both the calibrated dry-weather (October 2002) model and the wet-weather (March 2011) simulation to estimate the effects on simulated hydrology in the modeled area. In order to perform the simulation, the constant-head boundary condition that represents Lake Michigan along the northern part of the model (fig. 20) was set equal to the extreme low level of $575.14 \mathrm{ft}$ above NAVD 88 recorded on December 23, 2007, at the NOAA Lake Michigan monitoring site at Calumet Harbor, Ill. (period of record March 12, 1905, through September 8, 2011), a decrease of $3.52 \mathrm{ft}$ for the October 2002 model and $2.56 \mathrm{ft}$ for the March 2011 simulation. No other parameter values or model input values were changed from those presented earlier in the report.

\section{Dry-Weather (October 2002) Simulation}

The decrease of the level of Lake Michigan had little effect on the size of the area where the water table is simulated to be above land surface, and it affected the area where the water table reaches within $7 \mathrm{ft}$ of the land surface only in the areas south of the Grand Calumet lagoons in Gary (fig. 47; compare with fig. 29). These changes can most likely be explained by the value of the constant-head boundary condition in the model that represents the Grand Calumet lagoons being set equal to the observed conditions in October 2002, which are higher than the December 23, 2007, Lake Michigan level. No water-level data are available for the lagoons on December 23, 2007. Simulated discharge from US-12 ditch decreased 7.4 percent (about $0.02 \mathrm{ft}^{3} / \mathrm{s}$ or $15,000 \mathrm{gal} / \mathrm{d}$ ) from the values simulated in the calibrated dry-weather (October 2002) model.

\section{Wet-Weather (March 2011) Simulation}

The decrease of the level of Lake Michigan little affected the size of the area where the water table is simulated to be above land surface (fig. 48; compare with fig. 35). The decrease in inundated area occurs in areas to the south of East Long Lake, west of West Long Lake, and the wetland areas to the south of US-12. The change in water-table altitude in the western quarter of the model area that includes parts of Gary south of the Grand Calumet lagoons is most likely underestimated. This underestimation is due to the value of the constant-head boundary condition in the model that represents the Grand Calumet lagoons being set equal to the wet-weather observed conditions in March 2011, which are lower than the December 23, 2007, Lake Michigan level. No water-level data are available for the lagoons on December 23, 2007. Simulated discharge from US-12 ditch decreased 3.1 percent (about $0.02 \mathrm{ft}^{3} / \mathrm{s}$ or $12,000 \mathrm{gal} / \mathrm{d}$ ) from the values simulated in the wet-weather March 2011 simulation. 

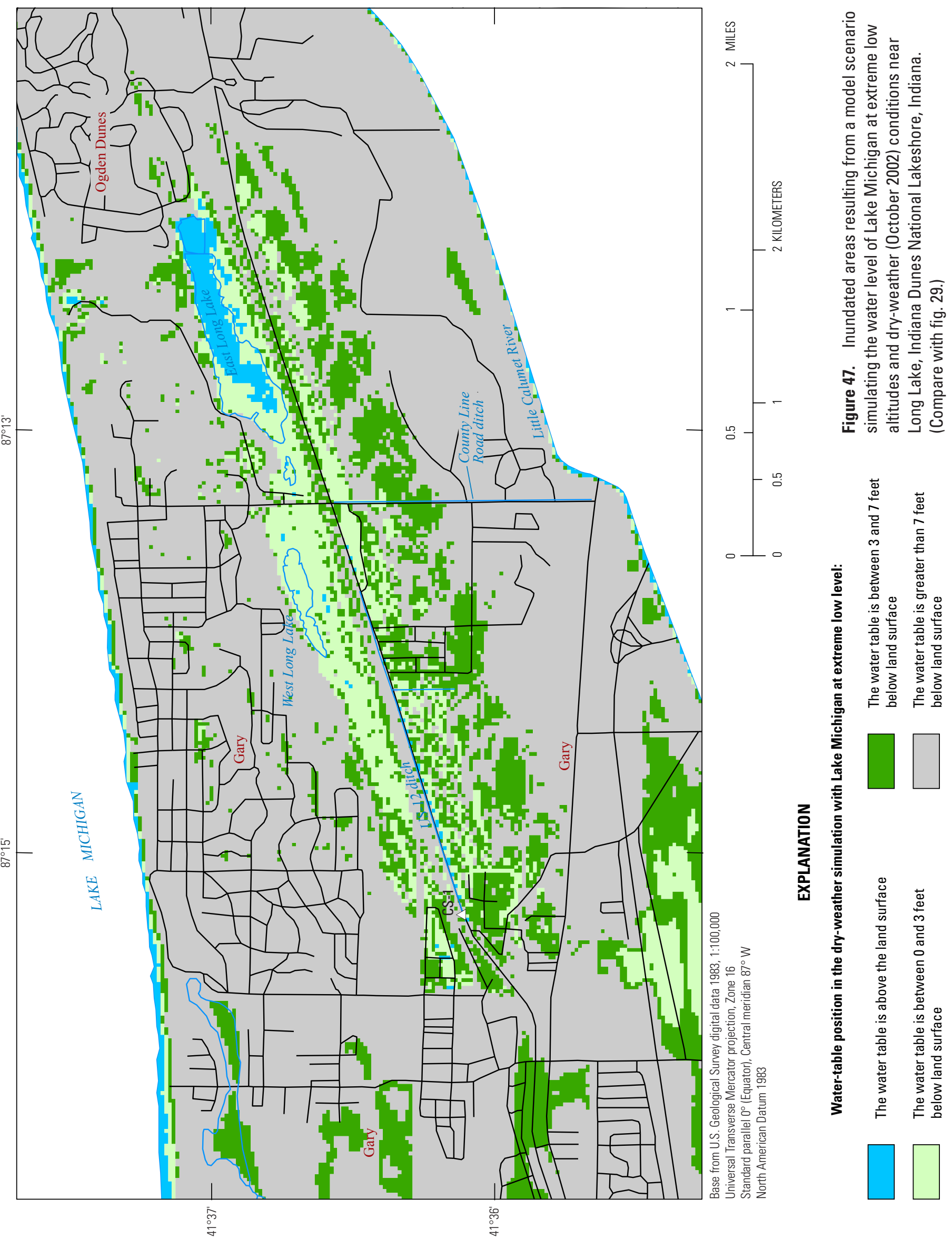


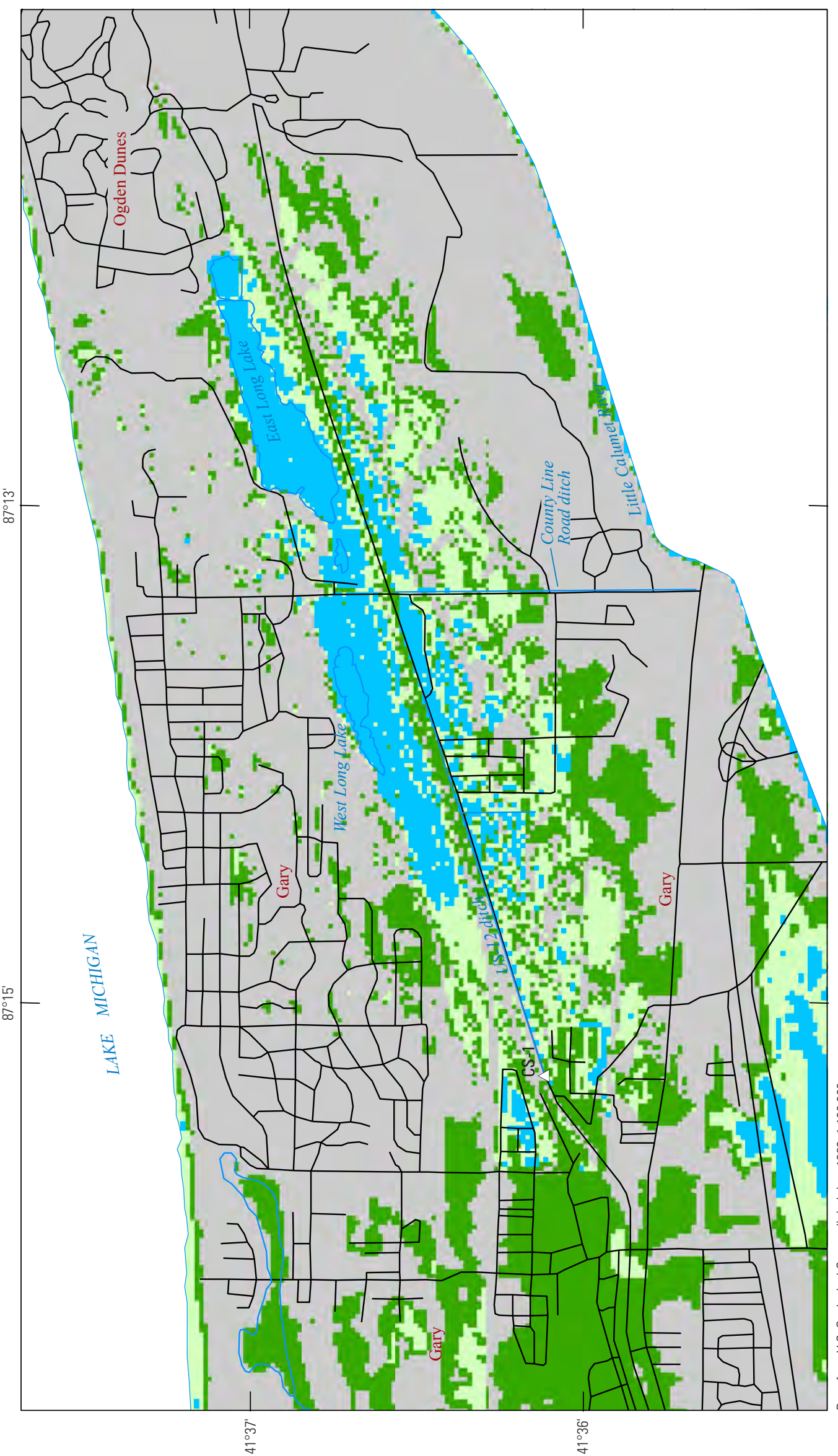

岂

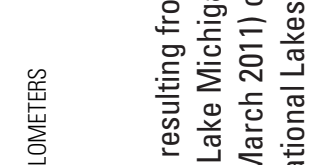

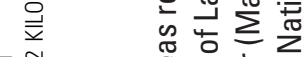

覀

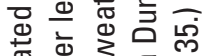

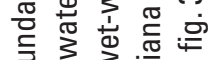

至尘 3

过. 它

인 $\frac{\pi}{1}$

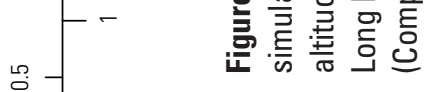
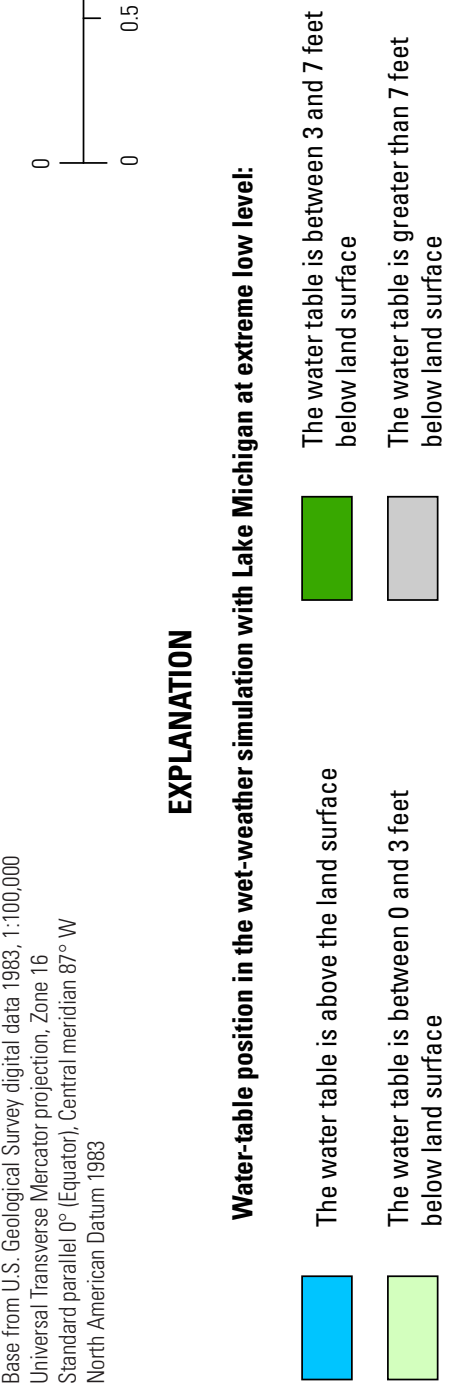


\section{Discharge From US-12 Ditch as Simulated in All Scenarios}

Table 17 provides the simulated values of discharge in US-12 ditch for the calibrated dry-weather condition model, the wet-weather condition simulation and the simulated scenarios. For all simulated scenarios using the dry-weather condition model, the scenario simulating the increase in elevation by four feet of a weir plate at the control structure where discharge from the US-12 ditch enters the GSD sewer decreased the flow in US-12 ditch the most (61.9\%). For all simulated scenarios using the wet-weather condition model, the scenario simulating the effects of applying a constant slope along County Line Road ditch from it northernmost point near US-12 to its discharge point at the Little Calumet River decreased the flow in US-12 ditch the most (24.4\%).

Table 17. Simulated values of discharge and percent difference in discharge from US-12 ditch for the simulations included in this report.

[NA, not applicable; $\mathrm{ft}^{3} / \mathrm{s}$, cubic feet per second; Mgal/d, million gallons per day; \%, percent]

\begin{tabular}{|c|c|c|c|c|c|}
\hline Parent model & Scenario & $\begin{array}{l}\text { Discharge from } \\
\text { US-12 ditch } \\
\left.\text { (ft } \mathrm{ft}^{3} / \mathrm{s}\right)\end{array}$ & $\begin{array}{l}\text { Discharge from } \\
\text { US-12 ditch } \\
\text { (Mgal/d) }\end{array}$ & $\begin{array}{l}\text { Simulated } \\
\text { difference in } \\
\text { discharge from } \\
\text { US-12 ditch } \\
\text { (Mgal/d) }\end{array}$ & $\begin{array}{l}\text { Percent } \\
\text { change }\end{array}$ \\
\hline Dry weather (October 2002) & & 0.31 & 0.200 & NA & NA \\
\hline Dry weather (October 2002) & $\begin{array}{l}\text { Decrease Lake Michigan level to } \\
\text { historical low water level }\end{array}$ & 0.287 & 0.186 & -0.015 & $-7.4 \%$ \\
\hline Dry weather (October 2002) & Discontinue use of filtration pond & 0.303 & 0.196 & -0.005 & $-2.3 \%$ \\
\hline Dry weather (October 2002) & $\begin{array}{l}\text { Discontinue discharge from US-12 ditch } \\
\text { into sanitary sewer system }\end{array}$ & NA & NA & NA & NA \\
\hline Wet weather (March 2011) & & 0.585 & 0.378 & NA & NA \\
\hline Wet weather (March 2011) & Connect East and West Long Lake & NA & NA & NA & NA \\
\hline Wet weather (March 2011) & Deepen County Line Road ditch & 0.442 & 0.286 & -0.092 & $-24.4 \%$ \\
\hline Wet weather (March 2011) & $\begin{array}{l}\text { Increase Lake Michigan level to } \\
\text { historical high water level }\end{array}$ & 0.641 & 0.414 & 0.036 & $9.6 \%$ \\
\hline Wet weather (March 2011) & $\begin{array}{l}\text { Decrease Lake Michigan level to } \\
\text { historical low water level }\end{array}$ & 0.567 & 0.367 & -0.012 & $-3.1 \%$ \\
\hline Wet weather (March 2011) & $\begin{array}{l}\text { Discontinue discharge from US-12 ditch } \\
\text { into sanitary sewer system }\end{array}$ & NA & NA & NA & NA \\
\hline
\end{tabular}




\section{Model Limitations and Qualifications}

Predictive simulations by the groundwater model should be evaluated and qualified on the basis of model reliability (Anderson and Woessner, 1992, p. 284). The reliability of the calibration is dependent upon the assumptions used in construction of the model and the adequacy of the observations used in the calibration. The simplifying assumptions used in the development of this model were previously discussed. Although these assumptions were in some ways tested and described within this report, more data may be required to fully evaluate these and other assumptions. The following factors should be considered when evaluating this model and any predictive simulations that this model may produce:

1. In order to simulate ponding of water on the land surface, the model was constructed with model layer 1 representing open water with horizontal and vertical hydraulic conductivity values of $7,000 \mathrm{ft} / \mathrm{d}$. The accuracy of simulating volumes of open water in a model is directly related to the ability of using large values of hydraulic conductivity. The numerical solution of this groundwater flow model became unstable with values greater than $7,000 \mathrm{ft} / \mathrm{d}$. Although this value does not represent the ability of water to move without resistance, it is an adequate representation for this simulation. At the point where the water table rises above land surface, surface runoff should be generated. Because of this, the actual area where water levels rise above ground surface may be smaller than the area shown in the figure even though the amount of surface runoff is estimated to be small, owing to the high permeability of the materials at land surface.

2. Figures displaying inundated areas were calculated by using the altitude of the simulated, steady-state water table and land-surface elevation datasets with resolution of $98.4 \mathrm{ft}(30 \mathrm{~m})$ and $9.8 \mathrm{ft}(3 \mathrm{~m})$. Uncertainty of the displayed area of inundation is made up of both the overall fit of the groundwater flow model and inaccuracies of the land-surface altitudes or resolution of the land-surface elevation dataset.

3. The model is best used to simulate groundwater flow in the surficial sand aquifer surrounding East Long Lake and West Long Lake because almost all of the observations used to calibrate the model are from the surficial sand aquifer simulated by layer 2 . The simulated water-table distributions and groundwater flow paths are considered to be more accurate near the areas surrounding East Long Lake and West Long Lake than in areas with fewer observations.

4. Direct measures of recharge rates to the simulated deposits were not possible. Initial estimates of recharge were taken from investigations in similar areas with a similar makeup of materials. Automated parameter estimation and manual calibration techniques were used to derive final values for recharge for the groundwater flow model.
5. The model was constructed by use of two layers to represent the surficial aquifer in the modeled area. Initial efforts were made to include additional model layers that would simulate the finer grained muck deposits in wetland areas and a leaky confining unit that may underlie parts of the modeled area. Model parameters that were included to represent these features were found to be insensitive during the model calibration process, so they were removed. Additional data collection and its inclusion into the model-calibration process might have affected the sensitivity of these parameters and their inclusion in the simulations.

\section{Summary and Conclusions}

A steady-state three-layer computer model consisting of 114 rows and 409 columns was constructed and calibrated to a dry-weather (October 2002) hydrologic condition to simulate flow through the surficial aquifer and the interaction between hydrologic features around East Long Lake and West Long Lake in the Indiana Dunes National Lakeshore. The top layer simulated water bodies by using a high hydraulic conductivity of $7,000 \mathrm{ft} / \mathrm{d}$, and the remaining two layers simulated the majority of the surficial sand aquifer.

Differences between the water-level data collected during the dry-weather (October 2002) and wet-weather (March 2011) conditions indicate that East Long Lake functioned as an area of groundwater recharge in October 2002, as described by Isiorho and others (1996), and became more of a "flowthrough" lake in March 2011, as described by Shedlock and others (1994), with the groundwater divide south of US-12.

A detailed examination of the water levels and the bottom of the ditch along County Line Road was done to determine where debris-clogged culverts may affect the groundwater system. The results reveal a point near surface-water-level measurement site C-7 (fig. 3), the approximate southern side of the groundwater divide, where water ponds upstream in response to the buildup of vegetation and debris or the possible collapse of the culvert over the ditch (fig. 16). The survey of the elevation of the bottom of the ditch shows a sharp increase in elevation at site C-7.

Nonlinear least-squares regression was used with automated parameter estimation to determine optimum parameter values for the model. The most effective improvement to model design was to classify separate recharge areas by their dominant land use as opposed to assigning recharge rates according to individual land-use pixels. The calibrated value of hydraulic conductivity for the sand was $21.34 \mathrm{ft} / \mathrm{d}$, and recharge rates for the dry-weather model calibration varied from $-1.01 \mathrm{in} / \mathrm{yr}$ for urban areas representing leaky sewers to $7.3 \mathrm{in} / \mathrm{yr}$ for recharge in areas outside the wetland and urban areas. The mean absolute error between simulated and measured water levels is $0.52 \mathrm{ft}$, which translates into a relative 
error (based on water-level variation in the measured water levels) of 2.96 percent.

Two results from the dry-weather simulation are noteworthy: (1) The filtration pond at the east end of East Long Lake, when active, contributed approximately 10 percent of the total water entering East Long Lake. The contribution of flow to the lake from the filtration pond was nearly one-fifth that being contributed from the surficial aquifer. (2) The ditch on the east side of County Line Road had little to no effect on simulated water level.

An additional simulation was created by adjusting the calibrated dry-weather model to match surface-water and groundwater levels measured during the wet-weather (March 2011) conditions by (1) increasing recharge parameters from the calibration values to compensate for the increased amount of precipitation prior to data collection and the discontinued use of the water filtration pond east of East Long Lake, and (2) manipulating the elevation of the bottom of the drain cells that represent US-12 ditch to account for the locations and relative altitude of the four beaver dams observed during data collection. The recharge values representing the wetland and undeveloped areas of the model were increased by 4.31 and $0.8 \mathrm{in} / \mathrm{yr}$, respectively, and the recharge value representing the seepage from the filtration pond was set equal to zero.

Noteworthy results from the wet-weather March 2011 simulation include the following: (1) US-12 ditch does not receive water from East Long Lake or West Long Lake in either the wet-weather or the dry-weather simulation. The capture zone for US-12 ditch is mostly to the south of the ditch. (2) Because the filtration pond was no longer active in 2011, the interaction between the surficial aquifer, the filtration pond, and East Long Lake has greatly changed. East Long Lake contributes a small amount of water (approximately 4 percent of all water leaving East Long Lake) to the filtration pond. The major sources of water to East Long Lake are precipitation (46 percent of total) and inflow from the surficial aquifer (54 percent of total). (3) County Line Road ditch bisects the groundwater divide and creates two water-table mounds south of US-12. The simulated flow in County Line Road ditch is $0.09 \mathrm{ft}^{3} / \mathrm{s}$.

Multiple scenarios were run in order to apply certain climatic conditions and engineering controls to the calibrated groundwater flow model (table 12). The results of these scenarios will give the Gary Sanitary District (GSD), the National Park Service, and other resource managers in the area an improved understanding of the hydrology in the vicinity of Long Lake in order to understand the effects drainage alterations will make to the water levels of East and West Long Lake and to the water table in the surrounding residential areas.

Noteworthy results from the scenarios are the following:

1. In the scenario simulating the removal of the beaver dams from US-12 ditch under wet-weather (March 2011) conditions, much less of the area west of County Line Road is estimated to be inundated than in the March 2011 simulation with the dams. Simulated discharge from US-12 ditch increased 13 percent (about 50,000 gal/d) from the values in the wet-weather (March 2011) simulation.

2. In the scenario simulating the discontinued use of the water treatment filtration pond under dry-weather (October 2002) conditions, the water table was estimated to be above the land surface in only very small areas of the filtration pond and localized areas of East Long Lake, the wetlands surrounding West Long Lake, and eastern Gary. Simulated discharge from US-12 ditch decreased 2.4 percent (about 4,000 gal/d) from the values simulated with the calibrated dry-weather model.

3. In the scenario simulating the removal of discharge from US-12 ditch to the GSD sewer system, much of the low-lying area north of US-12 and surrounding West Long Lake, including residential areas in eastern Gary, was estimated to be inundated - a much greater area than simulated with the dry-weather calibrated model. The inundated area spreads further north and south into Gary in the March 2011 wet-weather simulation.

4. In the scenario simulating the increased elevation of the weir plate at the western terminus of US-12 ditch to decrease discharge to the GSD sewer system, discharge from US-12 ditch using the dry-weather model was decreased by approximately 27 and 61 percent for weirplate elevation increases of 2 and $4 \mathrm{ft}$, respectively, and, using the wet-weather simulation, by approximately 3 and 6 percent for weir-plate elevation increases of 1 and $2 \mathrm{ft}$, respectively (table 17). The area inundated by water increased to include areas surrounding the US-12 ditch and the wetlands immediately to the south and much of the area surrounding West Long Lake in the dry-weather scenario. Much of the inundated area surrounding East Long Lake and the filtration pond was unaffected. The area inundated by water in the wet-weather simulation is largely the same as simulated with the ditch in operation except for near the western terminus of US-12 ditch, where low-lying places near Gary are estimated to be inundated.

5. The simulated hydrologic connection between East Long Lake and West Long Lake resulted in local areas in Gary to the north and west of West Long Lake no longer having the water table above the land surface, owing to the somewhat lower water table on the west side of County Line Road.

6. For the scenario simulating the deepening of ditch along the east side of County Line Road, discharge from US-12 ditch decreased 26 percent and discharge from County Line Road ditch increased 100 percent from the values simulated with the calibrated dry-weather model. Simulated discharge from US-12 ditch decreased 24 percent and discharge from County Line Road ditch increased by more than 500 percent from the value in the wet-weather simulation. Deepening of the County Line Road ditch also 
decreased the altitude of the water table in the areas surrounding the ditch immediately south of the intersection of US-12 and County Line Road under both the simulated dry- and wet-weather conditions.

7. For the scenario simulating the increase of the Lake Michigan water level to the historical high of May 31, 1998, the simulated discharge from US-12 ditch increased 14.2 percent from the values simulated in the calibrated dryweather model and increased 9.6 percent from the values in the wet-weather simulation.

8. For the scenario simulating the decrease of the Lake Michigan water level to the historical low of December 23, 2007, the simulated discharge from US-12 ditch decreased 7.5 percent from the values simulated in the calibrated dry-weather model and decreased 3.1 percent from the values in the wet-weather simulation.

The results of this study can be used by water-resource managers to understand how surrounding ditches affect water levels in East and West Long Lake and area wetlands. The groundwater model developed in this study can be applied in the future to answer questions about how alterations to the drainage system in the area will affect water levels in East and West Long Lake and surrounding areas. The modeling methods developed in this study provide a template for other studies of groundwater flow and groundwater-surface water interactions within the shallow surficial aquifer in northern Indiana.

\section{References}

Alley, W.M., Reilly, T.E., and Franke, O.L., 1999, Sustainability of ground-water resources: U.S. Geological Survey Circular 1186, 79 p.

Anderson, M.P., and Woessner, W.W., 1992, Applied groundwater modeling - Simulation of flow and advective transport: San Diego, Academic Press, 381 p.

Arihood, L.D., and Cohen, D.A., 1998, Geohydrology and simulated ground-water flow in northwestern Elkhart County, Indiana: U.S. Geological Survey Water-Resources Investigations Report 97-4204, 47 p.

Banta, E.R., 2000, MODFLOW-2000, the U.S. Geological Survey modular ground-water model-Documentation of packages for simulating evapotranspiration with a segmented function (ETS1) and drains with return flow (DRT1): U.S. Geological Survey Open-File Report 00-466, $127 \mathrm{p}$.

Beaty, J.E., 1994, Water resource availability in the Lake Michigan Region, Indiana: Indiana Department of Natural Resources, Division of Water, Water Resource Assessment 94-4, 257 p.
Brennan, G.A., 1923, The wonders of the dunes: Indianapolis, Ind., Bobbs-Merrill Co., 326 p.

Brown, S.E.; Bleuer, N.K.; Dickson, M.L; Dintaman, Chris; Olejnik, Jennifer; and Rupp, R.F., 2004, Digital elevation model of Indiana-Revised: Indiana Geological Survey Open-File Study 04-01.

Buszka, P.M., Cohen, D.A., Lampe, D.C., and Pavlovic, N.B., 2011, Relation of hydrologic processes to groundwater and surface-water levels and flow directions in a dune-beach complex at Indiana Dunes National Lakeshore and Beverly Shores, Indiana: U.S. Geological Survey Scientific Investigations Report 2011-5073, 75 p.

Clement, S.E., Waggener, S., Austin, W.H., Chalifoux, O.A., and Striker, A.F., 1940, Porter Quadrangle, Indiana: U.S. Geological Survey Quadrangle Map N4130W8700/15, scale 1:62,500

Cooley, R.L., and Naff, R.L., 1990, Regression modeling of ground-water flow: U.S. Geological Survey Techniques of Water-Resources Investigations, book 3, chap. B4, 232 p.

Crawford, C.G., and Wangsness, D.J., 1987, Streamflow and water quality of the Grand Calumet River, Lake County, Indiana, and Cook County, Illinois, October 1984: U.S. Geological Survey Water- Resources Investigations Report 86-4208, 137 p.

Duwelius, R.F., Yeskis, D.J., Wilson, J.T., and Robinson, B.A., 2001, Geohydrology, water quality, and simulation of ground-water flow in the vicinity of a former waste-oil refinery near Westville, Indiana, 1997-2000: U.S. Geological Survey Water-Resources Investigations Report 01-4221, $161 \mathrm{p}$.

Fetter, C.W., 1994, Applied hydrogeology (3d ed.): New York, McMillian, $691 \mathrm{p}$

Fenelon, J.M., and Watson, L.R., 1993, Geohydrology and water quality of the Calumet aquifer, in the vicinity of the Grand Calumet River/Indiana Harbor Canal, northwestern Indiana: U.S. Geological Survey Water-Resources Investigations Report 92-4115, 151 p.

Freeze, A.R., and Cherry, J.A., 1979, Groundwater: Englewood Cliffs, N.J., Prentice-Hall, 604 p.

Gillies, D.C., and Lapham, W.W., 1980, Reassessment of the effects of construction dewatering on ground-water levels in the Cowles Unit, Indiana Dunes National Lakeshore, Indiana-Supplement to Geological Survey Water-Resources Investigations 78-138: U.S. Geological Survey Open-File Report 80-1105, 50 p.

Gray, H.H., 2000, Physiographic divisions of Indiana: Indiana Geological Survey Special Report 61, 15 p., 2 fig., 1 pl. 
Grannemann, N.J., Hunt, R.J., Nicholas, J.R. Reilly, T.E., and Winter, T.C., 2000, The importance of ground water in the Great Lakes region: U.S. Geological Survey WaterResources Investigations Report 00-4008, 14 p.

Greeman, T.K., 1995, Water levels in the Calumet aquifer and their relation to surface-water levels in northern Lake County, Indiana: U.S. Geological Survey Water-Resources Investigations Report 94-4110, 61 p.

Harbaugh, A.W., 2005, MODFLOW-2005, The U.S. Geological Survey modular ground-water model-The GroundWater Flow Process: U.S. Geological Survey Techniques and Methods, book 6, chap. A16 [variously paged].

Harbaugh, A.W., Banta, E.R., Hill, M.C., and McDonald, M.G., 2000, MODFLOW-2000, the U.S. Geological Survey modular ground-water model - User guide to modularization concepts and the Ground-Water Flow Process: U.S. Geological Survey Open-File Report 00-92, 121 p.

Hartke, E.J., Hill, J.R., and Reshkin, Mark, 1975, Environmental geology of Lake and Porter Counties, Indiana-An aid to planning: Indiana Department of Natural Resources, Geological Survey Special Report 11, Environmental Study 8, 57 p.

Hill, M.C., 1998, Methods and guidelines for effective model calibration; with application to UCODE, a computer code for universal inverse modeling, and MODFLOWP, a computer code for inverse modeling with MODFLOW: U.S. Geological Survey Water-Resources Investigations Report 98-4005, 90 p.

Hill, M.C., Banta, E.R., Harbaugh, A.W., and Anderman, E.R., 2000, MODFLOW-2000, the U.S. Geological Survey modular ground-water model-User guide to the Observation, Sensitivity, and Parameter-Estimation Processes and three post-processing programs: U.S. Geological Survey Open-File Report 00-184, 209 p.

Hill, M.C., and Tiedeman, C.R., 2007, Effective groundwater model calibration - With analysis of data, sensitivities, prediction, and uncertainty: Hoboken, N.J., John Wiley and Sons, $455 \mathrm{p}$.

Holmes, R.R., Terrio, P.J., Harris, M.A., and Mills, P.C., 2001, Introduction to field methods for hydrologic and environmental studies: U.S. Geological Survey Open-File Report 01-05, $241 \mathrm{p}$.

Indiana Department of Natural Resources, 2002, Water well record database - Digital data, 2002: Division of Water, Water Rights and Use Section, accessed July 14, 2010, at http://www.in.gov/dnr/water/3595.htm.
Isiorho, S.A., Beeching, F.M., Stewart, P.M., and Whitman, R.L., 1996, Seepage measurements from Long Lake, Indiana Dunes National Lakeshore: Environmental Geology, v. 28, p. 99-105.

Kay, R.T., Duwelius, R.F., Brown, T.A., Micke, F.A., and Witt-Smith, C.A., 1996, Geohydrology, water levels and directions of flow, and occurrence of light-nonaqueousphase liquids on ground water in northwestern Indiana and the Lake Calumet area of northeastern Illinois: U.S. Geological Survey Water-Resources Investigations Report 95-4253, $84 \mathrm{p}$.

Lohman, S.W., and others, 1972, Definitions of selected ground-water terms - Revisions and conceptual refinements: U.S. Geological Survey Water-Supply Paper 1988, $21 \mathrm{p}$.

Malott, C.A., 1922, The physiography of Indiana, in Handbook of Indiana geology: Indiana Department of Conservation Publication 21, part 2, p. 59-256.

Marie, J.R., 1976, Model analysis of effects on water levels at Indiana Dunes National Lakeshore caused by construction dewatering: U.S. Geological Survey Water-Resources Investigations Report 76-82, 32 p.

McDonald, M.G., and Harbaugh, A.W., 1988, A modular three-dimensional finite-difference ground-water flow model: U.S. Geological Survey Techniques of WaterResources Investigations, book 6, chap. A1, 586 p.

Meyer, W.R., and Tucci, Patrick, 1979, Effects of seepage from fly-ash settling ponds and construction dewatering on groundwater levels in the Cowles Unit, Indiana Dunes National Lakeshore, Indiana: U.S. Geological Survey Water-Resources Investigations 78-138, 95 p.

Midwestern Regional Climate Center, 2010, Products and services-Online data-MACS, accessed May 11, 2010, at http://mcc.sws.uiuc.edu/prod_serv/prodserv.htm.

Moore, P.A., 1959, The Calumet Region, Indiana's last frontier: Indiana Historical Bureau, Indiana Historical Collections, v. 39, 685 p.

Morlock, S.E., Nguyen, H.T., and Majors, D.K., 2004, Water resources data, Indiana, water year 2003: U.S. Geological Survey Water-Data Report IN-03-1,610 p.

Mulcare, D.M., 2004, NGS Toolkit, Part 9-The National Geodetic Survey VERTCON Tool: Professional Surveyor, March 2004, v. 24, no. 3, 3 p., accessed March 2, 2012, at http://www.ngs.noaa.gov/TOOLS/Vertcon/vertcon.html.

National Oceanic and Atmospheric Administration, 1982, Monthly normals of temperature and precipitation, heating and cooling degree days, 1951-80, Indiana: National Oceanic and Atmospheric Administration, Climatography of the United States no. 81, p.13. 
National Oceanic and Atmospheric Administration, 1986-87, Climatological data, Indiana: v. 91-93 (published monthly).

National Oceanic and Atmospheric Administration, 2011, Verified daily mean water level data-9087044 Calumet Harbor, Lake Michigan, IL from 20021016 to 20021016 and 20110308 to 20110308, accessed September 8, 2011, at http://co-ops.nos.noaa.gov/data_res.html to http:// www.co-ops.nos.noaa.gov/data_retrieve.shtml?input_ code $=10011111 \mathrm{vgl}$.

Niswonger, R.G., Panday, Sorab, and Ibaraki, Motomu, 2011, MODFLOW-NWT, A Newton formulation for MODFLOW-2005: U.S. Geological Survey Techniques and Methods, book 6, chap. A37, 44 p.

Poeter, E.P., Hill, M.C., Banta, E.R., Mehl, Steffen, and Christensen, Steen, 2005, UCODE_2005 and six other computer codes for universal sensitivity analysis, calibration, and uncertainty evaluation: U.S. Geological Survey Techniques and Methods, book 6, chap. A11, 283 p.

Pollock, D.W., 2012, User guide for MODPATH version 6-A particle-tracking model for MODFLOW: U.S. Geological Survey Techniques and Methods, book 6, chap. A41, $58 \mathrm{p}$.

Rosenshein, J.S., and Hunn, J.D., 1968, Geohydrology and ground-water potential of Lake County, Indiana: Indiana Department of Conservation, Division of Water Resources Bulletin 31, $36 \mathrm{p}$.

Shedlock, R.J., Cohen, D.A., Imbrigiotta, T.E., and Thompson, T.A., 1994, Hydrogeology and hydrochemistry of dunes and wetland along the southern shore of Lake Michigan, Indiana: U.S. Geological Survey Open-File Report 92-139, $85 \mathrm{p}$.

Shedlock, R.J., and Harkness, W.E., 1984, Shallow groundwater flow and drainage characteristics of the Brown Ditch basin near the East Unit, Indiana Dunes National Lakeshore, Indiana, 1982: U.S. Geological Survey Water-Resources Investigations Report 83-4271, 37 p.
Thompson, T.A., 1987, Sedimentology, internal architecture and depositional history of the Indiana Dunes National Lakeshore and State Park: Bloomington, Ind., Indiana University, unpublished Ph.D. thesis, $129 \mathrm{p}$.

Thompson, T.A., 1992, Beach ridge development and lakelevel variation in southern Lake Michigan: Sedimentary Geology, v. 80, p. 305-318.

U.S. Army Corps of Engineers, 1902, Map showing Calumet River district, Ill. \& Ind.: 1 sheet, scale 1 inch $=1$ mile.

U.S. Census Bureau, 2010, United States Census 2010 interactive population map, accessed August 1, 2012, at http://2010.census.gov/2010census/popmap/.

U.S. Geological Survey, 1966, Topographic instructions of the United States Geological Survey-Leveling: U.S. Geological Survey Topographic Instructions, chaps, 2E1-2E5, 63 p.

U.S. Geological Survey, 2011, National Water Information System, Web Interface-USGS 04095090 Burns Ditch at Portage, IN, accessed December 9, 2011, at http:// waterdata.usgs.gov/nwis/nwisman/?site_no $=04095090$.

Watson, L.R., Shedlock, R.J., Banaszak, K.J., Arihood, L.D. and Doss, P.K. 1989, Preliminary analysis of the shallow ground-water system in the vicinity of the Grand Calumet River/Indiana Harbor Canal, northwestern Indiana: U.S. Geological Survey Open-File Report 88-492, 45 p.

Warzyn Engineering, Inc., 1987, Agency review draft, remedial investigation report, Ninth Avenue Dump, Gary, Indiana: Omaha, Nebr., U.S. Army Corps of Engineers, Contract No. DACW 45-86-C-0002, acting for U.S. Environmental Protection Agency [variously paged]. 



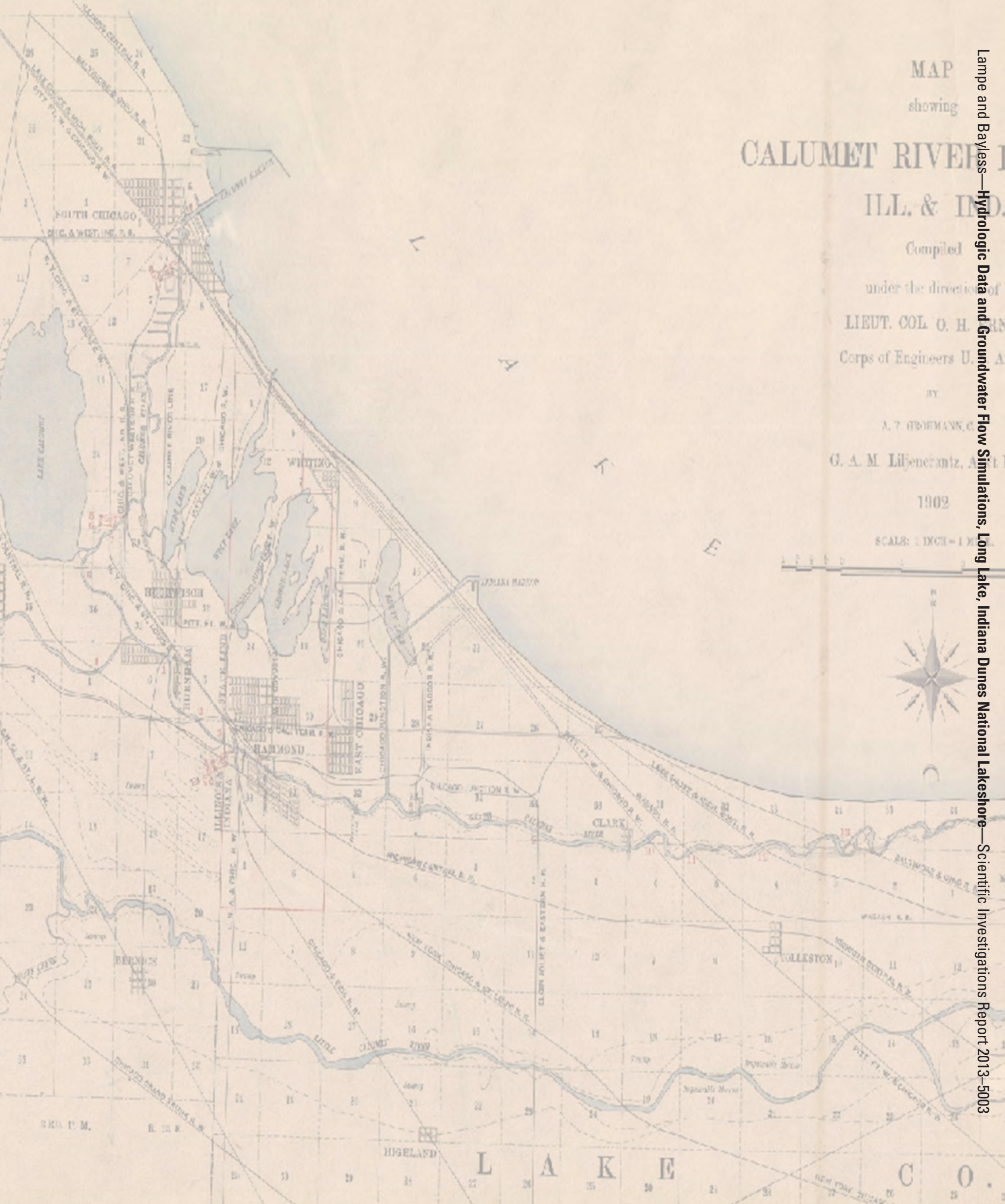

